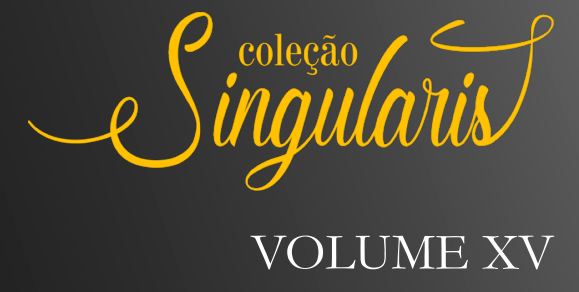

LER E ESCREVER, SENDO MULHER ANDRÉA CORREA PARAÍSO MÜLLER ROSANGELA SCHARDONG RENÉ ALDO VIJARRA (ORGS.)

$\frac{\text { Oexto e Contexta }}{\text { EDITORA E LIVRARIA }}$ 


\author{
Andréa Correa Paraíso Müller \\ Rosangela Schardong \\ René Aldo Vijarra \\ (organizadores)
}

LER E ESCREVER, SENDO MULHER

$\frac{\text { Sexta e Rontexta }}{\text { EDITORA }}$ 
C2021 Andréa Correa Paraíso Müller, Rosangela Schardong, René Aldo Vijarra

Todos os direitos reservados aos organizadores

Capa: Dyego Marçal

Diagramação e projeto gráfico: Texto e Contexto

Supervisão Editorial: Rosangela Schardong

Revisão: Rosangela Schardong, Andréa Correa Paraíso

Müller, René Aldo Vijarra

L614

Ler e escrever, sendo mulheres/ Organizado por Andréa Correa Paraíso Müller; Rosangela Schardong; René Aldo Vijarra. Ponta Grossa: Texto e Contexto, 2021. (Coleção Singularis, v. 15).

$268 \mathrm{p}$.

Doi:10.54176/TVUH9307

ISBN coleção: 967-65-990049-4-0

ISBN volume: 978-65-88641-55-6

1. Produção literária - mulher. 2. Literatura - mulheres. 3. Mulheres - papel social. I. Müller, Andréa Correa Paraíso (Org.). II. Schardong, Rosangela (Org.). III. Vijarra, René Aldo (Org.). IV. T.

CDD: 808

Ficha Catalográfica Elaborada por Maria Luzia F. B. dos Santos CRB 9/986

O conteúdo dos artigos é de responsabilidade dos autores.

Não é permitida a venda total ou parcial desta obra

Texto e Gontexto

EDITORA

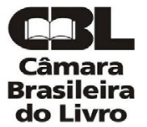

Rua Eduardo Bonjean, 375.

Uvaranas. Ponta Grossa/PR

(42) 988834226

www.textoecontextoeditora.com.br contato@textoecontextoeditora.com.br

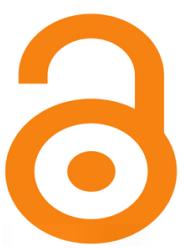


CONSELHO EDITORIAL:

Presidente:

Dra ${ }^{\mathrm{a}}$ Larissa de Cássia Antunes Ribeiro (Unicentro)

Membros:

Dr. Fábio Augusto Steyer (UEPG) Dra . Silvana Oliveira (UEPG)

Doutorando Anderson Pedro Laurindo (UTFPR)

Drª Marly Catarina Soares (UEPG)

Dr $^{\mathrm{a}}$. Naira de Almeida Nascimento (UTFPR)

Dr ${ }^{\mathrm{a}}$ Letícia Fraga (UEPG)

Dr ${ }^{\mathrm{a}}$. Anna Stegh Camati (UNIANDRADE)

Dr. Evanir Pavloski (UEPG)

$\mathrm{Dr}^{\mathrm{a}}$. Eunice de Morais (UEPG)

Dr $^{\mathrm{a}}$. Joice Beatriz da Costa (UFFS)

Dr $^{\mathrm{a}}$. Luana Teixeira Porto (URI)

Dr. César Augusto Queirós (UFAM)

Dr. Valdir Prigol (UFFS)

Dra . Clarisse Ismério (URCAMP)

Dr. Nei Alberto Salles Filho (UEPG)

$D^{2}{ }^{a}$ Ana Flávia Braun Vieira (UEPG)

Dr. Marcos Pereira dos Santos (UTFPR) 


\title{
SUMÁRIO
}

\author{
08 \\ Prólogo Caleidoscópico
}

Cap 1 - pág. 19

QUEM TEM MEDO DE EMA BOVARY?

IMAGINÁRIO, RECOMENDAÇÕES E DEMANDAS SOBRE A

FORMAÇÃO DA MULHER LEITORA

Rosangela Schardong

Doi: https://doi.org/10.54176/NMJO1115

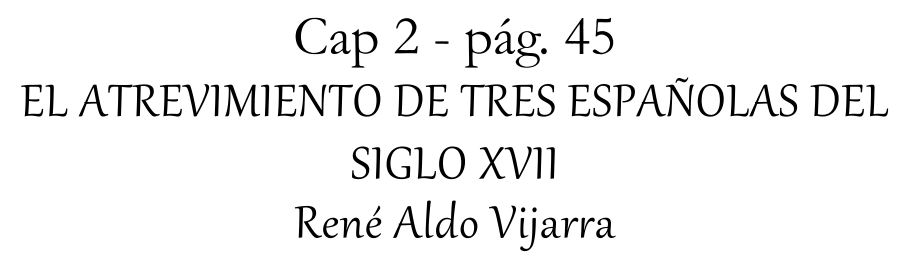

Doi: https://doi.org/10.54176/RBDH7486

Cap 3 - pág. 75

A IMAGEM DEJANE AUSTEN EM BIOGRAFIAS DO SÉCULO XIX

Daiane da Silva Lourenço

Doi: https://doi.org/10.54176/VGZF8690 


$$
\text { Cap } 4 \text { - pág. } 99
$$

O ROMANCE SOB SUSPEITA: "MADAME BOVARY", DE GUSTAVE FLAUBERT Midori Nancy Arasaki Chang

Doi: https://doi.org/10.54176/RTRI7992

$$
\begin{gathered}
\text { Cap } 5 \text { - pág. } 119 \\
\text { UM “CANTINHO” PARA AS “AMÁVEIS LEITORAS": }
\end{gathered}
$$

DISCURSOS SOBRE A MULHER NA REVISTA POPULAR

$$
\text { (1859-1862) }
$$

Andréa Correa Paraiso Müller

Doi: https://doi.org/10.54176/MQPU3242

$$
\begin{aligned}
& \text { Cap } 6 \text { - pág. } 153 \\
& \text { “TIL” - ÀS LEITORAS! }
\end{aligned}
$$

Larissa de Cássia Antunes Ribeiro

Doi: https://doi.org/10.54176/HMOO8070

$$
\text { Cap } 7 \text { - pág. } 178
$$

ALÉM DAS PÁGINAS DE QUERIDA:

AS REPRESENTAÇÕES DE FEMINILIDADE PRESENTES NA

REVISTA QUERIDA E A MEMÓRIA DE SUAS LEITORAS

IRATIENSES DURANTE A DÉCADA DE 1960

Cibeli Grochoski

Doi: https://doi.org/10.54176/JJLC8160 


\title{
Cap 8 - pág. 207 \\ MULHERES GENIAIS: A MULHER E A PRODUÇÃO DO SABER A PARTIR DO OLHAR DE MONTSERRAT ROIG \\ Kátia Aparecida da Silva Oliveira \\ Doi: https://doi.org/10.54176/GGVN4808
}

$$
\text { Cap } 9 \text { - pág. } 239
$$

LA MUJER QUE SE LEE EN “A COSTA DOS MURMÚRIOS” DE LÍDIA JORGE Adriana Esther Suarez

Doi: https://doi.org/10.54176/WWXJ8074

\author{
Pág. 265 \\ SOBRE OS AUTORES
}




\section{Prefácio Caleidoscópico}

Escrita e saber estiveram, em geral, ligados ao poder e funcionaram como forma de dominação ao descreverem modos de socialização, papéis sociais e até sentimentos esperados em determinadas situações.

Norma Telles ${ }^{1}$

Os homens eram bastante dependentes da imagem que suas mulheres pudessem traduzir para o restante das pessoas de seu grupo de convívio. Em outras palavras, significavam um capital simbólico importante, embora a autoridade familiar se mantivesse em mãos masculinas, do pai ou do marido. Esposas, tias, filhas, irmãs, sobrinhas (e serviçais) cuidavam da imagem do homem público.

Maria Ângela D'Incao ${ }^{2}$

A alusão ao caleidoscópio justifica-se por sua capacidade de "produzir um número infinito de combinações de imagens de cores variegadas", como define o Dicionário Aurélio ${ }^{3}$. Talvez o efeito deste pequeno jogo ótico de espelhos, que fascina crianças e adultos, defina bem o processo da leitura,

1. TELLES, Norma. Escritoras, escritas, escrituras (in: DEL PRIORE, Mary (org.); BASSANEZI, Carla (coord. de textos). História das mulheres no Brasil. 2. ed. São Paulo: Contexto, 1997, p. 401-442), p. 401-402.

2. D'INCAO, Maria Ângela. Mulher e família burguesa (in: DEL PRIORE, Mary, op. cit., 1997, p. 223-240), p. 229.

3. FERREIRA, Aurélio Buarque de Holanda. Novo Dicionário Aurélio da Lingua Portuguesa. 2. ed. revista e aumentada. Rio de Janeiro: Nova Fronteira, 1986, p. 321. 
sempre múltiple, em conformidade com o olhar daqueles que cobrem de sentido, de razão e de emoção as pequenas letras negras impressas sobre o papel branco. Quiséramos que a leitura deste prefácio e do livro produzisse o mesmo efeito que um caleidoscópio no ânimo das leitoras e leitores, captando a atenção pelas muitas imagens e discursos, variegadas perspectivas teóricas e de análise aqui reunidas.

Inicialmente, para abordar os temas centrais de Ler e escrever, sendo mulher, é importante considerar que, desde a Antiguidade romana, havia leis para controlar a leitura e a escrita das mulheres. Como uma precaução contra o adultério, o Concílio de Elvira, no princípio do século $\mathrm{IV}$, proíbe que as mulheres recebam diretamente uma correspondência ou a enviem sem a "terem submetido a seu marido”, assinala Aline Rousselle 4 . Há, portanto, uma longa e histórica tradição dos discursos e práticas socioculturais mobilizados para construir a submissão das mulheres aos homens, pela limitação do acesso ao conhecimento e à palavra. Exemplo disto é que, na Antiguidade romana, era questão de debate se as mulheres tinham, ou não, capacidade para receber educação. Neste contexto, Musônio Rufo, filósofo estoico (Roma, séc. I), afirmava que "as mulheres receberam dos deuses a mesma razão que os homens, a mesma disposição natural para a virtude", por isso poderiam dedicar-se à filosofia intelectual e às técnicas de pensamento ${ }^{5}$. No século III, Clemente de Alexandria repetia a mesma convicção ${ }^{6}$, porém, estas foram vozes dissonantes.

4. ROUSSELLE, Aline. A política dos corpos: entre procriação e continência em

Roma (in: DUBY, Georges; PERROT, Michele. Historia das mulheres no Ocidente (v.1). A Antiguidade. Tradução portuguesa de Maria Helena da Cruz Coelho et. al. Porto: Afrontamento, 1990, p.351-407), p. 399.

5. Apud ROUSSELLE, 1990, p. 392.

6. ROUSSELLE, 1990, p. 400. 
Não só as classes dominantes louvavam a castidade como a principal virtude das mulheres ${ }^{7}$, por este motivo as mulheres da aristocracia eram educadas para a contenção, por meio do "comedimento de gestos e de palavras, moderação do olhar", sendo alfabetizadas em casa, pela família.

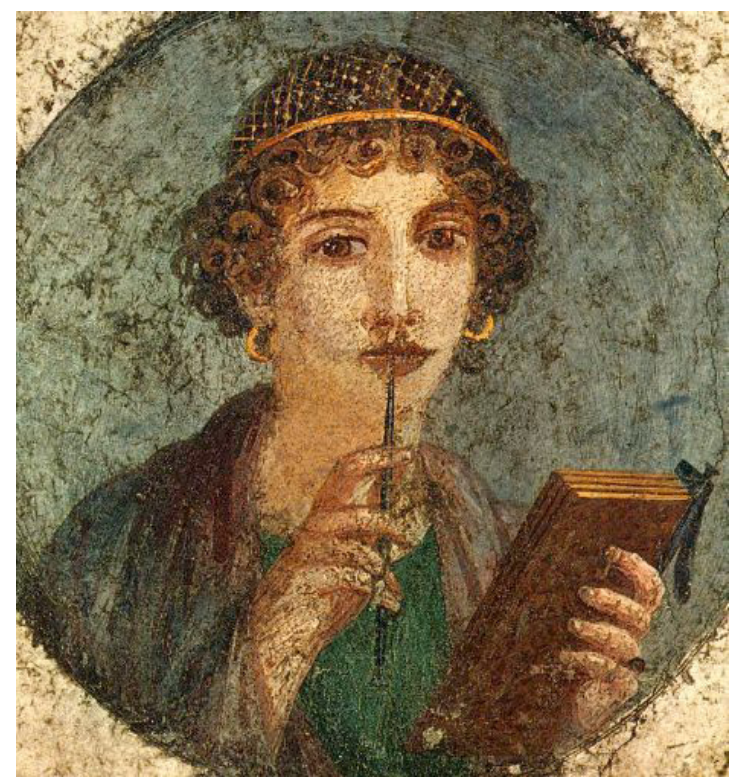

Figura 1 - Retrato de mulher da elite de Pompéia, na Antiguidade romana (s. I d. C.), que segura nas mãos tabuinhas de cera e um estilete para escrever. Segundo Rousselle, trata-se de uma pintura de Pompeius, do acervo do Museu Arqueológico Nacional de Nápoles (1990, p. 399). Disponível em: http://papelmarcante.blogspot.com/2011/07/ Acesso em: 8 jul 2021.

Contudo, também houve célebres mulheres da Antiguidade clássica elogiadas por sua inteligência e dedicação às letras, como Pola Argentária, esposa do poeta Lucano; Eudóxia Augusta, filha do filósofo Leôncio e esposa do imperador Teodósio II; Zenóbia, rainha de Palmira.

7. Ibidem, p. 386.

8. Ibidem, p. 385. 
Estes nomes fazem parte de lista de mulheres evocada por Maria de Zayas y Sotomayor, na Espanha do século XVII, no prólogo às Novelas amorosas y ejemplares (1637), a fim de autorizar sua capacidade intelectual para escrever e publicar um livro, "siendo mujer, que en opinión de algunos necios es lo mismo que una cosa incapaz" ". A audaciosa autora, raríssima pluma feminina entre os grandes nomes do Século de Ouro espanhol, dirá que não é por falta de entendimento que as mulheres não se destacam nas letras, mas por falta de professores e de livros. Em seus contos as protagonistas femininas sabem ler e escrever, desconstroem lugares comuns sobre a inferioridade intelectual e moral das mulheres, denunciando que estes são constructos culturais empregados para justificar a subordinação das mulheres aos homens.

No Ocidente, pode-se considerar que serão os ideais do Iluminismo e suas reverberações, ao longo dos séculos XVIII e XIX, que irão recomendar a ampliação da educação dada às mulheres, bem como a sistematização da educação das crianças e das classes populares, para expandir a civilidade das nações.

Com o desenvolvimento das cidades e da vida burguesa, no século XIX, na Europa e no continente americano, as salas de visita e os salões - espaços intermediários entre o lar e rua - abriam-se para saraus noturnos, jantares e festas em que se liam trechos de poesia e romances em voz alta. Nestes espaços, estima-se a demonstração de educação para as letras e os dotes musicais nas mulheres. Nestes eventos sociais, vigiadas pelos pais e maridos, elas se expõem à avaliação e à

9. Prólogo. In: ZAYAS Y SOTOMAYOR, María de. Novelas amorosas y ejemplares. Edição, introdução e notas de Julián Olivares. Madri: Cátedra, 2000, p. 159. Esta obra está disponível on-line. Recomenda-se a excelente edição de Enrique Suárez Figaredo:

https://parnaseo.uv.es/lemir/Revista/Revista16/Textos/04_Zayas.pdf 
opinião dos outros. ${ }^{10}$ Contudo, o prestígio da mulher leitora entre as classes privilegiadas não alterou as práticas sociais em todos os ambientes socioculturais.

No Brasil, no sertão nordestino do século XIX, a mulher da elite, mesmo com um certo grau de instrução, estava restrita à esfera do espaço privado, assegura Miridan Knox Falci. A pesquisadora registra que muitas filhas de famílias poderosas apenas conheceram as primeiras letras e aprenderam a assinar o nome. Não estudaram nas escolas particulares dirigidas por padres e não foram enviadas a São Luís para o curso médio, nem a Recife ou Salvador, como ocorria com os rapazes de sua categoria social. Enquanto seus irmãos e primos do sexo masculino liam Cícero, em latim, ou Virgílio, recebiam noções de grego e do pensamento de Platão e Aristóteles, aprendiam ciências naturais, filosofia, geografia e francês, elas aprendiam a arte de bordar, crochê e música. "Mesmo muitas mulheres nobres e ricas, como a filha do visconde da Parnaíba, Maria Josefa Clementino de Sousa [1826?-1882], eram analfabetas"11. Pode-se imaginar que o mesmo sucedia em outros espaços rurais e interioranos do Brasil, que se achavam igualmente fundamentados no patriarcalismo, encontrando no cerceamento do acesso à educação uma eficaz forma de controle e sujeição das mulheres.

Superando diferentes dificuldades e barreiras, no século XIX um grande número de mulheres começou a escrever e publicar, tanto na Europa como nas Américas.

10. D'INCAO, op.cit., 1997, p. 228.

11. A afirmação de Falci parte da consulta a documentos oficiais, como testamentos, procurações, cartas de alforria, nos quais se atestava que a Sr. ${ }^{a}$ Maria Josefa pedia ao tabelião que assinasse por ela "por não saber ler nem escrever” (FALCI, Miridan Knox. Mulheres no sertão nordestino. In: DEL PRIORE, Mary, op. cit., 1997, p. 241-277), p. 252. 
No Brasil, por exemplo, Nísia Floresta publicou Direitos das mulheres e injustiça dos homens (1832), uma versão vernácula e livre da obra de Mary Wollstonecraft, Vindications for the rights of woman (1792). A escritora brasileira emprestou da inglesa ideias para enfrentar os preconceitos da sociedade patriarcal e para "reivindicar a igualdade e educação para as mulheres" 12 . No mesmo século, muitas outras brasileiras publicaram romances, poemas, peças teatrais, escreveram artigos em periódicos, fundaram jornais e revistas dedicados às leitoras mulheres, a fim de promover entre elas o hábito da leitura, defender as capacidades das mulheres, enaltecer seu papel social, reivindicar seus direitos, além de ocupar espaço no universo editorial e entre os intelectuais do país ${ }^{13}$.

Graciela Batticuore, em Lectoras del siglo XIX (2017) ${ }^{14}$, afirma que na Argentina formou-se um público leitor feminino, consumidor ativo de cultura, após as campanhas alfabetizadoras dos anos 1860 e 1870 , como resultado da política de fomento às bibliotecas populares do presidente Faustino Sarmiento e da proliferação de folhetins e revistas destinados às mulheres. Neste contexto, o romance atuava a favor da expansão da leitura. Contudo, sobre este gênero incidiam antigos preconceitos, como "el amor se aprende en las novelas" 15 e que os livros de ficção são leitura inflamável, porque ativam a sensibilidade feminina, propensa a desbordar-se em fantasias excessivas. Para os censores da leitura feminina, romances franceses como Madame Bovary, de Flaubert, e As relações perigosas, de Laclos, eram considerados

12. TELLES, op. cit., 1997, p. 405.

13. O capítulo "Escritoras, escritas, escrituras", de Norma Telles, historia um grande número de autoras e editoras, sua produção e notas sobre a recepção de suas obras (1997, p. 401-442).

14. Buenos Aires: Ampersand, 2017.

15. BATTICUORE, 2017, p. 128. 
"lectura nociva"16, porque não ensinavam a mulher a ser uma boa esposa, mas a desejar ser amante; não incentivavam o cuidado do lar e da família, mas o gosto pela diversão e o luxo ${ }^{17}$. A literatura indicada para a mulher é a que ensina história, moral e patriotismo ${ }^{18}$, a que exalta as virtudes ${ }^{19}$. Os censores recomendavam que a leitura das mulheres fosse orientada pelo pai, o marido ou um irmão ${ }^{20}$. Muitos romances argentinos do século XIX traziam a representação da mulher como leitora, ora como modelo positivo, como mãe e esposa dedicada à família e às causas nacionais, ora como negativo, propensa ao amor passional e ao luxo. Batticuore assinala que o prestígio das mulheres leitoras e cultas, no século XIX, na Europa e Argentina, foi registrado em muitas pinturas em que as aristocratas têm um livro nas mãos. Entre os exemplos, Batticuore traz a pintura Doña Pastora Botet de Senillosa [figura 2]. No pequeno livro que tem em mãos está escrito "Beneficencia, aludiendo a su actividad como secretaria administrativa y contable de la institución que fundó Bernardino Rivadavia en la década de 1820"'21. Pode-se pensar que, nesta pintura, se as joias e o rebuscado penteado ilustram a riqueza e dignidade da senhora, uma palavra e um livro concentram relevantes informações sobre a cultura, a capacidade intelectual e o prestigiado papel social da dama retratada.

16. Ibidem, p. 145.

17. Ibidem, p. 150.

18. Ibidem, p. 139.

19. Ibidem, p. 144.

20. Ibidem, p. 144.

21. Ibidem, p. 21. 


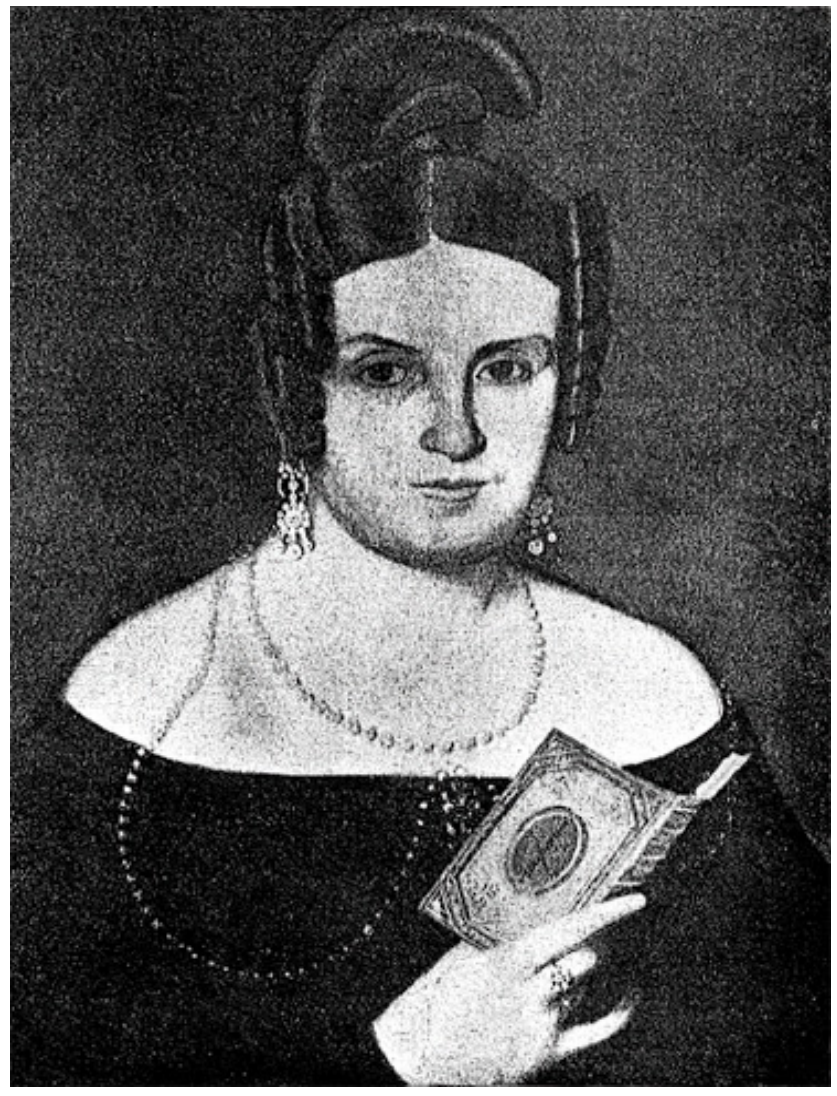

Figura 2 - Doña Pastora Botet de Senillosa, retrato de Carlos Enrique Pellegrini, feito entre 1820 e 1830, na Argentina. Disponível em: http:/ / revistabepe.conabip.gob.ar/node/33 Acesso em: 8 jul 2021.

O mesmo apreço à imagem da mulher leitora provavelmente ocorreu nas letras e artes de outras sociedades ocidentais, nesse período. No contexto brasileiro, pode-se confirmar o gosto e o poder simbólico da imagem da figura feminina dedicando-se à leitura com a foto da Imperatriz Teresa Cristina, de 1865 [figura 3]. 


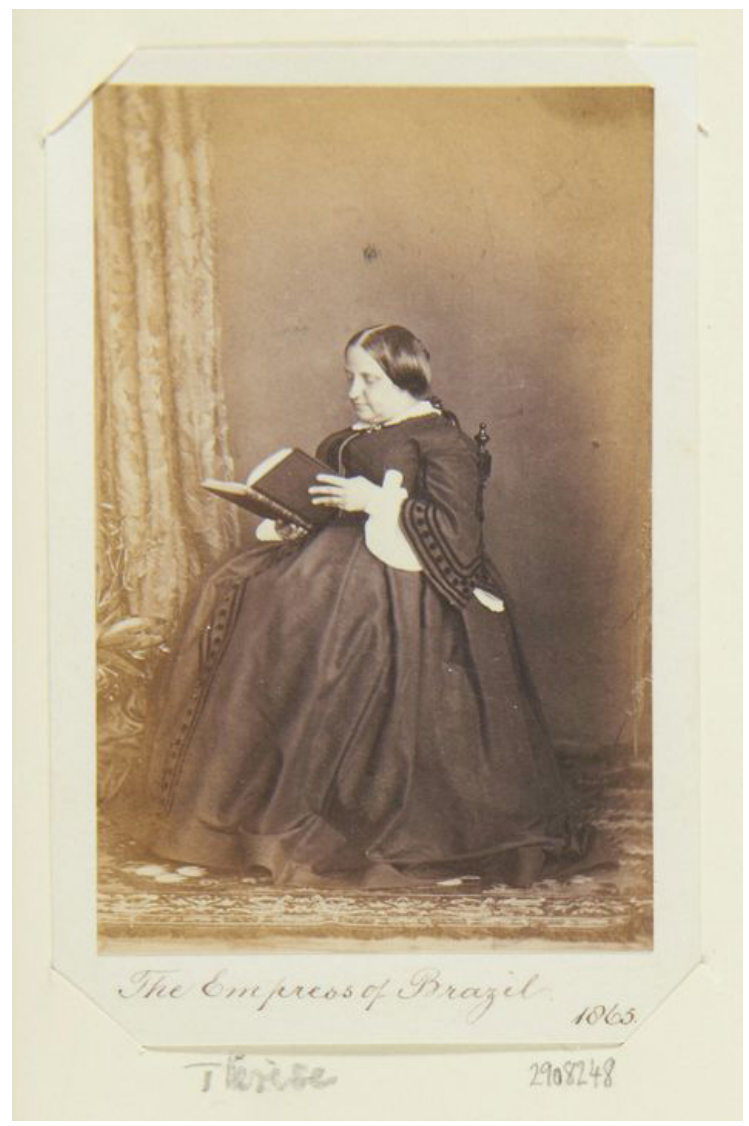

Figura 3 - Dona Teresa Cristina de Bourbon (1822-1889), Imperatriz do Brasil, esposa de Dom Pedro II, em 1865.

Disponível em: https://br.pinterest.com/pin/378654281165071840/ Acesso em: 8 jul 2021.

A imagem da Imperatriz do Brasil deleitando-se com a leitura de um volumoso livro, captada pelas lentes de um daguerreótipo, uma invenção francesa muito recente ${ }^{22}$,

22. No artigo "Os 180 anos do invento do daguerreótipo - pequeno histórico e sua chegada ao Brasil”" (Andrea C. T. Wanderley, 19/8/2019), registra-se que o daguerreótipo foi uma invenção de Joseph Nicèphore Niépce (17651833) e Louis Jacques Mandé Daguerre (1787-1851), anunciada pela Academia de Ciências da França em 19 de agosto de 1839. O instrumento inovador, que revolucionou a arte do retrato, chegou ao Brasil no final do mesmo ano e, 
possivelmente teve grande valor simbólico na representação da modernidade e civilidade do império, bem como das mulheres cultas da elite brasileira ante os olhos do mundo.

Tendo em vista a riqueza das configurações do universo da leitura e da escrita feita por mulheres, em 2019 nós, professoras Andréa Correa Paraiso Müller e Rosangela Schardong, propusemos o simpósio Figurações da mulher leitora e da leitura feminina, realizado no $\mathrm{X}$ Ciclo de Estudos da Linguagem e III Congresso Internacional de Estudos da Linguagem, ocorrido na Universidade Estadual de Ponta Grossa (UEPG), nos dias 29, 30 e 31 de julho. O simpósio teve como objetivos reunir pesquisas e trabalhos que colocassem em evidência os constructos culturais que, durante séculos, mantiveram as mulheres fora do centro da produção de cultura e saber; que desconstruíssem conceitos e representações que difundiram discursos e imagens sobre a pouca habilidade das mulheres para os estudos, para a leitura literária e para a leitura do mundo. Igualmente, o simpósio esteve aberto para pesquisas e trabalhos que enfocassem as representações da mulher como leitora e escritora que problematiza os padrões culturais e políticos, ou atua para a transformação da realidade em que vive. O simpósio propôsse a receber artigos sobre todos os campos das letras e artes, a autoras e autores das sociedades ocidentais, sem limitar o período histórico de sua produção.

Foram muito consistentes e instigantes as pesquisas apresentadas, o que motivou o projeto do livro. As participantes do simpósio foram convidadas a contribuir com seus artigos, a fim de divulgar seus estudos, que enriquecem o

poucos meses depois, em março de 1840, o Imperador Dom Pedro II adquiriu um daguerreótipo, possivelmente o primeiro da América do Sul (Disponível em: https://brasilianafotografica.bn.gov.br/?p=16443. Acesso em: 13 jul 2021). 
universo da história da leitura e da escrita feita por mulheres. Convidamos alguns pesquisadores, brasileiros e estrangeiros, para ampliar o leque das investigações neste campo. $\mathrm{O}$ aceite e a participação de todos honram os organizadores, a todos nosso agradecimento. O Professor René Aldo Vijarra, da Universidad Nacional de Córdoba - Argentina, juntou-se à organização da edição, acentuando a importância dada à congregação de pesquisadores oriundos de diferentes instituições de pesquisa, dedicados a autores, questões, lugares e tempos diversos, unidos em torno dos mesmos problemas de pesquisa: a representação das capacidades femininas, da identidade e do papel social das mulheres, vinculados à prática da leitura e da escrita. Com esta publicação espera-se oferecer ao público de leitoras e leitores um rico e variegado panorama de estudos sobre o tema Ler e escrever, sendo mulher.

Como critério de organização dos textos, escolheuse seguir, em grande medida, a linha cronológica das obras principais analisadas em cada artigo, por entender que, embora possa ser permeada por inúmeras particularidades, a "leitura é sempre determinada pelo lugar ocupado por um leitor na sociedade, num dado momento histórico"23, como afirma Norma Telles. Assim, potencializando as perspectivas de leitura que os textos podem propiciar, almeja-se que os artigos contribuam para a percepção de como os preconceitos e barreiras persistem, alteram-se, são desconstruídos em parte ou no todo - na linha do tempo, na história das mulheres, no mapa das ideias, no prisma das artes e das letras.

Andréa Correa Paraiso Müller, Rosangela Schardong, René Aldo Vijarra Ponta Grossa, 9 de setembro de 2021. 


\section{CAPÍTULO 1}

\section{QUEM TEM MEDO DE EMA BOVARY? \\ IMAGINÁRIO, RECOMENDAÇÕES E DEMANDAS SOBRE A FORMAÇÃO DA MULHER LEITORA}

Rosangela Schardong (UEPG)

¿Qué haces leyendo amores ajenos? Poquito a poco, insensiblemente, vas bebiendo ponzoñas sutiles y venenosos alicientes (...) No me acabo de maravillar cómo no increpan a los padres cuerdos que permiten tal cosa a sus hijas, a los maridos que las dejan hacer, y cómo todos se callan mientras que las mujeres con tales lecturas se van avezando a la maldad.

Juan Luis Vives (Formación de la mujer cristiana, 1523/1947, p 1002)

Poderia a leitura contaminar a mente das mulheres com sutis e sugestivos venenos? A interrogação de Juan Luis Vives (1523/1947, p. 1002), que serve de epígrafe a este artigo, seguida da admoestação dirigida aos pais e maridos, ilustra o imaginário e os discursos em torno à leitura feminina na Espanha da primeira metade do século XVI. Contudo, estiveram presentes por um longo período na cultura ocidental e hispânica. Este artigo debruça-se sobre a extensa tradição 
do controle masculino da leitura feita pelas mulheres, apoiada em preconceitos acerca da fragilidade do intelecto e da psique femininos, a fim de evidenciar tais constructos culturais que perduraram na história do acesso das mulheres à leitura, à educação, ao exercício da cidadania e dos direitos políticos. A partir de tratados de educação feminina publicados na Espanha, nos séculos XVI e XVII, de larga vigência na Península Ibérica e suas colônias americanas, o artigo lança luzes sobre a perpetuação de semelhantes discursos sobre o papel social das mulheres e os efeitos nocivos da leitura de romances no final século XIX e início do XX na Argentina, quando o modelo de Madame Bovary era o principal alvo dos censores. $\mathrm{O}$ artigo aponta como esta longa tradição começa a ser desconstruída pelas demandas do movimento feminista, enunciadas em um congresso internacional de mulheres em Buenos Aires, em 1910.

Com a invenção e o desenvolvimento da imprensa, no século $\mathrm{XV}$, pouco a pouco vão surgindo novos gêneros literários e novas categorias de leitores. A leitura deixa de ser uma capacitação profissional para converter-se em uma atividade recreativa, aponta B.W. Ife (1992, p. 11-12) ${ }^{1}$. Na Espanha, no século seguinte, essa nova dimensão da leitura preocupava seriamente pregadores da Igreja Católica, intelectuais e políticos. Houve várias tentativas de proibir a publicação de livros de ficção e sua exportação para as colônias (IFE, 1992, p. 20). Os censores temiam o efeito nefasto da ficção sobre o juízo e a psique dos leitores. Um deles, o jesuíta Gaspar Astete, acreditava que os livros incitavam mais a pecar do que as tentações mundanas (apud IFE, 1992, p. 26). Ife explica que o temor provinha

1. Agradeço imensamente à Prof. ${ }^{a}$ Dr. ${ }^{a}$ Maria Augusta da Costa Vieira, minha orientadora no mestrado e no doutorado, por toda a bibliografia que me indiciou e ajudou a ter acesso, entre ela esta obra de B. W. Ife. 
do conceito platônico de que o dano não está em que se leia sobre o mal, mas que "el mal se experimenta realmente durante la lectura" (1992, p. 27), uma vez que a ficção favorece o desfrute de experiências alheias por meio da identificação entre o público e as personagens, assim como pela catarse (ibidem). Juan Luis Vives interroga: "qué locura es verse poseído y arrastrado por estos libros?”, o que leva Ife a sintetizar: os censores da ficção temiam "la invasión de la mente racional por la irrealidad de la ficción” (1992, p. 37).

Note-se que justamente é o que ocorre com Dom Quixote, o fidalgo manchego que enlouqueceu de tanto ler e passou a acreditar que poderia ser um bravo cavaleiro andante. Mercedes Alcalá Galán, em Escritura desatada (2009), afirma que Cervantes fez de Dom Quixote a personificação de uma réplica irônica aos censores da leitura de ficção, ao mesmo tempo em que compôs uma paródia às novelas de cavalaria e um elogio às narrativas de entretenimento.

Muitos já indicaram as semelhanças entre Dom Quixote e Ema Bovary. Ortega y Gasset, em Meditaciones del Quijote (1914), formulou o célebre epíteto: Madame Bovary é um Dom Quixote de saias ${ }^{2}$. Pode-se observar que o principal traço que assemelha os protagonistas é o desejo de viver as aventuras, os lances de perigo, os amores e as glórias que leram em incontáveis romances. Além disso, ambos procuram externar, em sua aparência, sua autoimagem. O fidalgo enlouquecido vestiu armadura para figurar o seu espírito guerreiro, sua prontidão para o combate e a vida heróica. A dama francesa comprou faixas, chapéus, luvas, ricos vestidos

2. José Ortega y Gasset, em Meditaciones del Quijote (1914), formulou o célebre epíteto: "Madame Bovary es un don Quijote con faldas". Também Mário Vargas Llosa, em La orgía perpetua: Flaubert y Madame Bovary (1975), compara aspectos do cavaleiro espanhol com a dama francesa, entre muitos outros autores e pesquisadores. 
azuis, deu presentes caros, cercou-se de fina mobília para que sua aparência exterior refletisse o que levava na alma: o desejo de ser a protagonista de um romance romântico, de beleza cativante e elegância ímpar, que arrebata amores, segredos, pactos, infidelidades e toda a sorte de paixões que traduzem, para ela, a felicidade.

Talvez se possa dizer que, assim como a curiosa loucura de Dom Quixote parodia a pretensão dos doutores da igreja de conhecer e controlar a mente e a vida dos seculares, e ironiza os ideais masculinos de virtude e prudência ${ }^{3}$ da época, o romance francês também traz substancioso protesto. A tragédia pessoal de Ema Bovary denuncia como é falso e ilusório o modelo de felicidade feminina após o casamento, no papel de dóceis esposas e dedicadas donas de casa ${ }^{4}$. A vida cheia de atribulados lances amorosos das personagens dos romances que Ema lia certamente era muito mais excitante que sua rotina de mulher de um médico do interior. A crítica aos constructos culturais de seu tempo é, portanto, outro traço que assemelha a trama que envolve o fidalgo manchego e a protagonizada pela dama francesa.

No século XVII, na Espanha que viu a publicação do Quixote, as mulheres das classes privilegiadas recebiam

3. A ascensão do Humanismo, nas cortes europeias, fez surgir uma série de manuais de cortesia e civilidade a fim de instruir os homens da nobreza e das classes privilegiadas no cultivo dos modos e das virtudes que convinham ao perfeito homem da corte. O principal modelo destes tratados é $O$ Cortesão (1528), do italiano Baldassare Castiglione. Em toda Europa logo surgiram traduções e composições similares vernáculas. Na Espanha $O$ Cortesão foi traduzido em 1534, por Juan de Boscán. No século XVII os tratados El héroe, El discreto e Oráculo manual y arte de prudencia, de Baltasar Gracián, foram muito prestigiados.

4. A própria Ema diagnostica que passou a sofrer "ataques de nervos" (FLAUBERT, 1944, p. 103) após o casamento. É possível inferir que as crises de ansiedade se devam à percepção de que a vida de casada não correspondia ao seu sonho de felicidade, idealizado a partir da leitura de romances românticos. 
escassa educação. Como em Madame Bovary, só nos conventos havia a possibilidade de ampliar os estudos. ${ }^{5}$ A maioria era alfabetizada em casa e sua instrução era complementada pela leitura de manuais de educação feminina, escritos majoritariamente por pregadores católicos. Em Formación de la mujer cristiana, publicado em 1523, o humanista Juan Luis Vives afirma que "la mayor parte de los vicios de las mujeres" (...) hijos son de la ignorancia, porque jamás leyeron ni oyeron aquellos egregios loores y avisos de los Santos Padres acerca de la castidad, del apartamiento, del silencio, de los adornos y arrequives de la mujer" 7(1523/1947, p. 997). Logo apresenta uma lista de mulheres da Antiguidade greco-romana ${ }^{8}$, de

5. Mariló Vigil, em La vida de las mujeres en los siglos XVI y XVII, afirma que as mulheres da nobreza recebiam escassa educação, em casa, ministrada por seus familiares ou por um tutor. Vigil registra a recomendação do pregador Alonso de Andrade para que as meninas sejam educadas em colégios internos de freiras, logo depois de serem desmamadas (1994, p. 57). A prática de enviar as meninas, ainda muito criança aos conventos, para que fosse educadas na fé e nas letras, foi de fato uma prática social, muitas vezes censurada, como aponta o historiador José Sánchez Lora, em Mujeres, conventos y formas de la religiosidad barroca, em especial no capítulo III "Del claustro familiar al claustro monástico" (1988, p. 139-163).

6. Longe de pensar ou propor que os nativos de língua portuguesa naturalmente entendem o espanhol, pela aparente semelhança entre línguas, neste artigo, cujas fontes de pesquisa são majoritariamente nesta língua estrangeira, opta-se por traduzir, em nota de rodapé, apenas os textos do século XVII, em que é empregado vocabulário específico, próprio da língua culta de seu tempo, e algumas citações de obras do século XIX. As traduções serão todas minhas, assinaladas com a abreviação T. A. (tradução da autora do artigo).

7. Vives acredita que a maior parte dos vícios das mulheres são filhos da ignorância, porque jamais leram ou ouviram aqueles egrégios louvores e avisos dos santos padres sobre a castidade, o retiro, o silêncio, os adornos e virtudes que embelezam a mulher. (T. A.)

8. Por exemplo, a poetisa Safo de Lesbos, Semprônia e Cornélia, mãe dos Gracos (VIVES, 1947, p. 997). 
santas $^{9}$, de célebres rainhas ${ }^{10}$ e damas da Europa e Espanha que são exemplo de "destreza de ingenio para todo género de letras y, a la vez, de una singular honestidad y buen sentido" 11 (1947, p. 1000).

Vives assegura que "el estudio de las letras (...) ocupa el alma toda del hombre, y luego eleva el entendimiento a la contemplación de la soberana hermosura tan eficazmente, que aparta del espíritu todo pensamiento de torpezas" (1947, p. 1000). Entretanto, parece que ele atribui esse benefício somente à alma dos homens, pois em seguida, recomenda que as meninas aprendam a ler em obras que ensinam compostura, para que o pudor as incline a preferir o silêncio e a estarem subordinadas a seus maridos (1947, p. 1001).

Vives faz grave censura aos livros de ficção, especialmente às novelas de cavalaria, que tratam de armas e de amores. Pergunta à donzela: que fazes lendo amores alheios? Pouco a pouco, sem perceber, vais bebendo peçonhas sutis e venenos sedutores. Vives espanta-se que não sejam severamente advertidos os pais que permitem que suas filhas tenham acesso a tais leituras, tampouco os maridos que as consentem, e de como todos se calam enquanto as mulheres,

9. Tais como Tecla, discípula de São Paulo, [Santa] Catarina de Alexandria e Hildegarda [Bingen] (VIVES, 1947, p. 999).

10. Entre outras cita a "la reina doña Juana, mujer del Rey don Felipe y madre de ese nuestro emperador y rey don Carlos [Carlos V]” (VIVES, 1947, p. 999).

11. Vives descreve, com tais palavras, Doña Angela Mercader Zapata, conterrânea sua, de Valência. Julgo que os mesmos atributos são extensivos às demais mulheres que compõem a lista de exemplos. Vives reconhece nela destreza de engenho, isto é, a capacidade e agilidade cognitiva para compreender todo gênero de leituras e, ao mesmo tempo, uma singular honestidade e bom senso. (T. A.) 
com esses livros ${ }^{12}$, pouco a pouco vão-se afeiçoando à maldade $^{13}$ (1947, p. 1002).

Em seu julgamento Vives coloca em evidência uma prática cultural de seu tempo, de que a leitura das mulheres estivesse sob a supervisão de uma autoridade masculina: o pai ou o marido. Seu texto recomenda o zelo dos tutores, uma vez que a mulher, diz ele, é um ser fraco, de pouco juízo, e muito exposto ao engano, como mostrou Eva, que se deixou enganar pelo demônio (1947, p. 1001).

Vives adverte que algumas mulheres "están mal dotadas para aprender las letras" (1947, p. 1001). Esse preconceito sobre a capacidade intelectual das mulheres foi repetido por vários tratadistas e, em função desta falsa premissa, para não sobrecarregar o intelecto feminino era recomendado que as mulheres fizessem apenas leituras que estimulassem a virtude, a obediência às leis de Deus, orientassem o governo da casa e a educação dos filhos (1947, p. 1002-1005).

$\mathrm{Na}$ segunda metade do século XVI, Fray Luis de León, com o célebre tratado La perfecta casada (1583), ratifica os preceitos católicos para a educação das mulheres. Centra suas lições no principio de que "el fin para que Dios la crió es para que sea ayudadora del marido"14(1968, p. 41). Consequentemente, a natureza teria limitado sua capacidade intelectual:

12. Entre os "libros pestíferos", Vives condena obras de diferentes gêneros, nos quais a aventura e a matéria amorosa são predominantes: Amadís, Esplandián, Florisandro, Tirante [romances de cavalaria], Tristán [romance do ciclo artúrico], Celestina [tragicomédia], Cárcel de amor [romance sentimental], Lanzarote del lago [romance de cavalaria], Paris y Viana, Píramo y Tisbe [romances bizantinos], entre outros títulos, terminando a lista com o Decamerón, de Boccaccio [contos emoldurados] (VIVES, 1947, p. 1003).

13. Tradução da autora para a citação que serve de epígrafe para o artigo.

14. O fim para que Deus a criou é para que ajude o seu marido. (T. A.) 
Así como a la mujer buena y honesta la naturaleza no la hizo para el estudio de las ciencias ni para los negocios de dificultades, sino para un oficio simple y doméstico, así les limitó el entender, y por consiguiente, les tasó las palabras y las razones ${ }^{15}$ (LEÓN, 1968, p. 124).

Entende-se que León atrela a capacidade intelectual das mulheres ao gênero, cuja existência justifica-se nos papéis de esposa e mãe, os quais prescindem de educação para as letras e ciências.

Em 1634, o poeta e prosista espanhol Francisco de Quevedo traduz para o castelhano o tratado de educação feminina Introducción a la vida devota (1608), de Francisco de Sales, bispo de Genebra. Sales dirige as recomendações a Filotea, figuração de sua leitora e interlocutora. Nota-se que a vida devota se configura como um caminho para a honestidade, isto é, a virtude da donzela católica aristocrata que frequenta as cortes europeias. Entre as muitas lições, o autor censura os amores vãos e as "amistades locas", aquelas que "se practican entre gente de diverso sexo y sin pretensión de matrimonio" (1992, p. 1830). Para libertar-se dessas afeições, Sales recomenda: "lee los libros devotos" (1992, p. 1837), e "recrea tu alma con buenas meditaciones y santos pensamientos, o con alguna buena lectura” (1992, p. 1843) as quais, entende-se, seriam leituras de devoção - seguindo o exemplo do bispo Nazianzeno ${ }^{16}$ e de São Ambrósio, que foram doutores da Igreja.

15. Assim como a natureza não fez a mulher boa e honesta para o estudo das ciências, nem para os negócios de dificuldades, mas para um ofício simples e doméstico, do mesmo modo limitou-lhes o entendimento e, consequentemente, reduziu-lhes o uso das palavras e da razão. (T. A.)

16. Em outros trechos Sales se refere a San Gregorio Nazianzeno (1992, p. 1831). Segundo o site da Arquidiocese de São Paulo, Santo Gregório Nazianzeno (329, Capadócia - 390) foi educado nas melhores escolas e academias da 
Vale destacar, neste tratado, que a leitura exclusivamente a devota- é aludida como remédio para a alma e como exercício de fortalecimento espiritual, não como instrumento de educação ou fonte de entretenimento. Por isso, entre as formas de recreação (divididas entre lícitas e louváveis ${ }^{17}$; ou lícitas, mas perigosas ${ }^{18}$ ), o bispo não menciona a leitura (SALES, 1992, p. 1853-1856).

A respeito dos exemplos de leitores, é relevante considerar que Sales, ao longo do tratado, cita grandes figuras femininas da Igreja, as quais foram mulheres letradas e muito instruídas, como Santa Catarina de Siena ${ }^{19}$ (1992, p. 1822),

Antiguidade. Tornou-se um famosíssimo orador e teólogo sendo muito perseguido pelos arianos. Por isto, preferiu desistir da vida episcopal e se recolher num mosteiro onde se dedicava inteiramente às orações, à meditação, ao estudo do Evangelho. Em virtude de sua grande erudição teológica, foi escolhido bispo de Constantinopla. Foi patriarca desta metrópole e presidiu o primeiro Concílio Ecumênico da Igreja ali, em 381. Mais tarde abdicou do cargo para voltar à solidão de monge, ao trabalho literário e ao exercício de meditação. Seu legado de sermões, cartas e poemas é considerado um tesouro do testemunho ortodoxo (http://www.arquisp.org.br/liturgia/santo-do-dia/ santo-gregorio-nazianzeno. Acesso: 2/6/21).

17. Sales classifica como "pasatiempos y recreaciones (...) lícitos y loables": "tomar el aire, pasearse, entretenerse con discursos alegres y amigables, tocar el laúd y otros instrumentos, cantar música, ir a caza", ainda o jogo de xadrez e os jogos com bola (1992, p. 1853-1854).

18. Para Sales os passatempos lícitos, mas perigosos, seriam as danças, bailes e festejos noturnos, porque ocorrem "en medio de las tinieblas y obscuridad, y así es fácil el deslizarse a muchos accidentes y tenebrosos vicios". Para o autor, a escuridão da noite, a música e a dança despertam na alma "mil suertes de malas aficiones" e incitam os amores perigosos (1992, p. 1854-1855). Nota-se que as recomendações de Sales incidem sobre a preocupação maior da educação das moças da aristocracia europeia: a virgindade.

19. Em Formación de la mujer cristiana (1523), na lista de mulheres célebres que foram muito cultas e virtuosas está "Catalina de Siena, virgen doctísima, que nos dejó insignes monumentos de su ingenio, en los cuales resplandece como perla oriental de limpieza de su alma santísima” (VIVES, 1947, p. 999). A descrição elogiosa de Vives confirma a hipótese de que Sales poderia, sim, ter escolhidos entre as vidas de santas alguns modelos femininos como exemplo de grande leitora e hábil escritora. 
Santa Isabel, filha do Rei da Hungria (1992, p. 1827) e Santa Mônica (1992, p. 1863). No entanto, Sales não as aponta como exemplos de leitoras. Pode-se pensar que a decisão do autor nega a Filotea, sua leitora, o acesso à informação de que houve mulheres que cultivaram aos estudos. Como preceptor, Sales recomenda os convencionados papéis de donzela e esposa honesta.

Sobre a leitura devota, Juan Luis Vives, em Formación de la mujer cristiana (1523/1947), recomenda a leitura dos Evangélios, dos Atos dos Apóstolos e suas epístolas, das obras de São Jerônimo, Santo Agostinho e outros doutores da Igreja. Inclui as obras morais de Platão e Sêneca. Ao terminar a lista, Vives determina: "sobre algunos autores tendrán que ser consultados varones doctos y sensatos"20 (1947, p. 1005), reforçando a necessidade de que a leitura feminina seja supervisionada e guiada por um homem ilustrado.

Tendo-se em conta os tratados de educação feminina mencionados, compreende-se que a leitura destes textos deveria formar a mulher católica da nobreza e das classes privilegiadas no caminho das virtudes consideradas apropriadas para o seu gênero: castidade, humildade, obediência, devoção a Deus, ao marido, ao lar e aos filhos. ${ }^{21}$

20. Sobre [a leitura de] alguns autores haverá que consultar varões de grande saber e prudência. (T. A.)

21. É importante considerar que, na Espanha dos séculos XVI e XVII, também as mulheres das classes não nobres, urbanas ou rurais, estavam sujeitas à vigilância dos familiares e das autoridades religiosas. Os motivos são vários. Um deles diz respeito ao modelo do amor cortês, difundido pelas novelas de cavalaria, o teatro e outras formas de arte. Mariló Vigil assegura que "la cultura del amor cortés fue patrimonio de todas las clases sociales y de personas de muy diversos niveles educativos, incluidos analfabetos y analfabetas" (1994, p. 62). Esse modelo enaltecia a amabilidade da mulher casta e virtuosa. Outro motivo, assinalado por Salazar Rincón, é que "la nobleza, situada en la cúspide de la pirámide jerárquica, se ha convertido en el punto de confluencia de todas las aspiraciones colectivas" ocasionando "la adopción mimética de 
Chama atenção que o imaginário sobre os perigos da leitura de romances, repletos de aventuras amorosas, sobre o intelecto e a psique femininos, expresso pelo humanista Juan Luis Vives, na primeira metade do século XVI, repetese nas campanhas pela educação das mulheres na Argentina do século XIX, assim como a recomendação de que uma autoridade familiar masculina seja a tutora da leitura feita pelas mulheres.

Graciela Batticuore, em Lectoras del siglo XIX (2017), afirma que na Argentina formou-se um público leitor feminino, consumidor ativo de cultura, após as campanhas alfabetizadoras dos anos 1860 y 1870, como resultado da política de fomento às bibliotecas populares do presidente Faustino Sarmiento e da proliferação de folhetins e revistas destinados às mulheres. Neste contexto, o romance atuava a favor da expansão da leitura. Contudo, sobre este gênero incidiam antigos preconceitos, como "el amor se aprende en las novelas" (2017, p. 128) e que os livros de ficção são leitura inflamável, porque ativam a sensibilidade feminina, propensa a desbordar-se em fantasias excessivas. Para os censores da leitura feminina, romances franceses como Madame Bovary, de Flaubert, e As relações perigosas, de Laclos, eram considerados "lectura nociva" (2017, p. 145), porque não ensinavam a mulher a ser uma boa esposa, mas a desejar ser amante; não incentivavam o cuidado do lar e da família, mas o gosto pela diversão e o luxo (2017, p. 150). A literatura recomendada para as mulheres era a que ensinava

las formas de vida noble por parte de los grupos inferiores" (1985, p. 298). Possivelmente os sermões e a leitura dos romances de cavalaria levavam às mulheres das classes pobres e camponesas o ideal da castidade feminina como símbolo da virtude e honra das donzelas e esposas. No Quixote, ilustram ficcionalmente estes valores a asturiana Maritornes, que "presumía muy de hidalga" (CERVANTES, 1990, p. 158), a esposa e a filha de Juan Palomeque (I, 16-17, 32). 
história, moral e patriotismo (2017, p. 139) e a que exaltava as virtudes (2017, p. 144), para tanto, a leitura das mulheres deveria ser orientada pelo pai, o marido ou um irmão (2017, p. 144). Pode-se considerar que a recomendação de que haja um tutor masculino para a leitura indica que os preceitos do século XVI sobre a fragilidade da natureza e do intelecto das mulheres, ditados pelos tratadistas espanhóis, ainda estavam vigentes na cultura da sociedade argentina do século XIX e, possivelmente, em toda a América Latina.

Buscando as causas que geravam os temores sobre a leitura feita pelas mulheres no século XIX, Graciela Batticuore aponta o romancista francês Gustave Flaubert:

El que forjó el tipo de la lectora moderna: Emma Bovary, una mujer socialmente peligrosa que cae en el vicio del consumo y la infidelidad leyendo historias que atentan contra la moral burguesa y las convenciones de la época. Desde entonces, Bovary fue el espejo en el que se miraron y se proyectaron tantas otras heroínas de novelas americanas, muchas de ellas argentinas (BATTICUORE, 2017, p. 149).

Flaubert, com certeza, jamais premeditou ou soube da repercussão que seu romance Madame Bovary causou no pensamento e nas práticas sociais latino-americanas.

Entre as obras listadas por Batticuore chama atenção o romance El lijo (1889), de Lola Larrosa, cujo título mais notadamente parece espelhar, nas letras argentinas, a projeção do modelo de Madame Bovary (1857), cuja ruína material e moral foram, em boa medida, impulsionadas pelo gosto por roupas e objetos luxuosos. De acordo com Vanessa Guerra (2013), a protagonista de El lujo, Rosalía, é uma moça que gosta de estar bem vestida e arrumada desde o amanhecer, mas mora num sítio, tem que alimentar os porcos e cuidar 
da horta. A mãe descobre a causa da esquisitice: os romances estrangeiros que a filha lê. Para remediar o problema queimaos e trata seu casamento com um lavrador. No entanto, Rosalía consegue que umas amigas ricas a levem para Buenos Aires e assim empreende uma viagem ao encontro do luxo tão sonhado ${ }^{22}$.

Natalia Crespo, no artigo "Representaciones del hogar rural" (2016), analisa dois romances argentinos do século XIX escritos por mulheres, Margarita (1875), de Josefina Pelliza, e El lijo (1889), de Lola Larrosa, obras que foram marginalizadas pela historiografia literária nacional. Crespo aponta que as autoras ocuparam a direção da revista La alborada literaria del Plata, junto com a sua fundadora, Juana Manuela Gorriti, autora destacada nas letras argentinas. Crespo acrescenta que Pelliza e Larrosa colaboraram com muitos artigos para a revista. Como romancistas, cultivaram o gênero melodramático, sob uma perspectiva bastante conservadora a respeito da sociedade e da mulher. A estudiosa avalia que ambas as autoras "concibieron la labor literaria como una praxis orientada a educar moralmente a las jóvenes lectoras" (2016, p. 144) dentro dos ideais femininos de domesticidade, matrimônio e maternidade que predominavam na sociedade argentina, patriota e conservadora, do seu tempo.

A fim de indicar como os romances Margarita ${ }^{23}$ e El lujo cristalizam os valores de seu tempo, Crespo resgata um

22. Vanessa Guerra é autora do prólogo de El lijo, de Lola Larrosa. Disponível em: https://coleccionlasantiguas.blogspot.com/2013/01/el-lujo-de-lolalarrosa.html Acesso em 28/7/2019.

23. Margarita é um romance classificado por Crespo como melodramático. A trama inicia com o assédio de Margarida, aos 17 anos, pelo homem que ela pensava ser seu pai, o italiano Saavedra. O desenrolar do enredo revela que a jovem foi sequestrada de sua família, cujos pais tinham uma vida pacata em sua casa no campo. A felicidade do lar foi perturbada quando o casal recebeu um estrangeiro, Saavedra, que assediou Andrea, a esposa e, como ela recusasse 
artigo do jornal argentino La Nación, de 27 de setembro de 1885, no qual Federico Tobal celebra a publicação de Conferencias, um livro de ensaios relativos à mulher, de Josefina Pelliza. O comentarista julga que os ensaios desenvolvem brilhantemente o seguinte preceito de Alberdi24: a respeito da mulher, sua instrução não deve ser brilhante. Não deve consistir em talentos de ornato e luxo exterior, como a música, a dança, a pintura, como foi até aqui. Necessitamos senhoras e não artistas. A mulher deve brilhar com o brilho da honra, da dignidade, da modéstia de sua vida (apud CRESPO, 2016, p. 144). Tobal, então, inclui sua reflexão sobre a formação das mulheres, a partir do papel que devem desempenhar:

Sus destinos son serios; no ha venido al mundo para ornar el salón, sino para hermosear la soledad fecunda del hogar. Darle apego a su casa es salvarlo; y para que la casa la atraiga, se debe hacer de ella un edén. Se le debe reemplazar el lujo de las caravanas, de los trajes espléndidos y de las cosas de ostentación por el lujo del dormitorio, de la cama, de la mesa, de la cocina, de los jardines interiores, y de todo lo que hace ser feliz sin llamar la atención

ceder a seus apelos, sequestrou sua filha, ainda bebê. No final, após muitos sofrimentos e peripécias, Margarita volta para o convívio dos pais, reencontra seu namorado e resgatam o filho que tiveram. A "virtude triunfante" é o tema central do romance, destaca Crespo (2016, p. 146). Convém ponderar que o romance, ainda que exalte o papel convencional da mulher, como esposa e mãe, pode ser entendido como obra que enaltece a mulher, ao centrar-se no protagonismo feminino e depositar na personagem principal as maiores virtudes. Outro aspecto a ser salientado é o elemento perturbador, na trama: o estrangeiro, que desvirtua o lar rural.

24. Possivelmente trata-se de Juan Bautista Alberdi (Argentina, 1810-1885). De acordo com o artigo "Estado e Modernidade em Alberdi e Sarmiento" (2001), de Affonso Celso Thomaz Pereira, Alberdi foi um grande escritor, político e intelectual argentino. Fez parte da Geração de 37 e da Associação de Maio. Entre suas muitas atividades dedicou-se ao jornalismo e fundou o jornal La Moda, em 1837, em Buenos Aires. 
del público (TOBAL, 27/9/1885, apud CRESPO, 2016, p. 144).

É notável que as declarações de Alberdi e Tobal, que recomendam restringir a educação das mulheres em função do papel social que elas devem ocupar no espaço doméstico, parecem atualizar, na Argentina do século XIX, em discursos laicos, as mesmas recomendações feitas pelos pregadores europeus católicos, para a educação das mulheres da aristocracia nos séculos XVI e XVII.

Percebe-se que o discurso destes homens de letras latino-americanos pretende inculcar nas mulheres a rejeição ao "luxo exterior", à música e à dança própria dos encontros sociais, para que amem a elogiada "solidão fecunda do lar", onde devem brilhar por sua honradez e sublimada modéstia edificante. Para tanto, não énecessária uma instrução esmerada, segundo depreende-se das palavras de Alberdi e Tobal, que atualizam e perpetuam o ancestral constructo cultural de que a educação moral das mulheres é mais importante do que sua educação para as letras, artes e ciências.

No romance El lujo, Crespo considera que Roque, o pastor do povoado de Rosalía, sintetiza em suas palavras o pensamento do seu tempo sobre os efeitos que o fascínio pelo luxo causava nas mulheres:

En todas partes del orbe (...) la pasión por el lujo se posesiona del corazón de las mujeres, obligándolas a olvidarse de la familia y de los sentimientos más santos para entregarse al afán desmedido de brillar y de ser citadas como modelo de elegancia y de belleza y de buen gusto (LARROSA, 1889, apud CRESPO, 2016, p. 152).

Crespo analisa que, neste romance, o luxo figura como o oposto da austeridade e do sacrifício, como expressão do 
ócio, da imaginação frondosa, da vida despreocupada, da ausência do trabalho, do desejo de consumo, da excessiva valorização da aparência física e, ainda, da propensão para enganar e ser enganado. Enquanto o seu antônimo são a simplicidade e a felicidade de cuidar do pouco que se tem em um lar rural.

O desejo de viver no luxo é "la célula destructora de todo bienestar (es decir, del bien estar doméstico)" diz Crespo (2016, p. 146). Após a ruína financeira das amigas que sustentaram a vida luxuosa de Rosalía em Buenos Aires, ela passa a ser desprezada pela alta sociedade, cai na miséria e se arrepende de ter menosprezado a vida que tinha em seu povoado. Então regressa e aprende a ser feliz junto aos seus. O romance El lujo ensina, com um contra exemplo, o que as jovens não devem fazer, ao mesmo tempo em que expressa um elogio à literatura nacional e moralizante (2016, p. 145149), afirma Crespo.

Entende-se que a trama de El lijo indica que sua protagonista espelha a trajetória de Ema Bovary, tendo sua vida profundamente marcada pelas leituras que fez, como destaca a voz narrativa, em tom de alerta: "a veces, bajo la forma seductora del libro, se introduce en el seno del hogar el enemigo malo que ha de trastornar la existecia inocente y sosegada de la inexperta niña" (LARROSA apud CRESPO, 2016, p. 150). Como a dama francesa, por causa das leituras de romances nocivos, que a levam a desejar viver uma vida muito diferente da sua, Rosalía se afasta do modelo do "anjo do lar"25 e, por isso, padece grandes sofrimentos.

Chama atenção que o fascínio de Ema Bovary e suas descendentes latino-americanas pelo luxo tenha gerado um potente imaginário sobre a atração das mulheres sobre a

25. Batticuore diz “ángel del hogar” (2017, p. 150). 
riqueza, diretamente relacionada aos perigos da dissolução dos costumes e do modelo da virtuosa rainha do lar. O alcance deste imaginário fica evidente nas preocupações registradas nas atas de dois congressos de mulheres realizados na Argentina, em 1910, quando o país celebrava o centenário da Revolução de Maio, que deu origem aos movimentos para a independência nacional. ${ }^{26}$ Tanto as participantes do congresso organizado pelas feministas, quanto as signatários do evento das Senhoras Patriotas, oligarcas e conservadoras, recomendam que as mulheres sejam educadas para discernir o perigo do luxo, em clara alusão a Madame Bovary e aos romances vernáculos que deram continuidade a sua linhagem.

É necessário ponderar que as atas do Primer Congreso Femenino Internacional de la República Argentina, organizado pela associação Universitárias Argentinas, de inclinação socialista e feminista, registram uma única advertência ao gosto pelo luxo. Na seção Educação, Letras, Artes e Indústrias, Carmen Champy Alvear apresentou o trabalho "Importancia de la cultura estética en la educación de la mujer” (2008, p. 143-147), no qual propõe que, desde a escola primária, a sensibilidade estética das mulheres seja formada através do estudo das artes. Argumenta que célebres pinturas europeias e nacionais poderiam ensinar história, costumes, noções de harmonia das cores e formas, enfim, poderia despertar o gosto pelo belo. A autora enfatiza que este aprendizado "debe tender a un fin práctico para que más tarde tenga su aplicación en los trabajos industriales, en el taller, en la casa, en la escuela, etc", de modo que auxilie a mulher "en la lucha por la vida" (2008, p. 147). As atas registram que o Congresso deliberou sobre

26. Para compreender melhor o entrave dos dois congressos de mulheres em maio de 1910, em Buenos Aires, é muito esclarecedor o prólogo de Jaqueline Vasallo e Leandro Calle em Alfonsina Storni: literatura y feminismo en la Argentina de los años 20 (Villa María, AR: Eduvim, 2014, p. 13-26). 
o trabalho, aprovou suas propostas, porém, incluiu a seguinte proposição: "el Congreso Femenino Internacional hace votos porque [para que] se eduque a la mujer en el sentido de que comprenda el peligro que entraña el lujo” (2008, p. 147).

A Historia de las trabajadoras en Argentina (2007), de Mirta Zaida Lobato, registra que as mulheres empregavamse principalmente em fábricas e oficinas de produção de tecidos, roupas, chapéus, luvas, bordados e flores artificiais. Sendo assim, a proposta de ensino de artes parece sumamente pertinente e útil. Ante esta compreensão, muitas hipóteses poderiam ser formuladas acerca da advertência do Congresso Feminino sobre os perigos do luxo. Considerando as conotações ${ }^{27}$ dadas pelo romance de Lola Larrosa, seria possível sintetizar que a cultura da época entendia a afeição à estética europeia e ao luxo, isto é, a excessiva preocupação com a aparência, o gosto pelas joias, acessórios e roupas refinadas, como uma tendenciosa propensão para o desvio dos padrões de conduta feminina estimados, tanto pelas classes privilegiadas como pelas classes trabalhadoras.

Educar as mulheres para compreender os perigos do luxo talvez seja uma proposta motivada pelo prestigiado imaginário de que as mulheres, como esposas, mães e, até mesmo como irmãs, tinham forte influência sobre o caráter

27. Por intermédio das palavras de Rosalía, a protagonista do romance El Lujo, pode-se inferir o significado de luxo na época, isto é, a partir da figuração do imaginário de uma leitora de romances românticos, da classe rural: "yo quisiera deslumbrarme con las riquezas y oropeles que el mundo ofrece (...) cubrirme de sedas y de encajes y ataviarme con piedras preciosas (...) vivir en un palacio con aposentos muy grandes y jardines frondosos, con fuentes y saltadores y estatuas, y mucha servidumbre (LARROSA apud CRESPO, 2016, p. 151-152). Em português, seria: eu queria desfrutar das riquezas e preciosidades que o mundo oferece, cobrir-me de sedas e rendas, embelezar-me com pedras preciosas, morar num palácio com salas e quartos enormes, com jardins frondosos, com fontes, chafarizes e estátuas, e com muitos criados. (T.A.) 
dos homens, dos filhos e, consequentemente, da nação. ${ }^{28}$ Deste modo, importava muito para a sociedade argentina do início do século XX a retidão da conduta feminina.

Não há como avaliar se essas hipóteses são plenamente acertadas, contudo, não se pode negar que o parecer do congresso à proposta de Carmen Champy Alvear manifesta uma voz coletiva e, por isso, representativa e digna de nota nas atas do evento.

Deixando de lado os significados subliminares da advertência sobre os perigos do luxo, importa destacar as claras e contundentes demandas das intelectuais universitárias, feministas e socialistas que organizavam e participavam do Primer Congreso Femenino Internacional de la República Argentina: o acesso a uma educação igualitária que formasse mulheres capazes de lutar pela vida com seu próprio trabalho, aptas para reivindicar e exercer seus direitos civis e políticos, como cidadãs plenas (PRIMER CONGRESO, 1910/2008).

A demanda mais frequente, a respeito da leitura e da educação na formação das mulheres, no Primeiro Congresso Feminino, foi a de que o Estado ampliasse a educação primária das meninas e diversificasse a educação das moças. ${ }^{29}$ $\mathrm{Na}$ Sessão Educação, Letras, Artes e Indústrias, o Congresso Feminino solicita ao Estado o incremento do acesso e da

28. Esse ideal é expresso em vários trabalhos, às vezes de forma central e direta, outras de forma subjacente. Expressam a lógica argumental do imaginário da influência os trabalhos "La educación de la mujer. Su influencia moral en los destinos del hombre y de las naciones", de Modesta R. De Alanis Plaza (PRIMER CONGRESO, 1910/2008, p. 133-137); e "Influencia social de la madre”, apresentado pela Dr. ${ }^{a}$ Elvira Rodríguez Lorente, do Peru (PRIMER CONGRESO, 1910/2008, p. 202-213).

29. Lendo-se as atas dos dois congressos de mulheres realizados em 1910 entendese que havia, para as moças, o curso de Magistério e o de Enfermagem, provavelmente públicos, e as escolas de Economia Doméstica, particulares, de caráter não profissionalizante, destinados às senhoritas das classes privilegiadas. 
qualidade da educação primária das meninas e a criação de bibliotecas públicas "donde la mujer pueda encontrar libros que ensanchen su cultura" (1910/2008, p. 110). O mais inovador é que o Congresso demanda ao Estado a criação de Escolas Profissionais e Industriais para mulheres, que deem uma formação científica a técnica profissionalizante para a população feminina, a fim de que ela possa escolher uma profissão no comércio ou na indústria, que lhe garanta boa remuneração e a possibilidade de ter uma carreira profissional (1910/2008, p. 220). ${ }^{30}$

É importante constatar que, no Congresso Feminino, em 1910, o pleito pela educação das mulheres está presente desde os discursos de abertura, propondo a instrução como meio para a emancipação das mulheres, a fim de que tenham acesso ao mundo do trabalho, no comércio e na indústria, tenham independência financeira, autonomia e cidadania plena. Estas arrojadas demandas não foram imediatamente atendidas, mas foram discutidas e defendidas ao longo de todo o século XX, na Argentina e nas sociedades ocidentais. No próprio Congresso Feminino tais proposições foram enunciadas junto a outras que não tinham a mesma ousadia, que resistiam às proposições de que as mulheres, das classes populares e privilegiadas, ocupassem postos de trabalho que as desviassem das funções domésticas, de esposa e mãe.

No Primer Congreso Patriota de Señoras de América del Sud, realizado também em maio de 1910, em Buenos Aires, pelas damas da Sociedade Beneficente, representantes da oligarquia, do pensamento católico e conservador, houve a inflamada oposição ao feminismo, ao socialismo, ao

30. Em minha pesquisa de pós-doutorado, em 2018, na Universidad Nacional de Córdoba, não encontrei informações para confirmar se houve a criação das Escolas Profissionais e Industriais para mulheres na Argentina. Contudo, é preciso ampliar a pesquisa para ter uma conclusão definitiva. 
anarquismo e, inclusive, ao sufrágio feminino ${ }^{31}$. As Senhoras Patriotas defendem, em seus trabalhos, que as mulheres têm uma missão de influência sobre o caráter dos homens, dos filhos e da pátria, por isso reivindicam que sejam melhor educadas. Propõem que a educação prepare melhor as mulheres para exercer os "deveres sagrados de esposa e mãe" (1910/2012, p. 13). Pensando assim, demandam ao Estado que se amplie e se modernize em toda a nação o ensino de Economia Doméstica $^{32}$.

Nesse contexto é apresentada a censura contra os perigos do luxo, que "van tomando el carácter de una verdadera epidemia”, alerta a Sr. ${ }^{\text { }}$ Maria Emilia Beltrán Posse (2012, p. 200). Para eliminar o veneno da frivolidade e o efeito tóxico do luxo, ela propõe o programa corpo forte em alma forte, com vistas a promover a cultura ilustrada das mulheres e a prática de exercícios físicos. A Sr. ${ }^{a}$ Beltrán Posse advoga que:

La mujer ilustrada de conciencia sana, resistente a todas las tentaciones, será también la madre ejemplar, la conservadora de su hacienda, que desempeñe dignamente su rol de economía doméstica en el hogar. (...) Y es allí, en ese pequeño teatro de abnegaciones y mudos heroísmos donde quiero verla imperar como soberana, por su espíritu cultísimo, por su fortaleza en la lucha ordinaria de la vida (SEÑORAS PATRIOTAS, 1910/2012, p. 203).

31. Veja-se o trabalho de Elia M. Martínez, secretária do Congresso, em que está a declaração mais contundente contra o sufrágio para as mulheres (SEÑORAS PATRIOTAS, 2012, p. 236-250).

32. Um bom exemplo é o trabalho da Sr. ${ }^{a}$ Rosario Vera Peñalosa, em que propõe que as mulheres recebam desde a educação primária até a universidade uma formação "de carácter especialmente femenino" para cumprir sua missão como esposa e mãe, através de disciplinas ou de cursos de extensão sobre economia doméstica e puericultura (SEÑORAS PATRIOTAS, 2012, p. 116-124). 
Ainda que não haja uma comparação explícita, podese dizer que esse ideal feminino, expresso pela congressista, representa a figura oposta ao modelo censurável de Ema Bovary e de suas herdeiras argentinas, posto que as protagonistas dos romances não resistem às tentações, são infelizes no teatro das abnegações domésticas e negam-se a protagonizar mudos heroísmos.

Note-se que as proposições da Sr. ${ }^{a}$ Posse não demandam do Estado medidas para que se concretize em escolas ou universidades seu projeto de corpo e mente sãos. A reprovação ao vício do luxo pode ser entendida, então, apenas como um discurso moralizante, que se destina a ser publicado nos periódicos que cobriam o evento das patriotas ${ }^{33}$, censurando a frivolidade de suas congêneres das classes privilegiadas, exaltando a maternidade e a dedicação ao lar. Seu aplauso às mulheres que atuam no teatro das abnegações do retiro doméstico pode ser considerado uma defesa do modelo das Senhoras Patriotas, que se julgam cultas e virtuosas rainhas do lar, formadoras das famílias prestigiadas da elite, contrárias ao feminismo, ao divorcio e ao voto.

Enfim, cabe perguntar: quem tem medo de Ema Bovary e o manifesta censurando o luxo no século XIX e na primeira década do século XX, na Argentina? Considerando o texto jornalístico, o romance e as atas dos congressos,

33. Curiosamente o último capítulo das Actas del Primer Congreso Patriótico de Señoras en América del Sud recopila a série de notícias sobre o congresso que foram publicadas nos periódicos nacionais e estrangeiros que cobriram o evento. Muitas destas publicações trazem uma síntese dos discursos e trabalhos apresentados. Entre os periódicos argentinos estão La Nación, El Pueblo, La República, La Razón, Sarmiento, El Diario, La Prensa, El Nacional, La Argentina. Entre os estrangeiros encontram-se os espanhóis El País, El Diario Español e o francês Le Courrier Français (SEÑORAS PATRIOTAS, 1910/2012, p. 297-367). 
pode-se dizer que todos os grupos políticos e ideológicos mencionados a temem, por diferentes motivos.

Os discursos dos jornalistas, Alberdi e Tobal, bem como o moralizante romance El Lijo, de Lola Larrosa, do século XIX, em grande parte se assemelham aos preceitos dos pregadores católicos dos séculos XVI e XVII, pelo conservadorismo de suas proposições, posto que, em seus textos recomendam que as mulheres não se afastem de sua tradicional função de esposa e mãe, sublimam as virtudes da dedicação exclusiva ao universo doméstico e familiar, sugerem que as mulheres leiam e desejem apenas o que possa ser útil para construir a felicidade no lar.

$\mathrm{Na}$ primeira década do século XX, compreendese que as feministas e sufragistas do Congresso Feminino Internacional defendem certa retidão de caráter para que as mulheres de todas as classes sociais deem provas de sua capacidade intelectual, mostrem à sociedade sua aptidão para os estudos e o trabalho, provem que estão aptas para exercer a plena cidadania, votar e candidatar-se a cargos públicos, de modo a participar ativamente dos espaços de poder e das decisões que norteiam a vida em sociedade.

Tratando-se das Senhoras Patriotas, o rechaço às condutas desafiadoras de Ema Bovary, em particular o gosto pelo luxo e todo o subsequente imaginário que produzia, parece reforçar a defesa do modelo patriarcal de esposa e rainha do lar, isto é, da esposa casta, obediente ao marido, mãe exemplar, que participa da sociedade apenas ao dedicar-se à beneficência. Pode-se considerar que as senhoras de famílias oligarcas atacam as admiradoras e herdeiras de Ema Bovary para defender seu próprio modo de vida conservador, a fim de enaltecer e preservar as tradicionais estruturas de poder, das quais provêm os privilégios econômicos e políticos de 
sua classe e, em última instância, os valores que garantem o seu status social.

Pode-se concluir que nos congressos argentinos de 1910 a promoção da educação das mulheres é defendida, incrementando as campanhas pela leitura e a educação das mulheres ocorridas no século anterior. O congresso das feministas, obviamente, traz distintas diretrizes políticas para a educação das mulheres, com vistas a sua emancipação. Ainda que o imaginário sobre o luxo, proveniente dos romances que imitam a voluptuosa Madame Bovary, permeie alguns discursos e projetos enunciados no Congresso Feminino, parece indicar uma mudança de pensamento em curso, demonstrando que não é simples ou rápido desconstruir tradições enraizadas durante séculos no pensamento e nas práticas sociais.

Por fim, espera-se que este panorama mostre a jovens e também a experientes leitoras e leitores, através destes breves recortes no tempo e no espaço, que há vasta tradição na leitura qualificada e na escrita feita por mulheres, desde a Antiguidade e do tempo das mártires católicas, como Santa Catarina de Siena, apesar da igualmente vetusta tradição do controle masculino da leitura e da educação das mulheres. Há tradição no entendimento de que uma nação bem desenvolvida se constrói com mulheres leitoras e instruídas, como defenderam homens e mulheres intelectuais na Argentina do século XIX. Há tradição na luta pelo reconhecimento das amplas capacidades das mulheres, especialmente a partir do início do século XX, com o advento do movimento feminista, assim como há uma extensa tradição na busca de meios para viabilizar a desconstrução dos preconceitos, particularmente através das históricas demandas pela educação igualitária, pelo acesso equitativo ao trabalho, à plena cidadania e aos 
bens culturais, benefícios que a leitura e a boa educação precisam promover.

\section{REFERENCIAS}

ALCALÁ GALÁN, Mercedes. Escritura desatada: poéticas de la representación en Cervantes. Alcalá de Henares: Centro de Estudios Cervantinos, 2009.

BATTICUORE, Graciela. Lectoras del siglo XIX. Imaginarios y prácticas en la Argentina. Buenos Aires: Ampersand, 2017.

CERVANTES, Miguel de. El ingenioso hidalgo don Quijote de la Mancha. Edición, introducción y notas de Martín de Riquer. Barcelona: Planeta, 1990.

CRESPO, Natalia. Representaciones del hogar rural en Margarita (1875) de Josefina Pelliza y El lijo (1889) de Lola Larrosa. Revista Taller de letras $\mathrm{N}^{\circ}$ 58, 141-157, 2016. Disponible en:

file://C:/Users/User/Documents/Quem\%20tem\%20medo\%20 de $\% 20$ Emma $\% 20$ Bovary/Art\%C3\%ADculo\%20El\%20Lujo, \%20 vivienda\%20rural.pdf Acceso: 11/7/2019

FLAUBERT, Gustavo. Madame Bovary (1857). Tradutor não identificado. São Paulo: Clube do livro, 1944.

GUERRA, Vanessa. Prólogo. In: LARROSA, Lola. El Lujo. Disponible en: https://coleccionlasantiguas.blogspot.com/2013/01/el-lujo-de-lolalarrosa.html Acceso: 28/7/2019.

IFE, B. F. Lectura y ficción en el Siglo de Oro. Traducción Jordi Ainaud. Barcelona: Crítica, 1992.

LEÓN, Fray Luis de. La perfecta casada (1583). 9. ed. Madrid: Espasa Calpe, 1968.

LOBATO, Mirta Zaida. Historia de las trabajadoras en Argentina: 1869-1960. Buenos Aires: Edhasa, 2007.

ORTEGA Y GASSET, José. Meditaciones del Quijote (1914). Disponível em: Centro Virtual Cervantes https://cvc.cervantes.es/ literatura/quijote_antologia/ortega.htm Acesso: 27/7/2019

PEREIRA, Affonso Celso Thomaz. "Estado e Modernidade em Alberdi e Sarmiento". Anais do XXVI Simpósio Nacional de História ANPUH. São Paulo, junho, 2001. 
Disponível em: http://www.snh2011.anpuh.org/resources/ anais/14/1300658654_ARQUIVO_textoanpuh.pdf Acesso: 7/6/2021

PRIMER CONGRESO FEMENINO INTERNACIONAL DE LA REPÚBLICA ARGENTINA (1910). Prólogo de Dora Barrancos, Córdoba - A.R.: Universidad Nacional de Córdoba, 2008.

SALES, Francisco de. Introducción a la vida devota (1608). Traducción al español de Francisco de Quevedo (1634). In: QUEVEDO, Francisco. Obras completas. Edición, introducción y notas de Felicidad Buendía. Madrid: Gredos, 1992, p. 1740-1906.

SALAZAR RINCÓN, Javier. El mundo social del “Quijote”. Madrid, Gredos, 1985.

SÁNCHEZ LORA, José L. Mujeres, conventos y formas de la religiosidad del Barroco. Madrid: Fundación Universitaria Española, 1988.

\section{SANTO GREGÓRIO NAZIANZENO}

Disponível em: http://www.arquisp.org.br/liturgia/santo-do-dia/santogregorio-nazianzeno. Acesso: 2/6/21

SEÑORAS PATRIOTAS ¿O REACCIÓN OLIGÁRQUICA? ACTAS DEL PRIMER CONGRESO PATRIÓTICO DE SEÑORAS EN AMÉRICA DEL SUD, 1910. Jaqueline Vassallo et. al. (coord.). Córdoba - A.R.: Universidad Nacional de Córdoba, 2012.

VIGIL, Mariló Dolores. La vida de las mujeres en los siglos XVI y XVII. 2. ed. Madrid: Siglo XXI, 1994.

VIVES, Juan Luis. Formación de la mujer cristiana (1523). In: Obras completas. Organización de Lorenzo Riber. Madrid: Aguilar, 1947. 


\title{
CAPÍTULO 2
}

\section{EL ATREVIMIENTO DE TRES ESPAÑOLAS DEL SIGLO XVII}

\author{
René Aldo Vijarra \\ (Universidad Nacional de Córdoba)
}

A lo largo del siglo XVI, una serie de tratados morales y científicos pusieron su mirada en el cuerpo y la espiritualidad femenina. Ese conjunto de ideas intentó imponerse a lo largo del tiempo con el objetivo de ejercer un control sobre las mujeres, sin embargo, aparecieron voces disidentes con esos pensamientos. En este espacio describiré brevemente la representación de mujer llevada a cabo por un grupo de pensadores provenientes de diversos campos del conocimiento y, luego, presentaré el posicionamiento de tres escritoras españolas: María de Zayas y Sotomayor (1590-1661), Mariana de Carvajal (1600-1664) y Ana Caro (primera mitad del XVII). Cada una de ellas discrepó con los saberes imperantes sobre la mujer y se atrevió a ofrecer a los lectores y espectadores unas historias con personajes femeninos que se desplazan de la norma y se apropian de sus vidas. En otras palabras, una es la performatividad elaborada en el discurso patriarcal y otras son las mujeres presentadas por las tres escritoras.

Cada mujer concreta vive no sólo de acuerdo a sus condiciones materiales de vida, sino también, a partir de 
ser aprehendida desde una construcción teórica sobre lo femenino (MARCELA LAGARDE, 2005). No obstante, siempre existe la posibilidad de desplazamiento de esa representación legitimada y performadora y ese corrimiento de la norma abre la posibilidad de resistencia al modelo normativo ${ }^{1}$. Por eso es imprescindible distinguir -como propone MONIQUE WITTIG (2006) - entre "la mujer" y "las mujeres", teniendo en cuenta que la primera es solo una formación imaginaria, una construcción política e ideológica que niega a "las mujeres", su condición de sujeto y las limita a una relación de servidumbre ${ }^{2}$. En la misma línea de pensamiento, BUTLER sostiene que la categoría mujer es normativa y excluyente, y ha negado "la multitud de intersecciones culturales, sociales y políticas en que se construye el conjunto concreto de 'mujeres"' (2007, p. 67). En nuestro caso, una representación de "mujer" se inscribe en los discursos médicos, morales, jurídicos e, incluso, literarios en los siglos XVI y XVII, sin embargo, una diversidad de mujeres no concuerdan con el modelo y hasta se atreven a adoptar una actitud política de disidencia.

Para negar la condición de sujeto pleno a las mujeres, el discurso científico, el pensamiento filosófico y la moral cristiana del siglo XVI establecieron una representación de mujer con determinados atributos biológicos $\mathrm{y}$

1. La performatividad debe entenderse como una práctica reiterativa y referencial de interpelación y reprimenda mediante la cual el discurso produce los efectos que nombra, regula e impone: "Los actos performativos son formas del habla que autorizan la mayor parte de las expresiones performativas, por ejemplo, son enunciados que, al ser pronunciados, también realizan cierta acción y ejercen un poder vinculante” (BUTLER, 2002, p. 316).

2. "Lo que constituye a una mujer es una relación social específica con un hombre, una relación que hemos llamado servidumbre, una relación que implica obligaciones personales y físicas y también económicas (asignación de residencia, trabajos domésticos, deberes conyugales, producción ilimitada de hijos, etc.)" (WITTIG, 2006, p. 43). 
precisas funciones sociales definidas a partir de cualidades universales e iguales para todas. No obstante, otras fueron las mujeres representadas por el discurso de quienes se atrevieron a discrepar con las verdades consagradas por las voces patriarcales. Esa divergencia entre la representación normativa de mujer y las mujeres disconformes con la norma se manifiesta, por ejemplo, en la narrativa zayesca. La mayoría de los personajes femeninos de Zayas ejecuta una serie de prácticas, que los diversos tratados de la época intentan controlar, como leer, escribir, tocar algún instrumento y hasta hablar demasiado.

Con la llegada de Humanismo se anunciaban nuevos tiempos para España y los cambios en la vida política, comercial, social y cultural abrían la posibilidad de mirar el mundo desde otras perspectivas, no sin la resistencia de algunos sectores de la sociedad. Ya en el siglo XVI, los sujetos se reconocían seres individuales, sujetos de pensamiento y de pasiones y "sujetados" a rígidas normativas civiles y morales. Para entonces, el control sobre el cuerpo y la vigilancia en la formación moral e intelectual de las mujeres se convirtió en un espinoso dilema para confesores, moralistas, médicos, filósofos y varones responsables del grupo familiar.

Obras como Instrucción de la mujer cristiana (1528) del doctor Juan Luis Vives, o La perfecta casada (1583) de fray Luis de León, o Compendio del Manual de confesores y penitentes (1586) del teólogo Martín de Azpilcueta, o Examen de ingenios para las ciencias (1575) del doctor Juan Huarte de San Juan colaboraron en la configuración de la española del Siglo de Oro. Estos discursos relacionados unos con otros performan una representación de mujer como un sujeto biológicamente "flaco" y, en consecuencia, necesitado de una guía orientadora para su vida. El poder político y la política 
eclesiástica justifican la debilidad femenina por medio de un sistema de carencia:

- carencia biológica (debilidad física / incapacidad para el trabajo).

- carencia racional (incapacidad para crear / falta de ingenio).

- carencia de individuación (condenadas a la "indiscernibilidad"3 de una posición).

- carencia de completitud (varón no logrado).

- carencia genealógica (solo el varón legítima la genealogía al ser imagen y semejanza de Dios).

Con este régimen de privación se pretende justificar la sujeción de la mujer al varón y disciplinar su cuerpo, pensamientos y emociones. $\mathrm{E}$ incluso, como sostiene FOUCAULT determinar "a cada individuo su lugar, y a cada emplazamiento un individuo" (2012, p. 130).

Detrás de expresiones afectivas como "proveer de algún aviso" / "tiene necesidad de guía" manifestadas por fray Luis o la cariñosa contención declarada por el doctor Vives con términos como "hija mía" / "con celos de padre" se ocultan las duras restricciones impuestas a la mujer. Por un lado, se la somete a una serie de funciones y, por otro, se clausura la posibilidad de cualquier tipo de desplazamiento de la norma, lo que implica ponerlas "en-claustro", ya sea doméstico o conventual. El sistema de ideas del Antiguo Régimen normativizó el estado de doncella, casada, viuda y monja haciendo de cada uno de ellos verdaderos claustros femeninos y, como dice FOUCAULT, "lugares de encierro

3. Término utilizado por Celia AMORÓS PUENTES para indicar el espacio propio de las mujeres ya que no hay nada para adjudicarles, "y la carencia de razón suficiente para la individuación en el caso de la mujer es clara: no hay que repartir ni distribuir ningún patrimonio (valores, poder, reconocimiento, prestigio ontológico)" (2005, p. 105). 
heterogéneo a todos los demás y cerrado sobre sí mismo" (2012, p. 129).

Durante el siglo XVII, el siglo del desengaño y la melancolía, hombres y mujeres van perdiendo la confianza racional en los metarrelatos salvadores (RODRÍGUEZ DE LA FLOR) ${ }^{4}$. Y algunas mujeres se atreven a dar un paso y expresar su disconformidad con las falacias de la discursividad hegemónica patriarcal que las sujeta a esos "metarrelatos" condenatorios y disciplinadores. Esas mujeres barrocas se permiten dudar, cuestionar y resistir los valores sociales reglamentarios, la ciencia normalizadora y la moral censuradora inscripta en los "metarrelatos" consagrados con el costo de ser consideradas locas, osadas, atrevidas.

\section{LA MUJER HILE, COSA O LABRE Y, ¿TAMBIÉN, LEA?}

Más allá de la larga tradición patriarcal que habla de la imposibilidad de las mujeres de acceder al conocimiento, algunos humanistas del siglo XVI consideran imprescindible la formación intelectual y moral de ellas. El tratado viveseano, Instrucción de la mujer cristiana, promueve la formación de la mujer por medio de la lectura vigilada y orientada a "aquella parte de la doctrina que la enseña virtuosamente a vivir, $y$ pone orden en sus costumbres y crianza y bondad de su vida [...]" (VIVES, 1940, p. 30).

4. "El barroco apunta a un cambio trascendental del marco político y, con ello, a una remodelación absoluta del plano de la subjetividad, siendo alumbrada en aquellos tiempo una nueva conciencia, un nuevo sujeto, al que podemos llamar 'barroco', justamente porque con él emerge una configuración de lo psicosocial caracterizada, como es bien reconocido, por el rompimiento de las relaciones analógicas y la apertura a un mundo infinito e indeterminado, donde el sujeto pierde la confianza racional en los metarrelatos salvadores" (RODRÍGUEZ DE LA FLOR, 2012, p. 105). 
El doctor Vives entiende que por medio del aprendizaje la mujer podría superar su "malicia natural", y reconoce que hay doncellas inhábiles para las letras, en cambio hay otras que son hábiles para aprender a "las primeras no se debe apremiar a que aprendan, las otras no se han de vedar, antes se deben halagar y atraer a ello y darles ánimo a la virtud a que se inclinan" (VIVES, 1940, p. 21). Si bien Vives postula la educación de la doncella, de ningún modo es una formación intelectual o una formación habilitante para alguna actividad pública dado que en la concepción de la época la morfología corporal femenina -frialdad y humedad- no es compatible con el acceso al conocimiento. El peligro proviene de la complexión fría, ya que el frío endurece, paraliza, fija y, en una naturaleza débil como la femenina, "las ideas se quedan inmóviles en el cerebro y esta fijación de ideas es la que genera la tozudez femenina" (CACHO, 2012, p. 186). Y, por si esto fuera poco, podría aparecer algún pensamiento pecaminoso producto de la ausencia de calor.

"Aprenderá, pues, la muchacha, juntamente letras, hilar y labrar, que son ejercicios muy honestos (...)" (1940, p. 16), sostiene VIVES, sin embargo, la lectura solo es válida si tiene un fin moral. Más allá de la práctica piadosa de la lectura, ésta se vuelve sospechosa a la mirada de los educadores, quienes advierten sobre los efectos perniciosos de muchas obras "deshonestas". "Por tanto, la doncella se debe guardar de leer en vanidades" (1940, p. 39), amonesta VIVES, y destierra de la formación femenina a todos los libros de caballerías, la Celestina, "alcahueta madre de las maldades", la lírica amorosa y enumera los libros que se deben leer: evangelios, epístolas, viejo testamento, San Agustín, San Jerónimo, etc.

Con la expresión aprender letras se hace referencia al aprendizaje de la lecto-escritura. Sin embargo, los educadores 
ponen más énfasis en enseñanza de la lectura formadora y menos en la práctica de la escritura dado el potencial peligro de expresar las ideas propias ${ }^{5}$. Para entonces, leer y escribir no eran prácticas íntimamente ligadas como las entendemos hoy y el hecho de que una mujer pudiera leer no implicaba que supiera escribir. Incluso, la mayoría de las mujeres no sabía leer lo que no supone que quedaran al margen de la cultura (BARANDA LETURIO, 2005) ${ }^{6}$.

El Compendio del Manual de confesores de Martín de Azpilcueta es un texto dirigido especialmente a confesores, así mismo ofrece una imagen femenina. En líneas generales, la obra del teólogo se alimenta de la misma tradición intelectual que nutre al doctor Vives y a fray Luis, aunque con una posición más benigna en lo que respecta a la mujer. En referencia a la lectura "siempre es pecado, al menos venial (...) del que lee, u oye libros de amores, y de cuentos lascivos" (AZPILCUETA, 1586, p. 139). Es lo mismo que se viene sosteniendo, si la lectura no es formativa no es útil. Y como todo moralista sentencia: "Por lo cual sería bien vedar que algunos libros de Ovidio, de Juvenal, Marcial y Propercio, y de otros, no se leyesen en las escuelas (...) y un libro que llaman Celestina tan aprobado por el vulgo, no se dejase leer o gran parte de él se quitase (AZPILCUETA, 1586, p. 139).

5. "Cuando le enseñaren a leer, sea en buenos libros, que toda agua no es de beber, y cuando le mostraren a escribir, no le den materia ociosa o vana, sino alguna cosa sacada de la Sagrada escritura, (...) la cual, escribiéndola una y muchas veces, se le imprima firmemente en la memoria” (VIVES, 1940, p. 30).

6. "Ahora bien, no saber leer en una sociedad donde no lo hace la mayoría de sus miembros, no implica para esas mujeres vivir al margen de la cultura del escrito, que adquieren por vía oral a través de cauces variados: en el hogar con las lecturas en voz alta, en la iglesia por medio de los sermones, en la calle a través de los cantares, la recitación o la lectura pública, en el claustro, etc." (BARANDA LETURIO, 2005, p. 21). 
En La perfecta casada, fray Luis de León también se dedicó a delimitar las tareas que debe desempeñar una esposa cristiana. El hilo y la rueca "son como las armas y el campo donde descubre su virtud la buena mujer" (LEÓN, 1999, p. 32). Entre las funciones primordiales no figura la lectura, sin embargo, el fray agustino tampoco niega la posibilidad, aunque exhorta a los maridos a "que las excusen y libren de leer en los libros de caballerías, y del traer del soneto y la canción en el seno, y del billete del donaire de los recaudos" (LEÓN, 1999, p. 36). La lectura se torna peligrosa si es profana o si solo sirve para solaz y, en última instancia, para qué leer si "la naturaleza no la hizo para el estudio de la ciencia, ni para los negocios de dificultad, sino para un solo oficio simple y doméstico, así les limitó el entender y, por consiguiente, les tasó las palabras y las razones" (LEÓN, 1999, p. 72). Fray Luis sostiene su pensamiento sobre la naturaleza débil y la inferioridad intelectual de la mujer. Sin embargo cree que en forma excepcional logra superar la simpleza natural y, de haber algún caso anómalo de mujer ingeniosa, la llama "mujer varonil". En otras palabras, la mujer pensante se equipara al varón, por lo tanto, casi pierde su condición femenil.

Según el Examen de ingenios, "la razón de tener la primera mujer no tanto ingenio le nació de haberla hecho Dios fría y húmida, que es el temperamento necesario para ser fecunda y paridera, y el que contradice al saber (...) (HUARTE DE SAN JUAN, 2005, p. 614). Desde el principio de los tiempos, la mujer tuvo impedida la posibilidad de alcanzar el conocimiento por mandamiento divino, por un lado, y por otro, debido a causas naturales: la frialdad y humedad. Dos fundamentos de peso que sirven para justificar su condición de inferioridad y la consecuente exclusión de la condición de sujeto pleno con todo lo que esto implica: exclusión del espacio público y enclaustramiento doméstico 
o monacal. En el modelo huarteano de mujer es innecesaria la posesión del conocimiento porque "quedando la mujer en su disposición natural, todo género de letras y sabiduría es repugnante a su ingenio" (HUARTE DE SAN JUAN, 2005: 615). Solo le reconoce la facultad de memorización de "materias livianas y fáciles" y la repetición de un poco de latín para los rezos diarios.

En síntesis, a lo largo del siglo XVI existe una preocupación por la educación femenina y desde la mirada institucional de la iglesia y de la ciencia se valida una limitada formación solo si sirve para controlar el cuerpo, formar el pensamiento y orientar el alma de la mujer.

\section{LOCAS, OSADAS, ATREVIDAS}

Josefina LUDMER (1985) sostiene que uno es el espacio que la mujer se da y ocupa, y otro es el lugar que las instituciones y la palabra del otro le otorgan. Ante esta discordancia, "la treta (otra típica táctica del débil) consiste en que, desde el lugar asignado y aceptado, se cambia no sólo el sentido de ese lugar sino el sentido mismo de lo que se instaura en él" (LUDMER, 1985, p. 43). María de Zayas, Ana Caro y Mariana de Carvajal no se contentan con el lugar asignado en el campo socio-cultural aunque aparenten aceptarlo con humildad. A su modo, cada una pretende posicionarse en el campo cultural dominado por el poder hegemónico masculino. Muy sutilmente, ellas intentan manifestar, en primer término, su disidencia con quienes pretenden poner en claustros su destino a partir de principios biológicos universales $y$, en segundo término, procuran un lugar como 
mujeres con un saber-hacer en un campo tradicionalmente vedados para ellas, el campo literario ${ }^{7}$.

Zayas, en el prólogo a sus Novelas ejemplares y amorosas (1637), es consciente de que se arriesga a ser considerada un ser abyecto: "Quién duda, digo otra vez, que habrá muchos que atribuyan a locura esta virtuosa osadía de sacar a luz mis borrones, siendo mujer (...) (ZAYAS, 2017, p. 15). Para FOUCAULT, el loco es el otro en relación a los demás y el otro es la excepción entre los otros en el sentido de lo universal. "Bajo la mirada de la razón: la locura es individualidad singular cuyos caracteres propios, cuya conducta, cuyo lenguaje, cuyos gestos se distinguen uno a uno de lo que puede encontrarse en el no loco" (FOUCAULT, 1967, II, p. 17). Desde el lugar de la razón, desde la perspectiva del hombre como "medida de todas las cosas", desde la mirada patriarcal de los "metarrelatos" disciplinadores, la locura consiste en ingresar al espacio prohibido para ellas y tener la osadía no solo de escribir, sino también, de publicar sus escritos. Hacer pública su voz contraviene el silencio recomendado a la mujer y convierte a doña María en "loca”.

La misma suerte podría correr Mariana de Carvajal, dado que es una atrevida al optar por la pluma y no por la rueca o el bastidor y, ella lo sabe, entonces, decide disculparse de antemano por su atrevimiento. En el breve prólogo a Navidades de Madrid y noches entretenidas, en ocho novelas (1663), dirigiéndose a su público, le dice: "Atento y curioso lector, aunque no me será posible el conseguir lucidos desempeños

7. BARANDA LETURIO sostiene que a pesar de la misoginia "se produce desde los primeros decenios del XVII la aparición pública de numerosísimas mujeres, que escriben en justas o que se atreven a editar su obra" (2005, p. 31). Si bien es cierto que fue aceptada la participación femenina en justas poéticas, sin embargo, no ocurrió lo mismo con la posibilidad de publicar sus composiciones. 
en el arresto de tan conocido atrevimiento (...)" (CARVAJAL, 1993, p. 5).

El Tesoro de la Lengua Castellana de define osar como atreverse y osado es el audaz, el atrevido (COVARRUBIAS, 1995, p. 791). Atrevido es "el determinado y arrojadizo en acometer una cosa sin considerar primero lo que se podría seguir de hacerla" (COVARRUBIAS, 1995, p. 137). La osadía y atrevimiento de Zayas y de Carvajal las anima a "acometer" al orden establecido, tal vez, sin tener en cuenta las consecuencias de ser estimadas como unas locas. Para Zayas la "inclinación" es el impulso movilizador, que la induce a practicar la escritura. En el caso de Carvajal, el "arresto", es decir, una fuerte determinación para llevar adelante el "desempeño" de una práctica para la cual ella no está habilitada. En ambas, el tener que decir y saber cómo manifestarlo se transforma en una irresistible fuerza natural, que las alienta a transgredir el orden y, más allá de la valoración de los otros, se animan a escribir y hasta publicar.

Por otro lado, la aparente humildad de doña Mariana al escribir que "no me será posible el conseguir lucidos desempeños" (CARVAJAL, 1993, p. 5) acaba por hacerse poco confiable, dado que promete brindar algo sin valor, entonces cabría preguntarse para qué ofrece lo que carece de atractivo. Y por si fuera poco agrega que estará "atenta a tan prudente corrección” (CARVAJAL, 1993:5). La escritora utiliza estratégicamente el tópico la "modestia afectada" que muestra a los otros la humildad antes que la vanidad, la sumisión frente al dictamen de los hombres, el sometimiento y nunca la rebeldía. Estas son las "tretas de las débiles" y, como sostiene LUDMER (1985), el saber y el decir son dos acciones que comportan castigo para la mujer. Ante las posibles represalias, la "treta" consiste en hacerle creer que a 
"este pequeño libro" le falta calidad y tiene "los defectos de una tan mal cortada pluma" (CARVAJAL, 1993, p. 5).

Los criados Tomillo y Ribete de Valor, agravio y mujer (1630/40), de Ana Caro, son fieles reproductores de la concepción patriarcal que niega a las mujeres la posibilidad de ingreso a un espacio diferente al definido por los varones. En otras palabras, hilar, coser y labrar son las actividades inherentes a la mujer y ellos no pueden entender o aceptar que una mujer escriba:

$\begin{array}{ll}\text { Tomillo } & \text { ¿Qué hay en el lugar [Madrid] de nuevo? } \\ \text { Ribete } & \text { Ya es todo viejo allá; } \\ & \text { sólo en esto de poetas } \\ & \text { hay notable novedad } \\ & \text { por innumerable, tanto, } \\ & \text { que aun quieren poetizar } \\ & \text { las mujeres, y se atreven } \\ & \text { a hacer comedias ya. } \\ & \text { ¿Válgame Dios! Pues ¿no fuera } \\ & \text { mejor coser e hilar? } \\ \text { Tomillo } & \text { ¿mujeres poetas? } \quad \text { (CARO, 1993, p. 115) }\end{array}$

Hasta en las capas más bajas de la sociedad producen cierto asombro los nuevos modos, usos y costumbres de la modernidad temprana. El gusto por la novedad es exaltado por ciertos grupos sociales de las urbes, sin embargo, desde los estratos más tradicionales miran con recelo toda manifestación de cambio al orden establecido ${ }^{8}$. Por ejemplo, Martín de Azpilcueta hace referencia al deseo por lo novedoso al que llama "vicio de la curiosidad" que se parece mucho con el "vicio de la invención": "Y que es vicio, que inclina a querer desordenadamente saber sobrado, o como

8. "El gusto por lo nuevo ni se presenta siempre bajo las mismas formas, ni con la misma fuerza capaz de mover el obrar humano, ni expandido con la misma extensión por las diferentes capas sociales" (MARAVALL,1986, p. 33). 
no debe, y que siempre es pecado, al menos venial (...)" (AZPILCUETA, 1586, p. 139).

Todo lo que se aparta de la norma consiste en novedad peligrosa. Para los grupos conservadores, coser, hilar, administrar el hogar, educar a los hijos y otras funciones ligadas al interior de hogar son las únicas posibles para la mujer. En cambio, un pequeño grupo de voces opositoras se atreve a ofrecer su mirada renovadora.

Para el orden social patriarcal del siglo XVII es un "atrevimiento" que la mujer incursione en el campo de las letras. La escritura, en general, y la ficción, en particular, eran un ámbito exclusivamente masculino, por lo tanto, son "atrevidas" las que transgreden, desobedecen y quebrantan "las virtudes debidas, el silencio y el hablar poco" (LEÓN, 1999, p. 71). La audacia se destaca más aún cuando el grupo disidente hace un uso explícito de las palabras "osadía", "atrevimiento", "loca" al presentarse al lector, u oyente o espectador. Atreverse implica desafiar la norma y cada una de las escritoras discrepa con el sistema demostrando que es capaz de desempeñar el oficio de la escritura. Y es por esto que Zayas considera que es una "virtuosa osadía".

\section{LOS DESENGAÑOS DE ZAYAS}

Desde los albores del siglo XVII, una serie de circunstancias sociales, políticas y económicas produjeron un sentimiento de inestabilidad individual y social, que se manifestó con un marcado pesimismo, con un imperioso deseo de cambio y un sostenido gusto por lo novedoso. Las mujeres no estuvieron ajenas a la pretendida renovación socio-cultural, todo lo contrario, participaron activamente como escritoras de novela, poesía y teatro, como libreras- 
imprenteras difundiendo las obras, como actrices en los corrales de comedia, como lectoras en la intimidad del hogar o espectadoras de la comedia nueva en los bulliciosos escenarios de la corte.

Una escritura innovadora por su desacuerdo con el poder patriarcal es la de María de Zayas. Su obra ofrece su posicionamiento político disidente con quienes pretenden sujetarlas a los "metarrelatos" performadores de la mujer perfecta. Se atreve a discrepar con los postulados de Huarte de San Juan al sostener que "quizá [ellas sean] más agudas, por ser de natural más frío, por consistir en humedad el entendimiento" (ZAYAS, 2017, p. 15). De este modo rebate el determinismo biológico huarteano al sostener que frialdad y humedad son fuente de entendimiento. Además, se inserta en la larga tradición de "querelles des femmes" abogando por una igualdad entre la mujer y el hombre. Para esto se apoya en los logros científicos sobre la materialidad de los cuerpos:

(...) si es una misma sangre; los sentidos,
las potencias y los órganos por donde se
obran sus efectos, son unos mismos; la
misma alma que ellos, porque las almas ni
son hombres ni mujeres: ¿qué razón hay
para que ellos sean sabios y presuman
que nosotras no podemos serlo? (ZAYAS,
2017, p. 15).

En cuanto a las funciones femeninas delineadas en los tratados, Zayas no dejó de señalar los mecanismos restrictivos del sistema patriarcal que solo las habilita para "el cambray en las almohadillas y los dibujos en el bastidor" (ZAYAS, 2017, p. 15). El acotamiento de las competencias femeninas expuesta en los diversos tratados tiene el objetivo de regular las prácticas relativas a la división sexual del trabajo. La escritora entiende que otras serían las posibilidades de las mujeres si les dieran "libros y preceptores". Probabilidad impensable en la 
mentalidad conservadora de los hombres perteneciente a los grupos de poder.

En la obra zayesca, muchos personajes femeninos han demostrado que "tienen el alma y las potencias y los sentidos como los hombres" (ZAYAS, 2017, p. 585), lo que les ha permitido exhibir su condición de sujetos pleno, apropiarse de sus vidas para no ser objeto de intercambio y ser sujetos en plena posesión de sus cuerpos y de sus prácticas. Sin embargo, la narrativa de la escritora presenta otros tantos personajes femeninos que son objeto de maltratos psíquicofísicos y hasta despojados de su condición humana?.

El esquema de las Novelas amorosas y ejemplares es bien conocido: un grupo de amigos/as se reúne para entretener a Lisis, quien padece "unas cuartanas" $y$, durante cinco noches, dos integrantes del contertulio relatan una "maravilla" cada uno $^{10}$. En Desengaños amorosos se repite el mismo esquema, con la diferencia que "habían de ser las damas las que novelasen" (ZAYAS, 2017, p. 433). La presencia masculina se desplaza y ese sitial es ocupado únicamente por voces femeninas, que durante tres noches contarán sus "desengaños".

9. Por ejemplo, en "Tarde llega el desengaño", don Jaime trata a su esposa como un animal hasta su muerte. Otro caso es el de Inés en "La inocencia castigada", en donde su cuerpo es degradado a condiciones infrahumanas.

10. Laura, quien preside el sarao, manda que "después de haber danzado, contasen dos maravillas, que con ese nombre quiso desempalagar al vulgo del de novelas, título tan enfadoso que ya en todas partes le aborrecen" (ZAYAS, 2010, p. 168). Julián Olivares interpreta que Zayas opta por el término "maravilla" dado el desgaste y desprestigio de la palabra "novela" pero, además, entiende que, para la escritora, la novela reproducía los valores patriarcales y "en oposición a novela, con los términos de maravilla y desengaño, Zayas seguramente quiso designar un discurso femenino dentro del género de la novela, que defendiese a la mujer y que representase una perspectiva femenina; y con ello rebelarse contra el dominante discurso masculino, cambiando las fórmulas y desestabilizando así la lectura de las novelas" (OLIVARES, 2017, p. LXV). 
El tópico sobre el engaño / desengaño se instala durante el Barroco en todos los órdenes de la vida. El desengaño surge como respuesta combativa al engaño con sus múltiples facetas y es, también, una postura ante la vida. "El desengaño deshace imágenes falsas, y con esfuerzo aniquila apariencias pudiendo hallar y penetrar en el escondido ser" (GRANDE YÁÑEZ, 2012, p. 69). Esto es lo que pretenden las narradoras-personajes del segundo sarao y, así, lo ponen de manifiesto, por ejemplo:

- Lisarda declara: "Mandásteme, hermosa Lisis, que fuese la segunda en dar desengaños a las damas de que deben escarmentar en sucesos ajenos para no dejarse engañar de los hombres" (ZAYAS, 2017, p. 489).

- Nise, la tercer narradora sostiene: “(...) para que las damas de estos tiempos estemos prevenidas con el ejemplo de las pasadas a guardarnos de no caer en las desdichas que ellas cayeron, por dejarse vencer de los engaños disfrazados en amor de los hombres" (ZAYAS, 2017, p. 521).

- Matilde, la sexta narradora manifiesta: "quiero granjear nombre de desengañadora, (...) que naturaleza nos afeminó, que ella, si nos dio flacas fuerzas y corazones tiernos, por lo menos, nos infundió el alma tan capaz para todo como la de los varones" (ZAYAS, 2017, p. 622).

- Francisca, la octava narradora declara: “(...) a los hombres no se les ha de creer sino es cuando dicen: domine, non sum dignus" (ZAYAS, 2017, p. 702).

$\mathrm{Y}$ así como estas, cada una de las participantes previene al auditorio sobre los engaños de los hombres. Los engaños / desengaños zayescos, no solo pretenden mostrar como el intelecto femenino es menospreciado y sus cuerpos 
convertidos en objetos de sometimiento y apropiación por el poder patriarcal, sino también, instan a desengañarse de las falacias de los "metarrelatos" condenatorios y disciplinadores.

La sujeción queda evidenciada en seis de los "desengaños" relatados, en donde las protagonistas son asesinadas de modo tiránico por la violencia masculina, ya sea de padre, hermano, marido o tío de las víctimas ${ }^{11}$. Esta mayoría de casos con funesto final no hace más que poner de manifiesto la concepción de mujer despojada de su condición de sujeto y formando parte de los bienes personales del varón. Sin embargo, sus trayectorias vitales no han sido en vano, ya que sus vidas o sus muertes trascienden para servir de ejemplo sobre los engaños de los hombres. Ese engaño consiste, en líneas generales, en hacerles creer a las mujeres que necesitan del hombre por su debilidad física, intelectual y moral. Y desengañarse de los "buenos" varones implica reconocer que quienes dicen cuidar de sus vidas las dominan, las maltratan y hasta las matan. Lo que para ellos es cuidado y orientación, para ellas es tiranía y dominación.

En la introducción a los Desengaños, la narradora propone la "reprensión" de quienes "olvidados de sus obligaciones hacen diferente de lo que es justo. Estos tales no serán hombres sino monstruos; y si todos lo son, con todos hablo, (...)" (ZAYAS, 2017, p. 434).

Para FOUCAULT, lo que define al monstruo es el hecho de que "en su existencia misma y su forma, no solo es violación a las leyes de la sociedad, sino también de las leyes de la naturaleza" (2007, p. 61).La monstruosidad aparece cuando "el desorden de la ley natural, trastorna, inquieta el derecho, ya sea derecho civil, el canónico o el religioso (FOUCAULT,

11. Asesinadas son: Camila (Desengaño segundo), Roseleta (Desengaño tercero), Elena (Desengaño cuarto), Laurela (Desengaño sexto), Blanca (Desengaño séptimo), Ana (Desengaño octavo). 
2007, p. 69). Tanto en las Novelas amorosas como los Desengaños amorosos se ha sostenido la idéntica naturaleza del hombre y la mujer: "la misma sangre; los sentidos, las potencias y los órganos" (ZAYAS, 2017, p. 15). La monstruosidad, precisamente, radica en el rechazo del patriarcado a esa ley natural y, por consiguiente, la negación de los derechos a las mujeres. El atrevimiento de Zayas consiste en amonestar a los hombres por su abuso de poder y, además, es una osada al llamarlos "monstruos". Sin embargo, su "treta" consiste en no generalizar, es decir, no se dirige a "los que no lo fueren (...), el hombre cuerdo, bien intencionado" (ZAYAS, 2017, p. 434), sino, solo a aquellos que violentan el cuerpo, la mente y el alma de las mujeres.

\section{NAVIDADES DE MADRID DE MARIANA DE CARVAJAL}

La obra ofrece ocho novelas cortas, cuyo marco narrativo es una tertulia doméstica, y cada uno de estos relatos compone una secuencia cerrada en sí misma. Los hechos suceden en la casa de doña Lucrecia de Haro y es allí cuando una vecina, doña Juana, propone entretener con festejos las frías noches previas a la Navidad: "Cada uno ha de quedar obligado a contar un suceso la noche que le tocare" (CARVAJAL, 1993, p. 17). Y será la misma doña Juana la encargada de repartir el orden de exposición entre quienes participarán de la velada.

La libertad de las protagonistas es un rasgo distintivo de las historias. Libertad que se manifiesta en los modos de vinculación social, en las decisiones sobre sus afectos y en las acciones para alcanzar sus cometidos. Shifra ARMÓN, en referencia a la narrativa de Carvajal, señala que "a primera vista 
esta libertad de movimiento parece anunciar la llegada de una nueva posición del sujeto, la del 'individuo' moderno” (2014, p. 351). Las y los narradoras/es de las historias ponen de manifiesto la ingeniosidad, la educación esmerada y la libertad de movimiento de las protagonistas. Por ejemplo, de Floripa de La Venus de Ferrara se dice que "preciábase de escribir algunos versos" (CARVAJAL, 1993, p. 28). De Matilde de El esclavo de su esclavo se enfatiza su "claro entendimiento" lo que la lleva a actuar en consecuencia. Lisena de Amar sin saber a quién "era tan clara y aguda de entendimiento que ponía en admiración a quien la escuchaba" (CARVAJAL, 1993, p. 186).

La "treta" de los personajes femeninos radica en demostrar sutilmente su capacidad para decidir sin confrontar con la autoridad masculina de padres, hermanos o tíos, quienes pretenderán imponer sus propios dictámenes. En otras palabras, en el escaso margen de elección de estado para toda la vida, ya sea el claustro doméstico o monacal, el matrimonio no es una opción, es casi una obligación y, por eso, ponen en acción algunas estrategias para alcanzar la propia voluntad. Lo novedoso de la narrativa de Carvajal se presenta en la decisiva participación de las mujeres en la elección del hombre que acompañará el resto de sus vidas.

En "Celos vengan desprecios", el conde Leonido y el duque Arnaldo desean alcanzar a Narcisa para llevarla al altar pero a ella no le interesa ninguno de los pretendientes. La insistencia de ambos se convierte en acoso y, ante esa situación recurre a la justicia para denunciar los hechos. El Virrey le da la razón pero "aquellos títulos eran tan poderosos que le obligaban a darse por desentendido, que lo llevase con prudencia, pues tenía tanta" (CARVAJAL, 1993, p. 120). Ante la acusación de Narcisa, la autoridad real ni quiere ni puede enfrentar a los poderosos, por lo tanto se le sugiere soportar. 
No contenta con la resolución y "por vengar su enfado los trataba con rigurosos desdenes" (CARVAJAL, 1993, p. 120). Finalmente triunfa porque entrega su "libre corazón" a un hombre elegido, don Duarte y le dice: "No fuera yo quien soy a no mostrarme agradecida" (CARVAJAL, 1993, p. 130). MARAVALL sostiene que "soy quien soy" es una fórmula que implica "el reconocimiento del albedrío, en el sentido moral, no político o social, esto es, la doctrina de la propia voluntad con que se asume un comportamiento" (1990, p. 64). En este caso, no solo hay una libertad de elección, también existe una actitud política al rehusar la solicitud de los nobles que pretenden doblegar su voluntad. Narcisa se revela contra el poder del conde Leonido y el duque Arnaldo y ambos quedan en la incómoda posición de hombres rechazados por una mujer.

La temática amorosa recorre la narrativa de Mariana de Carvajal, en donde aborda el espinoso tema de la libre elección del cónyuge. Mariló VIGIL sostiene que "a juzgar por el discurso de los moralistas, por la novela y por el teatro de la época, éste sí fue un derecho por el que ellas lucharon" (1986, p. 82). Si bien los personajes femeninos de Navidades de Madrid disfrutan del ritual del galanteo amoroso, ellas se desplazan del mero lugar de "objeto" deseado para posicionarse como sujetos con capacidad para gobernar sus destinos. En las diferentes historias, las futuras consortes deben moverse con habilidad entre los propios intereses y la normatividad social, que pretende sujetarlas al mandato patriarcal.

Doña Mariana fue doblemente "osada": primero por ingresar a un espacio vedado para ella y, segundo por reclamar el derecho a participar en la gestión del matrimonio y, de ese 
modo, ejercer una resistencia a la patrimonialización de los cuerpos de las mujeres.

\section{VALOR, AGRAVIO Y MUJER DE ANA CARO}

La escritora presenta una mujer agraviada, quien decide vengar con manos propias su deshonor. Don Juan seduce a Leonor con la promesa de ser su esposo pero la abandona después de consumado el amor ${ }^{12}$. Ella acompañada por Ribete, su criado, sale en busca del seductor y lo hace travestida de hombre: "En este traje podré / cobrar mi perdido honor" (CARO, 1993, vv. 464-465). Fingiendo ser Leonardo encuentra a su burlador en la corte de Bruselas, donde advierte que él está seduciendo a la condesa Estela. A partir de esta situación, la ingeniosa Leonor urde un plan de enredos hasta que finalmente hace público el hecho deshonroso, entonces don Juan decide cumplir la palabra dada.

Tópicos como ser / parecer, identidad, libertad, honra, entre otros, fueron verdaderas preocupaciones para hombres y mujeres barrocas. En Valor, agravio y Mujer, la dramaturga intensifica el conflicto de la deshonra de la protagonista con el desplazamiento consciente de la prescripción moral de la castidad y con el incumplimiento de las normas jurídicas.

La castidad como virtud es tratada por todos los moralista. Juan Luis Vives les recuerda a las doncellas que "lo primero y principal quiero que sepa la mujer cristiana que su principal virtud es la castidad, y que ésta sola es como

12. Los cánones del Concilio de Trento prohibían la extendida costumbre de la "promesa de matrimonio" o "matrimonio en secreto" y solo se consideraba válido el compromiso matrimonial ante testigos y el párroco de la comunidad. La unión matrimonial era competencia exclusiva de la Iglesia (VILLALBA PÉREZ, 2004). 
dechado y pendón real de todas las otras virtudes" (VIVES, 1940, p. 103). Para fray Luis de LEÓN, la honestidad es "guardar el cuerpo entero para el marido" (1999, p. 23) y consiste en el ser y sustancia de la mujer y el no ser honesta implica perder la condición femenil y convertirse en un sujeto marginal "porque si no tiene esto [honestidad], no es ya mujer, sino alevosa ramera y vilísimo cieno, y basura las más hedionda de todas y la más despreciada" (LEÓN, 1999, p. 24). La virginidad como atributo exclusivo y excluyente de la "buena" doncella no solo afecta a la propia honra femenina sino que atañe al reconocimiento social de todo el grupo familiar: padre, hermanos y al futuro marido. Un traspié de la doncella implicaba el derribamiento del honor familiar.

Leonor ha perdido su castidad, por lo tanto, es pecadora por atentar contra las normas morales y su condición se agrava por cometer "trato ilícito". La legislación sobre la moral sexual denominaba "trato ilícito" a "la fornicación simple entre hombre y mujer en disposición de poder casarse" (VILLALBA PÉREZ, 2004, p. 224). En la mayoría de los casos, el hombre realizaba una falsa promesa de matrimonio para persuadir a la supuesta amada y, una vez obtenido el goce, la promesa desaparecía. Así lo deja reflejado don Juan en su confesión:

\section{$(\ldots)$}

persuadí sus enterezas, solicité sus descuidos, facilité mis promesas.

Favoreció mis deseos, (...)

Díla palabra de esposo; no es menester que os advierta lo demás; discreto sois. (...) 
Cansado y arrepentido

la dejé, y seguí la fuerza,

si de mi fortuna no,

de mis mudables estrellas. (CARO, 1993, vv. 381-405)

Si bien Leonor es la víctima de la seducción y la agraviada de acuerdo al estricto código del honor, dicha situación no la libera del pecado cometido contra las prescripciones de la Santa Madre Iglesia ni del delito consumado contra el sistema jurídico ${ }^{13}$. El agravio a la virtud no solo provoca un sentimiento de humillación, además, implica el desplazamiento social. La conciencia de su delicada situación la anima a una inmediata búsqueda de esa honra perdida como parte constitutiva de su identidad:

¿Yo aborrecida y sin honra?

¿Tal maldad los cielos sufren?

¿Mi nobleza despreciada?

¿Mi casta opinión sin lustre?

¿Sin premio mi voluntad?

Mi fe, que las altas nubes

pasó y llegó a las estrellas,

¿es posible que las injurie

don Juan? ¡Venganza, venganza

cielos! (...). (CARO, 1993, vv. 856-865)

Desde su posición de transgresora a las leyes divinas y humanas decide travestir su condición de mujer para limpiar la mancha, que sobre ella pesa. El disfraz varonil le permite representarse con una identidad de género con estatuto de poder por el solo hecho de ser varón, sin embargo, previo al disfraz, ella ha tenido la firmeza para defender su propia honra.

13. Con respecto al status jurídico de la mujer, todas las referencias legales respecto a ellas están en relación a los hombres, ya sean padres, hermanos o maridos lo que las ubica en un lugar de subordinación (VILLALBA PÉREZ, 2004). 
La dualidad, muy al gusto barroco, entre el ser y parecer genera cuestionamientos íntimos: "Yo, ¿’soy quién soy? / engáñaste si imaginas / Ribete, que soy mujer; / mi agravio mudó mi ser" (CARO, 1993, vv. 507-510), dice Leonor. El conflicto identitario de la protagonista transita de lo individual / privado a lo social / público debido a que como mujer engañada ya no es doncella, pero tampoco es la "casada perfecta", al no existir el reconocimiento social y público del matrimonio. Además, el agravio la desplaza del espacio privado para conducirla al espacio público donde se empodera para defender su condición de mujer. La "mudanza de su ser" es el resorte dramático que impulsa la acción para la consecución de una meta: obtener el reconocimiento de esposa, al que tiene derecho por la promesa matrimonial del falso don Juan.

Leonor no solo transgrede el código del honor al aceptar voluntariamente entregarse al seductor, sino también, al reivindicar el derecho a la venganza por manos propias sin la participación masculina. De este modo, se manifiesta como una mujer con fuerza y decisión para modificar su condición de deshonrada y, además, sus acciones muestran que no necesita de un hombre para lograr sus fines.

Leonor es una mujer con fortaleza, pasión e ingenio para llevar adelante su proyecto vital, Además, con clara conciencia del valor social de su honor y así lo pone de manifiesto en un monólogo del segundo acto: “i(...) Ay, honor, / qué me cuestas de pesares / qué me debes de zozobras, / en qué me pones de ultrajes!" (CARO, 1993, vv. 1308-1311). En todo este periplo, ella debe comportarse con actitudes masculina de las que disiente: arrogancia, falsedad, 
ocultamiento y, como dice BUTLER (2002), está obligada a "citar la norma" para que se la considere un sujeto viable ${ }^{14}$.

Si el discurso patriarcal considera a la mujer sujeto únicamente de pasión, aquí la mujer travestida exhibe lo contrario e, incluso desmiente esa falacia dado que como mujer prioriza la razón para conducir su propio destino y es tan capaz como el hombre de defender su honra. Leonor ha desafiado su naturaleza y se ha desplazado de la moralidad correspondiente a su posición de doncella entregándose a don Juan, hecho que la convierte en transgresora de la normativa patriarcal. Ante lo agraviante de la situación, Leonor pone en evidencia al verdadero infractor de las normas y obtiene el reconocimiento de legítima esposa. Cuando finalmente Leonor enfrenta a don Juan, le dice:

(...) fingir pude engaños nuevos,

y ahora, arrojada y valiente,

por mi casto honor volviendo,

salí a quitarte la vida,

y lo hiciera, ¡vive el cielo!

a no verte arrepentido (...) (CARO, 1993, vv. 2715- 2720)

Desde el principio, Leonor es consciente de su condición de mujer agraviada pero nunca se siente culpable de los hechos. El único infractor a las normas jurídicas y divinas es don Juan, el único arrepentido, en consecuencia, el único culpable.

Durante el siglo XVII, el teatro ocupó un lugar central en la vida de los españoles y la escritura de Ana Caro enalteció la comedia áurea de tal modo que es considerada

14. "Parecería que, en el mejor de los casos, el travestismo es un sitio de cierta ambivalencia que refleja la situación más general de estar implicado en los regímenes de poder mediante los cuales se constituye al sujeto y, por ende, de estar implicado en los regímenes mismos a los que uno se opone" (BUTLER, 2002, p. 184). 
la primera dramaturga que cobró por su producción dramática. El reconocimiento proviene no solo por la calidad de su expresión, sino también, por su osadía en el modo de presentar un personaje femenino resuelto a reivindicar su honor.

Una de las "tretas" de la dramaturga es mostrar una pecadora y delincuente, que no siente culpa. El único arrepentido, don Juan, es el verdadero violador de las normas morales y jurídicas. Otra "treta" hábilmente manejada es la utilización del disfraz varonil, que si bien era un recurso frecuente en la comedia de la época, Ana Caro lo aprovecha al máximo. Como señala Lola LUNA, "el disfraz podría interpretarse como una rebelión velada contra las Pragmáticas sobre la moda femenina, las cuales forman parte de una política de control del cuerpo de las mujeres" (1993, p. 27). La protagonista es tan indócil a las normas que se atrevió a disfrutar de su cuerpo y, luego, tuvo el ingenio para travestirlo y urdir una serie de enredos amorosos. Además, Leonor debe exagerar su comportamiento como Leonardo para hacer creíble su representación y, de ese modo, se ponen en evidencia las nefastas conductas masculinas como la cobardía para enfrentar los hechos y el ocultamiento de la verdad.

La escritura teatral de Ana Caro resalta el ingenio femenino y la capacidad de gestionar un proyecto reivindicador de su condición de mujer y se atreve a mostrar al hombre como el verdadero infractor a los códigos del honor.

\section{LAS PRECURSORAS}

Hoy sabemos que muchas mujeres desoyeron las imposiciones patriarcales y se atrevieron a poner por escrito sus ideas. No todas tuvieron la dicha de ser conocidas y estimadas 
por sus contemporáneos como María de Zayas y Ana Caro. En la mayoría de los casos, como el de Marina de Carvajal, pasaron desapercibidas y casi menospreciadas por la opinión hegemónica masculina ${ }^{15}$. Más allá de reconocimiento o no, estas mujeres se animaron a escribir en un medio hostil, que les negaba la posibilidad de hacerlo por considerarlas sujetos incapaces. Todas ellas fueron unas valientes precursoras, sin embargo, debieron ser muy cautelosas con lo que escribían y con el modo en que lo hacían.

Si bien ellas alteraron el orden establecido haciendo pública sus voces, la confrontación con la estructura patriarcal nunca podría haber sido ni total ni frontal por precaución ante la reacción de los inquisidores. Debieron ser meticulosas y utilizar variadas estrategias discursivas como la falsa modestia, pedido de disculpa por su osadía, recurrir a los finales felices y suavizar algunas afirmaciones. Además, las tres escritoras tuvieron la habilidad de incorporarse a las tendencias narrativas, poéticas y teatrales del momento y, de ese modo, lograron ingresar al campo literario dominado por los hombres. Todas "tretas" para decir sin exponerse, para criticar veladamente, para mostrar su posición sin arriesgarse demasiado.

Los personajes femeninos de las tres escritoras se hacen responsables de las determinaciones adoptadas para sus vidas, asumen la situación y actúan en consecuencias. Esta representación se desplaza del sistema de carencias, que pesa sobre ellas, y las posiciona como sujetos con capacidad física, con fortaleza moral e ingenio para disponer. Los personajes zayescos demuestran las injusticias del sistema patriarcal, las

15. Leonor de Meneses (¿?-1664). Catalina Clara Ramírez de Guzmán (16181684?). Leonor de la Cueva y Silva (1611-1705). Feliciana Enríquez de Guzmán (1572-1624). Beatriz Bernal (1501?-1562?) Se sugiere visitar la página de Bibliografía de Escritoras Españolas (BIESES), bieses.net 
mujeres de Mariana Carvajal defienden la autodeterminación para gestionar sus vidas y la protagonista de Ana Caro lucha por restituir su condición de mujer.

Ellas procuraron desmontar esas grandes verdades consagradas en los discursos dominantes, verdades negadoras del intelecto femenino, concluyentes en sus competencias y determinantes de su destino. Cada una con su estilo se corrió del modelo epistemológico / axiológico aportado por los tratados científicos y morales y, de esa manera, contribuyeron a "dessujetar" a las mujeres de una representación interesada sobre lo femenino. Esto implicó discrepar con la performatividad biológica, social y moral patriarcal y tener la osadía de atreverse a ofrecer una imagen de mujer como un sujeto íntegro.

\section{REFERENCIAS}

Amorós, C. La gran diferencia y sus pequeñas consecuencias... para las luchas de las mujeres. Barcelona: editorial Cátedra, 2005. 468 p.

Armon, S. (2014). Compromiso y distanciamiento en La Venus de Ferrara de Mariana de Carvajal y Saavedra. En: Edad de Oro. Revista de Filología Hispánica n ${ }^{\circ} 23$ Madrid: Universidad Autónoma de Madrid, p. 351-363

Azpilcueta, M. de (1586). Compendio del manual de confesores y penitentes. Valladolid, en casa de Diego Fernández de Córdoba, impresor de su Majestad. Disponible en: http://www.biu-toulouse.fr/ tolosana/lemso/ Acceso: 5 de febrero 2021.

Baranda Leturio, N. Cortejo a lo prohibido. Lectoras y escritoras en la España moderna. Madrid: Arco Libros, 2005. 262 p.

Butler, J. Cuerpos que importan. Sobre los límites materiales y discursivos del "sexo". Buenos Aires: Paidós, 2002. 344 p.

El género en disputa: el feminismo y la subversión de la identidad. Barcelona: Paidós, 2007. 311 p.

Cacho, M. Los moldes de Pygmalión. (Sobre los tratados de educación femenina en el Siglo de Oro). En: Zavala, I. (coord.). Breve historia de la literatura española (en lengua castellana). II La mujer en la 
literatura española. Barcelona: Anthropos, 2012, p. 177-215.

Caro Mallén, A. Valor, agravio y mujer. Edición, introducción y notas de Lola Luna. Madrid: Castalia, 1993. 185 p.

Carvajal, M. de. Navidades de Madrid. Madrid: Conserjería de Educación y Cultura, Clásicos madrileños, 1993. 277 p.

Covarrubias Orozco, S. de. Tesoro de la Lengua castellana o española. Edición Felipe Maldonado. Madrid: Castalia, 1995. 1047 p.

Foucault, M. Vigilar y castigar. Nacimiento de la prisión. Buenos Aires: Siglo veintiuno editores, 2012. 318 p.

Historia de la locura en la época clásica. Vol. II, México: Fondo de Cultura Económica, 1967. 243 p.

--an anormales. Buenos Aires: Fondo de Cultura Económica, 2007. 325 p.

Grande Yáñez, M. De Cervantes a Calderón. Claves filosóficas del barroco español. Madrid: Editorial Dykinson, 2012. 209 p.

Huarte de San Juan, J. Examen de ingenios para las ciencias. Edición de Guillermo Ceres. Madrid: Cátedra, 2005. 724 p.

Lagarde y de los Ríos, M. Los cautiverios de las mujeres. Madresposas, monjas, putas, presas y locas. México: UNAM, Colección Posgrado, 2005. $869 \mathrm{p}$.

León, fray L. de. La perfecta casada. Buenos Aires: Bureau Editor, 1999. $92 \mathrm{p}$.

Ludmer, J. Las tretas de débil. En: González, P.; Ortega E. (eds.). La sartén por el mango. Encuentro de escritoras latinoamericanas. Puerto Rico: Ediciones El Huracán, 1985, p. 47-54.

Luna, L. "Estudio preliminar" de Valor, agravio y mujer de Ana Caro Mallén. Madrid: Castalia, 1993. 185 p.

Maravall, J. Antiguos y modernos. Madrid: Alianza editorial, 1986. 628 p.

Teatro y literatura en la sociedad barroca. Madrid: editorial Crítica, 1990. 202 p.

Olivares, J. "Estudio preliminar" en María de Zayas y Sotomayor, Honesto y entretenido sarao. (Primera y segunda parte). Zaragoza: Prensas de la Universidad de Zaragoza. 2 Vol., 2017.

Rodríguez de la Flor, F. Mundo simbólico. Poética, política y teúrgia en el Barroco. Madrid: Akal, 2012. 294 p. 
Vigil, M. La vida de las mujeres en los siglos XVI y XVII. Madrid: Siglo veintiuno, 1986. $261 \mathrm{p}$.

Villalba Pérez, E. ¿Pecadoras o delincuentes? Delito y género en la corte (1580-1630). Madrid: Calambur, 2004. 332 p.

Vives, J. Instrucción de la mujer cristina. Buenos Aires: Espasa-Calpe, 1940. $191 \mathrm{p}$.

Wittig, M. El pensamiento heterosexual y otros ensayos. Madrid: Egales, 2006. 127p.

Zayas y Sotomayor, M. de. Honesto y entretenido sarao. (Primera y segunda parte). Zaragoza: Prensas de la Universidad de Zaragoza. 2 Vol., 2017. 


\section{CAPÍTULO 3}

\section{A IMAGEM DE JANE AUSTEN EM BIOGRAFIAS DO SÉCULO XIX}

Daiane da Silva Lourenço (UTFPR)

A escritora inglesa Jane Austen (1775-1817) viveu em um contexto marcado por padrões de gênero rigorosos. As mulheres inglesas eram privadas de direitos civis e políticos, com restrições ao acesso à educação formal e ao trabalho remunerado, ao direito à propriedade e ao voto. Neste contexto, espaços distintos eram estabelecidos para os gêneros: o espaço público majoritariamente ocupado por homens, e o espaço doméstico reservado às mulheres. A naturalização de um ideal de feminilidade no período convencionou comportamentos julgados como inadequados para as mulheres. Como a modéstia era uma virtude feminina cultivada, o que implicava não expressar opiniões em público, a escrita literária era vista como uma atividade essencialmente masculina. Aquelas que ousavam publicar textos eram definidas como não femininas, anormais, desviantes dos padrões.

Apesar de tais restrições, Jane Austen publicou seis romances entre 1811 e 1818, nos quais aborda o universo doméstico da perspectiva feminina e questiona a educação destinada as mulheres. Como por muito tempo as representações de mulheres foram produzidas na literatura 
pelo olhar masculino, é considerada uma das escritoras precursoras no século XIX. Ao lado de outras escritoras (Charlotte Brontë, Emily Brontë, George Eliot), teve que lidar com a opressão e quebrar com concepções de feminilidade impostas, sendo por isso vista como louca por tentar ocupar um espaço masculino (GILBERT; GUBAR, 2000). O gênero era o principal obstáculo enfrentado por mulheres que queriam registrar e publicar suas perspectivas.

Após a morte de Jane Austen, uma imagem da escritora começou a ser construída a partir de biografias publicadas por familiares. Diante disso, analisamos as biografias de Henry Austen, Biographical Notice of the Author (1818), e James Edward Austen-Leigh, A Memoir of Jane Austen (1871) a partir da perspectiva da crítica feminista, que evidencia os sentidos construídos sobre ser mulher naquele contexto, e dos estudos culturais, que suscita questionamentos sobre conceitos consolidados na época, como o que era visto como ideal de feminilidade, e lança luz sobre o poder da representação.

Por meio de um estudo interpretativo, olhamos para as imagens de Jane Austen propagadas nas biografias do século XIX, as quais focam mais no papel social de mulher que era performado do que na escritora de literatura. Para tanto, abordamos concepções de feminilidade presentes na Inglaterra do período. Em seguida, analisamos a construção da representação de Jane Austen nos textos. As biografias mostram uma mulher doce, modesta, dedicada ao lar, que atende a padrões de feminilidade e que escreve como passatempo. No entanto, a publicação em décadas posteriores de cartas da escritora e de textos escritos na adolescência revela um lado mais afiado e irônico, omitido nas biografias, e uma escritora minuciosa que revisava cuidadosamente os textos. 


\section{CONCEPÇÕES DE FEMINILIDADE NA INGLATERRA DO SÉCULO XIX}

As concepções de feminilidade surgem de processos históricos, sociais e culturais que constroem e naturalizam ideias sobre papéis sociais de gênero. Portanto, os padrões de gênero propagados na sociedade não são naturais, mas uma constituição simbólica que resulta de processos de opressão e de hierarquização de diferenças entre masculino e feminino (CAMPOS, 1992). Neste sentido, a visão do que é ser feminina costuma estar associada a comportamentos esperados das mulheres em determinado contexto, os quais, no ocidente, incluem: ser frágil, dócil, sensível, altruísta, cuidar da beleza, entre outros. Partindo dessa perspectiva, abordamos expectativas sociais para mulheres na Inglaterra oitocentista.

No início do século XIX, na Inglaterra, havia um ideal estabelecido para as mulheres para que fossem consideradas proper ladies, aquelas vistas como virtuosas e respeitáveis. $\mathrm{O}$ comportamento de proper lady era esperado principalmente das jovens que pertenciam a classes sociais altas, na época denominadas gentry e aristocracia. Essa visão estava tão naturalizada na sociedade britânica que as mulheres eram preparadas desde crianças para desenvolverem as habilidades consideradas fundamentais para ser esposa e mãe, tendo sua educação voltada para o espaço doméstico.

A educação formal de todos os níveis sociais da Inglaterra contribuía com a manutenção dos papéis de gênero. De acordo com Teachman (1997), a educação formal das filhas era considerada de menor importância do que a dos filhos. Os homens eram educados em escolas e geralmente frequentavam a universidade para seguirem uma carreira. Já as mulheres de classe alta eram educadas em casa, pela mãe, governanta ou tutora, para serem esposas e 
donas de casa. Apesar de aprenderem a ler e a fazer cálculos básicos para gerenciar a organização doméstica, a maior parte da formação das meninas era dedicada a aprender a tocar piano, cantar, dançar, bordar, desenhar e pintar. As mulheres de classe baixa aprendiam o básico sobre tarefas domésticas, incluindo costurar e cozinhar, para terem a possibilidade de se casar com homens com pequeno patrimônio ou de trabalhar como criadas.

Essa visão distinta de educação baseada no gênero predominava em um momento histórico no qual as mulheres inglesas eram privadas de direitos civis e políticos, pois havia restrições ao acesso à educação formal e ao trabalho remunerado, ao direito à propriedade e ao voto. Neste contexto, o casamento era a principal forma de uma mulher assegurar estabilidade financeira e posição social. A preparação desde crianças para desenvolver habilidades específicas era uma forma de as famílias de classe alta proporcionarem um casamento rentável para as filhas já que, de acordo com as leis, a mulher era propriedade do homem: primeiro do pai, depois do marido. Mary Wollstonecraft, na obra Reivindicação dos direitos da mulher (1792), denuncia como a negação do acesso à educação formal para as mulheres e sua reclusão à vida doméstica fazia com que fossem dependentes dos homens (pai, irmão, marido). No final do século XVIII, Wollstonecraft já defendia o direito à educação formal como uma maneira de mudar a visão do papel social da mulher. Mas somente na década de 1860 as inglesas conquistaram o direito de frequentar o ensino superior. Por muito tempo as mulheres estiveram submetidas a restrições econômicas, sociais e morais.

Neste período, espaços distintos eram estabelecidos para os gêneros: homens ocupavam o espaço público, 
trabalhando ou socializando em reuniões, festas, clubes, enquanto a esfera privada era reservada às mulheres, com a casa e a família sob sua responsabilidade. Além de aprender sobre o espaço doméstico, as mulheres eram educadas para terem comportamentos julgados como adequados às convenções sociais e morais britânicas. De acordo com Poovey (1984), diante da necessidade que a sociedade sentia de cultivar as virtudes femininas, um conjunto de obras literárias emergiram, no século XVIII, dedicadas exclusivamente a apresentar instruções sobre condutas apropriadas para mulheres: conduct books. Os livros de conduta tinham como objetivo ensinar às jovens como deveriam agir no espaço privado e no público para serem vistas como virtuosas, focando em comportamentos "naturalmente femininos".

Tais obras adquiriram popularidade devido ao aumento de leitoras da classe média e propagam uma perspectiva de feminilidade centrada na ideologia cultural do período (POOVEY, 1984). O discurso moral presente nos livros de conduta é criticado por Wollstonecraft (2016) por difundir a ideia de que características como ser modesta, gentil, dócil, frágil, sensível e emotiva são naturalmente femininas. Para a autora, esses textos criam uma imagem idealizada de feminilidade que é colocada como regra para todas as mulheres:

Os moralistas permitem aos homens cultivar, como manda a Natureza, diferentes qualidades e assumir os diversos aspectos que as mesmas paixões, modificadas quase ao infinito, dão a cada indivíduo. Um homem virtuoso pode ter uma constituição colérica ou otimista, ser alegre ou sério, sem ser reprovado; ser firme o mais que puder ou tão dócil que não tenha vontade ou opinião própria; mas todas as mulheres têm de ajustar-se, por meio da mansidão e da 
docilidade, a um mesmo caráter de doçura condescendente e de amável submissão (WOLLSTONECRAFT, 2016, p. 126-127).

Diante da submissão esperada, as mulheres eram instruídas a não expressar suas opiniões em público, pois aquela que revelava seus desejos de forma assertiva era considerada perigosa (POOVEY, 1984). Falar abertamente em público era uma característica masculina, portanto as jovens deveriam ter um comportamento oposto. Além disso, Poovey (1984) ressalta que os livros de conduta também indicam atividades que as mulheres deveriam evitar, como frequentar o teatro ou masquerades, flertar ou vestir-se de modo provocativo, e ler romances, pois a mente feminina poderia ser corrompida. Esse ideal de feminilidade disseminado promoveu uma representação de mulher denominada "anjo do lar" por Woolf (2012).

A partir de um poema de Coventry Patmore, The Angel in the House, Woolf (2012) aborda o esforço das mulheres do século XIX para se adequarem aos padrões e as compara com a figura feminina do poema. Segundo Woolf (2012), a "mulher Anjo do Lar" deveria ser simpática, totalmente altruísta, excelente na arte do convívio familiar, ser pura, se sacrificar todos os dias e nunca ter opinião ou vontade própria. A autora afirma que toda casa neste momento histórico tinha seu "Anjo", uma mulher vivendo sob as convenções sociais de modéstia e negação da razão. Diante disso, qualquer atitude de exposição de opinião e conhecimento por parte de uma mulher era criticada, pois o exercício da mente era visto como uma atividade essencialmente masculina. A mulher desviante das condutas esperadas era considerada não feminina, um "monstro". Neste contexto sócio-histórico-cultural viveu Jane Austen, uma mulher que publicou seis romances, não se casou e não teve filhos. 
Jane Austen nasceu em 1775, em Steventon, Hampshire, ao sul da Inglaterra. Filha do reverendo George Austen e de Cassandra Leigh Austen, foi criada em um ambiente intelectual visto que o pai era responsável pela paróquia de Steventon, tinha vários livros que deixava à disposição da família e mantinha um internato para garotos. Apesar da difícil situação financeira da família, pois George Austen retirava o sustento das aulas e venda de produtos de uma fazenda que administrava (REEF, 2014), os filhos tiveram acesso à ampla biblioteca da paróquia com livros sobre história, poesia, grandes ensaístas do século e muita ficção (HARMAN, 2009).

Diante da diferença de educação formal destinada a meninos e a meninas, o contexto familiar de Jane Austen parece ter lhe possibilitado o acesso a uma educação de qualidade, mesmo tendo frequentado a escola por pouco tempo. Segundo Irvine (2005), Jane e Cassandra foram educadas pela mãe em leitura, escrita e religião. Depois, estudaram por dois anos em internatos, primeiro em Oxford e Southampton em 1783 e depois de 1785 a 1786 na cidade de Reading.

Harman (2009) relata que na virada do século XVIII para o XIX, Austen tinha vinte e cinco anos, não estava casada, não tinha filhos, não havia conseguido publicar nenhum livro e não sabia ao certo se teria um futuro como escritora. De acordo com as expectativas sociais da época, nessa idade uma mulher já deveria estar casada, cuidando dos afazeres domésticos e com a renda anual assegurada pelo marido. Assim como Jane Austen, sua irmã Cassandra também não se casou. Com a morte do pai em 1805, a escritora, sua mãe e a irmã Cassandra não tinham recursos para se sustentar porque era comum que uma propriedade fosse transferida de um membro da família para outro em uma linha de sucessão 
masculina. O filho mais velho geralmente herdava os bens da família. O costume obrigava as filhas a se casarem como forma de ter uma renda financeira garantida pelo marido (REEF, 2014), no entanto as duas filhas da família não estavam casadas.

Em 1809, Jane Austen mudou-se para Chawton devido a uma oferta do irmão Edward para que morasse em uma casa em sua propriedade com a mãe e a irmã. Após a venda dos primeiros romances, Jane Austen conseguiu ter uma renda própria. As obras Razão e Sensibilidade (1811), Orgulbo e Preconceito (1813), Mansfield Park (1814) e Emma (1815) foram publicadas anonimamente. No dia 18 de julho de 1817, aos 41 anos, a escritora faleceu em Winchester. Os romances Persuasão e Northanger Abbey foram publicados em dezembro de 1817 em uma edição conjunta após sua morte. Henry Austen escreveu uma pequena biografia para tal edição na qual apresenta sua irmã Jane Austen aos leitores como a verdadeira autora das obras publicadas anonimamente. Para Auerbach (2004), esse foi o início de uma onda de biografias que divulgam a imagem de Jane Austen como uma mulher doce e modesta. Essa representação da escritora em biografias do século XIX repercute ainda hoje, por isso as biografias são analisadas neste estudo como textos com o poder de produzir e propagar representações sobre ser mulher.

\section{REPRESENTAÇÕES DE JANE AUSTEN}

Há poucos registros sobre a vida de Jane Austen. A escritora não mantinha um diário, muitos dos manuscritos originais de suas obras foram perdidos e das cerca de três mil cartas que escreveu, apenas cento e sessenta sobreviveram para serem divulgadas. Logo após a sua morte, familiares 
registraram relatos e publicaram informações sobre sua vida para que leitores de suas obras conhecessem mais sobre a escritora. Henry Austen, irmão de Jane Austen, publicou Biographical Notice of the Author na primeira edição de Northanger Abbey e Persuasion, produzida no final de dezembro de 1817, mas datada como 1818. Segundo Gilson (1997), foi a primeira tentativa de apresentar detalhes sobre a vida de Jane Austen, por isso tem uma importância única como documento. Esse texto de Henry Austen foi republicado em 1833, com omissões, alterações e adições, sob o título Memoir of Miss Austen, na edição de Sense and Sensibility organizada por Richard Bentley (GILSON, 1997). Somente em 1870 uma nova biografia de Jane Austen seria divulgada pelo sobrinho James Edward Austen-Leigh, A Memoir of Jane Austen. Essas biografias ${ }^{1}$ apresentam aos leitores representações de mulheres construídas em um momento histórico, dentro de práticas discursivas específicas, empregando estratégias e iniciativas singulares para construir imagens que a família queria (HALL, 2014).

As representações de mulheres por muito tempo foram produzidas apenas pelo olhar masculino porque a caneta estava restrita às mãos de homens. Gilbert e Gubar (2000) explicam que no início do século XIX a caneta ainda era vista como uma ferramenta masculina. $\mathrm{O}$ ato de escrever e publicar era inapropriado para uma mulher, por isso poucas ousavam registrar suas opiniões e, quando o faziam, muitas vezes preferiam omitir seu nome usando pseudônimos masculinos. Neste contexto, as primeiras biografias registradas de Jane Austen têm autoria masculina. A partir da crítica feminista

1. As biografias foram reunidas no livro A memoir of Jane Austen: and other family recollections, editado por Kathryn Sutherland, em 2002. As referências no texto seguem a paginação dessa obra. 
e dos estudos culturais, estudamos as percepções sobre mulheres e a representação de Jane Austen nesses textos.

Segundo Zolin (2009), analisar uma obra a partir da crítica feminista implica investigar como o texto está marcado pela diferença de gênero e por relações de poder entre homem e mulher na sociedade. No início de Biographical Notice of the Author (1818), Henry Austen afirma que sua tarefa de falar sobre a vida da irmã será fácil, visto que não teve uma vida de grandes eventos. A assertiva de Henry Austen desconsidera o fato de que Jane Austen escreveu seis romances, pois de uma perspectiva patriarcal do período histórico a vida de uma mulher era considerada significativa caso tivesse cumprido com o seu papel social de gênero convencionado, isto é, se casar e ter filhos. Além disso, desqualifica o espaço doméstico reservado às mulheres comparado ao espaço público ocupado majoritariamente por homens.

$\mathrm{Na}$ biografia, Jane Austen é apresentada como uma pessoa alegre, sensível, benévola, modesta e incapaz de ofender outra pessoa. Os trechos a seguir explicitam características reforçadas socialmente como femininas: "suas bochechas ficavam rosadas", "sua voz era extremamente doce", "ela desenhava muito bem", "não dava muito crédito às suas qualidades musicais", "gostava de dançar e era muito boa nisso", "sempre procurou nas falhas dos outros algo para desculpar, perdoar ou esquecer", "nunca proferiu uma expressão apressada, tola ou severa", "seu temperamento era polido". O foco na personalidade doce, despretensiosa e virtuosa de Jane Austen, em vez de narrar para o público sua dedicação à escrita literária, mostra a preocupação da família com uma representação de mulher que estivesse dentro do ideal de feminilidade do século XIX. 
Jane Austen é caracterizada como uma pessoa sem a mínima intenção de publicar seus romances, pois "foi com extrema dificuldade que seus amigos, cuja parcialidade ela suspeitava embora respeitasse seu julgamento, a convenceram a publicar seu primeiro trabalho” (p. 140, tradução nossa ${ }^{2}$ ). Jamais intencionou fama ou lucro, escrevia por prazer. Diante disso, não acreditou quando lucrou cento e cinquenta libras com Razão e Sentimento, "considerou a quantia uma enorme recompensa por aquilo que não lhe custou nada" (p. 140, tradução nossa ${ }^{3}$ ). Ao longo de toda a biografia, a escrita é considerada uma atividade para passar o tempo e entreter sua família, sem qualquer outro objetivo e sem ser priorizada, pois a dedicação ao lar e à família estavam sempre em primeiro lugar. Apenas no penúltimo parágrafo a qualidade da escrita de Jane Austen é abordada ao dizer que suas cartas possuem o estilo de seus romances: bem escritas, com ideias claras e expressões perfeitamente escolhidas, dignas de publicação.

Jane Austen lia muito e estava sempre familiarizada com os méritos e defeitos dos melhores textos em língua inglesa, no entanto utilizava o discernimento para a partir das leituras escrever seus textos. Por isso, tinha predileção por escritores moralistas como Johnson, na prosa, e Cowper, em verso, e evitava autores de baixa moral, como Fielding. A afirmação que Jane Austen preferia textos moralmente adequados para as mulheres está de acordo com os ensinamentos dos livros de condutas, que orientavam quais textos podiam ser lidos pelas jovens. Os romances eram considerados perigosos. Wollstonecraft (2016, p. 93) avalia a relação das mulheres com

2. No original: "It was with extreme difficulty that her friends, whose partiality she suspected whilst she honoured their judgement, could prevail on her to publish her first work" (Biographical Notice of the Author, 2002, p. 140).

3. No original: "She regarded the above sum as a prodigious recompense for that which had cost her nothing" (Biographical Notice of the Author, 2002, p. 140). 
a educação pela leitura no trecho: "tirem-nas de sua família ou vizinhança, e elas ficam inativas; não têm onde ocupar sua mente, já que a literatura proporciona uma fonte de diversão que elas nunca buscaram desfrutar e que desprezam com frequência”. A autora critica a negação da razão para as mulheres, o que faz com que não cultivem a mente e sejam dependentes dos homens. Essa não parece ser a situação de Jane Austen, apesar da forma como seu interesse pela leitura é descrito na biografia. As personagens femininas criadas pela escritora são leitoras vorazes de romances e demonstram conhecimento de literatura que a própria Jane Austen adquiriu ao longo da vida.

No final da biografia há um Postscript no qual Henry Austen afirma que inclui trechos de correspondências pessoais da escritora na publicação para que o público confirme, ao lêlos, o temperamento e os sentimentos de Jane Austen. Como os trechos podem facilmente ser manipulados, Auerbach (2004) evidencia a intenção de whitewashing, uma tentativa de impedir as pessoas de conhecerem a verdade e de encobrir fatos considerados desagradáveis. Apenas quatro partes curtas de cartas são reproduzidas, as quais reiteram a doçura e a gentileza da escritora. No entanto, a leitura de cartas na íntegra, posteriormente publicadas em coletâneas, mostra um lado irônico e perspicaz de Jane Austen.

A biografia cria uma primeira representação da mulher Jane Austen, enfatizando como atende às convenções sociais de gênero da época e desvalorizando seu trabalho de escrita literária. De acordo com Silva (2014), a representação é uma forma de atribuição de sentido dentro de uma cultura. A forma como determinada identidade é vista pela maioria das pessoas em um contexto social depende de como foi representada por quem tem o poder de representar. A repetição 
de proposições acerca de um grupo pode contribuir com o processo de produção de sua representação. Neste sentido, uma concepção de feminilidade foi elaborada e propagada no início do século XIX, na Inglaterra, a qual foi estabelecida como padrão para as mulheres. Biographical Notice of the Author busca registrar que Jane Austen atendia completamente aos padrões sociais afirmando que ser escritora não era seu propósito de vida. Pois, mesmo com a qualidade de sua escrita, o gênero era o principal obstáculo enfrentado pelas escritoras, as quais por serem mulheres eram julgadas como inadequadas (GILBERT; GUBAR, 2000). Essas representações de mulheres como anjos ou monstros, a partir de estereótipos rígidos de feminilidade, só começou a mudar com o aumento das publicações de narrativas de escritoras, com personagens femininas que desestabilizam as imagens de mulheres na literatura, até então predominantemente de autoria masculina.

As obras de Jane Austen foram vendidas enquanto estava viva e nos anos seguintes à sua morte (HARMAN, 2009). A partir da década de 1820, seguiu-se um período de esquecimento da escritora e de suas obras. A família não sentiu a necessidade de publicar uma biografia até a década de 1860, quando comentários desagradáveis a respeito de Jane Austen começaram a surgir. Em 1869, decidiram que uma memoir seria escrita por James Edward Austen-Leigh, reunindo memórias dos sobrinhos, para resolver as questões entre o público e Jane Austen.

A Memoir of Jane Austen foi publicado em 1870, primeira edição, e uma segunda edição em 1871. James Edward AustenLeigh chama a escritora de "querida tia Jane". A construção da representação da "tia Jane" inicia com a afirmação de que viveu uma vida sem grandes acontecimentos. Nas duas 
biografias, a história de vida de Jane Austen é descrita dessa forma por causa da inexistência de um casamento e de filhos. Diante disso, Auerbach (2004) questiona porque o estado civil de Samuel Taylor Coleridge, Charles Dickens e Herman Melville não é objeto de discussão. O de Jane Austen, ao contrário, foi enfatizado em enciclopédias ao longo do século XX (AUERBACH, 2004). Woolf (2014) também discute como as atividades essencialmente desenvolvidas por mulheres são consideradas inferiores às dos homens: futebol e esportes são considerados importantes, já falar sobre moda e comprar roupas, trivial. Esses valores são transferidos da vida para a ficção de maneira que a crítica julga um livro importante porque trata da guerra e outro insignificante porque trata dos sentimentos das mulheres (WOOLF, 2014).

As identidades e representações são construídas a partir da diferença (WOODWARD, 2014). Os relatos anteriores demonstram uma marcação rigorosa de diferença entre homens e mulheres. Para Woodward (2014), essa oposição binária implica em um desequilíbrio de poder que faz com que uma parte seja sempre mais valorizada do que a outra. Naquele contexto histórico, a desvalorização dos espaços predominantemente ocupados por mulheres estava culturalmente instituída.

James Edward Austen-Leigh procura reiterar as características femininas de Jane Austen apresentadas na primeira biografia e inserir novos relatos para comprová-las, focando em uma representação de mulher que atende aos estereótipos de feminilidade, apesar de não ter se casado e de ter publicado textos literários. Diante disso, A Memoir of Jane Austen aborda relatos sobre como a jovem Jane Austen foi objeto de afeição. Recusou um pedido de casamento de um homem de bom caráter e de uma boa posição social que 
não tinha tocado seu coração quando era jovem. Cassandra revelou à família, após a morte da irmã, que em uma viagem a algum lugar na costa, conheceram um cavalheiro charmoso, inteligente e de boas maneiras que parece ter tido interesse por Jane Austen e ela por ele. O cavalheiro expressou a intenção de voltar a ver as irmãs, mas nunca mais se encontraram. Um tempo depois ouviram que ele havia falecido. Além desses, há um terceiro relato, breve, a respeito de uma aproximação entre Jane Austen e Thomas Lefroy, membro de uma família vizinha.

Trechos e cartas completas são reproduzidas, mas o biógrafo alerta aos leitores que não são interessantes porque abordam apenas detalhes da vida doméstica, sem registros sobre política, eventos públicos, discussões sobre literatura, ou outros assuntos de interesse geral. A partir de tais comentários, percebe-se o espaço doméstico sendo considerado inferior ao universo masculino, no qual os assuntos considerados de "interesse geral" são discutidos. Além disso, Auerbach (2004), após analisar as cartas publicadas na biografia, explica que, apesar de parecer que estão completas, Austen-Leigh as selecionou e omitiu comentários afiados, referências políticas e literárias, e vocabulário da medicina. O lado intelectual da escritora é omitido.

Austen-Leigh afirma que Jane Austen começou a escrever na adolescência, porém considera os textos produzidos nesta fase como irrelevantes, narrativas tolas e bem-humoradas produzidas para a diversão da família. Para o biógrafo, a família sabiamente decidiu não publicar as narrativas. Os textos foram reunidos e publicados sob o título de Juvenilia décadas depois. A preocupação da família não era com a qualidade da escrita de Jane Austen nessas produções consideradas imaturas, mas com as ideias explícitas que 
aparecem de modo velado nos romances. As personagens femininas de Juvenilia lutam, bebem, mentem. Um lado da escritora que os familiares não queriam que fosse conhecido, por contradizer a imagem que as biografias apresentam.

De acordo com a biografia, Jane Austen não tinha interesse pelo sucesso ou por dinheiro. Sua vida foi dedicada aos afazeres domésticos e ao cultivo do afeto familiar, sem esperar qualquer aplauso ou elogio. Apesar da ênfase na tia doce e virtuosa, em detrimento da escritora, ao longo do texto a dedicação de Jane Austen à escrita é mencionada ainda que descrita como passatempo. Jane Austen escrevia em folhas de papel pequenas que podiam facilmente ser escondidas ou cobertas. $\mathrm{Na}$ casa havia uma porta que rangia ao ser aberta, a qual ela nunca permitiu que fosse consertada porque permitia saber quando alguém estava vindo. Ao contrário da biografia de 1818, particularidades sobre a escritora e suas obras são discutidas.

No primeiro ano morando em Chawton, Jane Austen revisou Razão e Sensibilidade e Orgulbo e Preconceito para publicação. Além disso, entre 1811 e 1816, Jane Austen começou e concluiu Mansfield Park, Emma e Persuasão. Considerando suas condições para escrever, "é surpreendente como ela foi capaz de fazer tudo isso, pois não tinha um escritório separado para se recolher, e a maior parte do trabalho deve ter sido feita na sala de estar geral, sujeita a todos os tipos de interrupções casuais" (p. 81, tradução nossa $)^{4}$. A biografia apresenta trechos de cartas que revelam o interesse de Jane Austen na recepção de seus textos e o carinho por suas obras.

4. No original: "How she was able to effect all this is surprising, for she had no separate study to retire to, and most of the work must have been done in the general sitting-room, subject to all kinds of casual interruptions" (A Memoir of Jane Austen, 2002, p. 81). 
Em 29 de janeiro de 1813, logo após a publicação de Orgulho e Preconceito, escreve para Cassandra: "Eu quero contar que recebi meu próprio filho querido que chegou de Londres", e acrescenta "Devo confessar que acho que ela [Elizabeth] é a criatura mais encantadora que já foi publicada, e como eu poderei tolerar aqueles que não gostam pelo menos dela eu não sei” (p. 82-83, tradução nossa) ${ }^{5}$. Na mesma carta revela que verificou a versão impressa já em circulação para ver se alguma melhoria poderia ser feita: "Há alguns erros de impressão; e um 'disse ele', ou um 'disse ela', poderia deixar o diálogo mais imediatamente claro” (p. 83, tradução nossa) ${ }^{6}$. Outras cartas revelam que Jane Austen faz críticas ao próprio trabalho, como quando afirma, em uma carta enviada à Cassandra em 4 de fevereiro de 1813, que Orgulho e Preconceito é uma obra muito leve e alegre, poderia ter um pouco de sombra, ou um capítulo longo sobre algo desconectado do enredo, ou um ensaio sobre escrita, ou uma crítica a Walter Scott, entre outras reflexões sobre a versão final.

Além disso, as cartas mostram que a escritora gostava de saber a opinião dos familiares e amigos sobre suas obras. Em uma carta datada de 9 de fevereiro de 1813, pede a Cassandra que dê sua opinião sobre a obra assim que terminar de lê-la e agradece a aprovação da sobrinha Fanny. Para Jane Austen, "ela [Fanny] gostar de Darcy e Elizabeth é o bastante. Ela pode odiar todos os outros, se quiser" (p. 84, tradução nossa) ${ }^{7}$. A escritora mantinha um registro de

5. No original: "I want to tell you that I have got my own darling child from London"; "I must confess that I think her [Elizabeth] as delightful a creature as ever appeared in print, and how I shall be able to tolerate those who do not like her at least I do not know" (A Memoir of Jane Austen, 2002, p. 82-83).

6. No original: "There are a few typical errors; and a 'said he', or a 'said she', would sometimes make the dialogue more immediately clear" (A Memoir of Jane Austen, 2002, p. 83).

7. No original: "Her liking Darcy and Elizabeth is enough. She might hate all the 
críticas, que sobreviveu ao tempo, de pessoas próximas e conhecidas, tanto mostrando expressões positivas sobre suas obras quanto negativas, e também copiava críticas que eram publicadas a respeito de suas obras. Para Harman (2009), é uma marca do orgulho da escritora por seu trabalho.

A biografia indica que no início de 1816 Jane Austen começa a apresentar sinais da doença que a levaria à morte em julho de 1817. Neste último ano de vida, sua atividade de escrita não foi interrompida. O romance Persuasão havia sido concluído em julho de 1816, mas a escritora não ficou satisfeita, queria aprimorar o texto. Apesar da fraqueza causada pelo estado de saúde, cancelou o último capítulo e escreveu dois outros no lugar, totalmente diferentes, concluindo a obra em agosto daquele ano. Austen-Leigh ressalta que os capítulos dez e onze de Persuasão contêm as últimas produções de Jane Austen, não são apenas o final do romance. Sutherland (2002) ressalta como os manuscritos da escritora mostram um longo processo de aprendizado, de reescrita e de cancelamento de trechos, o que contradiz as afirmações de que escrevia como passatempo. Os manuscritos comprovam que os textos finais são resultado de cuidadoso trabalho de revisão, não de perfeição inconsciente (SUTHERLAND, 2002).

As publicações de Biographical Notice of the Author (1818) e A Memoir of Jane Austen (1871) influenciam até hoje a representação da escritora Jane Austen porque são a base de informações para diversas biografias escritas depois. Para Looser (2017), Jane Austen ficou conhecida como "tia Jane" no século XIX devido à forma como sua imagem foi construída após sua morte por uma parte de sua família. As biografias buscaram afirmar Jane Austen como uma mulher feminina, de acordo com as concepções de feminilidade do

others, if she would" (A Memoir of Jane Austen, 2002, p. 84). 
período. Uma forma de evitar o julgamento da escritora como uma mulher anormal, não feminina, monstro.

Woodward (2014) explica que devido às expectativas sociais, identidades diferentes podem ser consideradas "estranhas" ou "desviantes" ou "erradas". Isso acontece porque "todo contexto ou campo cultural tem seus controles e suas expectativas, bem como seu 'imaginário' (...)" (WOODWARD, 2014, p. 33). No século XIX, uma mulher escritora era alvo desse tipo de julgamento, o qual a família tentou evitar. Pode ser que Austen-Leigh tenha tido boas intenções, mas construiu uma representação da tia como feminina, angelical, incapaz de falar mal das pessoas, que nunca pensava em ganhar dinheiro e muito modesta para aceitar elogios (AUERBACH, 2004). Harman (2009) acredita que o objetivo do sobrinho não era colocar a tia como um ideal feminino, mas foi um caminho naturalmente seguido porque além de ser o sobrinho da escritora também era um clérigo.

A partir de 1884, com a publicação de uma edição intitulada Letters of Jane Austen, por Lord Brabourne, uma nova faceta da escritora começa a ser conhecida. O público tem acesso a mais cartas com o passar dos anos, assim como aos seus escritos da adolescência. Até então a "tia Jane" havia sido apresentada ao público como uma pessoa doce e incapaz de falar mal de outros, porém as cartas e os textos escritos na adolescência revelam um lado irônico, afiado e crítico.

Jane Austen escreveu contos, cenas dramáticas, romances curtos, entre 1787 e 1793 (REEF, 2014). Essas narrativas foram copiadas pela escritora em três cadernos, os quais foram nomeados "Volume the first", "Volume the second" e "Volume the third", como se fossem realmente uma publicação em livros. Hoje essas produções são conhecidas como Juvenília 
e revelam um lado irônico de Jane Austen, com críticas aos romances sentimentais produzidos na época, ao padrão de heroínas frágeis e a aspectos da sociedade. As narrativas apresentam algumas personagens femininas que destoam das convenções sociais da época, pois roubam, matam, bebem muito, são viciadas em jogos. No trecho seguinte, a personagem Alice, da narrativa Jack e Alice, é caracterizada como uma mulher viciada em bebidas alcoólicas:

Quando conhecer melhor minha querida Alice, você não ficará surpresa, Lucy, ao ver a criatura beber um pouco demais; pois isso acontece todos os dias. Ela tem muitas qualidades raras e encantadoras, mas a sobriedade não é uma delas. A família toda é um triste bando de bêbados. Também lamento dizer que nunca vi três pessoas mais viciadas em jogo do que eles, em particular Alice (AUSTEN, 2014, posição 1060).

A construção da personagem destoa das convenções sociais de gênero da época, o que pode ter sido o motivo para que essas narrativas não tenham sido divulgadas logo após a morte da escritora. Os textos evidenciam o desenvolvimento da escrita de Jane Austen das suas primeiras produções até a elaboração de seu primeiro romance publicado.

As cerca de cento e sessenta cartas preservadas demonstram como Jane Austen tratava suas obras como filhos, sentia orgulho do resultado de seu trabalho e esperava que outras pessoas reconhecessem seu talento. A venda de todas as cópias de Razão e Sensibilidade é celebrada em uma carta em três de julho de 1813. Jane Austen afirma que lucrou £140 mais os direitos autorais e ressalta que isso só a faz querer mais, por isso já está trabalhando em uma próxima obra. Essas correspondências provam que, ao contrário das 
afirmações de Henry Austen e Austen-Leigh, a escritora não escrevia simplesmente para passar o tempo e entreter a família, havia um trabalho árduo e cuidadoso de elaboração e revisão das narrativas com a intenção de publicá-las.

As cartas também demonstram que Jane Austen não era a tia querida que jamais era indelicada e nunca falava mal de qualquer pessoa. A escritora registrou críticas, brincadeiras, deboches e reclamações. Era comum fazer comentários sobre pessoas presentes nos bailes que frequentava, por exemplo, no entanto nem sempre eram positivos, como o trecho a seguir revela: "Miss Blachford é tolerável; eu não quero que as pessoas sejam muito agradáveis, pois me poupa o trabalho de gostar muito delas" (LE FAYE, 2011, p. 30, tradução nossa). Jane Austen também comenta constantemente sobre a aparência das pessoas. Em uma carta do dia 24 de dezembro de 1800 afirma: "O marido é muito feio; mais feio que o primo John; mas ele não parece ser muito velho"' (LE FAYE, 2011, p. 63, tradução nossa). As descrições incluem críticas ao hálito de conhecidos: "Miss Debary, Susan e Sally vestidas de preto (...) fizeram sua entrada, e eu fui tão educada quanto seu mau hálito me permitiu" "LE FAYE, 2011, p. 63, tradução nossa). Esse último comentário, de acordo com Auerbach (2004), foi omitido da carta quando publicada pela primeira vez na coletânea organizada por Lord Brabourne, em 1884. Lord Brabourne preferiu alterar o trecho para "eu fui tão educada quanto as circunstâncias me permitiram”. A publicação do

8. No original: "Miss Blachford is agreeable enough; I do not want People to be very agreeable, as it saves me the trouble of liking them a great deal" (Carta de 24 de dezembro de 1798).

9. No original: "Her husband is ugly enough; uglier even than his cousin John; but he does not look so very old".

10. No original: "Miss Debary, Susan \& Sally all in black (...) made their appearance, \& I was as civil to them as their bad breath would allow me" (Carta de 20 de novembro de 1800 ). 
original provavelmente faria com que os leitores do século XIX duvidassem do caráter doce de Jane Austen.

\section{CONSIDERAÇÕES FINAIS}

Os relatos de familiares sobre a escritora e as perspectivas de estudiosos citadas mostram que a imagem de Jane Austen foi construída e interpretada de maneiras diferentes desde 1817. A família procurou representá-la como uma mulher virtuosa, doce, modesta, dedicada ao lar, atendendo aos padrões de feminilidade da época. No entanto, suas cartas, mantidas em segredo por muito tempo, revelam uma mulher irônica, afiada, com interesse em ter sucesso na carreira como escritora e em vender suas obras.

As palavras da personagem Anne Elliot, de Persuasão, ao afirmar que a pena sempre esteve nas mãos dos homens e esses representavam as mulheres da forma como queriam, são aqui lembradas para ressaltar a verdade de tal afirmação. A representação de Jane Austen foi fortemente influenciada pelo que homens escreveram em suas primeiras biografias. Henry Austen e James Edward Austen-Leigh não quiseram mostrá-la como uma escritora, mas como uma mulher que vivia dentro dos padrões de feminilidade, uma proper lady, uma preocupação que existiu tanto pelo fato de nunca ter se casado quanto por ter publicado romances, algo incomum para mulheres naquela época. As biografias foram escritas para convencer os leitores de que, mesmo sem ter sido esposa ou mãe, Jane Austen era feminina e virtuosa, e não se afirmava escritora.

Essas biografias contribuem há séculos com a propagação de um ideal de feminilidade, o qual é questionado pela crítica feminista e desestabilizado por estudos culturais. 
Ao construírem imagens de mulheres de suas perspectivas, escritoras modificam ideais de gênero estabelecidos. As personagens femininas criadas por Jane Austen sugerem alternativas sobre ser mulher que divergem das defendidas em livros de conduta. No início do século XIX, a leitura dos romances da escritora pode ter feito com que as imagens das personagens passassem a ser identidades desejadas pelas leitoras. $\mathrm{O}$ fato de existir personagens que questionam de alguma forma o status quo desestabiliza o discurso de naturalização da feminilidade e rompe com representações historicamente propagadas de mulheres. Neste sentido, é importante discutir a imagem de Jane Austen divulgada no século XIX contrapondo-a a documentos revelados nos séculos seguintes e a estudos da academia. Pois, como afirma Funck (2016), somente quando pudermos falar em póspatriarcado, e não em pós-feminismo, não mais precisaremos falar de gênero e ensino.

\section{REFERENCIAS}

AUERBACH, Emily. Searching for Jane Austen. London: University of Wisconsin Press, 2004.

AUSTEN, Jane. Jack e Alice. In: AUSTEN, Jane; BRONTË, Charlotte. Jane Austen e Charlotte Brontë: juvenília. Trad. Julia Romeu. Kindle ed. São Paulo: Penguin Classics, Companhia das letras, 2014. posição 870-1151. CAMPOS, M. C. C. Gênero. In: JOBIM, J. L. (Org.). Palavras da crítica: tendências e conceitos no estudo da literatura. Rio de Janeiro: Imago, 1992, p. 11-125.

FUNCK, S. B. Crítica literária feminista: uma trajetória. Florianópolis: Editora Insular, 2016.

GILBERT, S. M.; GUBAR, S. The madwoman in the attic: the woman writer and the nineteenth-century literary imagination. New Haven e Londres: Yale UP, 2000.

GILSON, D. Henry Austen's “Memoir of Miss Austen”. Persuasions, n. 19, p. 12- 19, 1997. Disponível em: http://jasna.org/publications-2/ persuasions/no19/gilson. Acesso em: 20 abr. 2021. 
HALL, S. Quem precisa de identidade? In: SILVA, T. T. (Org.). Identidade e diferença: a perspectiva dos estudos culturais. Trad. Tomaz Tadeu da Silva. 15. ed. Petrópolis, RJ: Vozes, 2014. p. 103-133.

HARMAN, Claire. Jane's fame: how Jane Austen conquered the world. Kindle ed. Edinburgh: Canongate, 2009.

IRVINE, Robert. Jane Austen. Kindle ed. New York: Routledge, 2005.

LE FAYE, Deirdre. Jane Austen's Letters. 4th edition. New York: Oxford University Press, 2011.

LOOSER, Devoney. The making of Jane Austen. Kindle ed. Baltimore, Maryland: Johns Hopkins University Press, 2017.

POOVEY, Mary. The proper lady and the woman writer: ideology as styles in the works of Mary Wollstonecraft, Mary Shelley, and Jane Austen. Chicago and London: The University of Chicago Press, 1984.

REEF, Catherine. Jane Austen: uma vida revelada. Barueri, SP: Novo Século Editora, 2014.

SILVA, T. T. A produção social da identidade e da diferença. In: SILVA, T. T. (Org.). Identidade e diferença: a perspectiva dos estudos culturais. Trad. Tomaz Tadeu da Silva. 15.ed. Petrópolis, RJ: Vozes, 2014, p. 73-102.

SUTHERLAND, Kathryn (Ed.). A memoir of Jane Austen: and other family recollections. Kindle ed. New York: Oxford University Press, 2002.

TEACHMAN, Debra. Understanding Pride and Prejudice: a student casebook to issues, sources, and historical documents. Greenwood Press, 1997.

WOLLSTONECRAFT, M. Reivindicação dos direitos da mulher. Trad. Ivania Pocinho Motta. São Paulo: Boitempo, 2016.

WOODWARD, K. Identidade e diferença: uma introdução teórica e conceitual. In: SILVA, T. T. (Org.). Identidade e diferença: a perspectiva dos estudos culturais. Trad. Tomaz Tadeu da Silva. 15.ed. Petrópolis, RJ: Vozes, 2014, p. 7-72.

WOOLF, Virginia. Profissões para mulheres e outros artigos feministas. Porto Alegre, RS: L\&PM, 2012.

WOOLF, Virginia. Um teto todo seu. Kindle ed. São Paulo: Editora Tordesilhas, 2014.

ZOLIN, L. O. Crítica feminista. In: BONNICI, T.; ZOLIN, L. O. (Orgs.). Teoria literária: abordagens históricas e tendências contemporâneas. 3. ed. Maringá: Eduem, 2009. p. 217- 242. 


\section{CAPÍTULO 4}

\section{O ROMANCE SOB SUSPEITA: "MADAME BOVARY", DE GUSTAVE FLAUBERT}

Midori Nancy Arasaki Chang

\section{INTRODUÇÃO}

Gustave Flaubert publica Madame Bovary em seis fascículos entre o $1^{\circ}$ de outubro e o 15 de dezembro de 1856 na Revue de Paris. Por causa dessa publicação foi incriminado pelo Ministério Público da França por ofensas à moral pública e à religião, segundo consta no Requisitório do Sr. Advogado Imperial Ernest Pinard (FLAUBERT, 2007, p. 303).

No século XXI nos parece estranho que um escritor seja processado por esse motivo, porém dois séculos atrás isto aconteceu de forma recorrente com vários autores, pois como a professora Andréa Müller expõe, a moral era um critério de avaliação artística naquele período e esse critério se estendeu ao âmbito jurídico que detinha o poder de censurar ou proibir obras (MÜLLER, 2013, p. 102-105). Acreditava-se que os leitores eram influenciados e instruídos pelos textos literários, assim eles poderiam imitar os comportamentos das personagens caso o autor não os alertasse de que estavam diante de uma cena imoral.

Contudo, Flaubert, por meio de seu narrador se limitase a contar-nos a história de Emma Bovary. Apresenta-nos 
Charles Bovary, o senhor Rouault, Emma, Felicité, Homais, Léon, Rodolphe e seus enredos, no entanto, durante a narrativa não guia o leitor, pois omite juízos de valor moral e com isso não o alerta de que está diante de uma imoralidade que não deve reproduzir. Nem mesmo diante das aventuras amorosas de Emma o narrador de Flaubert nos alerta, porém restringe-se a descrever e contar de forma perspicaz, assim deixa livre ao leitor para que julgue a obra.

Os estudos de Yvan Leclerc (1991, p. 30) apontados por Müller (2013, p. 106) nos indicam que a maior parte das obras que sofreram processos judiciais na França no século XIX eram romances. Assim, no momento da publicação de Madame Bovary, o romance era um gênero sob suspeita, carecia de prestígio literário por ser qualificado como um novo gênero, que representava um perigo maior para as camadas populares consideradas mais vulneráveis à sua influência, principalmente mulheres, crianças e jovens. Portanto, um dos agravantes do caso Flaubert, que o levaram aos tribunais, é ter construído sua obra magistral na forma do romance, pois esta decisão nesse contexto constitui uma rebeldia.

A mulher leitora do século XIX era considerada por detratores do romance como influenciável e vulnerável aos efeitos da leitura por ser mais voltada à fantasia e imaginação; por causa de suas leituras se desviaria de suas funções familiares e sociais, que the eram impostas pela cultura desse século (MÜLLER, 2013, p. 107). Consideramos que outro dos agravantes que levaram Madame Bovary e seu autor aos tribunais, é a representação da mulher leitora na personagem principal do romance, ou seja, em Emma Bovary. Qual seria, então, a figura da mulher leitora em Emma, que causou tanto escândalo naquela época e por que assim aconteceu? 
Aproximadamente dez anos antes do começo da escrita de Madame Bovary aconteceu na França, em 1840, o episódio conhecido como "affaire Lafarge" (MÜLLER, 2013, p. 108109). A jovem Marie Cappelle se casou em 1839 com Charles Lafarge e passou a viver numa propriedade em ruínas. Decepcionada pelo casamento, começou a sentir-se entediada. Seu esposo faleceu cinco meses depois da união matrimonial e ela foi acusada de tê-lo envenenado com arsênico. Marie Cappelle-Lafarge foi presa e condenada pelo suposto crime e comentava-se que a leitura de romances a influenciara a cometer o crime imitando a personagem Nathalie do romance Memórias do diabo, de Soulié. É interessante a semelhança dessa história real com a narrativa ficcional de Flaubert. A figura da mulher leitora é retratada em Emma com tal verossimilhança, que se reflete tanto na história de Marie quanto no que se comentava sobre as mulheres leitoras da época.

\section{A FIGURA DA MULHER LEITORA EM MADAME BOVARY}

O caso de Marie Cappelle caracteriza a mulher leitora de inícios do século XIX, pois a acusaram de ter cometido o crime influenciada pela leitura de romances, gênero considerado perigoso e pernicioso por seus detratores, que afirmavam que as mulheres, por suas inclinações ao prazer e à imaginação, imitariam os comportamentos das personagens: adultério, incesto, sedução, crimes (ABREU, 2003, p. 278-279).

Flaubert constrói sua madame Bovary com base nos critérios da época que caracterizavam a mulher leitora e nos entrega sua Emma como uma mulher de inícios do século XIX. É possível contextualizá-la de forma mais concreta na linha temporal pelo evento extraordinário em sua vida, 
o convite do marquês d'Andervilliers (Secretário de estado entre 1814 e 1830) a Vaubyessard, ao seu castelo. Emma ficou deslumbrada e profundamente impressionada com o luxo e as grandezas do castelo e o baile do qual participou. "A viagem a Vaubyessard fizera um buraco em sua vida [...] o pesar permaneceu” (FLAUBERT, 2018, p. 53-63).

A senhorita Emma Rouault era uma mulher culta. Recebera uma bela educação no convento das irmãs Ursolinas e, por isso, sabia dançar, aprendera geografia, desenho, tapeçaria e a tocar piano (FLAUBERT, 2018, p. 27). Emma lera Paul e Virginie antes de completar os treze anos e sonhara com a casinha de bambu, com o negro Domingo, com o cachorro Fiel, com a doce amizade dum bom irmãozinho (IBID, p. 42).

O narrador descreve a senhorita Roualt, aquela jovem no convento, como "de temperamento mais sentimental do que artístico, buscava emoções e não paisagens", apesar de que gostava do mar e conhecia bem o campo, ela "precisava extrair das coisas uma espécie de lucro pessoal e rejeitava, considerando inútil, tudo aquilo que não contribuísse à conservação imediata de seu coração" (FLAUBERT, 2018, p. 44). Observamos aqui a personificação da frágil mulher leitora, que os detratores do romance caracterizaram como facilmente influenciada pela sua inclinação ao prazer e à imaginação.

A jovem Emma conhece no convento uma mulher solteirona leitora de romances que os emprestava às escondidas às meninas maiores. Eram histórias de amores, amantes, damas perseguidas, lágrimas, beijos, homens virtuosos, entre outras. Aos quinze anos, durante seis meses, a protagonista já lia nos velhos gabinetes de leitura Walter Scott, cultuara mulheres como Mary Stuart, Joana d'Arc, Heloísa, Agnès 
Sorel, Ferronnière e Clémence Isaure, entre inúmeras leituras de coisas históricas (FLAUBERT, 2018, p. 44-45).

A respeito dessa passagem da vida da personagem, o linguista francês Vincent Jouve, em sua análise "Emma e a gordura dos livros", destaca a importância da seguinte frase do enredo escrito por Flaubert (2018, p. 44): "Durante seis meses, aos quinze anos, Emma sujou ${ }^{1}$ suas mãos com a poeira dos velhos gabinetes de leitura”. Para Jouve (2012, p. 36-37) a relevância desta frase está em sua função de ser uma síntese das páginas precedentes do romance: "Ela condensa aquilo que, aos olhos do narrador, merece ser enfatizado da adolescência de Emma", desse modo, continua o estudioso francês, o narrador nos indica que estamos lidando com um núcleo da história. Portanto, a figura da mulher leitora em madame Bovary é essencial nessa narrativa de Flaubert, e é precisamente essa representação em Emma uma das circunstâncias que colocaram seu romance sob suspeita.

O pesquisador francês destaca também que na dupla anteposição temporal na frase: Durante seis meses, aos quinze anos, Flaubert, na voz de seu narrador, sublinha um duplo excesso, ou seja, Emma lê por demasiado tempo e é jovem demais para essas leituras, e, além disso, a antítese entre a juventude da personagem e a antiguidade dos velhos gabinetes, assinala que Emma não está em seu lugar (JOUVE, 2012, p. 36). É pertinente destacar que na análise do linguista, a personificação de Emma como essa mulher leitora, que os detratores do romance criticavam e temiam é descrita conforme nossa percepção de que Flaubert teria construído sua personagem segundo os padrões das críticas sociais, culturais e literárias da época, o qual intensifica a desconfiança em seu romance.

1. Na tradução do texto de Jouve se utiliza o termo engordurou. 
A advertência que o pesquisador francês levanta em relação a essa frase do enredo de Flaubert é relevante para nossa reflexão sobre as críticas das quais Madame Bovary foi alvo, pois teriam os detratores do romance do século XIX razões suficientes para acusar o romancista francês de ofensa à moral pública e à religião e colocá-lo como réu na justiça? A advertência de Jouve (2012, p. 38) é a seguinte:

Resta a questão de saber se o enunciado deve ser tomado em sentido próprio ou em sentido figurado. As duas hipóteses parecem igualmente aceitáveis: Emma sujou as mãos, no sentido próprio, por causa da poeira que impregna esses livros vindos de velhos gabinetes mal conservados; Emma se impregna, no sentido figurado, do conteúdo de livros antiquados que a marcaram por toda a vida.

Concordamos com Jouve, porém, se tanto o sentido literal quanto o figurado são aceitáveis no enredo da personagem, cabe questionar-nos se os detratores do romance do século XIX, que colocaram a narrativa de Flaubert sob suspeita, estariam certos em seus argumentos ao alertar que a representação artística da figura da mulher leitora em Emma era um perigo às mulheres leitoras da sociedade daquela época por causa da sua influência imoral. É possível afirmar que, no contexto desse século, a indignação que o romance de Flaubert causou se justifica nos costumes e convenções sociais e culturais, que posteriormente se fragilizaram, mas não na fragilidade das mulheres, que as faria alvos de influência.

$\mathrm{Na}$ continuação do enredo, o narrador descreve Emma Roualt, às vésperas de seu pai a retirar do convento, da seguinte forma: "Aquele espírito positivo em meio a seus entusiasmos, que amara a igreja pelas flores, a música pelas letras de romanças e a literatura pelas excitações passionais, 
insurgia-se diante dos mistérios da fé, do mesmo modo que se irritava contra a disciplina, que era algo antipático à sua constituição" (FLAUBERT, 2018, p. 47). Assim, Flaubert faz de Emma a figura da mulher leitora que os detratores tanto criticavam, pois, preocupados com a moral, diziam que "sua leitura provocaria sensações físicas pouco recomendáveis no leitor, inflamando desejos, despertando volúpia, excitando, enfim, os sentidos" (ABREU, 2003, p. 278).

Entretanto, Marcia Abreu (2003, 284-285) aponta que os perigos mais sérios percebidos pelos detratores do romance e que colocavam em risco principalmente as mulheres leitoras, foram: a confusão entre realidade e ficção; a frustração com relação à própria vida, julgada pouco interessante quando comparada às narrativas; o desejo de fazer, na vida real, o mesmo que fazem os personagens.

Flaubert constrói a história de Emma e a coloca frente a esses três perigos que as mulheres leitoras do século XIX enfrentariam ao lerem romances. Madame Bovary experimenta a frustração logo no início de seu casamento com Charles. Emma repetia: Por que fui me casar? E se perguntava se não haveria um meio de encontrar outro homem (FLAUBERT, 2018, p. 52). Eis aqui um dos motivos que causavam frustração em Emma com relação a sua própria vida.

Emma repelia o marido, pois antes de se casar pensava que o amava, mas a alegria produto desse amor não aparecia e "Emma buscava saber o que significavam exatamente, na vida, as palavras felicidade, paixão e embriaguez, que tão belas lhe pareciam nos livros" (FLAUBERT, 2018, p. 42). Observamos aqui o perigo de confundir a realidade e a ficção e o desejo de fazer na vida real o que os personagens fazem na ficção, pois a pobre Emma buscava as sensações (felicidade, paixão e embriaguez) que a impactaram na leitura de romances. Assim, 
no decorrer do relato, seremos testemunhas de seus deslizes e excessos aparentemente por ser leitora de romances.

É pertinente apontar que Flaubert coloca principalmente suas leitoras - mas também seus leitores -, diante da possibilidade de perigos na vida real, mas que se ativariam caso elas (ou eles) vivessem o que Jouve (2002, p. 109) descreve como uma das experiências mais emocionantes da leitura, que ele chama de vertigem, essa sensação, nem sempre agradável, pois perturba e fascina ao mesmo tempo, já que consiste em ser quem não somos, por meio da interiorização do outro, ao identificar-nos ou diferenciar-nos da personagem. Isto, explica o professor francês, desestabiliza o leitor. Entretanto, é necessário esclarecer que esses perigos se ativariam no momento da leitura, e que logo ao encerrar esse tempo, o leitor volta a sua cotidianidade.

No intuito de tentarmos esclarecer a figura de mulher leitora em Emma, e o efeito que a leitura do romance poderia causar em suas leitoras - e leitores -, refletimos com Jouve (2002, p. 107) sobre o vivido da leitura:

$\mathrm{O}$ que acontece quando se lê um livro? Quais são as sensações, as impressões que a leitura suscita em nós? Parece que a relação com o texto permite, em primeiro lugar, essa experiência particular que Jauss (1978) chama de 'fruição estética': 'Na atitude de fruição estética, o sujeito é libertado pelo imaginário de tudo aquilo que torna a realidade de sua vida cotidiana constrangedora' (p. 130). [...] A leitura é, portanto, ao mesmo tempo, uma experiência de libertação ('desengaja-se' da realidade) e de preenchimento (suscitase imaginariamente, a partir dos signos do texto, um universo marcado por seu próprio imaginário). 
Com base nos estudos de Jouve, que nos dão a ideia da leitura como uma experiência de libertação da nossa realidade, por meio do imaginário, é possível que nossa reflexão nos leve a cogitar nos argumentos dos detratores do século XIX, que alertaram de perigos desse tipo em mulheres, jovens e crianças, ao considerá-los mais frágeis e susceptíveis de serem presas fáceis da sua fantasia e imaginação. Contudo, nossa breve análise se encaminhará no intuito de refletir sobre a oposição que Gustave Flaubert representou em sua época no plano literário e cultural, o que nos conduz a pensar nas possíveis motivações de seus acusadores no tribunal da França e a colocação de seu romance Madame Bovary sob suspeita.

\section{A OPOSIÇÃO DE FLAUBERT AO LITERÁRIO E CULTURAL DE SEU TEMPO}

Tentaremos apenas refletir sobre o assunto, pois é tarefa impossível chegar ao âmago das intenções do autor em seu romance.

A oposição de Flaubert se apresenta no plano literário e cultural da época. O literário será discutido com base em três questões: Madame Bovary na forma de romance, Emma como uma mulher leitora do século XIX e um narrador que se limita a relatar a história sem alertar-nos sobre a moral. O aspecto cultural da oposição de Flaubert é assunto do tópico seguinte.

Para discutir a primeira questão desta oposição do autor ao escrever Madame Bovary na forma de romance é necessário lembrar o que Ian Watt expõe a respeito: o termo romance só se consagrou no final do século XVIII e o "realismo" é 
a diferença essencial entre a obra dos romancistas do início do século XVIII e a ficção anterior. O realismo do gênero romance "procura retratar todo tipo de experiência humana e não só as que se prestam a determinada perspectiva literária: seu realismo não está na espécie de vida apresentada, e sim na maneira como a apresenta". O gênero romance surgiu na modernidade afastando-se de sua herança clássica e medieval e tentando rejeitar os universais. A originalidade e novidade do romance é representar a experiência humana de forma individual, assim os escritores não mais extraíam suas narrativas da História, da mitologia, da lenda ou de fontes literárias do passado. O uso de enredos não tradicionais, ou inteiramente inventados ou baseados parcialmente num incidente contemporâneo se tornaria a prática geral do romance (WAT'T, 1990, p.12-16).

Madame Bovary foi publicado em 1856 quando o romance estava em polêmica ascensão, porém não gozava de prestigio literário por seus autores deixarem o modelo clássico e tradicional para narrar experiências humanas individuais, tal como Flaubert, que nos deixa o relato da experiência individual de Emma, uma história como a de qualquer mulher, com seus encantos e desencantos, seus sonhos e frustrações como o é a própria vida. Eis aqui Flaubert e sua oposição na forma de romance.

Contudo, Ian Watt afirma que o romance se diferencia dos outros gêneros e de formas anteriores de ficção pela individualização das personagens e a detalhada apresentação de seu ambiente (WATT, 1990, p. 19). Seguindo estas características do romance sob suspeita, Flaubert constrói suas personagens sobre a base de pessoas individuais e não como grandes heróis clássicos. Temos assim Emma (uma camponesa), Charles (um esposo apaixonado), Homais (o 
boticário), Felicité (a criada), Rodolphe e León (os amantes), entre outros. Pessoas comuns com nomes próprios que as identificam e as individualizam.

A detalhada apresentação dos ambientes é outra das características que este romance sob suspeita descreve. Para ilustrar achamos, no início da segunda parte da obra, a descrição detalhada de Yonville-l'Abbaye. O narrador nos conta detalhes da localização do pequeno vilarejo onde Emma e Charles se mudaram e onde acontece a maior parte da história e seu trágico fim. As características da estrada, os lugares por onde os personagens passam, dados históricos da cidade, descrições geográficas, paisagens naturais, a agricultura na cidade, a ponte, a calçada, as casas da região e seus telhados de palha, a igreja que fica do outro lado da rua, a praça, o cemitério, o mercado, a prefeitura, a casa do farmacêutico e sua farmácia, a única rua do vilarejo, enfim, são tantos detalhes que não cabem neste texto (FLAUBERT, 2018, p. 74-77). Dessa forma, no decorrer da narrativa nos deparamos com inúmeras e minuciosas descrições dos ambientes.

Porém, segundo Ian Watt “as personagens do romance só podem ser individualizadas se estão situadas num contexto com tempo e local particularizados", a forma de isto acontecer no romance moderno é "o desenvolvimento de suas personagens no curso do tempo" distinguindo-se por "utilizar a experiência passada como a causa da ação presente" (WATT, 1990, p. 22-23).

Conforme os esclarecimentos de Ian Watt, é possível contextualizar a história de Emma num tempo e espaço definidos, pois a personagem se situa no início do século XIX e em espaços delimitados na narrativa.

Sendo assim, a senhorita Emma Roualt, filha de um fazendeiro de Bertaux (a duas léguas de Tostes), educada no 
convento das irmãs Ursolinas, se casa com Charles Bovary, se muda para Tostes e logo para Yonville onde se suicida tomando arsênico (FLAUBERT, 2018).

Observamos também que Flaubert caracteriza Emma no curso do tempo de sua vida particular e utiliza o passado como causa de sua ação presente ao narrar os detalhes de sua educação no convento, suas leituras, seu tédio na fazenda do pai, descrevendo-a como sentimental para, no decorrer de sua história e como consequência desse passado, apresentarnos uma madame Bovary que repele o marido, comete adultério, deseja uma vida luxuosa e finalmente se suicida numa contínua linha do tempo e espaço da vida particular de sua personagem. Isto significa que a caracterização de Emma e Charles nos explicam os motivos das suas decisões, experiências e o desenlace de sua história (FLAUBERT, 2018). É possível apontar a experiência passada como explicação do presente segundo Ian Watt nos explica.

Contudo, a oposição de Flaubert se dá também na figuração da mulher leitora em Emma segundo as descrições dos detratores do romance da época, porém é pertinente questionar-nos se teria a leitura de romances tamanha influência e efeitos sobre as frágeis leitoras ao ponto de levalas a cometer adultério e suicídio, pois mesmo refletindo sobre o impacto da leitura com base no estudo do linguista francês Vincent Jouve, nos parece pouco provável uma influência a tal extremo sobre as leitoras e leitores.

Defendemos a ideia de que Flaubert constrói Emma para contrariar os detratores do romance colocando suas críticas no espelho do romance, refletindo verdades por demais cruéis, pois, segundo Walter Siti, no final do século XVIII acontece uma aparente inversão de trajetória do romance, que até aquele momento tinha sido acusado sobretudo de mentir, 
porém "desse momento em diante será acusado de dizer verdades por demais cruéis", fornecendo "à burguesia o mais convincente dos espelhos" (SITI, 2009, p.182-184).

Flaubert, ao personificar Emma como uma mulher leitora da época, interroga seus detratores sobre suas críticas. Seriam as mulheres tão frágeis diante de sua própria imaginação e prazer que influenciadas pela leitura de romances cometeriam adultério e suicídio, abandonariam seus afazeres no lar, deixariam de amar o marido por compará-lo com os heróis das narrativas? Estas experiências são vividas pela personagem, contudo será que Flaubert concordava com os detratores do romance? Acreditamos que não, ele nos entrega Emma como mulher leitora para discordar deles. Eis a segunda questão de sua oposição.

O fundamento da nossa posição está na motivação pela qual Emma se envenena com arsênico. Por trás dessa figuração da mulher leitora encontramos mais do que uma frágil mulher com uma fértil imaginação e com tendência aos prazeres. É verdade que ela se decepciona com seu casamento porque deseja experimentar o amor e as emoções da ficção, contudo Emma demonstra ansiedade e angústia, um vazio em sua vida. No início foi o amor e as emoções no casamento, seu desejo de conhecer e viver em Paris, logo o luxo e o prestigio social ansiando ter uma vida que não correspondia a suas condições sociais e econômicas, o desejo do prestigio profissional de Charles, com o qual ela também se beneficiaria, e o adultério consumado com Rodolphe e Léon seria mais um de tantos desejos que Emma ansiava.

A prova disto é que ela se envenena por causa da ruína financeira, pois perderia seus bens, ficaria na miséria e passaria por vergonha pública. Desesperada depois de várias tentativas e humilhações por conseguir a altíssima soma de 
dinheiro para cobrir sua dívida, toma o arsênico e espera a terrível morte diante do desespero e tristeza de Charles. Este é o mais convincente dos espelhos que nos mostra as mais cruéis verdades da humanidade retratada em Emma.

A metáfora do romance (ou a literatura) como o veneno adicionado a uma bebida agradável era usado por seus detratores (MÜLLER, 2013, p. 115-116) e Flaubert mata Emma com arsênico, além de fazer com que Homais justifique esse envenenamento em seu artigo para o Fanal com a história (mentirosa) de que ela teria confundido o pó branco do arsênico com açúcar ao preparar um creme de baunilha (FLAUBERT, 2018, p. 313-314).

Contudo, o veneno que matou madame Bovary não foi o veneno de suas leituras de romances, "aquele gosto horrível de tinta" (FLAUBERT, 2018, p. 303), e sim o veneno da terrível angústia e ansiedade, a busca por satisfazer seus desejos, luxos e paixões, sua terrível ânsia por liberdade, "um sabor amargo que sentiu na boca" (FLAUBERT, 2018, p. 302), que termina levando Emma ao desespero extremo de acabar com sua vida de forma dolorosa e lenta. Eis um retrato da nossa humanidade, de nossas angústias e ansiedades.

Como mencionamos, o romance foi alvo de duras críticas e, segundo Walter Siti, "Entre todos os gêneros literários, o romance é o único que tem necessidade de renegar-se a si mesmo." e para desculpar-se ou justificar-se são usados os paratextos (prefácios, notas, posfácios, advertências do editor etc.), pois o romance era um gênero desacreditado, "ele faz com que se perca a cabeça, enlouquece a pessoa” (SITI, 2009, p. 168-176). Esta prática era recorrente entre os escritores contemporâneos a Flaubert, porém o romancista francês não se preocupa em deixar-nos prefácios, notas, posfácios ou advertências renegando seu romance e nem afirma, como 
outros, que "este não é um romance, é um fato verídico", na tentativa de "com a aparência de verdade enganar seus leitores" (SITI, 2009, p. 182). Pelo contrário, Flaubert assume sua obra como romance, rompendo com os moldes clássicos literários e já na terceira questão de sua desobediência (o narrador que não alerta o leitor) concordamos com Pinard, o promotor que acusou Flaubert, quando nos diz, em seu requisitório: "Quem pode condenar essa mulher no livro? Ninguém. Esta é a conclusão. Não há no livro nem um personagem que possa condená-la” (FLAUBERT, 2007, p. 317).

Nós adicionamos as palavras de Pinard, que não há nem narrador e nem autor que possa condenar Emma Bovary no romance e que alerte o leitor que está diante de cenas imorais, de cenas de adultério, ninguém na obra que faça um juízo de valor moral ou religioso.

Essa estratégia do autor nos remete a um dos "três elementos precoces" da teoria do romance de Flaubert: "a ideia de que o romance deve mostrar, não julgar", segundo Mario Vargas Llosa aponta em seu minucioso estudo A orgia perpetua (VARGAS, 1979, p. 73) e que corresponde à "teoria da impessoalidade" do escritor francês que descreve na carta a Louise Colet, datada no dia 08 de fevereiro de 1852, no tempo em que escrevia Madame Bovary: “[...] Quero que não haja em meu livro um só movimento, nem uma só reflexão do autor [...]" (VARGAS, 1979, p. 53, o grifo é de Flaubert). Contudo, a ausência de reflexão do autor, na voz do narrador, constitui uma oposição aos padrões literários da época, pois o francês, ao assumir essa estratégia, deixa livre seu leitor para que julgue a obra.

Nossa reflexão até este momento se deteve na oposição de Flaubert no plano literário, o que lhe ocasionou duras críticas e colocou seu romance Madame Bovary no banco dos 
réus. Nos parágrafos a seguir dialogaremos brevemente sobre a oposição do romancista francês no plano cultural do século XIX, tempo em que escreveu e publicou sua obra magistral.

\section{A OPOSIÇÃO CULTURAL DE FLAUBERT NA INVERSÃO DA HIERARQUIA HOMEM/MULHER}

Neste tópico trataremos brevemente da oposição de Flaubert a partir do contexto cultural de sua personagem e, para tanto, a estratégia filosófica da desconstrução, exposta por Jonathan Culler, auxiliará nossa análise, pois:

Em uma tradicional oposição filosófica não temos uma pacífica coexistência de termos contrapostos, mas uma violenta hierarquia. Um dos termos domina o outro (axiologicamente, logicamente etc.), ocupa a posição de comando. Desconstruir a oposição é, acima de tudo, reverter a hierarquia em determinado momento" (CULLER apud DERRIDA, 1997, p. 99).

Em Madame Bovary observamos a hierarquia homem/ mulher, uma oposição na qual o termo homem domina sobre o termo mulher, isso significa que na realidade cultural de Emma ser homem significa dominar a mulher, que assume um papel de submissão. Analisaremos sucintamente a forma como Flaubert inverte esta oposição trazendo o termo dominado (mulher) para um papel dominante (homem) na construção de sua personagem.

Nas palavras de Llosa, em Madame Bovary "Há outra inversão de substâncias, igualmente discreta: algumas mulheres e varões trocam de sexo" e, referindo-se a Emma, nos diz que "sob a delicada feminilidade dessa moça, 
embosca-se um decidido varão" (VARGAS, 1979, p. 109). O escritor peruano nos explica com clareza as condições da personagem em seu papel de mulher:

A tragédia de Emma é não ser livre. A escravidão acontece-lhe não apenas como produto de sua classe social - pequena burguesia caracterizada por determinadas condições de vida e preconceitos - e de sua condição provinciana - mundo diminuto em que são escassas as possibilidades de fazer algo -, mas também, e talvez, acima de tudo pelo fato de ser mulher (VARGAS, 1979, p. 109).

O fato de ser mulher, na realidade fictícia, segundo o literato peruano, "constrange, fecha portas, condena a opções mais medíocres que as do homem" (VARGAS, 1979, p. 109). Entretanto, Flaubert constrói sua Emma com desejos grandiosos de liberdade, a coloca com sonhos de viver com os privilégios dos homens daquela época e, decidida a concretizar seus desejos, a vemos grávida desejando um filho homem:

[...] era como a revanche de todas suas impotências passadas. Um homem ao menos é livre; pode percorrer as paixões e os países, atravessar os obstáculos, ir atrás das alegrias mais distintas. Mas uma mulher é constantemente impedida. Ao mesmo tempo inerte e flexível, a mulher tem a seu desfavor as fraquezas da carne e as dependências da lei (FLAUBERT, 2018, p. 92).

Assim pensava Emma sobre sua condição de mulher. Por isso, seu desejo de ter um filho varão e o desejo de ela mesma viver na condição de homem. Assim, a achamos com amargura porque "a mediocridade doméstica a conduzia a fantasias luxuosas, a ternura matrimonial, a desejos adúlteros” 
(FLAUBERT, 2018, p. 110), deleitando-se com a ideia de possuir os prazeres do amor ("Tenho um amante! Um amante!) (IBID, p. 160), passeando com Rodolphe "com um cigarro na boca, como se quisesse desafiar a sociedade", descendo da Hirondelle "com o busto apertado em um colete à moda masculina” (IBID, p. 187-188), convencida por León a subir ao fiacre (carruagem) com o argumento de que "Em Paris todo mundo faz isso!" (IBID, p. 236), obtendo de Charles uma autorização para "gerir e administrar os negócios, fazer todos os empréstimos, assinar e endossar todas as promissórias, pagar todas as somas etc." (IBID, p. 246).

Flaubert, em sua oposição aos padrões culturais de sua época, não se limita às roupas masculinas da personagem e a seus desejos, mas faz de Emma uma mulher dominante que "mal nota um sintoma de fraqueza do varão, passa ela a assumir funções varonis e impõe àquele atitudes femininas" (VARGAS, 1979, p. 111).

Desse modo, Emma domina seu marido, que faz todas suas vontades, toma a iniciativa com León, pois é ela que vai a seu encontro e divide os gastos do hotel onde se amam. Observamos a forma como Flaubert concede a Emma desejos de ter as condições de homem, de dominar, de ser livre da escravidão da mulher que a reduzia à submissão e às tarefas domésticas. Assim, o romancista francês inverte a hierarquia homem/mulher em Emma, uma mulher dominante na posição inconsciente de homem que busca e deseja ardentemente sua liberdade, e precisamente sua tragédia é essa, pois não a consegue e se enreda em seus próprios desejos, paixões e sonhos, chegando à ruina financeira que a levam a sua terrível morte por suicídio.

Acreditamos que a inversão da hierarquia homem/ mulher na representação artística de Emma Bovary, que a 
configura como uma mulher dominante com desejos de viver nas mesmas condições e com os mesmos privilégios masculinos de seu tempo, mas sem perder sua feminilidade, deixa em evidência a oposição de Flaubert no plano cultural de sua época, oposição que até os dias de hoje, no transcorrer do século XXI, ainda nos deixa úteis reflexões por tratar de profundas experiências humanas, que atingem tanto mulheres quanto homens de qualquer tempo, só mudam as causas, porém as angústias e ansiedades permanecem.

\section{CONSIDERAÇÕES FINAIS}

Depois de conseguir a absolvição do Tribunal da França, Flaubert publica Madame Bovary em livro, em 1857. O estilo flaubertiano que burila palavra por palavra, frase por frase nos legou uma personagem universal e humana: Emma Bovary que "[...] resume em sua personalidade atormentada e sua medíocre peripécia, certa postura vital e permanente, capaz de aparecer sob roupagens mais diversas e em diferentes épocas e lugares [...]", porque nela se resume também "[...] uma das mais privativas postulações do humano, da que resultam todas as façanhas e todos os cataclismos do homem: a capacidade de fabricar ilusões e a louca vontade de realizá-las" (VARGAS, 1979, p. 30). Madame Bovary sou eu, teria dito Flaubert. Levou quase cinco anos para construir sua Emma, porém sabemos que não é ele, contudo colocou nela as angústias e ansiedades humanas com seus desejos e sonhos e com a vontade determinada de alcançá-los. Eis o resumo de Emma Bovary, uma mulher como qualquer outra que sobrepassa seu tempo e chega até hoje. 


\section{REFERENCIAS}

ABREU, Marcia. A leitura do romance. In: ABREU, Marcia. Os caminhos dos livros. Campinas-SP: Mercado de Letras, Associação de Leitura do Brasil (ALB); São Paulo: FAPESP, 2003, p. 265-310.

CULLER, Jonathan. A desconstrução. In: CULLER, Jonathan. Sobre a desconstrução. Teoria e crítica do pós-estruturalismo. Tradução de Patrícia Burrowes. Rio de Janeiro: Record: Rosa dos tempos, 1997, p. 99-259.

FLAUBERT, Gustave. Madame Bovary. Tradução de Ilana Heineberg. Porto Alegre, RS: L\&PM, 2018.

FLAUBERT, Gustave. O Processo. In: FLAUBERT, Gustave. Madame Bovary. Costumes de província. Tradução de Fúlvia M. L. Moretto. São Paulo: Nova Alexandria, 2007, p. 301-360.

JOUVE, Vincent. A leitura. Tradução de Brigitte Hervot. São Paulo: UNESP, 2002.

JOUVE, Vincent. Por que estudar literatura? Tradução de Marcos Bagno e Marcos Marcionilo. São Paulo: Parábola, 2012.

MÜLLER, Andréa Correa Paraiso. Moral e arte literária no século XIX: o romance sob suspeita. Polifonia, Cuiabá-MT, v. 20, n. 28, p. 101-131, jul./dez. 2013.

SITI, Walter. O romance sob acusação. In: MORETTI, Franco (org.). A cultura do romance. Tradução de Denise Bottmann. São Paulo: Cosac Naify, 2009, p. 165-195.

VARGAS Llosa, Mario. A orgia perpétua. Flaubert e "Madame Bovary". Tradução de Remy Gorga filho. Rio de Janeiro: F. Alves, 1979, p. 1-113.

WATT, Ian. O realismo e a forma do romance. In: WATT. Ian. A ascensão do romance. Estudos sobre Defoe, Richardson e Fielding. Tradução de Hildegard Feist. São Paulo: Companhia das Letras, 1990, p. 11-33. 


\section{CAPÍTULO 5}

\section{UM "CANTINHO" PARA AS "AMÁVEIS LEITORAS": DISCURSOS SOBREA MULHER NA REVISTA POPULAR (1859-1862)'}

Andréa Correa Paraiso Müller (UEPG)

\section{INTRODUÇÃO}

Em meados do século XIX, a despeito do alto índice de analfabetismo, o Brasil contava com leitores suficientes para estimular a produção do considerável número de periódicos que por aqui circulavam, desde os jornais diários até panfletos críticos, passando pelas revistas ilustradas e revistas literárias (SODRÉ, 1999; MARTINS \& LUCA, 2013). A reduzida longevidade de muitos desses periódicos sugere que o público talvez não fosse tão vasto e precisasse ser conquistado.

As revistas intensificaram seu sucesso e diversidade de títulos em meados do Oitocentos. Ana Luíza Martins (2013) relaciona o êxito dessas publicações à sua capacidade de atingir novos públicos:

A modalidade se fez presente já nos primeiros anos da Impressão Régia, persistiu no Império e se difundiu como

1. Este artigo originou-se da ampliação e do aprofundamento da comunicação "A imagem da mulher leitora no periódico oitocentista Revista Popular" apresentada oralmente, por mim, no X CIEL, no âmbito do simpósio "Representações da mulher leitora e da leitura feminina". 
gênero de sucesso no país. $O$ caráter de leitura ligeira e amena, acrescido do recurso da ilustração, adequavam-na ao consumo de uma população sem tradição de leitura, permitindo a assimilação imediata da mensagem (MARTINS, 2013).

Em meio à variedade de jornais e revistas circulando no Brasil oitocentista, uma quantidade nada desprezível era destinada ao público feminino. Constância Lima Duarte, em Imprensa feminina e feminista no Brasil - século XIX (2016), identifica 143 títulos de periódicos femininos que circularam no país no decorrer de todo o século XIX. Uma boa parte desses periódicos destinados às mulheres eram editados e redigidos por homens. É o caso do primeiro periódico voltado especialmente para as leitoras no Brasil, O espelho diamantino, fundado no Rio de Janeiro por Pierre Plancher em 1827. Os jornais e revistas elaborados por mulheres e dedicados a abordar questões de interesse específico feminino surgiram somente em meados do século XIX (DONEGÁ, 2013, p. 46).

A Revista Popular (1859-1862), da prestigiosa editora Garnier, do Rio de Janeiro, não era um impresso voltado exclusivamente para as mulheres, mas as visava como parte de seu público. Apresentava-se como um periódico diversificado, que, em meio ao amplo leque de assuntos abordados, reservava um "cantinho" para as "amáveis leitoras", como veremos mais tarde. Interessa, neste artigo, identificar e problematizar alguns pensamentos sobre a mulher que são expressos nesse periódico, não apenas nas seções explicitamente destinadas ao leitorado feminino, mas também nos textos que se referiam às mulheres ou à sua educação. O intuito é compreender e discutir em que medida a revista partilhava da ideia, amplamente aceita e difundida na 
época, segundo a qual as mulheres seriam leitoras vulneráveis, com pouco preparo intelectual e suscetíveis à influência de leituras mal escolhidas.

Para realizar esta pesquisa, foi consultada a íntegra dos exemplares digitalizados da Revista Popular no site da Hemeroteca Digital Brasileira. O estudo encontra suporte e contextualização em trabalhos de história da leitura, particularmente pesquisas que têm como objeto a imprensa no Brasil oitocentista.

\section{A REVISTA POPULAR}

Empreendimento da renomada casa Garnier, a Revista Popular circulou quinzenalmente, de janeiro de 1859 a dezembro de 1862, quando foi sucedida pelo Jornal das Famílias (1863-1878). Durante seus quatro anos de atividade, abordou os mais variados temas: da História à Economia, da Física à Música, da Agricultura à Literatura e à Crítica Literária. Além dos primeiros escritos de alguns jovens literatos (MÜLLER, 2017), veiculou textos de colaboradores bastante respeitados, figuras de destaque nos meios letrados da corte, entre os quais Joaquim Norberto de Sousa e Silva, o romancista Joaquim Manuel de Macedo e o cônego Joaquim Caetano Fernandes Pinheiro, professor do prestigioso colégio Pedro II.

O renome de seus colaboradores, a notoriedade da editora Garnier e o período relativamente longo de sua circulação permitem supor que as ideias defendidas na Revista Popular encontravam acolhida entre o público, refletindo, provavelmente, o pensamento de boa parte dos homens de letras de então. Nelson Werneck Sodré chegou a referir-se a ela, em sua História da Imprensa no Brasil, 
como "uma das publicações mais conceituadas do tempo" (SODRÉ, 1999, p. 92).

É importante notar que esse primeiro periódico da editora Garnier situa-se em um momento da história da leitura no Brasil em que a circulação de traduções de romances estrangeiros, particularmente franceses, era intensa e preocupava muitos literatos, que viam a ficção estrangeira como concorrência junto aos leitores para as produções brasileiras. Como diversas outras revistas do período, a publicação manifestava o intuito de "produzir e divulgar a então nascente literatura pátria” (LIMA, 2008, p. 89).

No texto de apresentação do primeiro número da revista, esse compromisso com a literatura nacional explicitava-se: "Longe de banir a literatura estrangeira, dar-lhe-emos generosa hospitalidade, mas nunca nos esqueceremos de que escrevemos no Brasil e em língua portuguesa. Não correremos os de casa para afagar os de fora" (REVISTA POPULAR, 1859, p. 3). Esse empenho em dar espaço e destaque a autores brasileiros não se manifestava apenas no texto de apresentação, mas reiteravase em diversos artigos publicados ao longo dos quatro anos de circulação do periódico.

Maria Eunice Moreira ressalta a importância da Revista Popular em relação a outras revistas literárias brasileiras e salienta o endosso do periódico ao programa nacionalista:

Nenhum desses periódicos, porém, tem a importância e a circularidade da Revista Popular, fundada no Rio de Janeiro, em 1859. Órgão do Romantismo, a Revista Popular é considerada, no período de sua circulação, que se estende até 1862, o centro dinâmico na renovação das ideias literárias. $\mathrm{O}$ interesse da revista pelos assuntos nacionais e o endosso ao programa 
nacionalista pode ser comprovado pelas publicações de um de seus colaboradores mais assíduos: Joaquim Norberto de Sousa e Silva² (MOREIRA, 1996, p. 54).

A preocupação em valorizar e estimular a literatura nacional é visível em grande parte - senão na maior parte - dos artigos publicados pela Revista Popular e parece configurarse como um critério para a apreciação das obras que ali seriam recomendadas ou resenhadas. No entanto, não era o único. Ainda no texto de apresentação do primeiro número, um outro importante critério era apresentado - a moral:

Nem sempre seremos pois sérios, procuraremos também contribuir para o recreio dos nossos leitores. Mas recreando pode-se instruir disfarçadamente, não nos esqueçamos disso. $\mathrm{O}$ recreio, que se busca nos livros, deve ser uma instrucção amena (REVISTA POPULAR, 1859, p. 3) $)^{3}$.

A moral era um dos principais critérios na avaliação da literatura, especialmente dos romances, até meados do século XIX (MÜLLER, 2013; ABREU, 2014; ALMEIDA, 2013). Na concepção vigente, a literatura era capaz de influenciar o comportamento dos leitores e, por isso, só eram recomendáveis os textos que pudessem cumprir o princípio horaciano de "instruir deleitando" e não reforçassem condutas moralmente reprováveis. No último número de 1860 da Revista Popular, em um texto que comemorava os

2. Figura importante nas discussões sobre nacionalismo e autonomia da literatura brasileira, Joaquim Norberto de Sousa e Silva publicou na Revista Popular os capítulos esparsos do que seria a sua História da Literatura Brasileira, obra que ele não chegou a concluir, além de outros artigos, como a série "Brasileiras célebres", que se tornaria livro. Em seus textos, a defesa de um projeto de literatura nacional fica clara.

3. Nas citações de textos de fontes oitocentistas, será mantida a grafia original. 
dois anos do periódico, o compromisso com a publicação de romances morais era reforçado:

Escrupulosa na observancia dos principios da moralidade não tem esta publicação, destinada às familias, se afastado de seus compromissos, que tão benigna e espontanea proteção lhe valeu da parte do sexo amavel. Mais do que as fortes emoções, mais do que os quadros de terrivel realidade, procura em seus romances que triumphe a virtude, não permittindo sequer por um instante que se possa vacillar na opção entre ella e o vicio (REVISTA POPULAR, 1860, p. 5).

Ao basear na moralidade a escolha dos textos a publicar, a Revista Popular alinhava-se aos critérios empregados dentro e fora do Brasil. A moral era parâmetro importante para a crítica literária veiculada na imprensa do Ocidente, sobrepondo-se até mesmo à forma e ao cuidado com a escrita. Sustentava-se que obras bem escritas que apresentassem exemplos de conduta reprováveis não deixavam de ser perniciosas, como se observa nessa afirmação do crítico francês Antonin Rondelet, em artigo publicado na Revue Contemporaine, em 1863: "Se elas [as obras] falam contra o dever, a beleza de sua forma não salva a imoralidade de sua concepção" (RONDELET, 1863, p. 531).

Em meados do século XIX, a moralidade ou imoralidade da literatura não interessava apenas aos críticos e escritores. Não era incomum que religiosos e magistrados se manifestassem sobre textos ficcionais, recomendando-os ou reprovando-os (MÜLLER, 2012). Na França havia, inclusive, uma lei, promulgada em 1819, que determinava punição a escritores e/ou editores de obras que fossem consideradas imorais (LECLERC, 1991). Com base nessa lei, alguns 
escritores hoje canônicos foram processados sob acusação de imoralidade; os casos mais conhecidos são o de Gustave Flaubert e o de Charles Baudelaire, ambos processados em 1857, pelo romance Madame Bovary e pelo livro de poemas Flores do mal, respectivamente.

O romance, gênero então emergente, que atingia públicos novos outrora sem acesso à leitura, era ainda mais cobrado do que outras composições em relação à moral. Certas parcelas da população, especialmente as mulheres, eram consideradas mais vulneráveis à influência da literatura, particularmente dos romances. Por isso, grande parte das resenhas de romances de até meados do Oitocentos mencionavam o perigo dos romances imorais para as mulheres. Temia-se que elas se deixassem levar pelas leituras e se desviassem do lugar que a sociedade lhes reservava e das funções que lhes eram impostas, como o cuidado com o lar e com os filhos (MÜLLER, 2012, p. 36; ABREU, 2003 , p. 282). Ao tentar tutelar as leituras femininas e ao desaconselhar certos romances às mulheres, muitos críticos e homens de letras do século XIX expressavam, na verdade, o receio diante da expansão da leitura e do acesso de novas categorias de leitores a um gênero novo e de popularidade crescente, o romance. As mulheres certamente não eram mais influenciáveis do que os homens como se alegava, mas talvez pudessem causar transformações na ordem social vigente se se deixassem influenciar, e esse parecia ser o temor de boa parte dos que queriam controlar suas leituras.

A Revista Popular, em textos de diferentes seções, apontava para a relevância do critério moral. Nos artigos destinados a recomendar ou desaconselhar leituras, sobretudo romances, ficava claro o emprego do critério moral e a preocupação com a formação da mulher leitora. 


\section{A LEITORA NA REVISTA POPULAR}

Como já mencionado no início deste artigo, a Revista Popular não era propriamente um periódico feminino, mas via nas mulheres parte de seu público. A publicação que a sucedeu na editora Garnier, o Jornal das Famílias, apresentava-se como um impresso mais diretamente voltado aos assuntos femininos (PINHEIRO, 2007, p. 52), enquanto a Revista Popular pretendia-se eclética e dirigida a um leitorado mais amplo. $\mathrm{O}$ texto que apresentava a revista em seu primeiro número, de 05 de janeiro de 1859, enfatizava o caráter abrangente da publicação:

Escrevemos de tudo para todos. Desde os tempos de Adão até o momento em que fallamos, desde as ruinas de Ninive até a recente Therezina [...], desde Veneza até a cidade do Lago Salgado [...] desde a toca do selvagem até aos paços faustosos do rei, desde a ostra, que se gera nas profundezas do oceano, até ao astro, que gyra pela immensidade dos céos, tudo o que abrange o entendimento humano é do nosso dominio (REVISTA POPULAR, 1859, p. 2).

A revista ambicionava comunicar-se com todos os públicos e abordar todos os assuntos, já que "tudo é do nosso domínio". E, ao escrever "de tudo para todos", pretendia atingir também as mulheres. Ao final desse texto de apresentação, dirigia-se particularmente às leitoras:

Agora duas palavras convosco, amaveis leitoras. Não vos escandaliseis, julgando descortez dirigirmo-nos em ultimo lugar á melhor metade do genero humano, como alguém disse. $\mathrm{O}$ que levamos dito entendese com o genero humano inteiro, em que 
tendes a devida parte [...]. Houve tempo em que a mulher só cultivava o coração, hoje cultiva tambem o espirito. Não haverá pois na Revista parte alguma que por qualquer principio vos esteja vedada, formosas filhas de Eva, mas haverá uma privativamente vossa, pelo que ficareis melhor aquinhoadas. (Assignai pois ou fazei assignar vossos pais, ou maridos, que é o mesmo.) Os trabalhos de agulha para as solteiras, a economia domestica para as casadas, e as - modas para todas - tudo isto é do vosso exclusivo dominio e nós lhe reservamos um cantinho (REVISTA POPULAR, 1859, p. 3-4).

A apregoada diversidade de temas - "tudo o que abrange o entendimento humano" - insinuava-se já no índice do primeiro tomo, no qual constam muitas e diferentes seções: Agricultura, Comércio e Indústria, Contos e Narrativas, Crítica e Análises, Crônica da Quinzena, Descrições, Economia Política, Emigração e Colonização, Esboços biográficos, Física, Higiene, Instrução e Educação, Geografia, Música, Poesia, Romances, Variedades. Além dessas diversificadas rubricas, cada número trazia, ainda, figurinos de moda desenhados na França, que eram, em geral, inseridos ao final da Crônica da Quinzena.

Ora, em uma publicação com tamanha variedade de assuntos, dizer às leitoras que nada lhes seria vedado, mas que o seu cantinho particular era o das modas e da economia doméstica soa como afirmar que elas poderiam ler sobre o que quisessem, fosse Geografia, Comércio ou Física, mas que aquele universo não era exatamente o delas. Era-lhes permitido (pelos homens responsáveis pela revista) espiar, passear por um terreno que não lhes era próprio, mas seu "exclusivo domínio" abarcava somente a moda, os trabalhos de agulha e a economia doméstica. O mesmo editor que acabara de 
proclamar que "tudo o que abrange o conhecimento humano é do nosso domínio" restringe o domínio das mulheres ("vosso exclusivo domínio"). Mesmo afirmando que as mulheres daquele tempo passavam a cultivar também o "espírito", e não apenas o "coração", o texto de apresentação da revista deixava entender que essa área não era propriamente voltada a elas, como bem observa Marcella dos Santos Abreu, em pesquisa de Mestrado sobra a Revista Popular:

Ao mencionar que, além do cultivo do coração, as mulheres preocupavam-se com o cultivo do espírito, os redatores procuraram abrandar um discurso comum no século XIX: a realização profissional e intelectual plena era alcançada somente pelos homens. $\mathrm{Na}$ verdade, reconheciam as preocupações do espírito como reservadas ao grupo masculino, dono das artes e da literatura. À mulher cabiam os interesses domésticos e a preocupação com a sua aparência (ABREU, 2008, p. 24).

Analisarei a seguir alguns dos textos veiculados na revista a fim de refletir sobre pensamentos e ideias a respeito da mulher que deles se depreendem.

\section{FERNANDES PINHEIRO: "EDUCAÇÃO E ILLUSTRAÇÃO"}

Ainda no primeiro tomo da revista, o Cônego Fernandes Pinheiro, em um artigo intitulado "Educação e illustração: estudo moral", discutia a educação feminina relacionando-a ao papel da mulher na educação dos filhos. Defendia que a mulher recebesse instrução, porém apenas para melhor capacitá-la para o exercício da função específica de educar os filhos: 
Assim, pois, as primeiras lições, e as que mais arraigadas nos ficão, recebemol-as nós no regaço materno. Principia felizmente a ser apreciado o importante papel, que assignou Deus á mulher, na grande obra da civilização humana. [...] Si é indubitavel a influencia que a mãi exerce sobre $\mathrm{O}$ futuro de seu filho, porque não se ha de preparar convenientemente a mulher para a sublime missão, que deve um dia exercer? (REVISTA POPULAR, 1859, p. 330-331).

As posições do cônego podem nos levar a crer, a princípio, que ele defendia a emancipação feminina, sobretudo quando, mais adiante, lamentava serem as mulheres "victimas de immensos preconceitos" (REVISTA POPULAR, 1859, p. 331). No entanto, seu texto estava bem longe de reivindicar uma atuação da mulher na sociedade que ultrapassasse os limites domésticos. Ao contrário, a instrução que ele recomendava tinha justamente o intuito de manter a mulher no lar:

Não somos utopista; não sonhamos a emancipação da mulher no sentido, que desejão alguns escriptores modernos. $\mathrm{O}$ theatro do sexo feminino é a familia, é o lar domestico o campo de suas operações. Sempre nos parecêrão aberrações a mulher guerreira, politica, agiota, \&c., mas quizeramos que se ampliasse a esphera dos seus conhecimentos, para que ella pudesse bem desempenhar a tarefa de educadora da mocidade (REVISTA POPULAR, 1859, p. 331).

O texto reforçava a ideia de que ao homem cabiam o mundo exterior, os "deveres sociais", e não a educação dos filhos:

A sciencia da educação, mais do que a nós lhes pertence. [...] Por mais desvelado que 
seja um pai, impossivel lhe seria incumbirse da educação de seus filhos. Forção-no os deveres sociais a longas ausencias, e a educação é um trabalho continuo, exige reiterados esforços (REVISTA POPULAR, 1859, p. 331-332).

$\mathrm{O}$ artigo de Fernandes Pinheiro seguia, portanto, o que parece ser a linha editorial da Revista Popular. Reafirmava, de certo modo, o posicionamento do texto que apresentava o primeiro número da publicação: nele, o editor deixava entender que a mulher podia ter acesso a todos os campos do conhecimento, mas o seu terreno próprio era o ambiente doméstico, as modas e costuras. Condizente com esse pensamento, Fernandes Pinheiro reivindicava que a mulher pudesse ser instruída e ilustrada, porém apenas como qualificação para educar os filhos, salientando que a tarefa "exige reiterados esforços". Porém, o lugar a ela reservado, seu "exclusivo domínio" continuava a ser o lar.

Ao sustentar que estudos mais sólidos dispensados às mulheres deveriam servir para "imprimir nova direcção a suas ideias, chamando-as á realidade da vida" (REVISTA POPULAR, 1859, p. 333), o cônego corroborava o pensamento - bastante recorrente entre os críticos que se expressavam sobre as leituras femininas - segundo o qual as mulheres seriam naturalmente mais voltadas à fantasia e ao devaneio. Chamá-las à realidade da vida, portanto, parece corresponder a chamá-las a seus deveres domésticos (entre os quais a educação dos filhos), e não a qualquer tipo de atuação fora das esferas do lar ou desligada do papel de mãe, cuja importância era exaltada pelo cônego. 


\section{LUIZ DE CASTRO: "A MULHER"}

Em um longo texto publicado no segundo tomo da revista, na edição de 05 de junho de 1859, Luiz de Castro reafirmava a concepção expressa por Fernandes Pinheiro, segundo a qual a educação recebida pela mulher deveria ter por objetivo aperfeiçoá-la para a função que a sociedade lhe destinava: os cuidados domésticos e a educação dos filhos. De maneira muito mais explícita e enfática que o cônego Fernandes Pinheiro, Castro insistia na submissão feminina como sendo desígnio divino e recomendava uma educação que reforçasse essa posição de subserviência e restrição ao lar:

Deus formou o macho e a femea, para serem um so todo, assignando a cada um o seu quinhão nos trabalhos d'esta existência terráquea. Ao homem assignou o labutar da vida, para isso o creou forte, audaz, empreendedor [...]; á mulher reservou o sanctuario domestico, os brandos cuidados da família, por isso a formou meiga, tímida, compassiva, amante (REVISTA POPULAR, 1859, p. 299).

A educação que aproveita a um sexo póde ser perniciosa ao outro. $\mathrm{O}$ rapaz tem de ser homem, cumpre não abater-lhe os brios, não esfriar a coragem [...]. Mas a menina tem de ser mulher, isto é, de viver sempre dependente e sujeita, acostumae-a pois bem cedo á dependencia e á sujeição (REVISTA POPULAR, 1859, p. 304).

Para Castro, a influência da mulher na sociedade se dava por meio da atuação dos homens que com ela conviviam: influindo nas decisões de seu marido e de seus filhos, a mulher influiria indiretamente na sociedade. Por isso, ela deveria ser educada com cuidado, recebendo apenas a instrução que lhe permitisse exercer bem o papel que lhe cabia: 
Se tal é a influencia da mulher, já se ve quanto cuidado é mister por em sua educação. Sim, educae, paes, educae as vossas filhas, mas a mulher é a casa - não o esqueçaes nunca (REVISTA POPULAR, 1859, p. 304).

A instrucção não pode ser para a mulher senão um objeto secundario, é um veneno salutar quando administrado em dose suficiente, mas mortal se for dado em excesso, porque então desvia-a da sua verdadeira missão, fal-a esquecer a casa, para que ella foi creada (REVISTA POPULAR, 1859, p. 307).

Toda forma de instrução ou ensinamento oferecido à mulher devia ter como objetivo mantê-la no lar e para o lar, "santuário" em que ela deveria exercer a sua "verdadeira missão". O articulista aconselhava que as meninas fossem educadas, de preferência, em casa:

Se a mulher é destinada á casa, é preciso que desde a infância se acostume a sentir as delicias da família. O gosto pela vida domestica não o pode ella adquirir, senão na casa paterna, a educação n'um collegio so em caso de extrema necessidade póde convir (REVISTA POPULAR, 1859, p. 306).

Ao que parece, a permanência das meninas em colégios não era mesmo praxe no Brasil oitocentista. Marisa Lajolo e Regina Zilberman, em A formação da leitura no Brasil (2001), transcrevem trechos de relatos de viajantes estrangeiros que por aqui passaram ao longo do Oitocentos que testemunham a precariedade da educação feminina naquele período. Os trechos abaixo, citados por Lajolo e Ziberman, foram escritos já no final do século XIX: 
As melhores famílias, não mandam absolutamente as filhas para colégios e devido a isso esta sociedade é, em geral, a menos educada e a mais selvagem que se pode encontrar (BINZER, 1991 [1881] apud LAJOLO; ZILBERMAN, 2001, p. 247).

Assim que [as moças] conseguem pronunciar algumas frases em francês e arranhar piano, está terminada a sua educação. Saem da escola e são moças, que os pais, com o máximo cuidado, preservam de qualquer contato com os homens (LAMBERG apud LAJOLO; ZILBERMAN, 2001, p. 247).

A jornalista Maria Amélia de Almeida Teles, na sua Breve história do feminismo no Brasil (1999), observa que, em meados do século XIX, o número de escolas para meninas no Rio de Janeiro era consideravelmente inferior ao das instituições de ensino para meninos. Além de menos numerosas, as escolas para meninas priorizavam a "preparação para as atividades do lar (trabalhos de agulha), em vez da instrução propriamente dita (escrita, leitura e contas)" (TELES, 1999, p. 27).

Luiz de Castro, dirigindo-se aos pais e nunca diretamente às mulheres, recomendava que a educação feminina fosse além dos trabalhos de agulha. Todavia, acreditava que a costura era a inclinação natural da mulher, o que mais facilmente ela era capaz de aprender; os outros ensinamentos deveriam se restringir a pinceladas de conhecimento, apenas para dar-lhe um verniz que a tornasse suficientemente ilustrada para as funções de esposa e mãe:

Paes, instrui vossas filhas, ensinae-lhes quanto póde ser util e agradavel: revelaelhes as maravilhas do universo; dae-lhes uma ideia do globo que habitão; referi- 
lhes os pontos cardeaes [...]; falae-lhes sobre tudo de Deus e dos destinos da humanidade; ensinae-lhes até um bocado de philosophia practica, que lhes inspire a resignação e o sofrimento, e, mostrandolhes as couzas segundo o seu justo valor, as não deixe ser victimas de males imaginários, de illusões e phantasias. Mas quanto menos livros, melhor (REVISTA POPULAR, 1859, p. 307).

É interessante notar que as lições de "philosophia practica" que o articulista recomendava tinham o propósito de fomentar a resignação e de frear a imaginação. Assim como Fernandes Pinheiro, que pretendia que os estudos chamassem a mulher "à realidade da vida", Castro também reproduzia a difundida imagem de mulher propensa à fantasia e à ilusão, tendências essas que, segundo ele, deveriam ser refreadas, sobretudo evitando o excesso de livros. Entre os livros a serem evitados estavam - e já era de se esperar - os romances, sobre os quais o articulista advertia explicitamente mais adiante: “O mal da maior parte das novellas está em pintarem os amantes como anjos, e os paes como verdugos. A donzella, que so por esta leitura conhecer o mundo, será sempre propensa a confiar-se dos primeiros, e arrecear-se dos segundos" (REVISTA POPULAR, 1859, p. 309).

A concepção utilitarista de literatura, segundo a qual as leituras podiam influenciar comportamentos, está fortemente presente no artigo. A ideia de que o romance era particularmente nocivo às mulheres fica bem evidente. $\mathrm{O}$ autor deixava entender que o romance levava à desobediência, pois fazia com que as moças confiassem em seus amantes e não em seus pais, desprezando, assim, a autoridade paterna. Castro ridicularizava as mulheres literatas, que se dedicavam aos estudos ou à escrita: 
Mas amor ás sciencias aridas ou abstractas - se descobrirdes nela o primeiro germen d'esta peçonha, suffocae-o depressa, antes que o mal não tenha cura. Abaixo d'uma mulher guerreira e varonil, não conheço, senão um homem mulherengo, e abaixo de uma mulher sabia e literata, nada. [...] Mulheres ha, que abandonão tudo que é proprio do seu sexo, para se entregarem á mania de escrever. Que lucrão com isso? Tornarem-se ridículas; renuncião á gloria de fazer a felicidade de seus maridos, criar e educar seus filhos, para comporem versos estropiados, ou novelas insulsas, em que revelão uma experiencia e conhecimento dos homens, o que lhes não faz muita honra (REVISTA POPULAR, 1859, p. 310).

Ao criticar as mulheres sábias ou literatas, Castro evocava e perpetuava um pensamento que vinha do século XVII. Lajolo e Zilberman (2001, p. 236) lembram que, na Europa seiscentista, as discussões sobre a educação da mulher ocorriam no momento em que a burguesia em ascensão precisava formar as pessoas que iriam atuar naquele modelo de sociedade. À mulher, cabia assumir as funções do lar e educar os filhos para aquela nova ordem social. Começou-se, então, a discutir a importância de instruí-la para esse papel.

O Traité de l'éducation des filles [Tratado sobre a educação das meninas], de Fénelon, surgido em 1687, tornouse um dos principais textos da época a respeito da educação feminina, vindo a influenciar pensadores posteriores. $\mathrm{O}$ autor sustentava que as mulheres tinham um papel civilizador como educadoras dos filhos e não podiam ser mantidas na ignorância. Defendia, pois, a educação das moças, mas reprovava as mulheres cientistas ou literatas. Condenava "a leitura de romances, de histórias fantasiosas, insistindo em uma educação realista e útil” (BASTOS, 2012, p. 150). Molière 
já havia problematizado, por meio do riso, a necessidade da educação feminina e os riscos dos excessos nas comédias Les précieuses ridicules [As preciosas ridículas], de 1658, e Les femmes savantes [As sabichonas], de 1671.

Lajolo e Zilberman ressaltam que, ainda no século XVII europeu, a educação feminina, embora "vital para consolidar a revolução burguesa" (2001, p. 238), era considerada perigosa se, por meio dos livros lidos, levasse a ideias de igualdade: "A instrução, concretizada em saber e ação, tornava-se perigosa e cabia advertir para a importância de fixarem-se limites e censurarem-se os excessos" (2001, p. 238).

Luiz de Castro parecia comungar dessa concepção burguesa de educação feminina, não diferindo muito do posicionamento já expresso na Revista Popular por Fernandes Pinheiro, nem do texto de apresentação do primeiro número do periódico. Seu artigo, constituído, pois, basicamente por conselhos dirigidos aos pais de moças sobre a educação delas, demonstrava alinhamento a tal visão e ao propósito da revista à medida que pregava que o acesso da mulher a diferentes ramos do saber deveria ocorrer, porém de maneira superficial e de forma a mantê-la em seu "cantinho" representado pelo lar e pelas ocupações que a sociedade reservava ao sexo feminino.

\section{CARLOTA FREDERICA: "CARTAS ESCRIPTAS DE BOTAFOGO”}

Como vimos, tanto o texto de Luiz de Castro quanto o do Cônego Fernandes Pinheiro tratavam de educação feminina dirigindo-se a homens, pais das moças, e excluindo da discussão as principais implicadas. Entretanto, a Revista Popular veiculou também alguns textos assinados por 
nomes femininos. O primeiro deles foi publicado já no primeiro tomo da revista, na edição de 05 de fevereiro de 1859. Apareceu sob forma de carta dirigida ao redator do periódico e assinada por uma suposta mocinha que se identificava como "Carlota a Frederico".

A jovem discorria sobre a temporada vivida junto de seus cinco primos homens durante as férias destes, no mês de janeiro daquele ano. Entre esses primos, seu preferido era Frederico, por quem estava apaixonada e com quem vivia momentos de um namoro adolescente.

A imagem que Carlota procurava construir de si no texto era a de uma jovem incauta, que parecia fazer questão de chamar a atenção para o seu desconhecimento a respeito de questões políticas e econômicas. Após revelar que, se pudesse um dia governar o país tomaria medidas que considerava divertidas (como conceder aos estudantes nove meses de férias por ano e promover "bailes a bordo das fragatas do estado"), ela lamentava que os governantes não pensassem como ela:

Mas parece que nem todos os estadistas pensão como eu; não fallão quando estão serios, senão em vias ferreas, estradas, canaes, pontes, bancos, colonisação, tratados, concordatas, progressos induistriaes, doutrinas economicas, etc., etc., cousas estas que devo confessa-lo, me parecem mui pouco divertidas (REVISTA POPULAR, 1859, p. 179).

Ainda firme no propósito de diminuir-se intelectualmente, a moça relatava que, quando seu pai recebia visitas de amigos, ela ouvia parte das conversas dos homens, que falavam sobre política, mas não conseguia compreender todos os assuntos. Pedia, então, que Frederico lhe explicasse sobre os temas para ela desconhecidos. Dessa forma, 
conseguia apreender "algumas migalhas" dos assuntos discutidos pelos homens:

Respirando pois esta atmosphera de atividade intelectual, recolho algumas migalhas, que germinão no meu pouco miolo, mas que não me inspirão o menor orgulho. Deus me livre de vir jámais a ser uma dessas literatas besuntadas de tabaco, destes bas-bleu impertinentes e rabugentas, que são a vergonha do nosso sexo, o desespero dos maridos, e o flagello da vida domestica!... (REVISTA POPULAR, 1859, p. 183).

Assim como Luiz de Castro no artigo aqui comentado (que seria publicado quatro meses após as "Cartas escriptas de Botafogo"), Carlota também associava a mulher literata ao flagelo do lar. Ao mostrar-se ingênua e dependente dos ensinamentos de Frederico para compreender os assuntos discutidos pelos homens, parecia corroborar a imagem de mulher de "pouco miolo" voltada à fantasia e despreparada para tudo o que ultrapassasse as fronteiras da vida doméstica. Seria ela a comprovação de discursos recorrentes sobre as mulheres, como aqueles propagados desde o século XVII, desde o Traité sur l'éducation des filles?

Em 19 de fevereiro de 1859, no número seguinte portanto, a Revista Popular publicou a segunda das "Cartas escriptas de Botafogo". Dessa vez, a assinatura não era mais "Carlota a Frederico", e sim "Carlota Frederica". A jovem continuava a falar de seus primos, especialmente de seu amado Frederico. Contava que lia impressos diversos ao lado do namorado e que tendia a apreciar os textos que ele considerava bons. Aqui é perceptível novamente a imagem da mulher como leitora ingênua, que necessitava da tutela masculina para julgar o que lia. Ela confessava um "ingenuo 
enthusiasmo pela sciencia" (REVISTA POPULAR, 1859, p. 244) e ensaiava reivindicar o acesso aos estudos superiores:

Por que não me havia eu de poder consagrar ao culto da sciencia, apezar do meu sexo! [...] Com que direito, caro redactor, se reservarião os homens o provilegio exclusivo dos estudos superiores, como monopolisárão tantas outras vantagens, em que nos negão o nosso quinhão? Consolemo-nos, porém, pobres mulheres que somos, já que nos deixárão, sem nol-o disputarem, o sacerdocio do amor. Aproveitemol-o pois!!... Demais, pela parte que me toca, não faço reclamações; uma pouca de felicidade repartida com Frederico me basta; uma choupana e o seu coração! (REVISTA POPULAR, 1859, 0. 244-245).

$\mathrm{O}$ que parecia ser um esboço de reivindicação de estudos superiores para mulheres revelava-se, entretanto, como uma resignação ao amor e ao universo doméstico.

$\mathrm{Na}$ sequência da carta, Carlota fazia algumas críticas carregadas de ironia, lançando indiretas a personalidades da época. Tais críticas eram disfarçadas de elogios, como se fossem observações inocentes de uma mocinha ingênua. Como exemplo, menciono a passagem em que ela enaltecia um escritor, cujo nome não citou, que havia publicado um artigo no jornal $\mathbf{O}$ Monarchista criticando o mau estado do cais de Botafogo. O autor afirmara que Plutão, se realmente existisse como rei dos mares, mandaria um ultimato àqueles que deveriam zelar pelo cais. Carlota o ironizou, afirmando que ele havia feito uma descoberta mitológica: em vez de reprová-lo explicitamente por ter-se equivocado ao chamar Plutão, e não Netuno, de rei dos mares, a suposta moça o aplaudiu com ironia, expondo-lhe o erro como se louvasse uma descoberta. Ao longo de sua segunda carta, Carlota teceu, 
ainda, outras alfinetadas e críticas permeadas de sarcasmo, que, à primeira vista, podiam parecer apenas o olhar ingênuo de uma jovem sem malícia.

As críticas demasiado irônicas da articulista e o esforço quase exagerado para acentuar a imagem de moça incauta que lia o mundo pelos olhos do primo permitem supor tratar-se de um pseudônimo. A mudança na assinatura da primeira para a segunda carta (de "Carlota a Frederico" para "Calota Frederica"), a omissão do sobrenome, a inexistência desse nome em dicionários ou compêndios bibliográficos da época e sua ausência na lista de colaboradores da Revista Popular fortalecem a hipótese. Resta conjecturar se por trás da "inocente" Carlota estaria um homem ou uma mulher. A quem interessaria transmitir uma imagem de mulher como um ser de "pouco miolo"? Observemos, a seguir, um outro texto supostamente de autoria feminina que pode auxiliar a reflexão sobre o assunto.

\section{IGNEZ D'HORTA: "GASTROSOPHIA"}

No tomo X da revista, em edição de abril de 1861, foi veiculado um texto com o curioso título de "Gastrosophia". Vinha assinado por D. Ignez D'Horta, nome que, pelo menos até aquele momento, não aparecera na lista dos colaboradores da revista.

Antes de abordar o assunto que era título de sua coluna ("Gastrosophia” apareceria outras vezes no periódico), D. Ignez d'Horta louvava os progressos da educação feminina:

Passados são felizmente os tempos em que preza como n'um circulo de ferro entre a agulha e a escumadeira, a mulher aprendia de letras apenas o bastante para fazer o rol da roupa suja, que entregava á 
lavadeira. Não assim hoje. No programma da educação feminil entrão todos os ramos dos conhecimentos humanos. [...] Graças a este melhoramento de systema, [...] póde já o sexo amável tomar parte em todas as conversas e até discussões sem limitação de assumptos e não só falar mas também escrever (REVISTA POPULAR, 1861, p. 223).

Para a articulista, o acesso a "todos os ramos dos conhecimentos humanos" abria às mulheres o caminho da emancipação, o que incluía poder escrever e publicar na imprensa. Assim, ela se apresentava como colaboradora da Revista Popular, que, até aquele momento, não contava com mulheres em sua redação:

Assim armada de todos os dotes do espirito marcha a melhor metade do genero humano a passos de gigante para a sua completa emancipação. Desceu de ha muito ja á arena da imprensa, e não ha ramo de litteratura em que ella não tenha dignissimas representantes. Só a Revista Popular não conta na sua redacção uma única litterata! É verdade que ha tempos apparecerão umas Cartas de Botafogo (por signal que erão excelentes) assignadas por um nome feminino, mas quanto a mim erão apocryphas. Não sei se quem as escrevia andava de saia, mas o habito não faz o monge, e eu era capaz de jurar que aquella pena manejava-a mão masculina. [...] Fosse porém o que fosse, d'esta vez pelo menos é certo que a Revista Popular vai ter também a sua collaboradora, e desde ja peço ao redactor das capas que inclua o meu nome na sua lista [...] (REVISTA POPULAR, 1861, p. 223-224). 
A princípio, parece tratar-se de uma mulher reivindicando espaço em um periódico que ainda não se abrira para as colunistas do sexo feminino, já presentes em outras publicações. No entanto, basta uma pesquisa mais acurada pelo nome de D. Ignez D’Horta em outras fontes para constatar que se tratava, na verdade, do pseudônimo de um homem, o assíduo colaborador da revista, Luiz de Castro, o mesmo que assinara o texto "A mulher", já comentado neste artigo. Ele aparece no Dicionário de Pseudónimos e Iniciais de Escritores Portugueses, de Adriano da Guerra Andrade (1999) e no respeitado Diccionario Bibliographico Portuguez, de Innocencio Francisco da Silva (1893). Segundo este último, Luiz Joaquim de Oliveira e Castro, português nascido no Porto, morreu no Rio de Janeiro, em 1888. Traduziu várias obras, foi jornalista, advogado, romancista, poeta e chegou a ser redator-chefe do Jornal do Commercio, de 1867 a 1888. Tanto Andrade (1999) quanto Silva (1893) mencionam "D. Ignez D'Horta" como um dos pseudônimos de Castro.

Seus escritos dispersos em periódicos foram reunidos após sua morte e publicados por seu filho, que também se chamava Luiz de Castro, no livro Obras do Dr. Luiz de Castro (1889). Boa parte dos textos escritos por ele para a Revista Popular estão na obra, entre eles os da coluna "Gastrosophia", confirmando, pois, que D. Ignez D'Horta era um pseudônimo seu.

O fato de "D. Ignez D'Horta", que agora sabemos tratar-se de Luiz de Castro, ter elogiado as "Cartas escriptas de Botafogo", da misteriosa Carlota Frederica, lançando suspeitas de que tivessem sido produzidas por "mão masculina", permite imaginar que possam ser de autoria do próprio Castro. Todavia, são apenas conjecturas que não se 
podem comprovar. As tais cartas não constam nas Obras do Dr. Luiz de Castro, o que não garante não serem dele, uma vez que seu filho, no prefácio, advertia não ter compilado a totalidade dos artigos escritos pelo pai. De qualquer forma, a possibilidade de que sejam dele ou de outro colaborador da revista não pode ser descartada.

Os artigos da coluna "Gastrosophia" continuaram no tomo XI da Revista Popular. O nome "D. Ignez D'Horta" apareceu na lista de colaboradores dos tomos XIII a XVI. A coluna trazia, a partir do tema "alimentação", curiosidades sobre países e costumes. E continha comentários sobre assuntos diversos. Fornecia pinceladas de conhecimentos gerais ligados à mesa e à gastronomia, no intuito de proporcionar uma certa ilustração à leitora.

É curioso que a publicação tenha preferido fingir dar vOZ às mulheres a efetivamente abrir espaço para elas. Em 1861, quando os artigos assinados pela suposta senhora D. Ignez D’Horta saíram nas páginas da Revista Popular, já havia no Brasil periódicos redigidos por mulheres. O Jornal das senhoras, fundado no Rio de Janeiro em 1852 por Joana Paula Manso de Noronha, circulara até 1855 e tratava de assuntos de interesse feminino, como, por exemplo, a reivindicação de "uma educação mais consistente para as meninas" (DUARTE, 2016). E mesmo alguns jornais dirigidos por homens já contavam com textos escritos por mulheres, como o Espelho das brasileiras, criado no Recife em 1831, no qual Nísia Floresta fez suas primeiras publicações (DUARTE, 2016). Ora, em meio a esse contexto, a Revista Popular pode ter pretendido mostrar que também estava sintonizada com as tendências da imprensa de seu tempo e também tinha vozes femininas entre seus colaboradores. Fazer crer que veiculava artigos produzidos por mulheres pode ter sido uma estratégia 
para atrair ou manter o leitorado feminino, que poderia se identificar com as supostas redatoras. Mas por que não dar voz a mulheres reais? Será que a Revista Popular não conseguia atrair senhoras interessadas em publicar em suas páginas? Se este era o problema, é possível que os responsáveis pela revista acreditassem que publicar artigos assinados por nomes femininos, dando a impressão de que haviam sido escritos por mulheres, pudesse encorajar leitoras a também produzirem textos para o periódico. De todo modo, o espaço que se abria para uma mulher na revista era, na verdade, fictício. A coluna "Gastrosophia" procurava transmitir uma certa ilustração às mulheres, porém por um ponto de vista masculino, ainda que forjando um discurso feminino.

Convém ressaltar que Luiz de Castro não foi o único homem a simular autoria feminina na Revista Popular. A prática repetiu-se na coluna "Fragmentos de um livro", que abordo a seguir.

\section{MARIA AMÁLIA: "FRAGMENTOS DE UM LIVRO”“}

No tomo XII da revista, iniciava-se a coluna "Fragmentos de um livro", cujos textos eram assinados por uma suposta moça chamada Maria Amália. Os artigos foram apresentados por Nuno Alvares Pereira e Sousa, colaborador frequente do periódico, assim como de outras publicações da época. Ele anunciou que entregaria ao público as "páginas íntimas de um coração de moça”:

4. Os textos de Maria Amália já foram por mim analisados no artigo "A leitura feminina sob tutela na imprensa oitocentista", publicado na revista Recorte (MÜLLER, 2015). 
Não sei se commetto uma indiscrição atirando essas paginas intimas de um coração de moça, ao publico, ou se melhor fizera conservando-as comigo. [...] Forãome ellas legadas ha muito tempo por uma alma piedosa e terna a quem eu amei com a pura devoção da amizade (REVISTA POPULAR, 1861, p. 271).

Nuno Sousa escrevia, geralmente, sobre literatura, exercendo, nos textos que publicava na Revista Popular, um papel de crítico literário. Maria Amália também abordava literatura em seus artigos, porém a partir do que poderia ser considerado o ponto de vista de uma jovem. Assim como o seu "amigo", ela também recomendava ou desaconselhava leituras baseando-se fortemente no critério da moralidade. Os escritos da moça destinavam-se a uma educação moral e literária das mulheres, particularmente das jovens solteiras. Em um dos textos publicados no tomo XVI, apesar de queixar-se de que os homens só falavam de banalidades com as moças, a articulista não condenava a conduta masculina; ao contrário, culpava as próprias mulheres:

Em grande parte somos nós as culpadas do pouco apreço que indubitavelmente lhes merecemos. Além do estudo preliminar que nos habilite a fazer um rol ou a marcar algumas peças de roupa, além de algumas lições de piano e canto, mais nada, a nada mais nos aplicamos, salvo a uma ou outra tintura do francez, tão sómente para comprehendermos os romances de George Sand e Balzac. Romances? E porque essas obras como a Familia, de Janet e Dargot, a Mulher no seculo XIX, de madame Ronieu, a Mulher catholica, do padre Ventura, porque esses livros, tão sublimes de bellezas, tão cheios de sentimentos, escriptos unicamente para mostrar-nos os verdadeiros dotes que 
deve possuir uma mulher, [...] dormem empoeirados nos livreiros, e só pullulão os romances, com suas côres phantasticas e mentirosas?! Eis ahi a fonte do desprezo que merecemos dos homens; receiosos da nossa nulidade em matérias de sentimento e instrucção, atirão-se ao debatido campo do galanteio e das modas! (REVISTA POPULAR, 1862, p. 98).

Assim como os textos analisados anteriormente, o artigo de Maria Amália também procurava destacar a precária educação feminina. Como Carlota Frederica, ela delineava uma imagem das moças em geral como pessoas de parca instrução e de "pouco miolo", despreparadas para compreender e participar das conversas dos homens. $\mathrm{O}$ fato de estes discutirem apenas futilidades com as mulheres não se devia, segundo a articulista, à mediocridade deles, mas à "nullidade em materias de sentimento e instrucção" da parte delas. Com a finalidade de amenizar o problema e de munir a leitora com os "verdadeiros dotes que deve possuir uma mulher", a jovem recomendava livros religiosos e manuais de conduta. E condenava, evidentemente, os romances, sobretudo os tão populares romances franceses, amplamente anunciados pelas livrarias da corte e frequentemente acusados de imoralidade pelos críticos (MÜLLER, 2012).

A insistência em culpabilizar as próprias mulheres pelas atitudes dos rapazes e pelas possíveis limitações da instrução que recebiam, chegando quase a ridicularizá-las, permite suspeitar que a assinatura de Maria Amália escondia uma autoria masculina. Por ter introduzido a coluna, apresentandose como o primeiro receptor dos textos da suposta moça, o crítico Nuno Alvares Pereira e Sousa pode ser cogitado como o possível nome por trás daquela “alma piedosa e terna”. Um pequeno deslize da jovem articulista fortalece essa hipótese. 
No terceiro de seus textos divulgados no último tomo da revista, Maria Amália aludia, elogiosamente aliás, ao livro Brasileiras célebres, que Joaquim Norberto de Souza e Silva acabara de publicar. Ora, o comentário de uma obra recém-lançada contradizia visivelmente o que afirmara Nuno Sousa ao introduzir os "Fragmentos de um livro": aquelas "páginas íntimas de um coração de moça" lhe haviam sido entregues há muito tempo.

O emprego de pseudônimos não era nada incomum no século XIX. José Leonardo do Nascimento (2008) acredita que eles serviam para camuflar o reduzido número de colaboradores da imprensa brasileira, escondendo, pois, dos leitores, que muito do que se veiculava nos jornais e revistas daquele tempo provinha da pena de um mesmo e relativamente diminuto grupo de autores. Entretanto, nos casos de Maria Amália, D. Ignez D’Horta e Carlota Frederica, a razão parece ir além dessa.

Ao denunciar a pouca instrução das moças e o desinteresse delas pelos livros de conduta que as ensinariam a adotar as posturas esperadas pela sociedade da época, Maria Amália colocava-se como exceção entre essas mesmas moças. Procurava mostrar-se como uma jovem em condições de repreender e alertar as demais; desenhava-se como alguém que, ao contrário de suas leitoras, já adquirira os tais "verdadeiros dotes que deve possuir uma mulher". Diferentemente de Carlota Frederica, delineada como um espécime de menina ingênua que descobria a necessidade de se deixar tutelar pelos homens, Maria Amália apresentava-se como modelo e guia de comportamento para as consumidoras da Revista Popular. Mas isso não quer dizer que pregasse a emancipação feminina: defendia a adequação da mulher ao que dela era esperado, a saber, algumas pinceladas de cultura 
e a submissão à moral e à família. A coluna "Fragmentos de um livro" demonstrava a intenção de "educar" suas leitoras, dizer às mulheres não somente como deveriam portar-se, mas também o que deveriam ler. Assim, é provável que o periódico e seus colaboradores acreditassem que as leitoras seriam mais eficientemente persuadidas por conselhos provindos de alguém de seu próprio sexo.

É interessante sublinhar que os textos voltados para o tema educação feminina mas assinados por homens não se dirigiam às mulheres. É o caso dos artigos de Fernandes Pinheiro e Luiz de Castro, que se destinavam aos pais, maridos e autoridades. As mulheres eram, pois, alijadas de uma discussão que lhes dizia respeito; era-lhes negada a voz em um assunto que deveria ser, antes de tudo, de seu interesse. Já os textos falsamente assinados por mulheres, estes sim, dirigiam-se diretamente às leitoras, podendo transmitir-lhes a falsa impressão de receberem conselhos vindos de uma pluma feminina na revista.

Quanto à visão de mundo expressa e às concepções a respeito da mulher e da educação que lhe deveria ser dispensada, os artigos veiculados sob pseudônimos femininos não diferiam em nada dos abertamente assinados por homens. Os textos de Carlota Frederica, D. Ignez D’Horta e Maria Amália constituíam-se como simulacros de discursos femininos que perpetuavam uma visão masculina sobre a mulher.

\section{CONSIDERAÇÕES FINAIS}

Propondo-se a escrever "de tudo para todos", a Revista Popular demonstrava incumbir-se de uma missão civilizatória. Pretendia educar seus leitores, atualizar-lhes os 
conhecimentos, conforme declarava o editor no texto de apresentação do periódico: "Havemos de acompanhar os progressos da humanidade. [...] Outr'ora quem aprendêra a ler e a escrever e as quatro operações tinha completado a sua educação. [...] Hoje não é assim. [...] É preciso que saiba um pouco de tudo" (REVISTA POPULAR, 1859, p. 1-2).

Esse propósito pedagógico de civilizar e ilustrar o leitor visava também o sexo feminino, porém de forma diferente. As mulheres eram um público que certamente a revista queria ter entre seus leitores. $\mathrm{O}$ texto de apresentação não deixava dúvidas quanto a isso: "Assignai pois ou fazei assignar vossos pais, ou maridos" (REVISTA POPULAR, 1859, p. 4). Todavia, educa-las não significava, para o periódico, abrir-lhes efetivamente as portas para "tudo o que abrange o entendimento humano", mas dar-lhes a conhecer um pouco desse universo, sem, contudo, permitir-lhes tomar posse dele. Ou seja, a revista propunha que a mulher adquirisse instrução, mas sem extrapolar os limites do que lhe era necessário para bem cuidar do lar e da família. Quando proclamava que as modas e a economia doméstica eram do "exclusivo domínio" da mulher, implicitamente a apagava ou a reduzia à condição de clandestina - no amplo cenário de conhecimento que pretendia oferecer a seus leitores ("tudo o que abrange o entendimento humano é do nosso domínio"). Ela podia apenas observar, do seu "cantinho", esse mundo de saberes e informações, sem, no entanto, obter a permissão para agir diretamente sobre ele.

Os textos voltados à educação feminina aqui analisados reproduziam a imagem, recorrente no século XIX ocidental, de mulher como criatura frágil e voltada à fantasia, devendo ser "chamada à realidade". Luiz de Castro, ainda mais incisiva e explicitamente do que Fernandes 
Pinheiro, reprovava a leitura de romances, reafirmando, assim, uma das ideias mais insistentemente repetidas entre os letrados oitocentistas: o perigo da influência dos romances sobre as mulheres. A mesma preocupação aparece nos textos de Maria Amália/Nuno Alvares Pereira e Sousa. Essa tentativa de controle das leituras femininas por parte de críticos, religiosos, médicos, censores e magistrados do Oitocentos deixava entrever, na verdade, o temor em relação às transformações sociais e familiares que poderiam ocorrer com o acesso crescente das mulheres à literatura. Era mister, portanto, limitar e tutelar suas leituras. ${ }^{5}$

Os textos falsamente atribuídos a mulheres reproduziam os mesmos pensamentos dos artigos explicitamente assinados por homens: a imagem da mulher como leitora ingênua que precisava da tutela masculina para compreender o mundo e para entender o que lia; a ridicularização da mulher literata; a resignação ao amor e ao universo doméstico.

A Revista Popular defendia a educação e a leitura femininas, porém com restrições. Sustentava que a mulher tivesse acesso aos vários ramos do conhecimento, mas que não se aprofundasse, que não fosse além de um verniz de cultura e ilustração. A instrução deveria servir para melhor formá-la para o lar, nunca para afastá-la dele. As "amáveis leitoras" deveriam ser capazes de olhar o mundo de longe, sempre mantendo-se em seu "cantinho".

\section{REFERENCIAS}

ABREU, Marcella dos Santos. Moda, teatro e nacionalismo nas crônicas da Revista Popular (1859-1862). (2008) Mestrado em Teoria e História Literária (Dissertação) - Instituto de Estudos da Linguagem,

5. Discorro mais detalhadamente sobre essas questões em minha tese de Doutorado, particularmente no capítulo 1 (MÜLLER, 2012). 
Universidade Estadual de Campinas, Campinas-SP.

ABREU, Márcia. Os caminhos dos livros. Campinas: Mercado de Letras, 2003.

ANDRADE, Adriano da Guerra. Dicionário de pseudónimos e iniciais de escritores portugueses. Lisboa: Biblioteca Nacional, 1999.

BASTOS, Maria Helena Camara. Da educação das meninas por Fénelon. História da educação. Porto Alegre, n. 36, v. 16, p. 147-188, jan.- abr. 2012.

CASTRO, Luiz Joaquim de Oliveira e. Obras do Dr. Luiz de Castro. Prefácio de Luiz de Castro, filho. Lisboa: Typographia da Companhia Nacional, 1889. Disponível em: https://www.literaturabrasileira.ufsc.br . Acesso em: 20 jun. 2021.

DONEGÁ, Ana Laura. Publicar ficção em meados do século XIX: um estudo das revistas femininas editadas pelos Irmãos Laemmert. (2013). Mestrado em Teoria e História Literária (Dissertação) - Instituto de Estudos da Linguagem, Universidade Estadual de Campinas, Campinas-SP.

DUARTE, Constância Lima. Imprensa feminina e feminista no Brasil. Século XIX. Belo Horizonte: Autêntica, 2016. Edição Kindle.

LAJOLO, Marisa; ZILBERMAN, Regina. A formação da leitura no Brasil. São Paulo: Ática, 2003.

LECLERC, Yvan. Crimes écrits. La littérature en procès au XIXe. siècle. Paris: Plon, 1991.

LIMA, Lilian Martins. Homens de letras e imprensa periódica no Rio de Janeiro (1836-1869). Em Tempo de Histórias. Brasília, n. 12, p. 86-105, 2008.

MARTINS, Ana Luíza; LUCA, Tânia Regina de. (orgs.). História da imprensa no Brasil. 2 ed. São Paulo: Contexto, 2013. Edição Kindle.

MOREIRA, Maria Eunice. Joaquim Norberto e a Revista Popular. Letras de hoje. Porto Alegre, v. 31, n. 4, p. 53-61, dez. 1996.

MÜLLER, Andréa Correa Paraiso. De romance imoral a obra-prima: trajetórias de Madame Bovary. Tese (Doutorado em Teoria e História Literária) - Instituto de Estudos da Linguagem, Universidade Estadual de Campinas, Campinas-SP, 2012.

MÜLLER, Andréa Correa Paraiso. A leitura feminina sob tutela na imprensa oitocentista. Recorte. Três Corações-MG, v.12, n. 1, p. 1-15, jan.-jun. 2015.

MÜLLER, Andréa Correa Paraiso. Divulgação e avaliação de romances em um periódico oitocentista. In: XV CONGRESSO INTERNACIONAL 
DA ABRALIC, 1, 2017. Anais eletrônicos. Rio de Janeiro: Universidade do Estado do Rio de Janeiro, p. 749-756.

NASCIMENTO, José Leonardo do. O primo Basílio na imprensa brasileira do século XIX. História e estética. São Paulo: Ed. UNESP, 2008.

PINHEIRO, Alexandra Santos. Para além da amenidade. O Jornal das Famílias (1863-1878) e sua rede de produção. 2007. Tese (Doutorado em Teoria e História Literária) - Instituto de Estudos da Linguagem, Universidade Estadual de Campinas. Campinas-SP, 2007.

REVISTA POPULAR: noticiosa, scientifica, industrial, historica, litteraria, artistica, biographica, anedoctica, musical. Rio de Janeiro: Garnier, 1859-1862. Disponível em: bndigital.bn.gov.br/acervodigital/ Acesso em: 15 set. 2021.

RONDELET, Antonin. De la moralité en art et en littérature. Revue Contemporaine. Paris, v. 67, t. 32, p. 531-554, 1863.

SILVA, Innocencio Francisco da. Diccionario bibliographico portuguez. Lisboa: Impr. Nacional, 1893.

SODRÉ, Nelson Werneck. História da imprensa no Brasil. 4 ed. Rio de Janeiro: Mauad, 1999.

TELES, Maria Amélia de Almeida. Breve história do feminismo no Brasil. São Paulo: Brasiliense, 1999. 


\section{CAPÍTULO 6}

\section{"TIL” - ÀS LEITORAS!}

Larissa de Cássia Antunes Ribeiro (UEPG/UNICENTRO- IRATI)

\section{A QUEM ESCREVE JOSÉ DE ALENCAR?}

José de Alencar é um autor bastante relevante na constituição do público do gênero romance no Brasil. Não apenas no aspecto de divulgação da cultura do país, mas na manutenção e no desenvolvimento de leitores e leitoras. Muitos questionamentos enfrentados pelos escritores até mesmo nos dias de hoje, tais como: "Como se colocar na cena literária?", "Como vender a sua produção?", "Como a obra representa o Brasil?" e "Qual é o lugar do gênero romance?" são apresentadas ao público por esse autor. Desse modo, abrese o diálogo com o leitor. Muitas dessas colocações de José de Alencar se encontram em artigos jornalísticos e aparecem, por vezes, em prefácios ou prólogos dos seus romances.

No prólogo de "O guarani", tem-se a voz autoral que se reporta diretamente a uma "prima" e a alerta: "Previnolhe que encontrará cenas que não são comuns atualmente; não as condene à primeira leitura, antes de ver as outras que a explicam" (ALENCAR, 1995, s/p.). Tal estratégia sugere a intimidade à interlocutora (a qual representa uma grande parcela da sociedade da época) e a própria concepção de 
sua escrita. Por mais que os comentários se apresentem com ironia, eles trazem o projeto literário desse autor que se consagrou desde o seu contexto de produção.

O gênero romance possui uma história bastante interessante, pois se configurou, a princípio, como produto feito para uma camada social tida como "inculta", devido às suas características formais: linguagem, temas e estratégias narrativas criadas para um público geral. Porém, aos poucos, vai ganhando posição na academia. Augusti (2008) salienta uma das principais barreiras enfrentadas para se constituir no século XIX:

Apartá-lo do público que originalmente lhe fora atribuído - o povo- e esquadrinhálo, submetendo-o a um conjunto de normas de composição e procedimentos de leitura, foram as tarefas que as instituições responsáveis pelo controle do exercício de produção e interpretação dos textos literários se impuseram no século XIX, tornando possível o amplo debate do qual resultou o gênero. (AUGUSTI, 2008, p. 394).

Devido a sua grande popularidade, observou-se o seu potencial em atingir um grande público e, inevitavelmente, houve um enorme interesse de outras camadas sociais, as quais trazem alterações significativas. Principalmente na Europa, mas também essas mudanças acompanham o ambiente literário brasileiro. Nesse contexto, Alencar se configura dentro de tais movimentos. Porém, é importante salientar que toda a sua obra traz o esforço pela conquista da popularidade e qualidade do romance no país. Ou seja, Alencar queria ser lido por mulheres e homens de todas as classes sociais. No entanto, sua pretensão veio acompanhada 
dessas preocupações com o desenvolvimento do gênero, no âmbito de sua produção.

A institucionalização do romance ocorre a partir do momento em que ele passa a ser estudado. No Colégio Dom Pedro II em 1860, Joaquim Fernandes Pinheiro realiza a obra didática "Curso Elementar da Literatura Nacional", onde se apresenta a verossimilhança em romances portugueses dos séculos VI e VII (AUGUSTI, 2008, p. 399). Isso ocorre juntamente à ascensão da burguesia e à configuração política. O gênero se presta à função persuasiva de educação moral e do trabalho. Augusti traz à tona Freire de Carvalho que aponta o romance como: “(...) um 'meio' extremamente eficaz de adesão dos leitores a condutas moralmente desejáveis levando-os a perceber os extravios, a que frequentes vezes as paixões o arrastam, tornando por esse modo amável a virtude, e odioso o vício" (AUGUSTI, 2008, p. 401). Desse modo, desenha-se a estética, a qual pretende emocionar para suplantar a falta de cunho reflexivo sobre o próprio indivíduo e o mundo que o cerca.

O interesse pedagógico não está desvinculado das questões políticas que o cercam. É o apelo ao trabalho, à honestidade e à religiosidade que passam a tomar conta dos romances dessa época. E nada mais eficaz do que o uso de metáforas e outros recursos poéticos para justificar e dar colorido às razões românticas: "Para cumprir tal designo, cabia no entanto fazer uso adequado da linguagem, observando a 'pureza da frase', exigência primeira da retórica, bem como escolher um 'estilo ameno', que não pusesse em risco a finalidade moralizadora do gênero" (AUGUSTI, 2008, p. 401).

Durante toda a sua carreira, José de Alencar apresenta tais temas, no entanto, eles são colocados sob diversas 
formas e nuances, o que chega até mesmo a tencioná-los a tal ponto que Candido (1964) segmenta o seu trabalho em três formatos, tal a diversidade dos conflitos que constituem as suas personagens. No texto "Os três Alencares" o teórico apresenta a primeira caracterização como a constituição do herói. Sendo que nas obras: "As minas de Prata", "O Gaúcho", "O Sertanejo" "(...) brotam como respostas ao desejo ideal de heroísmo e pureza a que se apegava, a fim de poder acreditar em si mesma, uma sociedade mal ajustada, em presa a lutas recentes de crescimento político" (CANDIDO, 1964, p. 220). Sob a ótica da representação simbólica, ele estabelece o modelo de comportamento pautado na sociedade brasileira e nas configurações regionalistas.

O segundo Alencar se constitui como o das mocinhas, no qual enfatiza a vida burguesa dos salões e preza sobretudo pelos bons costumes. Assim, em: "Diva", "Cinco minutos", "A Viuvinha" e "A Pata da Gazela" está: “(...) o criador de mulheres cândidas e de moços impecavelmente bons, que dançam aos olhos do leitor uma branda quadrilha, ao compasso do dever e da consciência, mais fortes que a paixão" (CANDIDO, 2000, p. 221-222). Os papéis sociais são revelados com muita ênfase e pontualidade, assim como as ordens e as configurações estruturais dessa sociedade.

Por fim, encontra-se o mais complexo dos três - o autor "dos adultos", onde o caráter perfeito é posto à prova a tal ponto que os sofrimentos apresentados se fazem diante de uma intensidade, cuja verossimilhança se realiza na dimensão muito mais aguda, pois tem-se o opressor e o oprimido em linha dupla. O leitor é chamado à reflexão dos limites estabelecidos pela sociedade desenhada nos enredos. Há, aqui, a demanda mais intrínseca pelo diálogo: 
Este Alencar, difuso pelos outros livros, se conte mais visivelmente em Senhora e, sobretudo, Lucíola, únicos livros em que a mulher e o homem se defrontam num plano de igualdade, dotados de peso específico e capazes daquele amadurecimento interior inexistente nos outros bonecos e bonecas. A Berta de Til, tem algo dessa densidade humana, (...) “. (CANDIDO, 1964, p. 222).

Til é um romance escrito em 1872, onde o autor traça retratos sobre a desigualdade social e a sensibilidade humana. A personagem principal é uma menina, a qual guarda em si uma imensa capacidade de controle de seus sentimentos e reorganiza os perigos e as adversidades que tocam a todos os indivíduos. Força e fragilidade são recondicionadas para que o equilíbrio social ocorra.

Em "Como e porque sou romancista" Alencar declara o seu encantamento pelo romance e reclama ${ }^{1}$ as condições

1. Ao cabo de vinte e dois anos de gleba na imprensa, achei afinal um editor, o Senhor B. Garnier, que espontaneamente ofereceu-me um contrato vantajoso em meados de 1870. O que lhe deve a minha coleção, ainda antes do contrato, terá visto nesta carta; depois, trouxe-me esta vantagem, que na concepção de um romance e na sua feitura, não me turva a mente a lembrança do tropeço material, que pode matar o livro, ou fazer dele uma larva. Deixe arrotarem os poetas mendicantes. O Magnus Apollo da poesia moderna, o deus da inspiração e pai das musas deste século, é essa entidade que se chama editor e o seu Parnaso uma livraria. Se outrora houvesse Homeros, Sófocles, Virgílios, Horácios e Dantes, sem tipografia nem impressor, é porque então escrevia-se nessa página imortal que se chama a tradição. O poeta cantava; e seus carmes se iam gravando no coração do povo. Todavia ainda para o que teve a fortuna de obter um editor, o bom livro é no Brasil e pôr muito tempo será para seu autor, um desastre financeiro. $\mathrm{O}$ cabedal de inteligência e trabalho que nele se emprega, daria em qualquer outra aplicação, lucro cêntuplo. Mas muita gente acredita que eu me estou cevando em ouro, produto de minhas obras. E, ninguém ousaria acreditá-lo, imputaram-me isso a crime, alguma cousa como sórdida cobiça. Que país é este onde forja-se uma falsidade, e para que? Para tornar odiosa e desprezível a riqueza honestamente ganha pelo mais nobre trabalho, o da inteligência! Dir-me-á que em toda a parte há dessa praga; sem dúvida, mas é praga; e não tem foros e respeitos de jornal, admitindo ao 
do romancista no país. No entanto, todas as suas obras reverenciam o Brasil, mas não deixam de expor as injustiças sociais. E, por mais que muitas vezes as personagens principais possam parecer intocáveis e até mesmo desumanas, elas são um grito esperançoso de justiça e progresso. Assim, o presente estudo tem como objetivo analisar a personagem Til e a sua representação para as leitoras de sua época. Para tanto haverá a reflexão a respeito de sua configuração frente às outras personagens, a representação feminina e a função social que ela desempenha, bem como afastamentos e aproximações com o público leitor.

\section{"TIL" - EM TOM SOCIAL}

A obra é bastante peculiar, pois ao mesmo tempo em que apresenta uma menina, como personagem principal, (o que levaria o leitor a supor que se trata de um romance feminino), traz um enredo bastante heroico, repleto de ações. Além disso, o narrador inicia com a bela apresentação do par romântico, mas surpreende o leitor com a ida e vinda da passagem temporal. Entre os mistérios do passado e as incongruências do presente. $\mathrm{O}$ cenário se alterna entre o interior e o exterior da fazenda instalada nos recônditos de São Paulo. No bojo familiar, há os enlaces e seus silenciamentos. As ações descritas nos ambientes externos, mais próximo à natureza, são impulsivas e reveladoras.

O romance é uma narrativa de vingança, que tem como eixo a figura de Besita, moça pobre, porém a mais bonita que havia nas vizinhanças de Santa Bárbara: "Quando ia à missa aos domingos e dias de guarda, todos se voltavam

grêmio da imprensa. Excedi-me além do que devia; o prazer da conversa... Maio de 1873. 
na rua para vê-la passar. Festa em que ela não aparecesse, perdia toda a graça; até os velhos achavam desenxabida e patuscada" (ALENCAR, 2012, p. 193). A moça é colocada dessa maneira no âmbito social e aparece de modo mais intrínseco entre dois personagens bastante diversos: Luis Galvão - um herdeiro de uma grande fazenda e Jão - órfão que foi criado junto com o jovem rico. Esse representava uma espécie de guardião obscuro: “Já em criança era robusto, valente, mas taciturno e sombrio; quando a molecada, que fazia roda ao senhor moço, o enquizilava, a ele Jão, ia-os sovando em regra, apesar de serem muitos e mais velhos (ALENCAR, 2012, p. 196).

Mesmo interessado em Besita, o rapaz fazendeiro, não quis desposá-la devido a situação financeira da pobre donzela:

Luís Galvão era magano e fagueiro, gostava de bulir com as raparigas e pregar peças aos caipiras. Daí resultavam constantes desavenças, em que Jão, para defender o moço, tinha necessidade de desancar os assaltantes, pagando em muitas ocasiões com a pele as aventuras galantes do jovem patrão (ALENCAR, 2012, p. 197).

Assim, por mais que houvesse um apreço entre os jovens, ela acaba se casando com Ribeiro, um negociante que a deixa no dia seguinte de seu casamento para viajar em prol de sua herança e somente retorna após dois anos: "Vendo-se rico de repente, não resistiu o moço à tentação de gozar dos prazeres com que o seduziam a cada instante as gabodices dos tropeiros marchantes (ALENCAR, 2012, p. 209). O fato revela a importância do casamento e a honra ao matrimônio para a época, o qual era tratado como negócio. O casamento de Besita se apresenta de maneira complexa: por um lado, tem-se a moça que, religiosamente, honra seu marido, mesmo sem amá-lo; por outro, há esse homem que 
parece desvalorizar a sua mulher, pois a deixa só, por questão de interesse econômico e, além disso, a trai. Tal contradição de posicionamento instala o clima de tensão pois propicia a sorte dos infortúnios.

Durante esse tempo de afastamento entre o casal, em uma determinada noite, um homem vai à casa de Besita. Zana, a criada, acredita que era patrão que chegava, permitindo a entrada e com ele, a esposa tem uma bela noite de núpcias. Somente no clarear do dia, ambas descobrem que era Luís Galvão e não Ribeiro, o amante ressurgido. Besita engravida e, escondida com o auxílio da negra, dá luz. Com o retorno do marido, a bela mãe acaba sendo assassinada. A criada enlouquece ao presenciar a cena e o bebê é salvo por Jão, o qual se tornara um profissional do crime. Berta, a criança, é adotada por Nhá-Tudinha, uma senhora trabalhadora e simples, mãe do jovem Miguel. Observa-se que há a representação da violação desse matrimônio e as consequências são devastadoras, ou seja, é essa lei social que é trazida para a discussão: casar sem amor realmente representa um laço sólido, perante os acontecimentos inesperados? A traição às cegas constitui a violação do casamento? É permitido matar por traição? É permitido trair por amor? E essa ação realmente pode ser considerada uma violação moral? A culpa por essa morte é mesmo de Zana? Sua loucura é uma consequência das leis sociais não cumpridas? Diante da complexidade desenhada, somos levados a refletir a respeito dessas dores, sofrimentos e injustiças, de acordo com a aproximação que descrevemos com as personagens.

A próxima sequência de ações traz a intensificação dos perigos e previsão de um novo crime, o que coloca o leitor, novamente na posição indagadora. Quinze anos depois do ocorrido, Ribeiro retorna a fim de se vingar de Luis Galvão. 
Com outra aparência e chamando-se Barroso, contrata Jão Fera para executar o crime. O capanga não o reconhece. Porém, a esperta Berta descobre a armação maligna e consegue impedir Jão. Em outra tentativa, com o apoio de escravos da Fazenda das Palmas, Ribeiro incendeia o canavial, justamente em noite de São João: "Noite de sortes consoladoras, dos folguedos ao relento, dos brincados misteriosos: Noite das ceias opíparas; dos roletes de cana, dos milhos assados e tantos outros regalos"2 (ALENCAR, 2012, p. 257). Ao tentar minimizar o fogo, Luis leva uma pancada na cabeça. Quando está para ser jogado às chamas, é salvo por Jão, que mata os responsáveis pelo incêndio, com exceção de Ribeiro.

Após, Jão Fera é preso em Campinas. Então, Ribeiro planeja matar Berta. Quando se aproxima dela, a qual cuidava da enlouquecida Zana, chega Jão (que fugira da prisão) e mata o vilão violentamente. Brás, sobrinho de Luis com problemas mentais, leva Berta para ver a cena. Ela foge horrorizada e Jão, sabendo que a moça o reprenderia, entrega-se à polícia. Jão foge mais uma vez da prisão e tenta falar com Berta. E essa implora para que ele diga toda a verdade a respeito de sua mãe. Então emocionada, Berta diz que ele é o seu verdadeiro pai, pois nunca a abandonara. Essa cena é bastante importante, pois os valores morais se deslocam ao converter o assassino em um pai protetor. A próxima cena dá acento a essa ressignificação.

Luis quer que Berta vá morar com ele, mas ela nega e pede que seu lugar seja ocupado por Miguel. Toda a família Galvão decide partir com novas pretensões de vida, mas a moça decide por ficar na fazenda para cuidar de Jão Fera, Zana

2. Observa-se o recurso da pontuação - os dois pontos no fim de cada frase enfatizam a comoção do narrador perante a estratégia criminosa. Bem como as afirmações que denotam a expectativa diante dos ocultos acontecimentos. 
e Brás. É importante salientar que todo o desenrolar dos fatos tem intensidade, junto à caracterização de cada personagem.

A Berta é compreendida por sua delicadeza encantadora, aliada a um movimento constante, o que lhe permite versatilidade dentro do ambiente pesado de disputas e vinganças: "Ela era pequena, esbelta, ligeira buliçosa, saltitava sobre a relva, gárrula e cintilante do prazer de pular e correr, saciando-se na delícia inefável de se difundir pela criação, e sentir-se flor no regaço daquela natureza luxuriante" (ALENCAR, 2012, p. 55). Além disso, a sua fusão com o ambiente natural é bastante significativa, ou seja, seus movimentos acompanham as paisagens e ela se faz protagonista no espaço imenso da natureza. Assim, presumese que a sua representação se alia às grandezas imensuráveis e até mesmo desconhecidas:

\footnotetext{
E assim é tudo nela; de contraste em contraste, mudando a cada instante, sua existência tem a constância da volubilidade. $\mathrm{Na}$ vaga flutuação dessa alma, como no seio da onda, se desenha o mundo que a cerca; a sombra apaga a luz; uma forma desvanece a outra; ela é a imagem de tudo menos de si própria (ALENCAR, 2012, p. 55).
}

Observa-se que a sua individualidade é diluída em uma promessa. Ela é um sujeito indeterminado, incompleto, pois está em constante devir. Por isso as imagens escolhidas para caracterizá-la são abstratas. A sombra ganha a conotação positiva do infinito, o qual guarda em si todos os trânsitos possíveis, tal como o mar que carrega o ir e vir das ondas. Comparada a Miguel, seu par romântico (cujo amor acaba por ser apenas uma vontade reprimida, por escolha da própria Berta), a sua delicadeza é descrita como superior à grandeza e compostura do moço amado: 
Ele, alto, ágil, de talhe robusto e bem conformado, calcando o chão sob $\mathrm{o}$ grosseiro soco da bota com a bizarria de um príncipe que pisa as ricas alfombras, seguia de perto a gentil companheira, que folgava pelo campo a volutear e fazendothe mil negaças, como a borboleta que zomba dos esforços inúteis da criança para colher (ALENCAR, 2012, p. 55).

A comparação com a borboleta, a qual seduz pela beleza, mas que exerce o movimento rápido e sutil que lhe garante a liberdade. E ele, comparado a criança, que apenas se encanta, mas desconhece as razões do encantamento, ou seja, ama mas não sabe o porquê e nem como irá conduzir seus sentimentos, acaba sendo vencido pela sublime borboleta que sabe voar, conhece os motivos de seus movimentos, controla seus desejos e suas paixões em nome de um bem maior: o equilíbrio social.

A heroína, então, supera o modelo da mocinha frágil e bonitinha, tal como é descrita Linda. Essa desde o nome é bastante característica. A sua beleza é tão primorosa como o frescor da natureza, também designada como pombinha, possui todos os atributos físicos que caracterizam a delicadeza regular de Berta, porém Linda, emocionalmente, tem um acento das virgens do mal do século - o vazio existencial que acarreta a melancolia: "Tinha a beleza de Linda um doce alumbre de melancolia, que não era tristeza, pois coavam-se através dos inefáveis contentamentos de sua alma; era sim matiz, que lhe aveludava a graça, e influía-lhe um mavioso enlevo" (ALENCAR, 2012, p. 55). Linda possui uma melancolia, que não chega à densidade de tristeza, pois sua concepção sobre si e seus sentimentos é bastante ingênua. Ela é leitora de Bernardin ${ }^{3}$, cujas obras foram reconhecidas

3. Em 1788, Jacques-Henri Bernardin de Saint-Pierre (de 1737 a 1814), publicou 
como símbolos da instrução moral e dos bons costumes para os jovens. Ao reportar a Miguel que lera "Cabana Indiana" e que admirava tal obra, o rapaz sorri de sua ingenuidade. Entretanto ela, bem-posicionada socialmente, zomba da condição financeira do pobre rapaz. Apresenta afeição por ele, mas sabe que a união entre ambos é impossível, por isso sonha com o enredo do amor desprovido de riquezas, descrito no livro que lera. Ela, de fato, destoa de Berta pois não se configura como uma agente social, capaz de comandar seu próprio futuro.

um romance bem curto, Paul et Virginie (Paulo e Virgínia), que narra a juventude de duas crianças criadas como irmão e irmã por suas mães à margem da sociedade, na ilha Maurício (na época uma colônia francesa conhecida como Île de France). O paraíso das crianças se transforma com a chegada da adolescência e o despertar da sensualidade contamina a afeição inocente. Virgínia é enviada à Europa por sua mãe, que busca mantê-la longe de Paulo. Quando ela retorna, seu navio é pego por uma tempestade ao longo da costa da ilha. Recusando-se a tirar a roupa na frente dos marinheiros para entrar na água, Virgínia prefere permanecer no navio afundando e se afoga, enquanto Paulo assiste. Ele morre de tristeza logo em seguida. De luto, as mães de Virgínia e Paulo morrem pouco depois. Esta "pastoral", um gênero literário popular na época, foi um sucesso sem precedentes. Traduzido para vários idiomas, parodiado e com frequência adaptado, durante o século XIX o livro foi considerado um clássico e muitas vezes recomendado para adolescentes, pois defende a virgindade e a modéstia a ponto de morrer. Leitores posteriores não têm se impressionado muito com a obra, que pelos padrões modernos parece enfadonha e sentimental. O romance, no entanto, mantém um importante lugar na história da literatura francesa, pois a violência das emoções dos personagens prenuncia a chegada do romantismo e do exotismo. Aqui apresentamos uma edição ilustrada de 1838. Ela começa com uma introdução sobre Saint-Pierre escrita por Charles-Augustin Sainte-Beuve (de 1804 a 1869), um historiador e crítico literário altamente influente. O texto de Paul et Virginie é seguido por algumas páginas de anotações e depois por La Chaumière Indienne (A cabana indiana). Esta segunda obra de Saint-Pierre, publicada em 1791, fala sobre um médico inglês que viaja pela Índia, onde encontra um pária, que, apesar das injustiças que sofre, parece ter descoberto os segredos de como viver uma vida feliz. A seção final do livro é composta por 37 páginas de notas ilustradas sobre a flora da ilha Maurício e da Índia, seguida por um índice dos artistas e gravadores do volume. Disponível em: $<<$ https://www.wdl.org/pt/item/14776/>>. Acesso: 26 mai. 2019. 
A mãe de Linda, em contrapartida, possui a astúcia gananciosa, mas não tem os encantos da filha:

À cabeceira, contra os costumes da terra ocupava-se a dona da casa, senhora de 38 anos, e não formosa, porém tão prendada de inata elegância, que seus traços e toda a sua pessoa tomava um particular realce. Se não tinha bonitos olhos, ninguém sabia olhar como ela; a boca sem primores de forma, enflorava-se com o sorriso inteligente e a palavra brilhante (ALENCAR, 2012, p. 82).

D. Ermelinda é filha de um capitalista de Campinas, colégio inglês e ares franceses. Escandalizava- com os costumes rudes do povo. Sua inteligência se destina à preservação da riqueza. A personagem não chega a ser má, nem boa, paira no meio termo, e entretém-se com os compromissos aristocráticos. E, com essa mesma conduta direciona a educação de Linda e o irmão Afonso. Ela também direciona as finanças de Luís Galvão, o qual tem um senso de justiça e caridade, mas é ofuscado por sua vaidade:

À direita estava o dono da casa, Luís Galvão, cujo aspecto franco e jovial granjeava simpatia ao primeiro acesso. Era um bonito homem, de fisionomia inteligente e regular estatura, que revelava em sua compostura digna a consciência do próprio mérito (ALENCAR, 2012, p. 83).

Miguel, Luís Galvão e Afonso se assemelham, pois simplesmente são conduzidos, não desempenham profundidade de ações. Suas consciências são rasas e por isso pairam na condição de tipos sociais cuja função é figurativa. Também, o decadente, Pai Quicé desempenha a função similar, porém ele representa a classe de escravos: "Entre eles se distinguia um inválido curvado como um arco de pipa, com a cabeça lisa como um quengo, e o queixo fino como 
uma faca desdentada; pelo que chamavam de pai Quicé. Era ele um dos favoritos de Berta, que todos os domingos lhe dava um vintém para fumo (ALENCAR, 2012, p. 189).

Vale destacar a mãe adotiva de Berta, a qual se coloca em função ativa. Ela desempenha o seu papel social, porém a sua consciência sobre o seu trabalho está muito mais para uma prática compulsiva do que para uma ação medida e racional: "Tinha essa mulherzinha baixa e rolha tal prurido da pele que não podia estar um momento sossegada. Por força que se havia de ocupar com alguma coisa; e para que lhe rendesse a tarefa, muitas vezes desfazia o que já estava pronto, a fim de ter o gosto de arranjar de novo" (ALENCAR, 2012, p. 152). No entanto, ela se dispõe a criar Berta e seu olhar social, se não é muito racionalizado, ao menos é comprometido e eficaz. As demais personagens, são mais profundas, pois apresentam conflitos e tensões que recobram à consciência de si e do mundo. E os apelos à racionalidade estão atrelados às ações de Berta.

\section{NO TOCANTE A TODAS AS CAMADAS SOCIAIS}

A condição de Berta é bastante peculiar: "enjeitada", segundo os parâmetros da sociedade. No entanto, tal designação passa a representar a sua ação reinante, em todos os ambientes em que frequenta: " $\mathrm{Na}$ casa, porém, onde se achava emprestada e por comiseração, era ela a verdadeira senhora, pois que os donos se faziam cativos seus e porfiavam em adivinhar-lhe as vontades para satisfazê-las" (ALENCAR, 2012, p. 135). Mas a menina, ciente de seu poder, não se prevalecia. Sentindo a sedução que exercia em torno de si, não abusava todavia, transformando-a em 
uma pequena tirania doméstica, à imitação de certas crianças dengosas (ALENCAR, 2012, p. 135). Ela detinha o seu olhar para os marginalizados, tanto com relação aos animais como com relação aos humanos. É importante apontar que há uma fusão das características humanas e animalescas.

Em uma situação em que Miguel caça uma cutia, para impressionar Berta, ela o reprende. Mas o rapaz faz uso de estratégias de caça para fazer-se apreciado por ela. Ele a tranquiliza, asseverando que a cutia era solteirinha e vivia só, por terem as raposas acabado com toda família, não tardando que lhe fizessem o mesmo a ela, pelo que era até um benefício retê-la cativa (ALENCAR, 2012, p. 168-169). Mas, não bastava tal argumento. Lançou a moça um compromisso social a ser cumprido, intimando Miguel a construir uma casinha para o animalzinho permanecer assegurado.

Outra situação também destacada no texto é o cuidado que ela destina a um burrinho ferido, o qual apresentava um aspecto repulsivo, mesmo assim, ela o socorre por todo o período necessário para a sua cura: “ (...) Não desanimou Berta, em cuja alma se produziam na maior efervescência os transportes dessas abnegações veementes, que são para certas naturezas uma necessidade irresistível de expansão" (ALENCAR, 2012, p. 127). A narração evidencia a prédisposição e o prazer que tinha na prática caridosa, como se ela tivesse a necessidade de agir dessa maneira.

Berta também apresenta o dom de domar e controlar os instintos perigosos. Há a passagem que a menina doma a cascavel simplesmente com a força de seu olhar: "Toda a força vital da boicininga se concentrava no olhar donde coava-lhe uma flama trépida, por entre as titilações da membrana sutil, que reveste a retina da serpente. Encadeada por entre o fio luminoso ao olhar cintilante de Berta” (ALENCAR, 2012, 
p. 225). Para que tal controle ocorresse, foi necessário que houvesse uma compreensão dessa natureza ameaçadora e isso ocorre através de uma atenção profunda e domínio de seus próprios sentimentos. Assim, compreende-se que o poder que ela exerce sobre outros somente ocorre devido ao equilíbrio que tem sobre si.

Em uma situação de vida ou morte, quando ela fugia dos perigos dos queixadas, Berta decide arriscar a sua própria vida para salvar a do escravo inválido:

O impulso de Berta foi precipitar-se para aquele refúgio e lutar de velocidade com os queixadas. Tinha confiança em suas forças e contava alçar a árvore antes das feras. Mas ao desferir a corrida, acudiu-lhe à mente $\mathrm{o}$ preto, que havia esquecido nas angústias daquele momento. Abandonar o velho decrépito à fúria dos animais não lhe sofria o coração, e contudo uma voz impiedosa, a vOz da conservação, lhe exprobrava o sacrifício inútil de sua existência. Há almas assim, que Deus apura no crisol da abnegação, e forma para se derramarem como a luz, o ar, o perfume (ALENCAR, 2012, p. 229-230).

Até mesmo o narrador se surpreende com a atitude de Berta, a qual vai se transformando a cada uma dessas cenas de abnegação. Certamente, um dos acontecimentos mais importantes é a alfabetização de Brás. Esse, tal como a cobra, representa o desagrado e o perigo eminente. Aos quinze anos, era analfabeto e dispunha de comportamentos maus e surtos recorrentes. Sua descrição se assemelha bastante a do réptil: "Era feio, e não só isso, porém mal amanhado e descomposto em seus gestos. Tinha um ar pasmo que embotava-lhe a fisionomia; e da pupila baça coava-se um olhar morno a divagar com expressão indiferente e parva". 
(ALENCAR, 2012, p. 83-84). Quase desumano era violento com a escrava da fazenda, jogou a cobra venenosa na cama de Linda e tentou enforcar Zana. E somente à Berta consegue desenvolver uma afeição, sendo que tal sentimento é capaz de tirá-lo dessa condição de selvageria.

O professor que havia tentado alfabetizá-lo era um antigo ferreiro, chamado Domingão, cujo nome já adianta a conotação de força e imposição: "Fiel às tradições da antiga profissão, entendia ele lá de si para si que um bom processo de ferrar bestas devia ser por força excelente método de ensinar a leitura e a tabuada: e fossem tirá-lo dessa ideia!" (ALENCAR, 2012, p. 163). E mais uma vez a força e a brutalidade são vencidas pela doçura e paciência da menina, a qual agia com cuidado e atenção. Tanto que o modo de desenvolver a linguagem escrita passa pela representação da própria menina. Como se nela estivessem todos os significados e significantes. A cena em que ela ganha a alcunha de "Til" demonstra a sua percepção e dedução lógica, a qual revela o tamanho apreço de Brás:

Nisso o Brás pulando como um boneco de engonço, passava a ponta do dedo mui de leve pelas sobrancelhas negras de Berta, por seus lábios finos, pela conchinha mimosa da orelha; e, apontando alternadamente para o til na carta do abecê, repinicava as risadas e os corcovos.(...) Associando-se à lembrança original do idiota, disse-lhe a menina, ajudando a palavra com mímica expressiva e apontando para a carta. - Eu sou til! (ALENCAR, 2012, p. 166).

Nesse momento, evidencia-se a ascensão mútua de ambas as personagens. Berta, por se colocar como a responsável pelo mundo das representações das palavras. E 
Brás, por sair de um ciclo de pensamentos aturdidos e iniciar o exercício para a clareza das ideias:

A camada profunda que soterrava o espírito do Brás, tinha um interstício por onde coava-se alguma chispa, que rareava as trevas carregadas dessa noite sem manhã. E por singular coincidência o primeiro balbucio da inteligência bota se dirigia a ela, como o primeiro vagido da criancinha no berço da chama pela mãe (ALENCAR, 2012, p. 166).

A partir desse renascimento, o menino inicia uma ressocialização, pois a cultura letrada é representada por relações as quais são comparadas a uma estrutura social. Cada letra representa uma pessoa, e essa se transforma ao contato de outra letra, pois passa a significar algo a mais. Assim Brás ressignifica a si mesmo e aos outros ao toque de Berta, a única que o tratou como um ser-humano, quando compreende as suas dificuldades e a maneira de interagir e transpor as agruras:

Assim em torno dela, que era o til, Berta foi engenhosamente agrupando todas as letras do alfabeto, com os nomes das pessoas e objetos que a cercavam. Pondo em jogo as broncas paixões do idiota, e colhendo os rudes germes de ideia que se formavam em seu bestunto, obteve ela afinal transformar a carta do abecê em uma família, em um mundo de uma existência enfezada dessa mísera criatura (ALENCAR, 2012, p. 168-169).

A influência de Berta ganha a conotação de milagre e remédio: "Dir-se-ia que se tinha operado a misteriosa transfusão d'alma do anjo na grosseira bestialidade do monstrengo" (ALENCAR, 2012, p. 169). Até mesmo com relação aos ataques epiléticos, os quais: “(...) não bastavam 
as forças de três homens possantes para sopear os ímpetos formidáveis, nem as mais energéticas aplicações para superar a crise violenta" (ALENCAR, 2012, p. 169); ela consegue apaziguar simplesmente com a sua força representativa. Basta a sua presença: “(...) o simples toque dos dedos de Berta ou sua fala maviosa, subjugava aquele furor, e aplacava logo aquela horrível convulsão" (ALENCAR, 2012, p. 169). São, portanto, as suas palavras (as significações que elas trazem) e seu toque (a representação física) os agentes da mudança.

O letramento só foi possível devido ao apoio do concreto para que o abstrato passasse a existir.

Através da relação que estabelece com Jão-fera, a menina passa à plural significação. Sua conotação vem acoplada à imagem da mãe e seu corpo se transforma em agente dúbio, entre menina-mulher. $\mathrm{Na}$ gruta quando ambos corriam risco de vida, talvez a morte os salvaria dos tormentos. No entanto, Jão resiste ao impulso de morte. O cenário do calor e do fogo, revelam os impulsos mais íntimos de uma fera desejante:

A terra abrasada pelo sol exalava o bafo incandescente de uma fornalha; e contudo sentia Jão Fera correr-lhe pela medula um calafrio. O contato do corpo gentil de Berta queimava-lhe o peito amplo; mas era a lava que ferve no meio dos píncaros gelados dos Andes (ALENCAR, 2012, p. 238).

Para esse homem ela significa a designação: mãefilha-amante. A composição significativa passa a conflito de consciência desse homem que ao optar por um amor sublime, ressignifica tudo e a si mesmo. Assim: de assassino passa a ser um salvador:

Naquele momento Jão Fera sofria suma de todos os sofrimentos que derramara em seu 
caminho; de todas as ânsias, que sua mão levantara. Tudo nesse homem, a dor como a alegria, a raiva como o amor, a gula como a embriaguez, revestia a natureza da fera, tinha fauce pra devorar, e garras que lhe dilaceravam o chão da alma, como a pata da suçuarana escarva a terra no arremessar do pulo (ALENCAR, 2012, p. 55).

É contudo, a fragilidade de Berta, que desperta o controle de toda a brutalidade de Jão Fera. A fragilidade convertida em delicadeza se transforma em força divina.

Outra personagem que merece a dedicação de Til é Zana. Essa, tem a consciência perturbada e não aceitação da morte de Besita, acompanhada de uma culpa irrepreensível, acabam por dominar a escrava. Por isso, a sua caracterização perpassa também a animalidade:

Acocorada a um canto, com o queixo sobre os cotovelos fincados ao peito cerrando a cara, descobria-se uma criatura humana, dobrada sobre sai a modo de trouxa. Era uma preta velha, coberta apenas de uma tanga de andrajos, e que resmoneava, batendo a cabeça com um movimento oscilatório semelhante ao calangro. De tempo em tempo desdobrava um dos braços descarnados, insinuava ligeiramente a mão pela espádua, e fazia menção de matar uma pulga que imaginava ter presa entre o polegar e o indicador (ALENCAR, 2012, p. 128).

A fuga da racionalidade representada pelas alucinações só pode ser vencida pela doçura das palavras, as quais fazem a louca recobrar a sua identidade. O diálogo que a menina estabelece com a negra ocorre por meio de uma cantiga a qual Berta decodificou entre os sons inarticulados de Zana: "Imagine-se que esforço de paciência e atenção não foram 
necessários à menina para decorar entre os sons ignotos e quase inarticulados, as palavras da cantiga, que ela dantes nunca ouvira" (ALENCAR, 2012, p. 133). A dedicação que ela dispunha aos marginalizados lhe dão as condições para reorganizar todo um cenário de injustiças.

\section{SENTIMENTOS RACIONALIZADOS OU ATITUDES COMOVENTES}

Com a revelação do passado e a morte de seu pai, Berta passa a ter o poder financeiro e o utiliza para unir Linda e Miguel. É importante mostrar os apontamentos que o narrador faz a respeito das diferenças de classe social e da predisposição de ambos em não abandonar as suas crenças e ideologias para unirem-se. Assim se desenha o conflito entre a fala do rapaz e a cultura aristocrática de Linda:

Esses cacoetes de caipira molestavam o tato delicado de Linda, a quem a educação esmerada, que recebera de sua mãe, dera a fina flor das maneirasse imprimira o tom da mais pura elegância. Quando Miguel a chamava de mecê ou enrolava diante dela a palha de um cigarro, o coração da menina apertava-se com agastura indescritível e ela sofria desgosto igual ao que lhe causaria uma nódoa caindo no mais bonito e faceiro de seus vestidos (ALENCAR, 2012, p. 267).

Ambos representam os grupos aos quais pertencem e se o sentimento os aproxima, os costumes os afastam. É necessário a ação de Berta para convencer Miguel a educarse para se casar com Linda. A inteligência de Berta se justifica pelo seu amor sublime: “(...) o cérebro feminino é uma roda movida pela manivela do coração" (ALENCAR, 
2012, p. 268). E como seu coração revela o bem social, é, com essa finalidade que ela organiza as suas reflexões. Ao renunciar a seu par amoroso e lhe proporcionar uma posição social, ela ocupa outra bastante diferente, a qual the garante outras satisfações, as quais não são compreendidas pelas razões humanas. Tanto que ela sofre de antemão, mas atinge satisfações não previstas: "O desânimo a invadira, acreditando estar só no mundo; mas já não o sentia, pois sua alma tinha ainda uma dedicação para ocupar, e sacrifícios em que derramasse os mananciais inexauríveis de sua bondade e ternura (ALENCAR, 2012, p. 266).

A relação que estabelece com Jão Fera é instrutiva, mas também apresenta o aspecto dúbio. Ao negar o reconhecimento de seu pai de origem e dar o título ao capanga ela inverte as posições de ambas. $O$ respeitado fazendeiro passa a ser enjeitado e o homem perigoso ganha a supremacia paterna. E, ainda, justifica a atitude e o compromisso da menina abnegada. O que dá a sua identidade representação e motivo de causa:

Meu pai és tu, que me recebeste dos braços de minha pobre mãe, com seu último suspiro. És tu, que a adoravas, como a uma santa; e quando ela deixou este mundo, não tiveste no coração outro sentimento mais, senão ódio a todos, menos a mim, que te lembrava ela. Oh; Eu compreendo agora, Jão, o que te fez mau!... Mas fiquei eu neste mundo em lugar dela para fazer-te bom! ... (ALENCAR, 2012, p. 318).

Observa-se que as más atitudes do capanga são redefinidas pelo olhar de Berta, porém o leitor sabe dos desejos ocultos de Jão e sabe que o olhar da menina, com relação a essa personagem, e, somente a essa, não é completo. Porém a função que o seu olhar desempenha se relaciona a outras 
tantas injustiças sociais: "Assim em compensação de tantas míseras crianças abandonadas por aqueles que lhes deram o ser, houve então um pai enjeitado" (ALENCAR, 2012, p. 320). Desse modo, as personagens são construtos sociais e a Berta representa a esperança para toda uma classe de sujeitos que foram desprovidos de cuidados e atenção. Por isso a sua atitude de permanência é imprescindível para o desfecho.

A sua presença garante que a justiça permaneça.

Olhares ansiosos seguiam Berta, que afastava-se lentamente de Miguel na direção de Palmas. Jão vergado sobre o cabo da enxada e agitado por veemente comoção, parecia despedir-se de si, para se precipitar aos pés da menina. Brás, cavado o semblante por violentas contorções, arrancava os cabelos da grenha ruiva, e mordia o beiço para não gritar. Zana estendia os braços hirtos, e no afã de alcançar Berta e apertá-la ao seio, rojava-se pela grama. (ALENCAR, 2012, p. 322).

A reação de cada personagem intensifica as ações de Berta, mas ao mesmo tempo, o medo pressentido revela que a menina não apaga todo o mal. A sombra permanece no cenário retratado: "Quando o sol escondeu-se além, na cúpula da floresta, Berta ergueu-se ao doce lume do crepúsculo, e com os olhos engolfados na primeira estrela, rezou a Ave-Maria, que repetiam ajoelhados a seus pés, o idiota, a louca e o facínora remido" (ALENCAR, 2012, p. 323). As designações negativas permanecem e podem ressurgir, caso o apelo divino de Berta titubeie. 


\section{CONSIDERAÇÕES FINAIS}

Ao ler o romance o leitor tem a primeira conotação de que a menina representa uma força angélica e é desprovida de qualquer paixão humana: "Como as flores que nascem nos despenhadeiros e algares, onde não penetram os esplendores da natureza, a alma de Berta fora criada para perfumar os abismos da miséria, que cavam nas almas, subvertidas pela desgraça. Era flor da caridade, alma sóror". (ALENCAR, 2012, p. 324). Porém, ao adentrar as representações, entendese que o que ela faz é tocar as personalidades a tal ponto que essas possam se perceber de maneira diversa. A personagem abala as significações e incita o leitor a refletir, a questionar as apresentações desse narrador que articula luz e sombras, suspenses e revelações.

Esse é um romance que traz os atributos femininos como fonte de mudanças significativas. Como fora mostrado, as forças brutas e os impulsos violentos são contrapostos às artimanhas da paciência e delicadeza, as quais se transformam em força intransponível. Se por um lado, a personagem é um ideal inatingível, ela provoca às mulheres a valorizarem a si mesma. Se nos reportarmos às leitoras ingênuas do século XIX, imagino que elas se reconheceriam nos detalhes dessa menina e sonhariam ao menos atingir um pouco do poder que ela exerce. Os leitores daquela época acompanhariam a narrativa repleta de ações heroicas e seriam questionados sobre os limites de suas próprias representações. E, por fim, os leitores de hoje são chamados à volubilidade dos papeis sociais. Til, é uma unidade representativa, um símbolo poético que dialoga com as pluralidades. 


\section{REFERENCIAS}

ALENCAR, José de. O Guarani. Apresentação e notas Ivan Cavalcanti Proença. 24 ed. Rio de Janeiro: Ediouro, 1995.

Til: Romance brasileiro. Apresentação e notas Ivan Teixeira; glossário Geraldo Gerson de Souza; ilustrações Sergio Kon. Cotia: Ateliê Editorial, 2012.

Como e porque sou romancista. Disponível em:

<http://www.dominiopublico.gov.br/download/texto/bv000311.pdf>. Acesso em: 25. abr. 2019.

AUGUSTI, Valéria. Do Gosto inculto à apreciação douta: a consagração do romance no Brasil do Oitocentos. In: ABREU, Márcia (org.). Trajetórias do romance: circulação, leitura e escrita nos séculos XVIII e XIX. Campinas: Mercado de Letras, 2008.

CANDIDO, Antonio. Os três Alencares. In CANDIDO, Antonio. Formação da Literatura Brasileira - Momentos Decisivos. São Paulo: Martins, 2000. 


\section{CAPÍTULO 7}

\section{ALÉMDASPÁGINASDE “OUERIDA”:} AS REPRESENTAÇÕES DE FEMINILIDADE PRESENTES NA "REVISTA QUERIDA" E A MEMÓRIA DE SUAS LEITORAS IRATIENSES DURANTE A DÉCADA DE 1960

\section{Cibeli Grochoski (UFPR)}

As revistas femininas que circulavam no Brasil no ano de 1960 traziam em suas páginas os chamados "assuntos femininos"; relendo estas páginas na atualidade é possível perceber quais eram os discursos predominantes na sociedade brasileira durante o período. De acordo com Carla Bassanezi (2006):

As páginas das revistas que tratavam de "assuntos femininos" nos levam ao encontro das ideias sobre a diferença sexual predominantes nessa sociedade. [...] traziam imagens femininas e masculinas, o modelo de família - branca, de classe média, nuclear, hierárquica, com papéis definidos -, regras de comportamento e opiniões sobre sexualidade, casamento, juventude, trabalho feminino e felicidade conjugal. Essas imagens, mais do que 
refletir um aparente consenso social sobre a moral e os bons costumes, promoviam os valores de classe, raça e gênero dominantes de sua época. Como conselheiras, fonte importante de informação e companheiras de lazer - a TV ainda era incipiente no país -, as revistas influenciavam a realidade das mulheres de classe média de seu tempo assim como sofreram influencias das mudanças sociais vividas - e algumas, também promovidas - por essas mulheres (BASSANEZI, 2006, p. 609).

A imprensa feminina é marcada pelos temas tradicionais que veicula, privilegiando assuntos perenes com pequenas conexões com a atualidade e atuando como influenciadora de suas leitoras. O periódico analisado nesta pesquisa é a revista feminina Querida.

Querida foi criada em 1953 no Rio de Janeiro, foi uma revista feminina que fez muito sucesso nas bancas brasileiras, editada pela Rio Gráfica Editora. Eram lançados dois periódicos por mês, quinzenal; em suas páginas a revista Querida trazia entretenimento e lazer para suas leitoras:

Querida tinha como público alvo mulheres adultas, letradas, de classe média das principais cidades do Brasil. O próprio título, "Querida", já poderia ser entendido como um protocolo de leitura, que designava seu público leitor. Querida pretendia ser amiga, companheira, confidente; leitura voltada especialmente às mulheres (SALERNO, 2009, p. 13).

Querida era uma revista conservadora e possuía um público formado por mulheres letradas, urbanas, pertencentes à classe média e heterossexuais. 
Os periódicos usados neste trabalho estão guardados no Centro de Documentação e Memória de Irati, CEDOC/I, da Universidade Estadual do Centro-Oeste - UNICENTRO. O acervo que foi doado em 2009 pela família do casal: Linda Garzuze Crissi (1916-2007) e Romeu Camargo Crissi (1910-2007).

Linda era uma leitora assídua da revista feminina Querida, ela colecionou todos os exemplares dos anos entre 1954 a 1967, guardou também outras revistas, livros, almanaques, convites de bailes etc. As revistas, relacionadas ao universo feminino, assinadas por Linda, demonstram o contínuo interesse que ela tinha em manter-se atualizada. Não por acaso, foi considerada uma das mulheres mais elegantes da sociedade iratiense de sua época ${ }^{1}$.

Após a leitura de Querida passei a interrogar sobre aqueles discursos presentes naquelas páginas amareladas pelo tempo, eram representações criadas sobre feminilidade e masculinidade, mas, trazidas como natural, verdades incontestáveis. Querida e outras revistas femininas formaram ou contribuíram para a formação da identidade de mulheres de toda uma geração, por isso, penso que os periódicos são uma fonte histórica incrível porque eles contam a história das nossas avós, nossas mães, das nossas ancestrais.

O objetivo desta pesquisa é analisar os discursos divulgados nos periódicos da revista Querida, durante a década de 1960, e detectar até que ponto eles formavam a subjetividade de suas leitoras. Nas páginas da revista, é possível analisar as relações de poder existentes nos discursos verbais e iconográficos, e entender como as leitoras de Querida se apropriavam dos discursos divulgados pela revista.

1. Disponível em: https://www3.unicentro.br/cedoci/wp-content/uploads/ sites/56/2018/10/Romeu-e-Linda-Crissi.pdf Acesso em 30/04/2021. 
Para atingir esses objetivos, além das análises dos periódicos, recorri à metodologia da história oral.

A utilização da fonte oral é pertinente neste estudo, pois analisamos a relação entre revista e leitora. Lendo a revista, surgiu a seguinte questão: será que as representações contidas nas páginas da revista eram um reflexo da sociedade naquele momento histórico? Para descobrir a resposta, entrevistar as leitoras foi imprescindível.

No começo, lamentei por não poder entrevistar Linda, mas encontrar as leitoras não foi difícil. Conversando, informalmente, com uma mulher, na faixa etária dos 60 aos 70 anos, descobri que ela era uma leitora e que conhecia outras, desta forma, tive contato com uma teia de contatos de mulheres, cada uma me indicava outras amigas, nem todas pertenciam ao grupo geracional que eu estava procurando.

A história oral é uma ótima fonte para o estudo sobre a história das mulheres, pois como aponta Michelle Perrot (1989), nos arquivos, as mulheres e outros sujeitos históricos foram silenciados. Com o intuito de compreender a relação entre a revista e as leitoras, utilizamos a entrevista temática, em conjunto com o método de trajetória de vida. As entrevistas foram feitas tendo por base um roteiro, mas também foram levantadas outras questões, durante as conversas, possibilitando traçar uma breve história de vida das entrevistadas. 


\section{CONSELHOS E REPRESENTAÇÕES DE MULHERES NAS PÁGINAS DE "OUERIDA"}

Conselhos eram comuns em textos da revista Querida, agindo como imprensa conselheira mostrava ensinamentos às leitoras, ajudando as mulheres a se adaptarem no mundo em que viviam, aconselhando-as a exercer "corretamente" sua "feminilidade" (PINSKY, 2014, p. 47). Muitos dos artigos da revista Querida abordavam assuntos que seriam de interesse de mulheres casadas, exibindo a representação de "rainha do lar", mãe e esposa. Não só em artigos, colunas ou contos encontramos essas representações, em anúncios publicitários é constante a presença de imagens concretizando a imagem atribuída ao feminino.

São muitas as páginas destinadas à publicidade na revista Querida, os anúncios, além de fornecerem o lucro à editora, produziam significados culturais. Nas propagandas, podemos analisar tanto o texto escrito como a iconografia, geralmente, um complementando o outro.

Muitas empresas utilizavam jornais e revistas para difundir propagandas de seus produtos. Em Querida predominavam anúncios de itens que estavam relacionados aos cuidados da casa, à higiene, à moda, à beleza, objetos que, supostamente, integram o universo feminino. Esses discursos publicitários contribuíam para construir e moldar os corpos femininos, de acordo com os padrões esperados pela sociedade. " $\mathrm{E}$ ao mesmo tempo, ensinar a esta mulher as normas adequadas socialmente, ou seja, como ela deveria ser, parecer e qual era seu papel nesse grupo" (SOARES; BARROS, 2014, p. 108). 
Segundo Silvia Sasaki (2010):

A mídia impressa sempre teve grande influência na construção das representações que permeiam o imaginário social. As possíveis manipulações de interesse veiculadas através da informação são reapropriadas e ressignificadas quando chegam ao leitor, abrindo-se também lacunas para as possíveis subjetividades. De um lado, a produção editorial, que discursa conceitos de civilidade, gostos, legitimando e instituindo padrões. De outro lado, a recepção dos leitores que, embora estruturados em conceitos pré-concebidos, também se encontram abertos aos novos ideais, transitando entre estratégias e práticas cotidianas (SASAKI, 2010, p. 01)

Os conteúdos da revista Querida reforçavam e reproduziam padrões sociais vigentes, durante os anos de 1960. Em suas páginas reproduziam normas e as legitimavam. Mas, como afirma Silvia Sasaki (2010), a recepção desses discursos pelos leitores pode ser distinta e subjetiva. Várias relações podem contribuir para moldar a subjetividade dos indivíduos e de seus modos de vida. Desta forma, os discursos podem se definir como "modos de sujeição, atravessado por valores morais, códigos, regras e estatutos” (RAMOS, 2005, p. 19).

Nas contribuições de Michel Foucault (1988), as constituições dos sujeitos estão ligadas entre o poder e o saber. Tais dispositivos criam modos de subjetivação e práticas disciplinares, percebemos que os discursos das revistas femininas se constituem num modo contemporâneo de subjetivação, utilizando-se de práticas disciplinares, pressupondo um suposto saber científico no qual estabelecem uma relação de poder sobre suas leitoras (SILVIA; STAFUZZA, 2013, p. 726). 
Portanto, Querida exercia poder, manifestava discursos que eram interiorizados pelas leitoras e contribuíam para a moldação de suas subjetividades. Porém, ao mesmo tempo em que a revista praticava o poder, também se submetia a ele, em razão de que ela era um produto que tinha como finalidade ser consumido.

Querida se definia como moderna, no entanto, apresentava modelos de mulheres e famílias tradicionais em suas edições. No decorrer da década de 1960, foi apresentando novas possibilidades para suas leitoras, embora continuasse com seus discursos conservadores. Compreende-se que essa ambiguidade é própria de períodos de transição, em que convivem o novo e o velho, uma vez que estava em gestação uma contracultura, que vai marcar os anos seguintes.

São muitas as propagandas em que é possível perceber a mistura entre tradicional e moderno. A seguir, temos o exemplo de um anúncio da marca "Ninho".
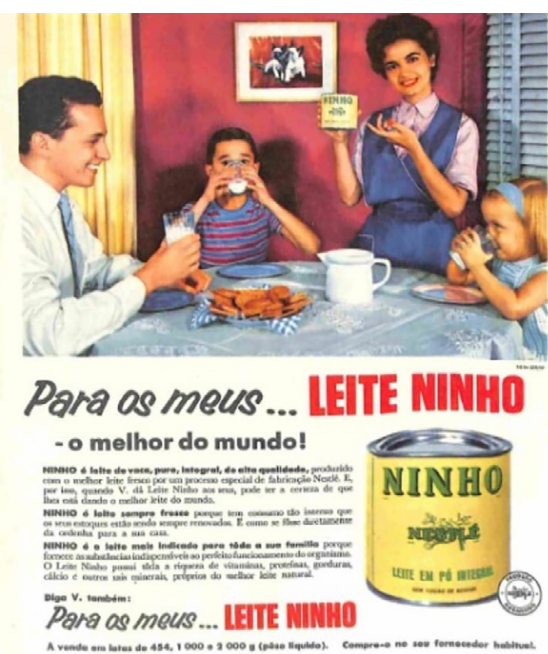

Fonte: Querida, no 135, janeiro de 1960. Acervo CEDOC, UNICENTRO - IRATI. 
$\mathrm{Na}$ ilustração, o leite em pó era apresentado como um produto moderno, integrando os bens de consumo que facilitavam a vida moderna. A comercialização de produtos industrializados tinha muito destaque no governo de Juscelino Kubistchek; durante os anos de seu mandato, ele "vai promover a abertura do mercado a empresas estrangeiras, oferecendo vantagens econômicas para aquelas que desejassem se estabelecer no Brasil" (QUADROS JUNIOR, 2001, p. 04). Essas mudanças, na economia, permaneceram com notoriedade nos anos que seguiram, e a sociedade ansiava em ser moderna.

Apesar de o produto moderno, o papel destinado à mulher, dentro de casa, continuava o mesmo, o tradicional. O discurso publicitário apelava para o amor e dedicação da mulher pela família, com o intuito de oferecer o melhor para eles. Aliás, ter uma família era projetado como o futuro de toda "boa moça", era o maior sonho e realização. De acordo com a historiadora Maria Paula Costa (2009):

O casamento oferecia acesso da mulher ao lar e à maternidade, as concepções de mulher moderna não rompiam com esse estigma. O homem aparecia como o "sexo forte" e a mulher como "frágil", aquela que sofria por amor e deveria se esforçar para cuidar bem do seu marido, sendo, (...) a sacerdotisa do templo culinário, responsável pela boa organização da casa, pela fidelidade do seu companheiro, estando atenta para as suas necessidades materiais, como roupas e acessórios, já que essas funções indicariam seus dotes de esposa e dona de casa (COSTA, 2009, p. 66).

Assim a "mulher moderna" não estava liberta das suas funções dentro do lar, continuava desempenhando o papel tradicional, agora ela se tornava uma mulher desdobrável. $\mathrm{Na}$ 
propaganda de "Ninho", é perceptível, tanto na descrição quanto na ilustração, o papel reservado à mulher, enquanto o casal de filhos e o marido estão sentados, ao redor da mesa, bebendo o leite, a mulher aparece feliz em servir a família, todos bem arrumados, o marido usando terno e gravata, remetendo a ideia de trabalho, casa organizada, e biscoitos, certamente, preparados pela esposa, acompanhados pelo leite que ela serviu.

Outra observação a ser feita é a representação da composição familiar, quase sempre a família moderna é formada por um homem (marido/pai), uma mulher (esposa/ mãe) e, no máximo, três filhos. Geralmente, as ilustrações trazem dois: um menino e uma menina. Esse é um dos aspectos da modernidade, a redução do número de filhos, as famílias planejadas se tornavam cada vez mais comum. Os casais utilizavam vários meios para controlar a natalidade, tais como: a tabelinha, camisinha, coito interrompido e, mais tarde, a pílula (PEDRO, 2003, p. 250).

Mas o que caracteriza a "mulher moderna"? Querida tinha como alvo leitor a mulher moderna, mas quem era ela?

Definir o que seria uma mulher moderna para a época mostrava-se um caminho árido, pois essa modernidade apresentava várias facetas: moderna consistiria em aderir e aceitar os novos comportamentos femininos no que se referia à liberação sexual antes do casamento? Ou mulher moderna seria aquela que não aceitava e questionava os papéis fixos de homens e mulheres na família e no trabalho? Ou simplesmente poderia ser considerada moderna a mulher que se identificasse e se incluísse a sociedade de consumo, usufruindo das novidades da indústria equipando seu lar e sua família com objetos que facilitassem sua vida, 
apoiando-se muito mais no ter do que numa modificação do ser? (COSTA, 2009, p. 71).

Um teste foi publicado, no ano de 1960, com o questionamento "Você é moderna ou antiquada?" Seguindo a linha de raciocínio do teste, a mulher moderna deveria ter respondido "sim" em usar batom e esmaltes todos os dias, escovar os dentes, no mínimo, duas vezes ao dia, e usar absorventes descartáveis ao invés de toalhas laváveis. Continua dizendo que, se respondeu pelo menos duas questões de forma negativa, então, não está aproveitando as facilidades da vida moderna, e o que ela tem para oferecer em questão de elegância e bem estar. "Deixar de ser antiquada para torna-se atraente e moderna, é simples questão de um pouquinho de fôrça de vontade" (QUERID $A$, set., n 152, 1960, p. 74).

Portanto, a "mulher moderna", nos parâmetros de Querida, não é a mulher independente, não modifica o seu ser e pensar, mas é a mulher que adquire produtos modernos; desta forma, a modernidade não está atrelada ao "ser" e sim ao "ter". Na revista, os corpos femininos eram representados sempre belos, a mulher recatada inserida no lar, ligada à figura de esposa e mãe.

Com todos os novos bens de consumo, a "rainha do lar" tinha a vida facilitada, havia mais tempo para outras atividades, na maioria das vezes voltadas ao lar, costura etc. Carla Bassanezi Pinsky (2012) cita que, até mesmo nas instituições de ensino, as moças eram ensinadas sobre a economia doméstica, e as revistas femininas, tal qual Querida, exibiam com frequência matérias relacionadas ao assunto. 


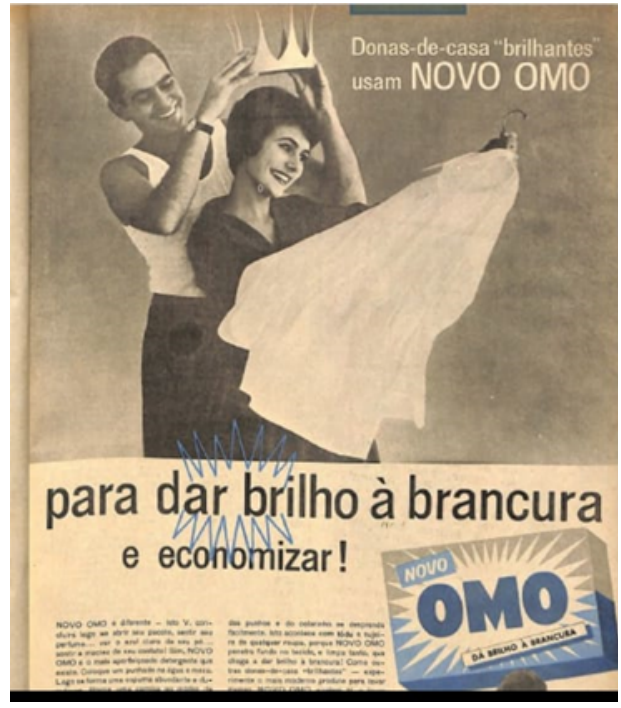

Fonte: Querida, n 183, janeiro de 1962. Acervo CEDOC, UNICENTRO - IRATI.

$\mathrm{Na}$ propaganda da marca OMO, podemos notar que a publicidade fazia uso da ideia sobre a "rainha do lar". A dona-de-casa "brilhante" e dedicada utilizava o produto para lavar as roupas do marido, reforçando papéis femininos de que somente as mulheres deveriam ser as responsáveis pelas tarefas domésticas. Para Carla Bassanezi Pinsky (2014):

A dona de casa não tem sequer poderes significativos nos bastidores domésticos. Como afirma Anne-Marie Dardigna, em seu estudo sobre a imprensa feminina, "o matriarcado da sombra não é mais do que a política do macho; o matriarcado onipresente"; a mulher dominada é persuadida de que é dominante, apesar de viver em um mundo em que as obrigações domésticas são dissimuladas e transformadas em manifestações de afeto. Assim, as mulheres deixam de reivindicar mais poder na sociedade. As esposas que cuidam da administração do lar exercem, 
na verdade, um papel de coadjuvantes do marido. A vida da dona de casa de classe média é uma vida "na sombra", "vivida por procuração", medíocre, sem criatividade, incapaz de grandes realizações. A ideia de que a mulher é a "rainha do lar" contribui para manter o mundo feminino separado do masculino pela mesma distância que separa o acessório do essencial. A verdadeira autoridade da família especialmente no que diz respeito às questões financeiras, é o homem, $\mathrm{O}$ provedor do lar. E a cada vez que a dona de casa quer ter acesso a um dinheiro, que só lhe pertence indiretamente, para fazer frente às despesas da casa ou pessoais, precisa dar satisfação e submeter-se ao humor e a condescendência do esposo. Assim, se mantém e reproduz o sentido de dominação/subordinação nas relações homem-mulher (PINSKY, 2014, p. 280).

Desta forma, a ilusão de "rainha do lar" mascarava mulheres submissas e dependentes de seus esposos, mesmo que, muitas vezes, de forma velada. Mas, em outras situações, a esposa vivia uma fantasia na qual ela é "persuadida que é dominante" por conta de administrar a economia doméstica, com o dinheiro do marido. Apesar de existirem "rainhas do lar" tristes, coexistiam as que se sentiam especiais em servir a família.

Porém, ao contrário do que Carla Bassanezi Pinsky (2014) afirmou quanto às donas de casa levarem uma vida medíocre e sem criatividade, Natalie Zemon Davis (1997) formou uma ideia diferente. Para ela, apesar de haver um discurso normatizador para o comportamento feminino, também existiam as possibilidades de criação nas margens da norma. 
De acordo com Natalie Zemon Davis (1997), embora as mulheres estivessem longe dos centros formais de aprendizagem e de instituições voltadas para a definição cultural, mesmo ocupando as margens das sociedades, elas extrapolavam os limites do lar, tinham criatividade e criavam novas experiências nos espaços. Assim, apesar de as estratégias da sociedade, as mulheres conseguiam criar táticas, sem seus cotidianos.

A revista conselheira, Querida, concedia instruções de como ser feminina e moderna em toda oportunidade que tinha, fosse em colunas sobre moda, culinária, automóveis ou horóscopo. Mas, de que forma as leitoras se apropriavam dessas representações normativas?

Entrevistar as leitoras da revista foi importante para buscar compreender se essas mulheres agiam de acordo com as representações e normas de conduta feitas pela revista, deste modo, indo, além das páginas da revista, ao encontro de suas leitoras.

\section{ALÉM DA MULHER DE PAPEL: AS LEITORAS IRATIENSES DE "QUERIDA"}

Na década de 1960, as mulheres estavam conquistando novos espaços e novas representações emergiam sobre o feminino; a revista Querida transitava por essas transformações. A revista é um produto cultural, ela vendia produtos e comportamentos que na década de 1960 estavam passando por grandes mudanças. A mulher deixa de ser apenas a "rainha do lar", agora ela é a "mulher moderna", que estuda e trabalha, mas a maior parte das páginas de Querida ainda tratam de temas voltados ao domínio do privado, da intimidade do lar, da família, e das áreas de comportamento 
feminino. Seguindo o que seria o destino "natural" de suas leitoras após o matrimônio. $\mathrm{O}$ discurso e as representações estão entrelaçados entre o moderno e o tradicional.

A revista tinha como objetivo ser comprada, por isso ela apresentava discursos conservadores já que os mesmos ainda permaneciam fortes na sociedade brasileira. Para compreender se esses discursos contribuíam para a formação das subjetividades das leitoras, foram entrevistadas três mulheres moradoras de Irati-PR que na década de 1960 liam revistas femininas, entre elas Querida. Para preservar suas identidades, os seus nomes foram substituídos pelos seus signos do zodíaco, desta forma temos as leitoras: Canceriana, Leonina e Sagitariana.

As revistas femininas eram uma forma popular de entretenimento entre as jovens, folheando os periódicos elas tinham acesso às novidades, a revista mantinha as leitoras atualizadas sobre as tendências da moda, música e cinema. Sagitariana (2019) conta que: "A gente trocava revistas, emprestava uma para a outra. A gente queria ficar por dentro da moda né o que usava, e tinha também aqueles cremes que a gente nem comprava nem tinha aqui na cidade, sabe a gente queria saber dessas coisas".

Muitos artigos presentes em Querida eram importados dos Estados Unidos, assim muitas novidades apresentadas pela revista não tinham para venda em Irati, mas mesmo assim as jovens iratienses gostavam de ler para ficarem atualizadas. Elas trocavam revistas, pegavam emprestadas com mães de amigas, folheavam em grupo ou sozinhas debruçadas sobre a cama, às vezes às escondidas.

Mesmo com tantas mudanças sociais e econômicas a educação da mulher continuava voltada para o lar. Como aponta Carla Bassanezi (2006), a família modelo dos Anos 
Dourados era constituída pelo "chefe da casa" que detinha a autoridade e o poder sobre a esposa, era também o responsável pelo sustento da família. "A mulher ideal era definida a partir dos papéis femininos tradicionais - ocupações domésticas e o cuidado dos filhos e do marido - e das características próprias da feminilidade, como instinto materno, pureza, resignação e doçura" (BASSANEZI, 2006, p. 608-609).

As entrevistadas Leonina e Canceriana, quando questionadas sobre a relação de esposa e marido dentro do lar, responderam: "Me lembro que diziam coitado voltou cansado, precisa descansar, não perturbe, a toalha está aqui, o sabão está aqui, a comida... Até hoje. Muita gente não dobra nem o guarda roupa" (LEONINA, 2018). A fala de Canceriana não foi diferente:

O pai trabalhava a maioria das mulheres não trabalhavam, então voltando lá, pela mulher não trabalhar e o homem trabalhar sempre assim tipo "vamos esperar o teu pai”, almoçávamos a família inteira junto, "quando teu pai chegar eu conto para ele", sabe aquele medo, a mulher tinha sempre muita é... Sustento tudo do marido então ela dava mais autoridade para ele também ou tirava a dela ela não queria ter a responsabilidade, não a responsabilidade, mas a palavra o discutir. (...). Então até isso. Sempre o homem um pouquinho mais acima da mulher mais, mas, não rebaixada, mas mais enfeite da casa do que... Não Sei se meu conceito é esse por que veja voltando mais, a minha vó, mãe do meu pai, trabalhava aqui na loja, sabe ela era... Trabalhava, criava filhos e... Sabe então eu acho que no fundo a mulher sempre foi mulher maravilha, sempre ela foi pode ver. Meu marido muito bom, muito bonzinho, mas se eu contar para você que ele deu alguma mamadeira ou 
trocou alguma fralda estou mentindo, então veja isso a quantos anos minhas crianças (CANCERIANA, 2018)

Em suas memórias as entrevistadas apontaram que as mulheres tinham a obrigação de cuidar do lar, dos filhos e do esposo, o serviço fora de casa para muitas mulheres não era possível ou necessário, pois o espaço público, o mundo dos negócios, era para os homens. Apesar da urbanização, industrialização e das mudanças econômicas e sociais que estavam ocorrendo no período, Canceriana estava destinada a ter a vida que a mãe e a sogra tiveram. Ela disse que era o homem que tinha a autoridade dentro do lar inclusive sobre a esposa, que a mulher era "mais um enfeite da casa". Ou seja, as mulheres continuavam vinculadas à esfera doméstica e às tarefas tradicionais femininas. Para as mulheres o domínio da casa era claramente o seu destino, como afirma Guacira Lopes Louro (2011):

As "mulheres deveriam ser mais educadas do que instruídas, ou seja, para elas a ênfase deveria recair sobre a formação moral, sobre a constituição do caráter, sendo suficientes, provavelmente, doses pequenas ou doses menores de instrução. $\mathrm{Na}$ opinião de muitos, não havia porque mobiliar a cabeça da mulher com informações ou conhecimentos, já que o seu destino primordial - como esposa e mãe - exigiria acima de tudo, uma moral sólida e bons princípios. Ela precisaria ser, em primeiro lugar, a mãe virtuosa, o pilar de sustentação do lar, e educadora das gerações do futuro (LOURO, 2011, p. 446).

A mulher deveria ter os conhecimentos básicos para educar os filhos. Assim como em muitos outros lugares do Brasil durante a década de 1960, em Irati havia dois colégios católicos que eram muito bem vistos pela população iratiense. 
O Colégio São Vicente de Paulo e o Colégio Nossa Senhora das Graças, um destinado aos meninos e outro às meninas.

O Colégio Nossa Senhor das Graças foi fundado em 1931 por freiras, a instituição também já funcionou como orfanato e, nas décadas de 1950 e 1960, ambas as instituições funcionaram como internato, pois muitos estudantes eram moradores da zona rural do município ou de outras regiões e não tinham condições de locomoção.

Estas instituições separavam seus alunos por gênero, por isso Canceriana, Leonina e Sagitariana estudaram na Nossa Senhora das Graças, escola destinada às moças e coordenada por feiras, já os rapazes frequentaram o Ginásio São Vicente, coordenado por padres. Nessas Escolas, além de Ensino Normal, os alunos eram educados para a fé cristã, e com ênfase em uma consciência patriótica.

As tarefas desses mestres e mestras não era contudo, exatamente as mesmas. Ler, escrever e contar, saber as quatro operações, mais a doutrina cristã, nisso consistiam os primeiros ensinamentos para ambos os sexos; mas logo algumas distinções apareciam: para os meninos, noções de geometria; para as meninas bordado e costura (LOURO, 2011, p. 444).

Meninas e meninos aprendiam coisas diferentes, de acordo com o gênero a que pertenciam e a função social reservada a elas e a eles na sociedade. A Economia Doméstica, por exemplo, era uma disciplina obrigatória apenas para o sexo feminino e a orientação metodológica teve em mira a "natureza da personalidade feminina e bem assim a missão da mulher dentro do lar"2. Esta disciplina ensinava sobre o

2. Ver mais em: https://www2.camara.leg.br/legin/fed/declei/1940-1949/ decreto-lei-4244-9-abril-1942-414155-publicacaooriginal-1-pe.html. Acesso em: 18/06/2020. 
"verdadeiro" papel da mulher, ensinando a cuidar e zelar do lar, do marido e dos filhos.

Canceriana (2018) conta que depois de casada somente ela realizava os serviços domésticos, o seu esposo nunca "ajudou", e: "nós meninas até na escola a gente tinha uma matéria sobre educação doméstica, então tinha caderno assim de como que limpa a casa, pano, paninho de limpeza, passar e varrer... aí meu Deus! você acredita que a freira ensinava" (CANCERIANA, 2018).

Leonina (2018) também relembrou desta disciplina e contou que aprendeu a cozinhar, costurar, bordar e a fazer enxoval na escola, enfim tudo que supostamente estaria ligado ao mundo feminino. A Economia Doméstica era um preparo para o lar, formadora de mães, esposas e donas de casa. Segundo Roseli Boschilia (2002), nas escolas as atividades masculinas estavam ligadas aos espaços externos enquanto que as atividades femininas ficavam restritas ao espaço interno nos quais aprendiam sobre música, bordado, pintura etc. "O exercício dessas atividades auxiliava na fixação de características consideradas tipicamente femininas, como o silêncio, a paciência, a perseverança e a delicadeza" (BOSCHILIA, 2002, p. 45).

Para ser considerada uma mulher para casar, as jovens precisavam apresentar boa conduta, serem recatadas, e cumprirem funções "supostamente essenciais a toda mulher, como cozinhar, lavar, limpar, costurar, educar e, em meio a todas essas atribuições, permanecer impecavelmente linda" (ALVAREZ, 2017, p. 45). As moças aprendiam essas "lições" na escola, na família e a revista Querida reforçava esse papel feminino, pois em suas páginas ela trazia inúmeras receitas e moldes de roupas para as leitoras copiarem, é importante ressaltar que no período roupas prontas não eram comuns. 
As revistas ensinavam a como ser e agir para conquistar um marido e como mantê-lo, para isso a mulher precisava ser exímia dona de casa e mãe. Esse pensamento era reafirmado pela família, desde cedo as meninas aprendiam com a mãe a como "ser mulher", esposa-mãe-dona de casa, o tema maternidade estava sempre presente na revista Querida.

As marcas utilizavam o discurso de serem modernos, mas havia uma oscilação entre o moderno e o tradicional:

O casamento oferecia acesso da mulher ao lar e à maternidade, as concepções de mulher moderna não rompiam com esse estigma. O homem aparecia como o "sexo forte" e a mulher como "frágil", aquela que sofria por amor e deveria se esforçar para cuidar bem do seu marido, sendo, (...) a sacerdotisa do templo culinário, responsável pela boa organização da casa, pela fidelidade do seu companheiro, estando atenta para as suas necessidades materiais, como roupas e acessórios, já que essas funções indicariam seus dotes de esposa e dona de casa (COSTA, 2009, p. 189).

A maternidade era um dos assuntos mais recorrentes na revista Querida, os filhos eram uma certeza após o casamento, as moças casadoiras sonhavam com esse futuro. A mulher idealizava a felicidade depositando suas esperanças onde a tradição lhe ensinou a deposita-las: no Matrimônio, no lar e na maternidade. Ao casar-se a mulher "recebia um pacote de tarefas e uma multiplicidade de funções que haviam sido incutidas às mulheres desde a infância: uma preparação necessária que a sociedade patriarcal, (...) desenvolvera muito bem na consciência feminina" (COSTA, 2009, p. 189).

"Ficar pra titia" era um medo entre as jovens, motivo de zombaria, as mulheres solteiras com mais de vinte e cinco anos recebiam o rótulo de "solteironas". Essa situação era um 
estigma, uma situação social indesejável. A mulher solteira era vista como "incompleta", nem esposa nem mãe.

Canceriana (2018) disse que se casou tarde para a "sua" época, com vinte e seis anos, neste período era normal o casamento após o término do magistério, antes dos vinte anos de idade. De acordo com Leonina (2018):

Casavam muito cedo com 17, 18 anos, imagine é muito cedo o que você sabe com 18 anos e casar, cuidar de casa logo engravidavam né. Então elas ficavam iam se acomodando né. "Não, fique com ele porque ele é bom da o que comer, olhe a casa, olhe isso...". E hoje em dia não, hoje você não aceita você sabe né, isso não aconselha a ninguém, não deu certo... (PINSKY, 2014, p. 12).

A entrevistada destacou que o divórcio não era bem visto socialmente. De acordo com Carla Bassanezi Pinsky (2014) no Brasil o desquite ganha força a partir dos anos de 1950, e somente no ano de 1977 o divórcio vira lei:

Até então, o único marco legal da separação de um casal é o desquite, que impossibilita um segundo casamento pelas leis brasileiras. A oposição à legalização do divórcio vem da Igreja Católica, de grupos conservadores organizados, mas também de grande parte da opinião pública. Assim, apesar das tentativas dos divorcistas, nessa época prevalece o conservadorismo que alega defender a sociedade contra "a desorganização da família", "o amor livre" e "a introdução do comunismo" (PINSKY, 2014, p. 12).

Leonina (2018) disse que as jovens se casavam muito cedo e após o matrimônio a maioria delas vivia em função da família e do lar. Na década de 1960 existia o desquite, mas 
ser uma mulher desquitada era visto com maus olhos pela sociedade, sobre esse assunto a entrevistada continua:

A questão era a seguinte você se separar de um marido, dissolver um casamento era culpa da mulher, que ela não agradou, ele teve que procurar fora de casa, né. Então nesse ponto que ficava muito velado, elas não queriam que o pai soubesse por que vai incomodar, dai ela levava a vida inteira marido traia, mas levava porque primeiro muitas mulheres não trabalhavam fora, a grande maioria, total de dependência do marido, filhos né, então se anulava. Muitas mulheres se anulavam, casavam e ficavam como em prisão, nunca mais iam a baile nenhum, a gente via sair só com o marido, ele ainda tinha mais liberdade. Alguns, não geral, mas o que a gente via era que elas suportavam muita traição do marido, sabe? $\mathrm{E}$ você não podia se separar porque você jurou que ia ficar... (PINSKY, 2014, p. 12).

Toda ameaça ao casamento era lavo de críticas, falar em divórcio era considerado imoral, "a pior chaga da sociedade". O Código Civil brasileiro de 1916 mantinha o matrimônio indissolúvel e a mulher era considerada incapaz de exercer certos atos e tinha uma posição de dependência e inferioridade em relação ao esposo, nem mesmo trabalhar a mulher não poderia sem a permissão do marido (DEL PRIORE, 2005, p. 259). Por isso quando Leonina (2018) afirmou que muitas mulheres ficavam "presas" ao casamento, mesmo esse sendo infeliz, pois elas não tinham escolha, Canceriana (2018) disse que mulher desquitada era mal falada, além disso, os filhos também ficavam "manchados" socialmente:

Assim, tipo mulher separada era assim... Mãe solteira era mais respeitada do que separada, não era muito bem vista sabe. 
Só sei que, por exemplo, as meninas, a gente não, não... Era da época não que a minha mãe achava isso, era, por exemplo, menina filha de... Se você fosse filha de mãe separada não era muito bom eu andar com você porque a tua mãe é separada, então veja que coisa né. $\mathrm{E}$ era assim, não tão abertamente, mas nas entrelinhas, sabe. Se você fosse filha de mulher separada não era boa companhia. Muitas ficavam casadas por causa dos filhos... (CANCERIANA, 2018).

Muitos motivos mantinham as mulheres ao seu casamento entre eles a falta de opções ligadas ao financeiro já que a maioria das mulheres não trabalhava, assim tendo total dependência financeira do marido. E outro motivo era a moral social dos filhos, pois como Canceriana (2018) menciona, as mães não deixavam as "moças de família" ser amigas de pessoas pertencentes a lares desfeitos, a dissolução do matrimônio era considerada um pecado. $\mathrm{O}$ homem não tinha a reputação ferida pelo desquite, ele era considerado a "vitima" na maioria das vezes. É interessante notar que Canceriana justifica o julgamento da mãe relacionando à época e afirma que hoje ela não pensaria da mesma forma porque os tempos são outros, ou seja, Querida é um espelho de seu tempo, ela reflete representações e concepções sociais vigentes na década de 1960.

Em 1968 Querida apresentava a seguinte orientação para as leitoras: "A mulher divorciada ou desquitada, por causa dos preconceitos, tem que enfrentar sérias consequências. Ao lado das complicações morais, alinham-se contra ela todos os problemas de caráter financeiro e material" (QUERIDA, $\left.1968, \mathrm{~N}^{\mathrm{O}} 335\right)$. Sempre que a revista tocava no assunto de separação, desquite e divórcio era desencorajando as leitoras a tomarem essa decisão, da mesma forma que Leonina citou 
que as mulheres aconselhavam as amigas, mandando a esposa pensar no lar e na família.

O trabalho feminino remunerado não era a regra, o papel tradicional de mulher estava muito presente na sociedade da década de 1960, entretanto algumas famílias começaram a investir na formação acadêmica de suas filhas. As entrevistadas Canceriana e Leonina, após terminarem o magistério, se mudaram para Curitiba para estudar Letras na PUC. Canceriana exerceu a profissão somente até o casamento, já que depois disso ficou atarefada com assuntos domésticos, e:

Minha sogra (risos) era um amor, mas olha o ditado dela, veja bem isso era a cabeça dela, eu escutava né, eu não podia querer discutir, mas ela dizia assim com todas as letras: "Gato e mulher em casa; Homem e cachorro na rua" esse era o pensamento que ela foi criada e assim ela criou os filhos dela sabe então pode ver... Os maridos não enxugavam louça, não faziam nada, não participavam (CANCERIANA, 2018).

A condição de dona de casa foi imposta a ela, o velho discurso que os espaços públicos eram destinados aos homens e o privado à mulher ainda estava presente na década de 1960 e 1970 nas famílias tradicionais iratienses. Canceriana acabou herdando o negócio da família de seu pai e hoje administra o comércio, sua sogra discordava desta possibilidade.

A sogra de Canceriana cresceu ouvindo esses discursos nas rodas de conversa, entre familiares, na Igreja, na escola, nos romances, nas mídias e, como aponta a entrevistada, ela criou os filhos da mesma forma, relacionando o lar e todos os seus cuidados à mulher. Tanto que o marido de Canceriana não participa das tarefas domésticas e nem 
contribuiu com o cuidado dos filhos como trocar fralda e preparar a mamadeira, por exemplo.

Das três mulheres entrevistadas, apenas Leonina seguiu os estudos, se tornando mestre em Letras, e construindo uma carreira universitária. Segundo a historiadora Ana Paula Vosne Martins (1992) os planos individuais das mulheres dependiam da vontade da família, algumas mulheres se formavam e se estabeleciam no mercado de trabalho se tornando independentes financeiramente. Entretanto, outras valorizavam o modelo de feminilidade centrado nas prendas domésticas, iam para a faculdade deixando para trás um noivo a quem elas retornariam "doutoras"; muitas nunca exerceram a profissão, apenas tinham um diploma. Como afirma Ana Paula Vosne Martins, elas carregavam o canudo em uma mão e a aliança em outra, dando mais importância para a última.

A revista Querida sempre apresentava matérias sobre noivado e casamento, principalmente no mês de maio, conhecido como mês das noivas; não só a revista publicava matérias sobre o assunto, mas também as marcas utilizavam a data para vincular seus produtos ao casamento.

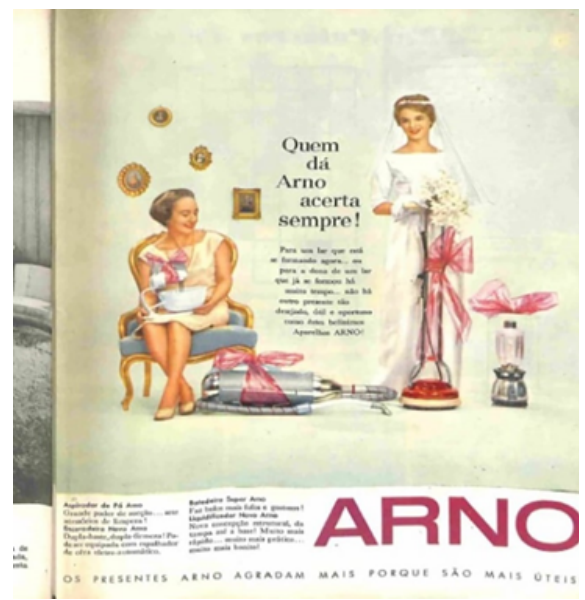

Fonte: Querida, maio de 1960. Acervo CEDOC, UNICENTRO - IRATI. 
No anúncio anterior a Arno faz uma sugestão de presente de casamento com os produtos da marca. Uma mulher aparece presenteando a noiva com eletrodomésticos. As donas de casa adquiriam produtos modernos para auxiliar em funções femininas tradicionais, esses novos produtos prometiam tornar a vida da "mulher moderna" mais prática.

Dessa forma, Querida propagava a representação da mulher através de papéis femininos tradicionais (dona de casa, esposa, mãe) e características que compunham a essência feminina (beleza, moda, culinária, doçura, recato, etc.) criando padrões de beleza e feminilidade:

Com seus inúmeros conselhos às esposas sobre como cumprirem a sua "função" relativa à "harmonia doméstica e conjugal", as revistas se dizem favoráveis à mulher. No entanto, uma análise mais profunda das revistas da época pode revelar formas de manutenção da dominação masculina sem enfrentamentos diretos, conflitos ou questionamentos nas relações homemmulher. Estas se traduzem, por exemplo, no controle da sexualidade feminina, na divisão rígida de atribuições e tarefas no casamento (relegando às mulheres espaços menos valorizados socialmente), na "dupla moral sexual", na submissão, na falta de diálogo entre iguais e nas responsabilidades distintas atribuídas ao feminino e ao masculino com relação à "felicidade conjugal” (BASSANEZI, 2006, p. 144).

Nos periódicos analisados foram encontrados aspectos de uma cultura machista e conservadora, além de criar e reproduzir padrões presentes nos "anos dourados", tudo era sempre para agradar ao sexo masculino e muitas colunas da revista foram escritas por homens. 
Para as mulheres a modernidade não estava presente na modificação do ser, na maneira de pensar, mas sim na forma de consumo. Para tornarem-se modernas as mulheres precisavam adquirir os produtos modernos: eletrodomésticos, maquiagens, produtos de higiene, acessórios, elas deveriam "ter para ser" (COSTA, 2009, p. 215).

A partir da história oral pudemos observar que as trajetórias das três leitoras entrevistadas foram diferentes, mas em alguns pontos se cruzam, principalmente as histórias de Canceriana e Sagitariana. Assim, nos anos 1960 a imagem das mulheres estava muito ligada à esfera doméstica e Querida criava e reforçava esses padrões de feminilidade.

\section{CONSIDERAÇÕES FINAIS}

Os discursos presentes na revista fazem parte da sociedade brasileira da década de 1960; Querida difundia, criava e reforçava representações e padrões de mulheres e homens. Nesta pesquisa foram analisadas as representações mais frequentes de mulher que eram a de esposa, a mãe, cuidadosa, caprichosa, responsável por múltiplas quase sempre inseridas dentro do lar. Envolvidas em discursos que apresentam a modernidade entrelaçada com a tradicional imagem feminina.

A modernidade representada por Querida não mudava as maneiras de pensar e agir das mulheres, mas sim o ter, adquirir produtos modernos para ter uma vida facilitada por eles. Nas páginas da revista o papel da mulher classe médiaalta continuava a ser o mesmo, o tradicional.

A história oral permitiu o acesso à memória das leitoras que confirmaram o discurso da revista, até mesmo porque Querida não estava "alheia ao mundo" ela estruturava seus 
assuntos de acordo com o que a sociedade pensava e queria ler. Pois Querida era um produto e uma produtora de símbolos sociais.

\section{FONTES}

CANCERIANA. Entrevista concedida a Cibeli Grochoski, Irati, 07 maio. 2018.

LEONINA. Entrevista concedida a Cibeli Grochoski, Irati, 07 maio. 2018.

SAGITARIANA. Entrevista concedida a Cibeli Grochoski, Irati, 26 agosto. 2019.

REVISTA QUERIDA, Janeiro de 1960, $1^{\text {a }}$ Quinzena, $n^{\circ}$ 135. Rio de Janeiro: Rio Gráfica Editora.

REVISTA QUERIDA, Maio de 1960, $1^{\text {a }}$ Quinzena, $\mathrm{n}^{\circ}$ 143. Rio de Janeiro: Rio Gráfica Editora.

REVISTA QUERIDA, Setembro de 1960, $2^{\mathrm{a}}$ Quinzena, $\mathrm{n}^{\circ}$ 152. Rio de Janeiro: Rio Gráfica Editora. Acervo: CEDOC/ UNICENTRO, Campus Irati.

REVISTA QUERIDA, Janeiro de 1962, $1^{\text {a }}$ Quinzena, $n^{\circ}$ 183. Rio de Janeiro: Rio Gráfica Editora.

\section{REFERENCIAS}

ALVAREZ, Palmira Virgínia Bahia Heine. A discursivização da mulher no lar na década de 1950 no periódico Jornal das Moças. TABULEIRO DE LETRAS, v. 02, p. 1-15, 2017.

BASSANEZI, Carla. Mulheres nos anos dourados. In: DEL PRIORE, Mary (Org.) História das Mulheres no Brasil. São Paulo: Contexto: UNESP, 2006, p. 607-639.

BOSCHILIA, Roseli Terezinha. Modelando condutas: a educação católica em colégios masculinos (Curitiba 1925-1965). 2002. 249 f. Tese (Doutorado em História). Universidade Federal do Paraná - UFPR, Curitiba. 
COSTA, Maria Paula. Entre o sonho e o consumo: As representações femininas na revista Claudia (1961-1985). 2009. 234 f. Tese (Doutorado em História) - Faculdade de Letras e Ciência de Assis - UNESP, Assis.

DAVIS, Natalie Zemon. Nas margens: Três mulheres do século XVII. São Paulo: Companhia das Letras, 1997.

DEL PRIORE, Mary. História do amor no Brasil. São Paulo: Contexto, 2005.

LOURO, Guacira Lopes. Mulheres na sala de aula. In: DEL PRIORE, Mary (Org.) História das Mulheres no Brasil. São Paulo: Contexto: UNESP, 2006, p. 223-240.

MARTINS, Ana Paula Vosne. "Um lar em terra estranha": A aventura da individualização feminina. A casa da estudante universitária de Curitiba nas décadas de 50 e 60.1992. 143 f. Dissertação (Mestrado em História) Universidade Federal do Paraná - UFPR, Curitiba.

PERROT, Michele. Práticas da memória feminina. In: Revista Brasileira de História. São Paulo, v.9, n. 18, p. 9-18, ago./set. 1989.

PINSKY, Carla Bassanezi. A era dos moldes rígidos. In: PINSKY, C. B.; PEDRO, J. M. (Orgs.). Nova História das mulheres no Brasil. São Paulo: Contexto, 2012.

2014.

Mulheres dos Anos Dourados. São Paulo: Contexto,

QUADROS JR, Itanel B. A propaganda no Brasil: uma brevíssima resenha do século XX. In: XXIV Congresso Brasileiro de Ciências da Comunicação Campo Grande, 2001, Campo Grande - MS. Anais do XXIV Congresso Anual em Ciência da Comunicação, Campo Grande, MS,, 2001. V. 01. p. 01-10.

RAMOS, Márcia Ziebell. Trabalho, subjetividade e reabilitação profissional: Por uma genealogia dos modos de vida. 2005. $92 \mathrm{f}$. Dissertação (Mestrado em Psicologia) - Universidade Federal do Rio Grande do Sul, Porto Alegre.

SALERNO, Laura Peretto.Querida ensina: Preceitos de comportamentos femininos em páginas da revista Querida (1958-1968). Florianópolis, 2009. 140 f. Dissertação (Mestrado em Educação) - Universidade do Estado de Santa Catarina, 2009.

SASAKI, Silvia. Smoking Fetiche. As representações femininas nas propagandas de cigarro (1940-1960). Seminário Internacional Fazendo Gênero 9: Diásporas, Diversidades, Deslocamentos. - Florianópolis: Universidade Federal de Santa Catarina, 2010. 
SILVA, S.C; STAFUZZA, G.B. Práticas identitária da autoajuda no mundo contemporâneo do trabalho. Psicologia \& Sociedade, v.25, p. 718-727, 2013.

SOARES, A. C. E. C; BARROS, N. C. F. As propagandas da revista feminina (1914-1936): A invenção do mito da beleza. Oficina do Historiador, Porto Alegre, EDIPUCRS, v.7, n.1, jan/jun. 2014, p.106120. 


\section{CAPÍTULO 8}

\section{MULHERES GENIAIS:}

\section{A MULHER E A PRODUÇÃO DO SABER A PARTIR DO OLHAR DE MONTSERRAT ROIG}

Katia Aparecida da Silva Oliveira (UNIFAL-MG)

Em meio ao contexto da Transição Espanhola, ocorrida entre o fim da década de 1960 e meados de 1980, nota-se o crescimento exponencial de uma produção intelectual feminina que consegue ganhar alguma visibilidade graças ao início da abertura política e aos tímidos avanços no sentido da retomada dos direitos civis das mulheres. Inspirada pelos acontecimentos de maio de 1968 e pela segunda onda do feminismo, observa-se nessa produção a reflexão acerca do lugar da mulher espanhola e a discussão relacionada a seu espaço como intelectual e artista. Destacam-se nesse período publicações literárias de escritoras como Rosa Montero, Ana Maria Moix ou Esther Tusquets; além de participações femininas em diferentes meios de comunicação como revistas, entre as quais a conhecida Vindicación Feminista ${ }^{1}$, criada e escrita por mulheres; jornais (com contribuições em colunas autorais, especialmente); ou mesmo a televisão

1. Vindicación Feminista foi publicação periódica de orientação feminista que foi publicada entre 1976 e 1979. 
ou o rádio, onde escritoras como Montserrat Roig ganham reconhecimento nacional e internacional.

Uma das grandes discussões nesse período é a da retomada da história das mulheres, defendendo que esse conhecimento permitiria que as mulheres tivessem mais consciência de si e de seu lugar social. Dentro dessa discussão é possível apontar a especial posição da história de mulheres na produção de conhecimento, identificando intelectuais e evidenciando as dificuldades encontradas pela mulher para se firmar nos âmbitos da ciência e das artes.

Em 1980 Montserrat Roig (1946-1991) publica o livro ¿Tiempo de mujer?, no qual reúne ensaios e artigos que tinha publicado sobre temas relacionados à mulher, ao feminismo, à memória e à história das mulheres. Sobre a obra, Christina Dupláa (1996, p.99) comenta que:

En ¿'Tiempo de mujer? se almacenan diversas entrevistas y escritos relacionados con las mujeres y su lucha por la obtención de un trato igualitario sin renunciar a su realidad femenina. Es, quizás, un buen intento de combinar lo femenino con lo feminista, aunque dentro del feminismo de aquellos años este intento es poco comprendido por muchas mujeres feministas.

Há nesse livro um ensaio intitulado ¿Por qué no ha habido mujeres genio?, que aborda a questão da ausência feminina nas artes e ciência, discutindo a história das mulheres e sua inserção no campo literário. Conectando-se com os temas apresentados pelos outros textos da obra, o ensaio ¿Por qué no ba habido mujeres-genio? discute tanto o feminino, como o feminismo, e pensa na mulher como alguém capaz de desenvolver papeis sociais e criativos diversos, sem deixar, porém, de denunciar a dificuldade de inserção feminina em meios dominados pela tradição patriarcal. 
Esse texto, que já tinha sido publicado em uma primeira versão, com o mesmo título três anos antes, na revista Vindicación Feminista, tem alguns de seus argumentos recuperados em outras publicações da autora: o romance L’hora violeta (1980) e o livro ensaístico Digue que m'estimes encara que sigui mentida (1991), considerado o testamento literário de Roig. Esses argumentos em obras diferentes mostram como Roig entende a importância da discussão acerca do lugar da mulher como produtora de saberes.

¿Por qué no ha habido mujeres genio? parte de uma situação cotidiana - um diálogo com um intelectual francês -, que surge como pretexto para aprofundar a discussão sobre o lugar da mulher no âmbito da criação intelectual, e mais especificamente da criação literária, rebatendo a ideia de que não seria possível haver mulheres-gênio. $O$ texto é composto de três partes - Y Helena, ¿estaba de acuerdo?, ¿Palabra de mujer? e Un útero para el artista -, das quais somente a primeira havia aparecido no artigo de 1977.

Pode-se dizer que esse ensaio tem um tom assertivo, mas mantém uma linguagem simples. Diferentes escritores de obras literárias, críticas ou teóricas, participam da argumentação que o compõe: de Virgínia Woolf a Simone de Beauvoir, ou de Flaubert a Antonio Machado ou Nietzsche. Essa construção intertextual do ensaio, além de revelar conhecimento e autoridade na apresentação do tema, pode ser compreendida como uma estratégia para mostrar como o conhecimento interage e como a discussão de temas complexos precisa se encontrar com diferentes perspectivas.

Nesse sentido, o objetivo desse trabalho é analisar os argumentos de Montserrat Roig acerca da ausência das mulheres, ou da menção a elas, nos contextos de produção de saberes, destacando-se a produção literária. Pretende- 
se reconhecer os diálogos que a escritora estabeleceu em seu texto com diferentes fontes e autores, de forma a construir uma leitura de ¿Por qué no ha habido mujeres genio? contextualizada e capaz de revelar a perspectiva sobre o tema que a autora apresenta.

\section{ONDE ESTÃO AS MULHERES NOTÁVEIS?}

¿Por qué no ha habido mujeres genio? é um ensaio construído em torno de alguns grupos de argumentos, que elaboram uma perspectiva multifacetada e intertextual sobre o lugar da mulher na produção do conhecimento. Para esta análise, organizo tais argumentos em quatro grupos: (i) o homem e o feminismo; (ii) o tabu e a biologia; (iii) arqueologia feminina e (iv) em busca de uma voz.

Antes de analisar os argumentos individualmente, vale ressaltar que o texto se organiza a partir de um acontecimento ficcional: o encontro da narradora/autora com um intelectual francês, com quem estabelece um diálogo que motiva as reflexões apresentadas. Essa estrutura que se estabelece em torno e a partir de um diálogo surge como um recurso que ao mesmo tempo em que introduz a temática que será desenvolvida, ganha a empatia do leitor que se envolve com uma discussão teórica sem notar.

\section{O HOMEM E O FEMINISMO}

O primeiro argumento dos textos está associado à figura do intelectual francês, um homem descrito como "un francés cartesiano y a la vez modelado por el Mayo del 68" (ROIG, 1980, p. $147)^{2}$. O personagem, apesar de estabelecer com a narradora

2. Todas as citações do ensaio ¿Por qué no ha habido mujeres genio? são retiradas 
um diálogo estimulante, não reage bem à introdução do "tema da mulher" à conversação:

El joven y bello francés daba chupadas intermitentes a su pipa mientras disertaba y se complacia ante el saludable ejercicio de la especulación ideológica. Todo iba a pedir de boca hasta que le tocó el tema. Quiero decir el tema de la mujer. El francés se olvidó entonces de sus ideas progresivas, de su capacidad crítica y de su lucider: Como tantos otros jóvenes, bellos e inteligentes ejemplares, esbozó una sonrisa y trató de evitar el diálogo sobre algo tan menor y tan poco metafísico como es el tema de la mujer y su marginación en el campo de la cultura. Empezó a abusar del tópico y de las banalidades, se sentía agredido y la pipa funcionaba a cien por hora. Ya se sabe, aquello de que las mujeres no ban inventado nunca nada importante, no han creado una gran obra de arte, no son grandes científicos, etc. ¿Cómo podéis crear la novena sinfonía, por ejemplo, si tenéis que llevar a cabo la función de la maternidad? (p. 147)

$\mathrm{O}$ intelectual se mostra como alguém disposto a conversar sobre diversos temas, como alguém que aprecia um bom diálogo. No entanto, quando se chega à discussão sobre a mulher, vista como menor, evidencia-se a perspectiva de que os debates relacionados ao feminino não seriam dignos de reflexão, acadêmica ou não. A sua lucidez se esvai, revelando desprezo e agressividade em relação à discussão. A ausência de produção intelectual feminina é relegada, assim, a algo sem importância. Até a biologia feminina, marcada pela maternidade, é usada como pretexto para justificar uma suposta falta de inclinação das mulheres à criação de saberes.

de: ROIG, Montserrat. ¿Por qué no ha habido mujeres genio? In: ROIG, Montserrat ¿'Tiempo de Mujer? Barcelona: Plaza y Janés, 1980. p. 145-166. A partir desse momento indicaremos somente a página em que se encontram os textos mencionados. 
Esse argumento, ressaltado depois pelo francês com a provocação "A ver, explícame por qué no ha habido ninguna mujer como Einstein" (p. 148), instiga o desenvolvimento do texto de Roig. A resposta dada ao personagem francês abre caminho para as ponderações que serão desenvolvidas com detalhe nos textos: "Y explicame tú donde estaria tu Einstein si en su época bubiera nacido negro" (p. 148).

Nesse sentido, acompanhando o pensamento de Simone de Beauvoir de que "Ningún destino biológico, psíquico, económico, define la imagen que reviste en el seno de la sociedad la bembra bumana; el conjunto de la civilización elabora este producto intermedio entre el macho y el castrado que se suele calificar de femenino" (2013, p. 371), nota-se que Roig entende que a mulher é fruto de um pensamento ideológico, social e histórico, de forma que sua ausência na produção científica e artística seria decorrente dessa realidade.

A filiação ao pensamento de Beauvoir, além de outras pensadoras, como Kate Millet e Betty Friedan, entre outras, é marcado em toda a obra de Montserrat Roig, desde a ficcional à ensaística e periodística, ou mesmo à televisiva. Esse diálogo com o pensamento feminista, efervescente após os eventos de maio de 1968, é parte da formação da autora, que no fim dos anos 60 estava na universidade e participava de grupos políticos e intelectuais da Barcelona da Transição política. Nesse sentido, Dupláa (2005, p. 305) comenta que "Roig dedicó veinticinco años de su corta vida a la creación de un complejo universo literario compuesto de ensayos feministas, ficciones centradas en la mujer, la presencia constante de su ciudad natal, Barcelona, y su lengua minoritaria, el catalán".

Em seu acervo, hoje depositado no Arxiu Nacional de Catalunya, é possível encontrar fichamentos e anotações feitas por Roig acerca de importantes obras do feminismo. 
No caso de ¿Por qué no ha habido mujeres genio?, é perceptível a relação intertextual que estabelece com essas obras, em alguns momentos mencionando-as objetivamente, em outros retomando ideias de forma sutil e até mesmo didática. Nesse sentido, observa-se como a escritora se constitui como intelectual em frequente atualização e como promove em sua obra um olhar comprometido, que leva ao leitor ou ao espectador discussões produzidas no âmbito acadêmico e intelectual de forma acessível, alcançando diferentes públicos.

O questionamento sobre um Einstein negro faz com que o interlocutor francês do ensaio silencie, demonstrando descontentamento e incômodo. A narradora relaciona esse silêncio a um medo associado ao tema da mulher, um medo que, segundo ela, ataca o subconsciente e o poder masculino. É como diz Rosiska Oliveira:

No imaginário masculino, as mulheres, percebidas não só como diferentes mas, sobretudo, como inferiores, ocupam, paradoxalmente, o lugar de "metade perigosa da sociedade". Mais perto da natureza selvagem que da "paisagem humanizada", detentoras da fertilidade da terra e da fecundidade do grupo, delas provém a ameaça suprema de que, caso rompam a relação primordial de alteridade/ oposição e recusem-se aos homens, estiole-se o solo e aniquile-se a espécie. (OLIVEIRA, 2012, p. 47).

Esse temor à mudança que se associa às discussões do feminismo, atacadas como menores ao mesmo tempo que perigosas, estaria associada a uma perspectiva pautada pelo patriarcado e pelo poder que atribui ao homem. Nesse sentido, a narradora continua: "El bello francés pretende verse agredido como hombre, cuando, en realidad, se le ataca como patriarca" (p. 148). Nota-se como a discussão proposta no ensaio se projeta 
sobre um sistema de poder e de valores conscientes ou não: frente ao feminismo é o patriarcado que vacila, que é atacado, não o homem.

A questão da mulher e do medo, ou da indisposição, a (re)discutir sua condição social levam à revisão de um imaginário coletivo, um subconsciente que firma as bases do patriarcado. $\mathrm{O}$ argumento de Roig propõe que as discussões do feminismo devem ser compreendidas para além de normativas ou considerações que não busquem transformar o que está oculto em camadas subjacentes à consciência. Como comenta, "el tema de la mujer hace tambalear la estructura consciente del hombre, desarrollada a través de la cultura y de la historia. [...] La lucha de las mujeres pone en peligro el equilibrio que habia conseguido y que habia simbolizado en la familia nuclear, en el hogar, dulce hogar" (p. 148).

No caminho para a transformação da perspectiva do homem, Roig considera que este teria obrigatoriamente de passar por um processo de reconhecimento de seu papel como opressor e como parte integrante de uma tradição histórica firmada em masculino. Como afirma: "Sólo el hombre que es capaz de mirarse a sí mismo como sexo opresor puede llegar a liberarse como ser humano. Sólo el hombre que llegue a comprender que la historia de la Humanidad ha sido explicada, hasta el momento, a través de la óptica masculina" (p. 149). A partir dessa perspectiva, seria necessária uma conscientização do homem no que se refere a seu lugar social, inclusive como forma de libertação de um sistema tão desigual.

A liberdade seria, aliás, um dos principais objetivos do feminismo para Roig. Em seu livro El feminismo ${ }^{3}$ (1986, p. 5), ela propõe que o feminismo defende a liberdade das

3. Publicado pela primeira vez em 1981 sob o título Mujeres en busca de un nuevo bumanismo. 
mulheres e em consequência dela, a liberdade dos homens, que só poderiam ser verdadeiramente livres se deixassem de oprimir às mulheres.

Os argumentos que desconstroem o mito de que a mulher está biologicamente propensa à submissão e ao cuidado dos filhos e família permitem um olhar à realidade feminina mais centrada em valores construídos socialmente, abrindo espaço para os próximos argumentos que serão abordados no ensaio. A questão que se propõe é a de que não há uma biologia que impeça a mulher de ser uma intelectual, é o ambiente em que é inserida que a limita e não permite seu desenvolvimento.

\section{O TABU E O LUGAR DA MULHER}

Outro argumento que surge no texto está associado à biologia feminina e o consequente lugar social ocupado pela mulher. O corpo feminino e a maternidade, entendida pela narradora como o maior tabu associado ao feminino, acabam sendo usados como artifício para a opressão das mulheres. Vemos, assim, como o personagem francês encarna um olhar pautado em uma série de valores historicamente associados à mulher (¿Cómo podéis crear la novena sinfonía, por ejemplo, si tenéis que llevar a cabo la función de la maternidad?), especialmente os que a condenam à sua biologia:

Mi francés no sólo tenía miedo de mi agresividad verbal, de mis razonamientos. [...] En el fondo, respondía al temor ancestral frente a la biología de la mujer. Cuando afirmaba que las mujeres no seríamos nunca creadoras en el campo de la ciencia o de la cultura y nos enmarcaba en nuestra condición natural de animal reproductor, no hacia más que ser fiel a sus antepasados primitivos que inventaron el tabú para controlar el misterio de la biología 
femenina. Cuando el hombre se da cuenta de que la procreación está totalmente en manos de la mujer, cuando ve que sólo va a ser comparsa, es cuando inventa el mito (p. 150).

O tabu da maternidade, ao mesmo tempo sagrado e profano, revela como, para a autora, a incompreendida biologia feminina foi domesticada. A escritora Marta Colomina de Rivera, em sua obra La Celestina Mecánica: estudio sobre la mitología de lo femenino, la mujer y su manipulación a través de la industria cultural (1976), que figura entre as leituras de Montserrat Roig, comenta que em uma sociedade primitiva a força bruta feminina, menor, em comparação à masculina, poderia ter sido considerada um signo de inferioridade, que unido à diferença física e à capacidade de gerar novas vidas estabeleceriam "suficientes bases para ideologizar un proceso que se convertiría en un mito justificador de la opresión que durante siglos ha sufrido la mujer como algo 'natural' a su esencia femenina" (COLOMINA DE RIVERA, 1976, p. 114).

Assim, o mito da inerente disposição feminina à maternidade e à estima e fixação no espaço doméstico, validaria o controle patriarcal sobre a mulher e seu corpo. O sistema simbólico construído ao redor da figura feminina define a mulher a partir da diferença, da estranheza e do contraste frente a valores masculinos e de poder. A relação de alteridade que se destaca reflete o olhar para a mulher como o "outro", aquele que se caracteriza pela oposição, pelo inverso:

Las pruebas aportadas por la antropología, asi como los mitos religiosos y literarios, corroboran la conveniencia politica de las convicciones patriarcales relativas a la mujer. [...] La mujer no acuñó los simbolos con los que se la describe en el patriarcado: tanto el mundo primitivo como el civilizado son masculinos y la idea cultural de la mujer es obra exclusiva del varón. El hombre creó la imagen de 
la mujer que todos conocemos, adaptándola a sus necesidades. Señalemos que éstas resultan, en gran parte, del temor que le inspira la "alteridad" de su compañera, noción que presupone la existencia del patriarcado y la implantación del varón como norma bumana, como sujeto absoluto respecto del cual la mijer no es sino el "otro"; es decir, un extraño (MILLET, 2010, p. 105).

Nesse sentido, sendo a mulher o "outro" em relação ao homem, entendida como uma manifestação do primitivo frente ao civilizado masculino, recebe um sistema simbólico que a relega a um lugar subjugado, definido por sua natureza biológica, e a um espaço considerado inferior pelo patriarcado, o doméstico. Para $\mathrm{M}^{\mathrm{a}}$ Ángeles Cabré "El temor a la diferencia, que anidó en los varones como una incorregible certeza, se tradujo en una mirada descaradamente misógina, y esta a su vez en la creación de la mujer objeto, una cárcel perfecta para no dejar que saliera de ella jamás" (CABRÉ, 2013, p. 211), ou seja, para a autora a objetificação da mulher seria uma forma de dominar uma natureza incompreendida, uma forma de controle àquilo que é entendido, de certa maneira, como indomável.

Para Roig, o estranhamento que surge ao contato com a diferença estaria na essência do medo que toma o homem em relação à mulher, um medo inconsciente que representaria o temor de não dominar a natureza e o mistério da biologia feminina, especialmente ao considerar a maternidade. Esse medo seria o responsável por relegar a mulher ao papel de reprodutora:

Tras ese dominio se ha desarrollado la ideología de las esencias, la cual ha proclamado que la maternidad era un destino insoslayable. A partir de aqui, la maternidad ha sido idealizada $y$ sublimada, pues de otro modo las mujeres no bubieran aceptado impunemente su postración. La mujer no se ha liberado de su destino, de abi que 
el sufrimiento y la resignación, productos culturales de esa postración, parece que formen parte de la naturaleza de la mujer. $Y$ la resignación es la principal enemiga de la creación artística, la cual se nutre fundamentalmente del impulso de libertad. Es imposible imaginar a un Beethoven pariendo año tras año, a Einstein especulando sobre la teoría de la relatividad entre críos que lloran, a Miguel Angel trabajando en la Capilla Sixtina mientras cada tres horas tiene que dar de mamar a sus bijos. Hay una imposibilidad fisica, real, que ha mantenido a la mujer apartada del campo de la creación (p. 152).

A sublimação da maternidade é um recurso que levaria as mulheres a aceitarem seu papel como reprodutoras e se resignarem com o lugar social que lhes é atribuído. Essa simbologia que insere a maternidade num plano quase divino atua muito mais em favor do sistema patriarcal do que em favor das mulheres. É nesse sentido que Montserrat Roig defende que a maternidade e todas as suas atribuições acabariam se transformando em obstáculos para que as mulheres pudessem ocupar um espaço como intelectuais, artistas ou cientistas.

Mas a maternidade não seria o único entrave na vida daquelas que desejassem se inserir no universo do saber: o cuidado com a casa, com o marido e demais membros da família, tomar-lhe-iam todo o tempo e energias de que dispusesse. Assim, quando as mulheres são comparadas aos grandes homens-gênio da história, nota-se como a maternidade e os deveres para com a família, atribuídos a elas, se convertem em atividades que limitam ou impedem a aproximação e dedicação exclusiva à produção intelectual.

Associado à maternidade, o espaço doméstico que foi destinado às mulheres acabou se transformando em um âmbito definido pela ausência de poder e impedimento de 
atuação no âmbito público. A resignação feminina diante do poder masculino fez com que a mulher não tivesse acesso ao dinheiro ou a propriedades, impedindo o controle de seu destino. Para Roig:

La mujer no tiene ninguna clase de poder en todo el mundo. En elprimer estadio de nuestra liberación, de nuestra autonomia creadora, hay que desprivatizar el poder económico. Las mujeres siempre hemos sido pobres, el dinero ha sido del padre, del marido, del hermano. Incluso las abadesas de la Edad Media, que tenian su aislada parcela de poder, eran elegidas por el obispo de su diócesis. Para crear, bay que tener un cierto distanciamiento de la vida cotidiana, no estar atada a los problemas concretos de la organización doméstica. [...] Parafraseando a Virginia Woolf, para escribir es necesaria una renta anual y una habitación propia (p. 153).

Tomando as palavras de Virgínia Woolf, Roig defende a necessidade de uma renda e de um espaço próprio para que uma mulher tenha liberdade para se dedicar ao conhecimento. Sabe-se que por séculos o espaço da mulher era compartilhado pela família e um lugar particular para a reflexão, para a escrita (quando se tinha acesso às letras) ou para criações artísticas de diferentes naturezas era, na maior parte dos casos, inexistente. Dessa forma "las paredes de las casas han acumulado gemidos y pensamientos oscuros, susurrosy conversaciones rotas" (p. 153). Retomando Virginia Woolf:

A liberdade intelectual depende de coisas materiais. A poesia depende da liberdade intelectual. $\mathrm{E}$ as mulheres sempre foram pobres, não só por duzentos anos, mas desde o começo dos tempos. As mulheres gozam de menos liberdade intelectual do que os filhos dos escravos atenienses. As mulheres, portanto, não tiveram a mais remota chance de escrever poesia. É por 
isso que dei tanta ênfase ao dinheiro e ao espaço próprio (WOOLF, 2014, p. 151).

Nota-se como o espaço doméstico, junto ao sistema simbólico associado às mulheres, acaba sendo um elemento limitador do desenvolvimento feminino, não só pela ausência de um espaço físico para si, mas também pela dependência material em relação aos homens e à consequente impossibilidade de atuação no âmbito público. A falta de liberdade intelectual é ligada à falta de liberdade material e à carência de acolhida no espaço público.

Como defende Woolf, a liberdade intelectual, desejável para aquelas que busquem se dedicar à criação artística ou a estudos acadêmicos diversos, está vinculada à existência de uma liberdade econômica, algo que ainda hoje não é realidade para muitas mulheres. Como comenta Kate Millet (2010, p. 94): "Por lo general, la posición que ocupa la mujer en el patriarcado constituye una función continua de su dependencia económica. Su relación con la economía es tan directa o tangencial como su situación social, adquirida en numerosos casos con carácter pasajero o marginal'.

Percebe-se como a tradicional ausência feminina da história do conhecimento ou das artes vai se delineando no ensaio de Roig como parte de um sistema social excludente, no qual a mulher ocupa um lugar subordinado. Essa ausência não é resultado de uma falta de aptidão ou capacidade intelectual, mas de uma organização social que impede ou dificulta às mulheres, por um lado, o seu acesso ao conhecimento e que, por outro, não lhe fornece condições espaciais e materiais para que produza algum tipo de saber. 


\section{AROUEOLOGIA FEMININA}

Mas além da falta de liberdade ou de condições materiais para o desenvolvimento intelectual feminino, a ausência de uma história das mulheres e, consequentemente, do conhecimento acerca da existência de mulheres intelectuais, pode ser entendida como um entrave para o acesso feminino ao universo da criação intelectual. Desconhecer o passado das mulheres e a história daquelas que se destacaram gera uma falta de perspectiva em novas gerações e a sensação de que nunca houve mulheres gênio, como se não fosse possível mudar essa suposta realidade.

Como comenta Montserrat Roig, o conhecer o passado das mulheres é algo que deve fazer parte da experiência de todas e da própria tradição intelectual:

En el primer estadio de nuestra liberación, la consciencia de ser mujeres nos obliga a convertirnos en arqueólogas de nuestro sexo. Bucear en la prehistoria de nuestro cuerpo, denunciar la parcialidad de la tradición y de la cultura que se nos ha enseñado - pues no existe sólo la cultura de la clase dominante sino también la del sexo dominante. Dejar de existir para lo uno siendo lo otro (p. 154).

Ao reconhecer a ausência da figura feminina de boa parte dos relatos do passado, a necessidade de uma arqueologia da história das mulheres se destaca. Conhecer aquelas que nos antecederam, suas experiências, suas conquistas e seu cotidiano, seria parte essencial de uma autoconsciência, do reconhecimento de um lugar histórico e da ideia de pertencimento a uma tradição.

Assim, ter acesso à história das mulheres permite a construção de uma identidade, nesse caso, uma identidade que leva o indivíduo a se perceber como herdeiro e parte 
de um coletivo. Esse processo de reconhecer o passado permite que novas gerações reconheçam que podem seguir os passos de suas antecessoras, conquistar novos espaços e criar novos saberes. A arqueologia da história feminina que propõe a escritora catalã permitiria a elaboração de um discurso histórico pelo viés feminino. Seria uma recuperação e revisão do passado registrados pela perspectiva da mulher, colaborando para a constituição de uma identidade coletiva e de uma tradição.

A adoção do termo arqueologia, no caso da história das mulheres, é acertada, já que para recuperar esse passado é preciso escavar, procurar e preencher vazios. Observa-se como são escassos os relatos históricos que se dediquem a discutir a participação feminina em sociedades de diferentes épocas. A arqueologia proposta assumiria o papel de resgatar essas histórias ignoradas e silenciadas.

Não se pode desconsiderar, porém, que esse esquecimento ou apagamento das mulheres do relato histórico, como menciona Michelle Perrot, não é fruto do acaso:

O relato histórico é olhar, escritura, artefato, não artificio, certamente, mas escolha intimamente ligada ao presente do escritor. O esquecimento de que as mulheres têm sido objeto não é uma simples perda de memória acidental e contingente, mas o resultado de uma exclusão consecutiva à própria definição de História, gesto público dos poderes, dos eventos e das guerras. Excluídas da cena pública pelas funções ditadas pela "natureza" e pela vontade dos deuses/ de Deus, as mulheres não podiam aparecer nela a não ser como figurantes mudas, penetrando por arrombamento ou a título de exceção - as mulheres "excepcionais", heroicas, santas ou escandalosas -, 
relegando à sombra a massa das outras mulheres (PERROT, 2009, p. 112).

Esse apagamento das mulheres dos relatos históricos pode ser entendido como uma forma de reafirmação do poder patriarcal. Excluídas as mulheres que não realizaram "grandes feitos", segundo os valores de quem escrevia a História, somente as mulheres excepcionais eram dignas de alguma menção, porém, ainda assim, padecendo pelo julgamento de quem detinha o poder.

No caso de mulheres que porventura conseguissem se aventurar no caminho da produção intelectual, o julgamento poderia ser implacável. Como comenta Cabré:

En todos los tiemposy en todos los lugares, las mujeres sufrieron durante sus trayectorias intelectuales toda clase de zancadillas por miedo a que subvirtieran el orden establecido aportando su propia visión del mundo, que se anunciaba tan distinta. Hildegarda de Bingen tuvo que enfrentarse al clero de Maguncia, que la cuestionó, y Sor Juana Inés de la Cruz. llegó a ser silenciada en vida. Acabaron siendo pues excepciones las que se bicieron un bueco en un panorama perennemente androcéntrico: las dos citadas, Juliana de Norwich, Christine de Pizan, Maria de Francia... Asimismo, incluso alejadas de la observación eclesiástica, cualquier excusa era buena para animarlas a dejar de escribir. Aquejada de una de sus fuertes depresiones, el médico probibió a Charlotte Brontë que cogiera la pluma, augurándole pésimas consecuencias. $Y$ otro tanto le sucedio a Virginia Woolf por la misma razón décadas después, ya en pleno siglo XX.(CABRÉ, 2013 , p. 210).

A inserção feminina no ambiente intelectual sofreu muita resistência, como menciona Cabré. Reconhecer a possibilidade de que as mulheres pudessem estabelecer uma vida para além do ambiente doméstico tem sido há séculos 
algo difícil de consolidar. Roig argumenta que "es arduo reivindicar el propio sexo, tener que demostrar a cada momento, sin renunciar a toda la riqueza de nuestra condición especifica y diferente, que somos tan aptas como ellos, los hombres" (p. 156).

A falta de uma tradição histórica que registre a participação de mulheres nos círculos intelectuais dificulta um processo de uma mudança de cenário. A própria ideia de cânone na literatura é problemática quando se pensa na produção intelectual feminina. Basta um breve passar de olhos em diferentes obras de história da literatura ou em prateleiras de livrarias ou bibliotecas para constatar a falta de menção ou o ínfimo número de obras escritas por mulheres, ainda hoje. A partir dessa perspectiva, deve-se recordar, como menciona Lúcia Zolin, que:

Historicamente, o cânone literário, tido como um perene e exemplar conjunto de obras-primas representativas de determinada cultura local, sempre foi constituído pelo homem ocidental, branco, de classe média/alta; portanto, regulado por uma ideologia que exclui os escritos das mulheres, das etnias não-brancas, das chamadas minorias sexuais, dos segmentos sociais menos favorecidos etc. Para a mulher inserir-se nesse universo, foram precisos uma ruptura e o anúncio de uma alteridade em relação a essa visão de mundo centrada no logocentrismo e no falocentrismo (ZOLIN, 2009, p. 327).

Pode-se considerar, junto a Cecil Jeanine Albert Zinani (2010, p. 66), que a inclusão das mulheres e de outros grupos desprivilegiados no cânone exige uma revisão que deve se associar a uma redefinição de literatura, questionando e reavaliando as relações de poder que lhe são implícitas. 
Como consequência, uma nova visão da literatura, de sua historicidade e de seus processos pode surgir.

Nesse sentido, Roig defende que não se deve rejeitar totalmente o universo cultural masculino e o que se conquistou com ele, desde as artes à ciência. Para ela, o que se tem de fazer é transformar esses saberes em experiência feminina, assimilando e se apropriando do melhor desse universo cultural para se expressar. A partir dessa perspectiva, é importante considerar que a apropriação proposta não poderia ser negada em função da defesa de uma cultura puramente feminina, já que "Defender la cultura sólo en femenino es afirmar la exclusividad de la cultura determinándola a un solo grupo, por mucho que éste se desarrolle condicionado por la opresión en la cual vive" (p. 159).

O trabalho de arqueologia da história das mulheres atuaria, também, nessa revisão do cânone, contribuindo para a reavaliação de seus valores e permitindo que a produção literária de mulheres seja reconhecida e prestigiada. Esse resgate histórico contribuiria com o processo de escrita de uma história das mulheres, destacando sua atuação artística e intelectual, além de permitir o registro dos contextos e das dificuldades relacionadas à escrita e publicação de seus textos.

De qualquer forma, o apagamento histórico da mulher cria a falsa sensação de que não é da natureza feminina participar de grandes momentos da história ou mesmo de se destacar em campos como as ciências ou as artes. Nesse sentido, a argumentação de Roig estabelece mais um ponto para justificar a ausência das mulheres no mundo intelectual: a falta de um discurso historiográfico que faça jus à história das mulheres e, consequentemente, a inexistência de uma tradição que permita que novas gerações de mulheres se espelhem 
em exemplos do passado e visualizem a possibilidade de se inserir nesse contexto.

\section{EM BUSCA DE UMA VOZ}

A arqueologia da história das mulheres, porém, não é capaz, somente ela, de assegurar a liberdade e a competência para criar algo artisticamente. Como processo revisionista do passado, a arqueologia contribui para uma consciência do que é ser mulher, podendo atuar como inspiração, mas não concede uma voz à artista:

El trabajo de arqueología es sólo un paso previo antes de encontrar nuestro propio lenguaje, particular y universal a la vez. Y a través del lenguaje establecer una relación autónoma con el arte. [...] Se trata de abandonarse, liberar los fantasmas, por penosos que sean, establecer la armonía entre la venganza y la reconciliación, liberar el subconsciente para dejar de ser plañideras. La experiencia no es igual en todas las mujeres que escriben, aunque haya rasgos comunes. El problema está en trabajar la propia experiencia e incluso llegar a manipular, literariamente y conscientemente, el resentimiento. La creación no es sólo fruto del resentimiento sino de la hábil utilización de los propios fracasos (p. 158).

Desenvolver uma voz própria é parte, assim, de um processo de construção da mulher artista, no qual a experiência é trabalhada de maneira a utilizar literariamente a linguagem. A escritora tem de lidar com as influências que recebe direta ou indiretamente, com a memória, com traumas e alegrias, transformando e manipulando a bagagem íntima 
que carrega. A subjetividade emerge de suas palavras e é sua força e seu calcanhar de Aquiles, afinal, a subjetividade feminina é entendida, ainda, como símbolo de fraqueza ou de leviandade. Nas palavras de Roig, "La mirada de mujer es mirada de escritora que se escribe y escribe el mundo. Pero todavia es considerada una mirada subjetiva, como si todas las miradas no fuesen subjetivas" (ROIG, 2001, p. 113).

Quando se pensa em obras escritas por mulheres, Roig considera que alguns gêneros ganham destaque, especialmente os que se apropriam do uso da primeira pessoa, como autobiografias, diários ou cartas. A subjetividade - a expressão do eu - é em muitos casos, o que se projeta por meio das palavras. Com isso, em uma tradição literária que ainda está buscando se estabelecer, observamos "el intimismo antes que la época. Todavía leemos obras que, a pesar de exbibir una forma literaria desinhibida y provocadora, no han adquirido suficiente autonomia frente al mundo de las ideas, no han sido capaces de establecer una relación única y no transmisora con el universo" (p. 160).

Junto à expressão da experiência e da perspectiva feminina, a escritora tem de lidar com o seu próprio imaginário, com o seu inconsciente carregado de tabus e de valores patriarcais absorvidos ao longo da vida, que mesmo a arqueologia da história das mulheres não é capaz de eliminar. Com isso, não é de espantar a dificuldade enfrentada para encontrar uma voz própria. Assim, em meio a esse processo de busca de uma voz, é possível observar como algumas manifestações literárias, ainda que escritas por mulheres, refletem uma perspectiva tradicionalmente masculina. Roig traz como ilustração o caso do livro Medo de voar (1973), de Érica Jong, a qual a escritora catalã considera escrever "como hombre la experiencia de mujer" (p. 160):

No es de extrañar, pues, el éxito que esta novela ha tenido entre los hombres. $Y$ esto es lo que lleva 
a Henry Miller a afirmar que Miedo a Volar es el equivalente femenino de su Trópico de cáncer. Pero lo que le gusta al escritor americano es que la Jong escriba como una "bembra", que se adbiera a su personal canto al paganismo, que contribuya, de alguna manera, a la escisión entre espiritu y cuerpo, pero baciendo lo contrario que los autores cristianos, poniendo el énfasis en el sexo. Aunque desde una óptica contraria, se ba roto de nuevo la armonía entre el cerebro, el corazón y el sexo. (p. 160).

Nesse caso, Jong reproduz em sua obra um reflexo do que Roig chama de escrita de homem. A abordagem que cria da autodescoberta sexual é representada a partir de um ponto de vista impregnado por tabus e por uma perspectiva masculina sobre a sexualidade feminina e sobre a própria escrita. Não se percebe, para Roig, a expressão de uma voz constituída a partir da experiência da escritora como mulher:

¿Puede una mujer crear un mundo de ficción verbalizando sólo su interiorizada condición sexual? Sí, si sólo se propone esto [...] Pero otras novelistas se dan cuenta que existe también la relación con los demás, con las ideas y con el mundo. $\mathrm{Y}$ que hay que bucear en todo ello para explicarse la particularidad de la propia existencia (p. 161).

Essa dificuldade de expressão da experiência da mulher, como se mencionou, vai perpassar o processo de conquista de uma voz. Roig comenta que em oposição ao trabalho de Jong, pode-se considerar que $O$ caderno dourado (1962), de Doris Lessing, é capaz de representar tanto o imaginário coletivo quanto a consciência individual. Lessing teria conseguido integrar a experiência particular ao que lhe é externo, pois "intenta conciliar los planos artístico, psicológico y literario. A partir del fracaso de una ideología que se proponía llegar a la totalidad en 
abstracto, las protagonistas de Doris Lessing optan por ser desmenuzadas, troceadas en un mundo concreto" (p. 161). Percebe-se que ao serem fragmentadas ou despedaçadas, as personagens de Lessing demonstram o que vai no íntimo, na natureza da experiência feminina, com alegrias, medos, tabus, ódios... A vivência do corpo feminino, da construção da mulher como ser social e como parte de uma comunidade, é transformada em palavras e em arte literária, trazendo à tona a voz da escritora.

Pode-se criar um paralelo entre os dois exemplos de Roig e a proposta que Elaine Showalter (1977) desenvolve em seu estudo sobre a literatura inglesa de autoria feminina entre os séculos XIX e XX, na qual sugere a existência de três fases da escrita feminina, denominadas como feminina, feminista e "fêmea" ou mulher (feminine, feminist, female). Com essas fases, ou etapas do processo de conquista de uma voz, a autora propõe a leitura das obras escritas por mulheres considerando a forma como representam a experiência feminina e se apropriam da literatura como forma de expressão.

Para Showalter (1977, p. 13), a fase feminina, na qual poderíamos inserir a obra de Érica Jong, seria marcada pela reprodução de estilos de escrita masculinos, de padrões estéticos e por valores culturais e sociais dominantes; já a fase feminista representaria o momento protesto contra esses padrões e valores, defendendo também a conquista de uma autonomia. Por fim, a fase "fêmea" ou mulher, apresentaria um momento de autodescoberta, de introspecção e uma busca de identidade. A essa última fase poderíamos integrar a obra de Doris Lessing.

Showalter, como se vê, entende que a escrita feminina por tanto tempo relegada a um segundo plano, acaba sendo um reflexo do processo de autoconsciência, de revisão do cânone e do lugar social da mulher, especialmente a partir do 
século XX, quando o feminismo ganha mais espaço. Devese ressaltar, entretanto, que esse processo não é linear e nem sempre as escritoras vivenciam cada uma das três fases ou se inserem em só uma: as formas de expressão e de vivência de cada escritora são únicas. As fases propostas por Showalter são não mais que parâmetros que auxiliam no estudo da literatura, revelando tendências observadas em diferentes produções de mulheres.

Montserrat Roig segue a trilha deixada pelas duas escritoras, Jong e Lessing, dialogando, de certa forma, com Showalter. Entendendo que desenvolver uma voz demanda dedicação, Roig aponta para o fato de que é preciso entender o que significa escrever a partir de uma perspectiva feminina e ponderar sobre sua relação com a arte e a cultura masculinas. Nesse sentido, chega a questionar a própria natureza dessa voz:

Cuando las feministas dicen que bay que descubrir la propia vozz ¿a qué voz se refieren? ¿La voz de los patios interiores? ¿La del rellano de la escalera? ¿La de los mercados, de los parques infantiles, la de la peluquería? ¿La voz que se emite entre pañales, entre la caca y el pipi de los críos? Últimamente se escriben algunas novelas, sobre todo de feministas americanas, que hablan de ello: de vida-tristeentre-el-fontanero-pañales-supermercado-ganchillorecetas de cocina'. Por lo menos parten de ello, pienso en Mujeres $y$ en Cuestiones candentes. Así, parece claro que es necesario este primer paso hacia la creación de un universo autónomo. El paso previo para trascender la autobiografía, la literatura de confesión. (p.163)

Criar um universo autônomo, que vá além da autobiografia, é algo possível quando a escritora, já madura no campo das ideias, entende seu lugar como mulher e como criadora. Assim, para alcançar a autonomia proposta, é preciso se apropriar da linguagem e das formas literárias, 
traduzindo a sua perspectiva em literatura. "La forma es lo que convierte cualquier tema en "universal" (p. 164), diz a autora: os temas cotidianos, da intimidade ou sentimentais, podem para Roig, ser transformados em boa literatura, ainda que para muitos pareçam menores.

A escrita feminina reflete a forma como a mulher interage com o mundo. Se está muito mais circunscrita ao espaço doméstico, esse será retratado por ela. Mas ao pensar em uma realidade que envolve cuidar dos filhos, da casa e de toda a rotina envolvida, quando é que a mulher terá tempo para escrever, para buscar a melhor forma e linguagem para representar um tema literariamente, pergunta-se Roig. A autora retorna aos questionamentos colocados no início do ensaio, demonstrando como os argumentos se entrelaçam.

O caso é que por mais que tenhamos conquistado alguns direitos, as mulheres ainda acumulam junto às atribuições do espaço público, com o trabalho ou o estudo, as funções domésticas e a maternidade. Mencionando que Virgínia Woolf, que tinha uma renda (que não lhe fazia ter de trabalhar) e que não teve filhos, dizia que o latido dos cachorros incomodava aos escritores, Roig demonstra como é difícil para a mulher moderna poder se dedicar à escrita.

Para Montserrat Roig todo artista deve ter um "útero" que o proteja dos problemas da vida comum para poder criar. Essa metáfora representa um espaço de proteção que lhe permita se dedicar totalmente à sua obra e, no caso de artistas homens, esse útero é muitas vezes constituído por uma companheira, companheiro ou pessoa próxima que se encarrega das futilidades cotidianas, preservando o artista. No entanto, a autora destaca que em muitos casos esse tipo de proteção não se aplica às mulheres artistas, que têm de 
arcar com todas as atividades do dia a dia sozinhas, "como si fueran las proletarias dentro de la jerarquia literaria” (p. 165).

Roig encerra o ensaio alegando que a produção artística da mulher estaria em uma encruzilhada, buscando ainda definir o seu rumo. Para ela, muitas questões podem ser propostas ao pensar no súbito ingresso das mulheres no universo da cultura, como, por exemplo, "iqué pasará si proponemos nuevas dudas ante los grandes enigmas como bacen los hombres artistas? ¿significará que empezará la pérdida de la inocencia? ¿la corrupción? [...] ¿Olvidaremos la vida para hacer arte? [...] ¿seremos Beethoven y Hitler?’ (p. 166). A dúvida que se destaca está associada ao fato de que é algo novo contar com tantas mulheres produzindo conhecimento e arte. Não se pode definir como a Cultura, com maiúscula, como escreve Roig, reagirá a uma transformação como essa.

A tradição cultural estabelecida a partir de valores patriarcais precisa receber e se adaptar a um cenário em que mulheres escrevem, pesquisam, produzem saberes. Essa adaptação, porém, ainda está em processo. Não se sabe como serão os próximos anos, vemos, a cada dia, mais mulheres se inserindo no universo acadêmico e cultural, muitas vezes lidando com preconceitos e com as dificuldades advindas do acúmulo de atividades de trabalho, maternidade e organização doméstica.

Por outro lado, a inserção da mulher na Cultura e na produção de saberes, pode significar também uma mudança nesse paradigma, levando a uma mudança no próprio olhar sobre si:

Si dejamos la casa, el mundo cotidiano, nos vamos a sentir tan desvalidas que nos sublimaremos en el arte, como hacen los hombres-artistas. Tendremos que dominar, también, para disimular ante el mundo de fuera, cruel y despiadado, como bacen los 
hombres. Y me parece que se acerca el momento en que nos sublimaremos a través del arte y la cultura porque nos empezamos a dar cuenta que la infelicidad no significa masoquismo ni resignación, sino que forma parte de la misma condición bumana. Abi está la ambivalencia: la pérdida de la inocencia conlleva la necesidad de creación. Es fascinante y aterrador al mismo tiempo. (p. 166)

Ocupar novos espaços sociais e ter novas perspectivas no âmbito da vida doméstica, levaria a uma aproximação da mulher aos contextos em que homens produzem arte ou outros tipos de saberes, eliminando as limitações que encontra ao ter de assumir filhos, casa e família, ao mesmo tempo em que busca se dar atenção aos seus interesses criativos, e permitindo-lhe gozar da mesma possibilidade de dedicação artística que os homens. Estaria aí a perda da inocência que menciona Roig: a dedicação integral à arte ou ao conhecimento, distanciada da vida comum, provocaria um outro olhar sobre o trabalho intelectual das mulheres.

\section{ALGUMAS CONSIDERAÇÕES}

A leitura do ensaio de Montserrat Roig possibilita uma aproximação ao pensamento feminista que se difundia no final do século XX. É possível notar como a produção de algumas intelectuais feministas fazem eco no trabalho da escritora catalã, que dialoga com diferentes interpretações do lugar social da mulher, de sua relação com a criação intelectual e com as dificuldades impostas àquelas que se aventuram pela produção de conhecimento.

Essa relação intertextual que se projeta sobre todo o ensaio parece estabelecer uma teia de argumentos, conectando diferentes perspectivas e revelando como Roig é, ela também, 
uma intelectual que se interessa em se aprofundar no debate que se produzia e em elaborar reflexões sobre ele. Nesse sentido, não seria um equívoco aproximar esse tipo de escrita intertextual da proposta de Thiphaine Samoyault (2008), de entender essas relações como um exercício de memória da escritura. Ela comenta que:

As práticas intertextuais informam sobre o funcionamento da memória que uma época, um grupo, um indivíduo têm das obras que os precederam ou que lhes são contemporâneas. Elas exprimem ao mesmo tempo o peso desta memória, a dificuldade de um gesto que se sabe suceder a outro e vir sempre depois (SAMOYAULT, 2008, p. 68).

Esse texto que recupera outros discursos, ativando a memória de outros textos, outras vozes que se aventuraram a discutir a ausência de mulheres geniais do contexto de produção de saberes, permite a construção de uma tela elaborada e cheia de matizes. O diálogo que estabelece a autora com essas outras vozes, dá ao ensaio um formato espiralado, no qual se retomam temas antes discutidos e se avança rumo a argumentos que os associam a outros. Embora pareça que a escrita de Roig se repete, o que se percebe é que um mesmo assunto vai sendo discutido e aprofundado sob diferentes perspectivas.

O formato em espiral desse ensaio é presente em outras obras de Roig, tanto literária, como jornalística. A espiral talvez seja a forma adotada pela escritora para dar expressão à sua própria voz. Seja por trazer um parentesco com a oralidade, seja por possibilitar a aproximação a um tema de maneira a não só desenvolvê-lo, como também conectá-lo a outros prismas, a escolha da autora revela muito sobre si e seu estilo como escritora. É como se a voz que 
constitui o texto representasse uma conversa de mulheres, um colóquio despretensioso entre amigos, que conquista e envolve o leitor.

Outrossim, o recurso narrativo que se imprime no diálogo com o intelectual francês é utilizado, já nas primeiras linhas do texto, para conquistar o leitor, que se sente, a princípio, em contato com uma narrativa, ao invés de um ensaio. O plano argumentativo do texto é inserido sem que o leitor perceba: ao invés de uma anedota, o que se revela é um olhar sobre a história da exclusão feminina da ciência e da literatura e a discussão dos mecanismos dessa exclusão dos espaços intelectuais.

O discurso apresentado é composto por um tom coloquial, além de ser carregado de exemplos com os quais o leitor pode se identificar. A linguagem simples facilita a apresentação de argumentos retirados da antropologia, da filosofia, dos estudos feministas e da crítica literária. Nota-se que o ensaio de Roig não se pretende acadêmico, mas um texto acessível ao leitor leigo ou não.

Assim, o leitor inexperiente pode não reconhecer os diálogos que o texto de Roig estabelece com diferentes pensadoras de seu tempo, mas é capaz de compreender os argumentos propostos. Já o leitor experiente, reconhece a intertextualidade e observa os recortes, conexões e discussões que estabelece a escritora catalã. O importante, para a autora, parece ser alcançar diferentes públicos e levar a eles a discussão sobre o lugar da mulher na produção do conhecimento.

Essa ideia de alcançar públicos diversos ganha mais notoriedade ao se considerar que alguns dos argumentos desse ensaio são apresentados em outros textos de Montserrat Roig, em gêneros e mídias diferentes. Em primeiro lugar,

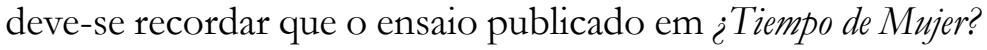


já tinha sido publicado antes na revista Vindicación Feminista, em 1977, com o mesmo título. Nesse caso, o artigo, que chegou a estampar a capa da revista que era vendida em bancas de jornal, poderia alcançar um público extenso, não necessariamente aquele interessado em um livro de ensaios. Outro caso é o do romance L'hora violeta (1980), que recupera o diálogo apresentado no começo do ensaio. Nesse caso, são os leitores interessados em literatura os alcançados. Por fim, nota-se uma conexão entre o ensaio e um apartado da obra Digues que m'estimes encara que sigui mentida (1991), obra dedicada aos leitores da obra da autora e aos que se interessam pelo processo de escrita literária, pela teoria e pela crítica da cultura. O apartado La mirada bòrnia, discute, em dois ensaios, "L'un i l'altra" e "Del 'ja no' a 'l'encara no" "4, alguns dos argumentos apresentados aqui.

Quatro publicações diferentes, com diferentes públicos leitores permitiram que as ideias veiculadas no ensaio ¿Por qué no ha habido mujeres genio? circulassem entre grupos sociais e etários diferentes. Esse amplo alcance entre os públicos pode ser entendido como uma tentativa de contribuir para ampliar os debates relacionados à mulher e à literatura, levando as discussões acadêmicas para outros espaços, socializando-as.

Os argumentos do ensaio trilham um percurso que contesta as ideias popularmente transmitidas sobre a capacidade intelectual feminina, desde aquelas que se centram na biologia da mulher, até a existência de uma suposta acomodação feminina ao espaço doméstico, que lhe tomaria por completo e impediria que se interessasse por atividades outras. O lugar social destinado à mulher é ressaltado como o principal motivo de sua ausência dos registros e da vida pública e intelectual.

4. "O uno e a outra" e "Do 'já não' ao ‘ainda não" " 
A proposta de uma arqueologia da história das mulheres surge como um intento de recuperar a memória das mulheres comuns e das que se destacaram por seus talentos, colaborando para a constituição de uma identidade e de uma tradição. Mas além de conhecer a história das que a antecederam, a mulher precisa encontrar uma voz para se expressar. No caso da escritora, sua voz está associada com sua perspectiva, com o que tem a dizer, mas também com a forma como dizer. A forma como se utiliza a linguagem é essencial, já que a partir dela é possível tratar de qualquer assunto literariamente.

Os argumentos de ¿Por qué no ha habido mujeres genio? apontam para uma mudança no paradigma que tivemos sobre a mulher durante muito tempo. Em um momento em que cada vez mais mulheres conquistam uma voz própria é preciso rever valores socioculturais para inseri-las e integrálas a um âmbito antes dominado pelo patriarcado. Não há respostas que antecipem como a produção intelectual de mulheres será entendida no futuro: ainda estamos vivendo o processo de transformação.

\section{REFERENCIAS}

BEAUVOIR, Simone. E1 segundo sexo. Trad. Alicia Martorell. Madrid: Cátedra, 2013.

CABRÉ, Ma Ángeles. Leer y escribir en femenino. Barcelona: Aresta, 2013.

COLOMINA DE RIVERA, Marta. La Celestina mecánica: estudio sobre la mitología de lo femenino, la mujer y su manipulación a través de la industria cultural. Caracas: Monte Ávila Editores, 1976.

DUPLÁA, Christina. Montserrat Roig: mujeres, genealogía y lengua maternal. In: VOLLENDORF, Lisa (ed.). Literatura y feminismo en España (s. XV-XXI). Barcelona: Icaria, 2005. p. 305-321.

DUPLÁA, Christina. La voz testimonial en Montserrat Roig: estudio 
cultural de los textos. Barcelona: Icaria Editorial, 1996.

MILLET, Kate. Política sexual. Trad. Ana María Bravo García. Madrid: Cátedra, 2010.

OLIVEIRA, Rosiska Darcy de. Elogio da diferença: o feminino emergente. Rio de Janeiro: Rocco, 2012.

PERROT, Michelle. História (sexuação da). Trad. Vivian Aranha Sabola. In: HIRATA, Helena; LABORIE, Françoise; LE DOARÉ, Hélène; SENOTIER, Danièle (orgs.) Dicionário Crítico do feminismo. São Paulo: Editora UNESP, 2009. p. 111-116.

ROIG, Montserrat. La mirada tuerta. In: ROIG, Montserrat. Dime que me quieres aunque sea mentira. Sobre el placer solitario de escribir y el vivió compartido de leer. Barcelona: Península, 2001.

ROIG, Montserrat. El feminismo. Barcelona: Salvat Editores, 1986.

ROIG, Montserrat. L'hora violeta. Barcelona: Edicions 62, 1981.

ROIG, Montserrat. ¿Por qué no ha habido mujeres genio? In: ROIG, Montserrat ¿'Tiempo de Mujer? Barcelona: Plaza y Janés, 1980. p. 145166.

ROIG, Montserrat. ¿Por qué no ha habido mujeres-genio? In: Vindicación feminista: Una voz colectiva, una historia propia. Antología facsímil de textos (1976-1979). Zaragoza: Prensas Universitarias de Zaragoza, 2009. (DVD). Número 18, diciembre de 1977, p. 24-28.

SAMOYAULT, Thiphaine. A intertextualidade. Trad. Sandra Nitrini. São Paulo: Aderaldo \& Rothschild, 2008.

SHOWALTER, Elaine. A literature of their on: British women novelists from Brontë to Lessing. Princeton: Princeton University Press, 1977.

WOOLF, Virginia. Um teto todo seu. Trad. Bia Nunes de Sousa; Glauco Mattoso. São Paulo: Tordesilhas, 2014.

ZINANI, Cecil Jeanine Albert. História da literatura: questões contemporâneas. Caxias do Sul: Educs, 2010.

ZOLIN, Lúcia Osana. Literatura de autoria feminina. In: BONNICI, Thomas; ZOLIN, Lúcia Osana (orgs.). Teoria literária: abordagens históricas e tendências contemporâneas. Maringá: EDUEM, 2009. P. $327-$ 336. 


\title{
CAPÍTULO 9
}

\section{LA MUJER OUE SE LEE EN “A COSTA DOS MURMÚRIOS”, DE LIDIA JORGE}

\author{
Adriana Esther Suarez (UNCuyo) \\ "Prefere a harmonia? Eu também, épor isso que tanto \\ estimo a paz, que se respira na noite d'Os gafanhotos" \\ (Lídia Jorge)
}

Una destacada característica de la literatura ha sido desde siempre mostrar cómo la sociedad, con el apoyo de las distintas formas de gobierno y religiones, relegó a la mujer a roles secundarios dentro de la participación social. No obstante, ella encontró una brecha para observar el mundo androcéntrico a través de la lectura. Esta fue la posibilidad de quebrar los esquemas de la cultura y la tradición patriarcales. Por un lado, la lectura de textos literarios fue para la mujer una ventana al mundo del que se había adueñado el hombre, una pequeña fisura para acceder de alguna manera al conocimiento, a la libertad y a la vida misma. Más tarde, por otro lado, la literatura logró también representar ese universo femenino de lectoras pasivas.

La mujer lectora, según Espósito (2006), fue el verdadero emblema de la novela europea decimonónica. El 
autor diferencia en su artículo tres tipos: la lectora adúltera, la enferma y la independiente. La primera es la consumidora de libros mundanos que divulgan los ideales de la vida moderna. Es la que deja de lado los mandatos sociales en busca de nuevas sensaciones y emociones. La segunda es la lectora que padece la fascinación por una literatura popular imposible de controlar. Y la tercera, la independiente, es la que desprecia la lectura pasional y coloca en destaque la capacidad de análisis de la mujer inteligente, que sabe hacer una lectura crítica tanto de textos como del mundo. Eso era lo que las diferenciaba, sin embargo, los tres tipos de mujeres lectoras se igualaron en la peligrosidad con que fueron interpretados. Se trataba del temor de despertar conciencias hasta ese momento consideradas dormidas.

También Bollmann (2006) ha estudiado, a través de la pintura, los patrones de comportamiento de la mujer lectora desde la Edad Media hasta nuestros días. Su obra defiende la lectura femenina que injustamente fue censurada por el patriarcalismo, que la tildó de arma o herramienta emancipadora y reivindicadora de los derechos de la mujer. Al respecto, Tusquest (2006, p.15) recuerda que durante siglos las mujeres lectoras fueron sospechadas de futuras rebeldías, ya que los libros podían llegar a minar una cualidad fundamental en ellas: la sumisión.

Bollmann distingue la gran diferencia que existe entre la lectora decimonónica y la del siglo XX. Esta última sería la que busca en los libros las respuestas a preguntas esenciales de la vida (2006, p. 108). Varios tipos de estas lectoras fueron representados por la literatura. Una de las primeras en ser mencionada por la crítica literaria es Emma Bovary, el inolvidable personaje de Flaubert. Su equivalente en la literatura portuguesa es Luísa de O primo Basílio de Eça de 
Queiros. Ambos autores apuntaron con vehemencia los vicios que habían aparecido en la sociedad europea de sus épocas con especial relevancia a lo que hacía a la educación femenina. En la literatura argentina, un ejemplo de lectora romántica es Amalia de la obra homónima de José Mármol. Estos son algunos de los personajes femeninos influenciados por la lectura, entre muchos más.

Algo no común de encontrar entre los personajes de lectoras del siglo XIX y XX es el de alguna que leyese un texto sobre su propia vida, o acontecimientos de los que habría sido protagonista. Mucho más inconcebible, si se tratara de una lectora que discutiese con el narrador de un relato y generara cuestionamientos sobre la dicotomía realidad/ficción en el texto leído.

Este artículo apunta a abordar la presencia del personaje femenino Eva Lopo que en la novela $A$ costa dos murmúrios (1988) de la autora portuguesa Lídia Jorge representa una lectora diferente del siglo XX. En nuestro análisis intentamos demostrar cómo ella se aleja totalmente tanto de las lectoras decimonónicas presentadas por la literatura de esa época como de sus contemporáneas. A partir de ello, intentamos resaltar el juego de miradas que hay en la obra, lo que la convierte en una suerte de contraste efectivo con el rol de la mujer lectora de las novelas de los siglos XIX y XX.

\section{LECTURA Y MEMORIA}

La novela $A$ costa dos murmúrios gira en torno a la lectura que el personaje Eva Lopo hace de un cuento, "Os Gafanhotos". El texto narra hechos que acontecieron en su pasado cuando ella era una joven a la que llamaban "Evita". Eva es una mujer que, en los años 90 del siglo XX, está 
leyendo sucesos ocurridos en un Mozambique, todavía colonia portuguesa, donde ella había residido veinte años antes.

La obra está dividida en dos partes, una inicial que pertenece al género cuento, "Os Gafanhotos" (JORGE, 1988, p.9-39), y la novela propiamente dicha que abarca del capítulo I al IX (JORGE, 1988, p. 41-259), dejando al mencionado cuento en un lugar diferente del resto de la obra. Los dos géneros están entrelazados en relatos íntimos compartidos. El primero, narrado en tercera persona por un narrador omnisciente, presenta fragmentos del casamiento y corta vida en pareja de Evita, una joven portuguesa que había viajado a Mozambique para casarse con su novio, el alférez Luís Alex. Esto tendrá como telón de fondo la guerra por la independencia del país africano ${ }^{1}$. El segundo, la novela propiamente dicha, cuenta con una narradora en primera persona, Eva Lopo, quien discute con el narrador del cuento la autenticidad de ese escrito que está leyendo.

El recurso del cuento introductorio a la novela habilita una relación dialéctica entre dos sujetos narradores diferentes que compartieron la experiencia colonial mozambiqueña en época y espacio. Eva Lopo, al mismo tiempo que lee, se dirige al narrador del cuento como si fuera su interlocutora, en un diálogo imaginario en segunda persona. De esa forma, aparecerán imperativos como "repare" (p. 129); "Deixe-se disso" (p. 143); "Deixe ficar aí" (p. 259). Así como también consejos o sugerencias: Aconselho-o" (p. 42); "Você poderia [...] (p. 193); "Como vê" (p. 258), entre otros.

1. La guerra por la independencia de Mozambique estalló en 1964 y fue como resultado del malestar de la mayoría de la población nativa, que veía al gobierno colonial portugués como invasor despótico. El país logra la independencia en 1975 después de la revolución de los Claveles que derribó la dictadura en Portugal y con ello su política colonialista. 
Después de la correspondiente lectura, Eva comienza a comentar aquella narración, especialmente para criticarla. La novela se convierte en una diatriba contra el narrador de "Os Gafanhotos", discurso en el que habrá momentos de pequeños reconocimientos de la memoria acerca de lo leído, aunque inmediatamente fueran anulados con ironía. Ella lee haciendo cotejos entre el relato que tiene frente a sí y sus recuerdos.

Eva le menciona constantemente al narrador que fueron y estuvieron juntos en la misma ciudad (BeiraMozambique), así como también le recuerda algunos hechos de los que fueron testigos. Desde ese lugar va a posicionarse para leerlo: "A si, a mim, que fomos onde fomos, estivemos onde estivemos..." (JORGE, 1988, p. 43). Aunque el narrador se presenta como un interlocutor que no responde, se convierte en la figura en la que se vuelcan comentarios y recriminaciones de Eva Lopo como lectora crítica.

Hay dos temas fundamentales en la obra: lectura y memoria, que se concretan generalmente en contrapunto. La lectura que hace Eva Lopo, como testigo de los hechos narrados y filtrados por su memoria, está llena de detalles.

Acabada la lectura de "Os Gafanhotos", Eva no hace comentarios acerca de los graves sucesos de la ocupación colonial, de la guerra, ni de lo que sería lo más importante, la muerte de su marido. Ella se detiene en minucias de aromas y sonidos, en la rapidez en que la fruta se descomponía con el calor mozambiqueño, en el sonido del mar. Esos pormenores les restan preponderancia a los hechos que serían leídos posteriormente. Los detalles, afirma Beatriz Sarlo, aportan un "dispositivo de prueba" (2007, p.71), como si la verdad de lo narrado estuviese en ellos y fuesen conocidos por el narrador que estuvo en el lugar de los acontecimientos. 
Con relación a los detalles en los relatos testimoniales, Sarlo agrega que aunque parezcan insignificantes, si son repetidos, se adecuan mejor que la proliferación de datos. Igualmente, cualquier suma de detalles no hará que historia alguna quede completa o sea veraz, simplemente podrá interferir en lo que respecta a su verosimilitud (SARLO, 2007, p.72). Sin embargo, la exactitud y lo verdadero que en materia de aromas y sonidos Eva Lopo reconoce son también ironías de una lectora crítica. En realidad, en el cuento no se mencionan olores ni fragancias. Tampoco es importante la referencia a sonidos, salvo comentarios sobre la música de la orquesta del hotel Stella Maris, donde paraban los militares portugueses y sus familias.

El narrador del cuento, por su parte también irónico, hace un uso exacerbado del recurso de la descripción de colores y formas del entorno africano: "As lagostas vermelhas e abertas", "As papaias amarelas...cortadas em feitio de coroa de rei"; "Um criado extraordinariamente negro, vestido de farda completamente branca"; (JORGE, 1998, p.10). Continúa así, remarcando con insistencia la importancia de tonos y colores: "instrumentos ...tocados por quatro brancos e um negro"; "o Sol estava bem amarelo"; "Beira...tão amarela quanto o ananás e a papaia" (JORGE, 1998, p.11). La descripción del color local se encuentra a lo largo de todo el cuento. Eva finge concordar con el texto, sin embargo, opone "aromas y sonidos" a los "colores y formas" presentados por el narrador.

Siguiendo los presupuestos teóricos del narrador omnisciente de Todorov ${ }^{2}$, ella comenta:

2. Con respecto al narrador omnisciente, Todorov afirma que "...no tenemos derecho a preguntarnos si eso (el relato del narrador omnisciente) es falso o verdadero; semejante pregunta no tiene sentido" (2003, p.68). En tanto narrador, afirma Todorov, su discurso no debe ser sometido a la prueba de la $\operatorname{verdad}(2003$, p.69). 
Esse é um relato encantador. Li-o com cuidado e concluí que nele tudo é exacto e verdadeiro, sobretudo em matéria de cheiro e de som - disse Eva Lopo. Para o escrever desse modo, deve ter feito uma viagem trabalhosa a um tempo onde qualquer outro teria dificuldade em regressar. Pelo que me diz respeito, o seu relato foi uma espécie de lamparina de álcool que iluminou, durante esta tarde, um local que escurece de semana a semana, dia a dia, à velocidade dos anos. Além disso, o que pretendeu clarificar clarifica, e o que pretendeu esconder ficou imerso (JORGE, 1988, p.41).

De la cita anterior se desprende que Eva Lopo no tiene la pretensión de hallar en el cuento la transparencia esperada en un relato realista. Con el término "transparencia" nos referimos al concepto de Byung-Chul Han, que lo define como el uso de todas las leyes de la lingüística formal para mencionar cada objeto y cada acción. Según el filósofo, con la transparencia la narratividad se pierde con el exceso, entorpece la comprensión y "también la memoria queda afectada por ello” (HAN, 2018, p. 63). La memoria de Eva Lopo rechaza la verbosidad, realiza la construcción de su propia narratividad y la distingue de la acumulación de palabras criticada por Han en los discursos (2018, p. 64).

Eva sabe que el paso del tiempo, entre otros motivos, puede modificar los recuerdos y lo reconoce al afirmar: "Convenhamos que me lembro imperfeitamente, o que não deve ter nenhum significado secundario" (JORGE, 1988, p. 127). Ella, como lectora, distingue los temas principales de los secundarios. Sabe diferenciar los hechos veraces encubiertos en el cuento.

Eva es consciente de que la narración del cuento ejecuta una selección, ya que no puede nombrarlo todo. 
Dicho recorte será importante siempre que los lectores, representados en este caso por ella, encontremos en el texto indicios que se correspondan con conocimientos previos.

Los hechos relatados en el cuento provocaron en Eva Lopo el quiebre del hilo del discurso acerca de discusiones sobre historia y memoria e hizo que ella lo llevara hacia el campo de la "correspondencia". Esto se pone de manifiesto cuando tranquiliza al narrador diciéndole: "Aconselho-o, porém, a que não se preocupe com a verdade que não se reconstitui, nem com a verossimilhança que é uma ilusão dos sentidos. Preocupe-se com a correspondência" (JORGE, 1988, p. 42).

Desde ese lugar, establece un diálogo con el narrador como segunda persona y le cuestiona si realmente "acredita noutra verdade que não seja a que se consegue a partir da correspondência" (JORGE, 1988, p. 42). El hecho de coincidir en espacio y tiempo de ambos narradores como testigos de hechos inenarrables es suficiente para que rechacen la idea de seguir un texto realista como espejo del mundo. Con esa idea no realista de escritura y lectura, Eva sugiere evitar una historia creada por un "espírito preocupado com a inteligência e a verdade, quando tudo - julgava-se - refletia em tudo como uma amostra, um espelho e um reflexo" (JORGE, 1988, p. 42).

Para Eva se trata de otra cosa, que tiene que ver con correspondencias y coincidencias. Así, tomó como ejemplo la descripción realizada del mayor del ejército y felicitó al narrador por los detalles resaltados. Aunque Eva nunca había conocido al mayor, afirmó que "correspondía" a la figura de su propio padre. Le confirmó al narrador haber reconocido los dientes del mayor en otra boca, el látigo en otras manos y los cabellos en otra cabeza. 
Además de las descripciones físicas, habrá también un juego con la forma en que los militares se dirigían a las mujeres. El narrador hizo que el comandante de la región llamase a las damas portuguesas de "Mesdames" y, más tarde, que el mayor también saludase a Evita como "madame" .

Esa forma de nombrarlas, tanto del comandante como del mayor, será rebatida por Eva: "Madame...era um sussurro que saía com frequência da boca do Gerente de Messe que não tinha nada a ver nem com a testa nem com o pingalim" (JORGE, 1988, p. 43). Con ello se refiere a la cabeza, dientes y el látigo, mencionados anteriormente, detalles esos que se encontraban presentes en diferentes personajes guardados en su memoria.

La lectora vuelve a remarcarle a su interlocutor la importancia de las correspondencias por encima de los hechos reales de la historia y la memoria al cuestionarle: “...por que insiste em História e em memória, e ideias dessas que tanto inquietam? Ah, se conta, conte por contar, e é tudo o que vale e fica dessa canseira" (JORGE, 1988, p. 62). Eva Lopo defiende la escritura por correspondencias porque como lectora elige la narración en sí por sobre los acontecimientos reales guardados en su memoria de testigo presencial de los hechos ocurridos en Mozambique.

A costa dos murmúrios es una novela memorialista, de una memoria de lo vivido, que se sabe ignorado por la historia hegemónica y se activa con la lectura del cuento.

3. "Oh! Oh! A guerra! Se não fosse a guerra, mesdames, até a calmaria criaria pedra!" (JORGE, 1988, p. 13).

4. "Madame, os meus respeitos!" (JORGE, 1988, p. 39). 


\section{LA FUNCIÓN DEL TEXTO}

En lo que hace a ambos textos, nosotros somos tanto lectores del cuento "Os Gafanhotos" como de la interpelación de otra lectora. Así, nos llegan ambos por igual, de una misma variante del portugués de Portugal, en la que los dos priorizan la claridad de términos y expresiones. Sin embargo, hay indicios de que esas narraciones de vida tengan estilos distintos y una propuesta de escritura/lectura diferente.

El idioma que aproxima los dos relatos no fue elegido por sus autores, sino que les fue dado por "naturaleza" (BARTHES, 2003, p.17). Al leerlos bajo el análisis barthesiano, también podemos decir que difieren en estilo, siendo, sin embargo, algo que ellos tampoco escogieron. El estilo, según Barthes, "es un fenómeno de orden germinativo" (BARTHES, 2003, p.21), cuyas alusiones están distribuidas en la profundidad del texto. Así como la lengua está en la superficie, en la horizontalidad del escrito, el estilo se halla en lo que lo atraviesa verticalmente. "El horizonte de la lengua y la verticalidad del estilo dibujan pues, para el escritor, una naturaleza, ya que [el autor] no elige ni el uno ni el otro" (BARTHES, 2003, p. 21). De esa forma, el autor de "Os Gafanhotos" relata una historia que pudo haber presenciado en parte y posteriormente trabajado en la lengua y el estilo. En oposición, Eva Lopo narra desde un estilo aprehendido de sus experiencias de vida, de su estancia en el lugar de los hechos, de sus propias lecturas de mundo. "Lengua y estilo son el producto del Tiempo y de la persona biológica", afirma Barthes (2003, p.21).

Pero en lo que realmente difieren los textos de aquellos dos narradores es en la elección que cada uno de ellos hace de una noción de escritura/lectura como función social que quieren darles a sus narraciones. Las nociones de escritura a 
las que se refiere Barthes muestran "la reflexión del escritor sobre el uso social de su forma y la elección que asume" (2003, p.23).

A su vez, ambos textos se igualan al presentar entre comillas largos párrafos en discurso directo. Sin embargo, en "Os Gafanhotos" remiten principalmente al habla de los militares y sus esposas y en los elegidos por Eva Lopo prevalecen los enunciados de tipo personal. En el cuento, existe la necesidad de denunciar la política central y las acciones llevadas a cabo por el ejército, mientras que en la lectura de Eva Lopo, más intimista, hay una urgencia por mostrar lo que la guerra hace con las personas.

En lo que sí se igualan los recortes de discurso que los narradores realizan es en la ironía y en la férrea crítica al sistema colonial. Vemos, en la primera parte de "Os Gafanhotos", como el comandante de la región, máxima autoridad, que gozaba de la admiración de todos sus subordinados y de las esposas de estos, comentaba:

As pessoas têm de África ideias loucas. As pessoas pensam, minha senhora, que África é uma floresta virgem, impenetrável, onde um leão come um preto, um preto come um rato assado, o rato come as colheitas verdes, e tudo é verde e preto. Mas é falso, minha senhora, África, como terá oportunidade de ver, é amarela. Amarela-clara, da cor do whisky! (JORGE, 1988, p. 11-12)

Más tarde, ante el final trágico de los personajes, el mismo comandante, acercándose a la playa donde yacía el cuerpo muerto del alférez, le dijo a Evita: "Por vezes, África deixa de ser amarela da cor do scotch para ser de variegadas cores ...Sorry, sorry..." (JORGE, 1988, p.38). 
Los comentarios improcedentes, podría aun decirse vacíos, sobre los colores de África son parte del discurso del comandante tanto en una fiesta de casamiento como ante la muerte de uno de sus hombres. Los fragmentos del discurso del habla del personaje escogidos presentan un patrón de enunciado que no transmite nada.

La elección que el narrador del cuento realizó sobre el habla del comandante no fue aleatoria. Los recortes ponen en evidencia lo irrisorio del habla del personaje al dotar a ciertos colores de los significados fundamentales de África. Él escogió y recortó el discurso para darle el uso deseado. La ironía con que el cuento presenta las palabras del comandante ante los invitados incita a una lectura condicionada por la burla y va politizando el relato, cartografiándolo, territorizándolo.

En dichos recortes se destaca lo inoportuno del discurso, principalmente ante la muerte, del supuesto hombre más importante del ejército portugués con asentamiento en Beira. Esto no sólo rebaja al personaje, sino que lo hace extensivo a toda la fuerza militar.

También Eva Lopo, a su vez, introduce con discurso directo un comentario de Helena, esposa del capitán Forza Leal, sobre los soldados que estaban luchando en el norte mozambiqueño. La forma en que ella sólo contaba como bajas las de los portugueses denota insensibilidad con respecto al otro:

Enfim» — disse ela. «Cinquenta baixas só é muita baixa quando se pensa no luto de cinquenta famílias, nos sinos, nas salvas, nas tumbas - fico em carne de galinha quando penso nas tumbas. Mas não é nada, absolutamente nada, quando se imagina que vai terminar uma rebelião armada que tem ceifado inocentes de todas as cores 
apenas com cinquenta baixas! (JORGE, 1988, p. 95)

Al mismo tiempo, esa fingida preocupación cae por tierra cuando al cortar abruptamente el tema de los muertos realiza el remate del diálogo con una curiosidad puntual acerca de la preferencia de Evita de seguir viviendo en el hotel Stella Maris, destinado a los militares: "[...] — disse Helena. "Você fez mal em não ter aproveitado a casa. Porque não aproveitou a casa?” (JORGE, 1988, p. 95), refiriéndose a las viviendas abandonadas por los colonos, que habían huido descreídos de la victoria lusitana. Eva remarca con ese recorte la insensibilidad de Helena, en primer lugar, por los nativos africanos y, finalmente, por sus compatriotas, cuyas vidas (muertes) mide con la importancia de una cifra.

Mucho más preocupante para Eva fue recordar el cambio que se había operado en aquel tiempo en su flamante marido, el alférez Luís Alex. En cierta ocasión, al llamarlo con el nombre de un reconocido matemático, él le había hecho saber que la broma de compararlo con "Évariste Galois" no era de su agrado:

Ele perguntou-me — "Angustia-te?"

Eu respondi - "De modo nenhum". E como a nossa compreensão ainda era perfeita, acrescentei — "De modo nenhum, Évariste Galois!” O noivo deixoume escorregar por si abaixo. "Não me chames isso» — disse ele. "Já lá no terraço me chamaste isso e eu me calei, mas agora digo-te que nunca mais quero que me voltes a chamar Evaristo Galois!"

"Gostavas".

"Nunca gostei, mas suportava, só que não quero suportar de novo" - disse ele, com os olhos muito abertos e muito escuros. 


\begin{abstract}
"Nunca pedi a ninguém que me chamasse essa anomalia de nome". Sentou-se com as mãos nos joelhos, com os lábios unidos, as comissuras tensas. Mas não valia a pena explodir se não queria que lhe voltasse a chamar Evariste Galois (JORGE, 1988, p. 46).
\end{abstract}

El diálogo, que antecede, dice todo acerca del cambio que se produjo en la personalidad de un joven estudiante de matemáticas que fue a la guerra en las colonias africanas. El novio de Evita había sido transformado por el conflicto bélico. Ese recuerdo de la intimidad de Eva Lopo, que vuelve a su presente, es en apariencia inocente. Sin embargo, remite a los cambios sufridos por un ciudadano portugués que tuvo que alistarse (o que quiso hacerlo) en el ejército y enfrentar la guerra colonial. El joven alférez negaba su vida como civil, aun anulándola al no desear que se la mencionasen.

Otro detalle que llama poderosamente la atención de Eva Lopo es la parte del cuento que describe la cicatriz del capitán Forza Leal, quien aparece en el hall del hotel Stella Maris "com a camisa aberta sobre a nesga da cicatriz" (JORGE, 1988, p.23). La lectora encuentra en esa descripción "um dos pontos comoventes d'Os Gafanhotos" (JORGE, 1988, p.63) y reconoce que llegó a ver la famosa herida del capitán y la recordaba claramente.

Aunque Eva acepta el detalle de la cicatriz del capitán como dato real, lo hace simplemente para llevarlo al tema de su intimidad. Reconoce que esa marca de virilidad seducía por igual a hombres y mujeres, que el capitán lo sabía y acentuaba usando camisas trasparentes, generalmente sin abotonar, o insistiendo en ir a nadar y poder así quitarse la ropa (JORGE, 1988, p. 66). 
El alférez Luís Alex, como gran admirador de Forza Leal, le atribuía a la cicatriz un "significado tão amplo" (JORGE, 1988, p. 63) que para Evita era imposible abarcar. $\mathrm{Al}$ escuchar a su novio describir la herida del capitán y cómo se había producido el ataque enemigo, le hacía imaginar que este era el "último homem do século que se revisse na sua cicatriz" (JORGE, 1988, p. 63). No obstante, esa visión sería transformada hasta la negación por el pasar del tiempo. Desde su madurez, Eva sostiene que las únicas marcas válidas de admiración eran las conseguidas "enquanto se lutou com uma arma de lâmina" (JORGE, 1988, p. 63). Veinte años después, al momento de la lectura ella reflexiona y afirma que ya "desapareceu o significado das cicatrizes de guerra que se confundem completamente com os sinistros de estrada" (JORGE, 1988, p.64).

Innúmeras son las oportunidades en que fragmentos de discurso directo se recortan con ironía o crítica al sistema sociopolítico-militar. Así, tanto en lo que hace al ejército como a las familias portuguesas, los fragmentos elegidos develan la decadencia del poder hegemónico. Sin embargo, el narrador pone el foco en el poder, llámese gobierno y militares, y Eva apunta a las consecuencias sufridas por los civiles.

En otra perspectiva, el ejercicio de la memoria estará además mediado por la ideología de los narradores, que será fundamental para entender en el discurso la noción de escritura/lectura a la que hace referencia Barthes y que fue mencionada anteriormente.

Eva Lopo es una lectora crítica y como tal no deja pasar la oportunidad de argumentar su lectura. Ella le da a su propia perspectiva la función de denuncia sobre el padecimiento de los civiles involucrados en conflictos bélicos. 


\section{EFECTOS DE LA NO GUERRA}

Eva es una lectora de fines del siglo XX o tal vez, al decir de Eric Hobsbawm ${ }^{5}$, del siglo XXI con toda la experiencia de una mujer que ha viajado, que ha vivido en el extranjero, sobrevivido guerras, y veinte años después se encuentra frente a la escritura de otro sobre ella misma. No es el tipo de lectora decimonónica, que llegó a ser considerada peligrosa por alejarse de las costumbres y entrar en el mundo del placer de la lectura.

Desde su presente estático, la narradora hizo un movimiento hacia el pasado y expuso, uno a uno, a todos los personajes, haciendo que sus historias de vida también se congelasen en su enunciado.

$\mathrm{Si}$ a partir del enunciado es posible llegar a la enunciación del sujeto, como propone Benveniste (1989); dicho "sujeto", el narrador, hará que su enunciado no tenga valor en sí mismo, sino que sea un disparador que lleve al acto enunciativo.

Se trata aquí de recuperar el acto de la enunciación no tanto para reproducir el tiempo, el espacio y al sujeto que se manifiesta, lo que es imposible, sino para llegar a través de los elementos del discurso a entender o encontrarle explicación a los porqués del enunciado analizado. Nuevamente, se nos presenta la cuestión de la noción de escritura de Barthes.

Todo enunciado, de alguna manera, nos deja fuera del momento de la enunciación como acto de producción (MAINGUENEAU, 2001); nos aleja topocronológicamente del proceso inmanente del discurso. En sentido contrario, considerar el enunciado nos lleva al estudio trascendente del texto, es decir nos guía al contexto, a lo de fuera del lenguaje

5. Nos referimos a la definición del historiador sobre el siglo XX como "breve", comenzando en 1914 con la primera Guerra Mundial y finalizando en 1991 (HOBSBAWM, 2000, p. 9). 
mismo. Así, como elemento externo a la enunciación tenemos la presencia de los personajes de la historia narrada.

En un primer momento, el narrador del cuento se abstiene de emitir juicios radicales y simplemente describe colores, formas y texturas del entorno de la ciudad de Beira. Como ya mencionamos, Eva Lopo finge coincidir con todo lo que lee, no obstante, su lectura contradice lo narrado en el cuento de forma velada. Esta estrategia se realiza a lo largo de toda la obra, muy especialmente al principio y en el remate final en el que vuelve a insistir sobre la memoria de "os cheiros e as vozes" (JORGE, 1988, p. 259). Sin embargo, va a concederle la importancia de los colores, aunque un poco dispersos al final de la historia.

Dicha coincidencia es una estrategia de la narradora para subestimar la escritura del cuento con la que no estaría de acuerdo. Eva-lectora lo refuta sistemáticamente, porque lee el uso social que se le quiere dar a los hechos ocurridos en Mozambique veinte años antes. Contrariamente, su lectura le otorga a la novela una proyección diferente, yuxtapuesta al cuento pero no simultánea.

Por ejemplo, con respecto al tema de la guerra de la independencia de Mozambique la posición o nociones de escritura de los dos narradores quedaron expuestas. En "Os Gafanhotos", la mención del conflicto es rebajada de "guerra" a una simple "rebelión". El narrador ridiculiza al comandante de la Región Aérea, que "sobraçando uma garrafa” (JORGE, 1988, p. 13) dice:

— Oh! Oh! A guerra! Se não fosse a guerra, mesdames, até a calmaria criaria pedra!" E como o comandante avançasse dizendo isso, o noivo e o capitão não puderam trocar outra palavra. 
Pena! Ainda era muito cedo para se fechar a tarde, ainda era muito cedo para se falar de guerra, que aliás não era guerra, mas apenas uma rebelião de selvagens [...] (JORGE, 1988, p. 13).

De ese mismo comandante se comenta que dominaba algo de inglés por el frecuente contacto que existía entre los oficiales portugueses y los de Sudáfrica. La mención a dicha colaboración e intercambio de prácticas de sometimiento y eliminación de los nativos rebeldes es hecha por el narrador del cuento pero omitida en los comentarios de Eva Lopo. Ella entendía que nadie hablaba con seriedad del tema y percibía que el conflicto era mencionado como "revolta", a la que se le oponía una "contra-revolta"; "banditismo" versus "repressão do banditismo"; "subversão" e contra-subversão" (JORGE, 1988, p.74).

El término "guerra" es entendido por la lectora/ narradora como las varias guerras del padecimento humano "em terra livre, o posto médico, a manutenção, a gerência duma messe" (JORGE, 1988, p. 74). Los efectos secundarios, que el conflicto produjo tan claramente en el alférez, estaban presentes también en el embarazo de las mujeres, en los pequeños empleos mal pagos que ellas podían conseguir, evitando las horas de la canícula, y en los sirvientes. Según Eva, la guerra de las mujeres estaba representada de igual forma en la angustia provocada por la espera de noticias sobre los movilizados hacia el norte. Es palpable en la sugerencia que el capitán Forza Leal le hizo al alférez para que interfiriera con Evita y ella acompañase a su esposa durante la ausencia de ellos: "Aqui a Helena é muito caseira. A sua mulher, ó Luís, é que lhe pode ir lá ajudar a passar a guerra..." (JORGE, 1988, p. 74). 
La guerra era también la experiencia vivida por los distintos extranjeros en Mozambique, ajenos a la misma pero incluidos en las carencias o privaciones:

Uma loja de indiano e de chinês era uma guerra. "Como vai aqui a sua guerra?" — já tinha o noivo perguntado a um paquistanês que vendia pilhas eléctricas de mistura com galochas e canela (JORGE, 1988, p. 74)

Eva leía en esa desvalorización de la palabra una actitud mental extremamente sabia para disfrazar la realidad, que en algún momento tuvieron ante sí, representada en los navíos "engolindo uma fila interminável de soldados verdes" (JORGE, 1988, p. 74-75), que partían del puerto de Beira hacia una acción que no se mencionaba.

Así, y para olvidar lo que estaban viendo mientras cenaban en la mejor marisquería de la ciudad, el capitán Forza Leal propuso ir al cine (ya había comprado las cuatro entradas) para ver una película que hablaba muy mal de Rusia, país comunista considerado archienemigo de Occidente. Se refería al país y al sistema, que habían entrado en África para confundir y rebelar a los anteriormente pasivos colonizados. Antes de la sesión, se dirigieron todos a los toilettes, "e o Luís pediu dinheiro trocado para pagar à menina dos mictórios que não recebia nada pela sua guerra.” (JORGE, 1988, p. 75).

En el cuento, la guerra es el enfrentamiento bélico negado en su gravedad; en lo que hace a la memoria de Eva, significa la transformación forzada de la vida de todos los individuos. Tanto el narrador del cuento como Eva Lopo hacen uso de la ironía y critican al sistema hegemónico por igual. No obstante, ejemplos de la función diferente que cada uno de ellos le da a su discurso son presentados en repetidas oportunidades. En lo que ambos narradores estuvieron de acuerdo fue en la actitud de los medios 
de comunicación ${ }^{6}$ de Beira, a los que ambos creyeron cómplices de los hechos silenciados.

Eva-lectora, en realidad, no está interesada por los nombres que se le pueda dar al conflicto. Trátese de "guerra", "rebelión" o "actos vandálicos", lo que a nuestro personaje de estudio le interesa son los efectos primarios o secundarios en los seres humanos que no provocaron ni decidieron los enfrentamientos.

\section{LEER, LEERSE, ANULAR}

Sólo un narrador omnisciente podría describir los encuentros amorosos de Evita y el alférez en la habitación y el cuarto de baño, que ellos ocupaban en el hotel Stella Maris.

Eva, esta vez, hace caso omiso a los preceptos de Todorov y niega la posibilidad de que hubiese un testigo de la intimidad con su marido. Al mismo tiempo, desestructura al narrador "divino" que todo lo ve y sabe (LEITE)":

Nunca suspeitei de que alguém tivesse sido testemunha de que Evita tivesse tomado banho, partido chávenas, formulado desejos, ou que alguma vez tivesse estado no centro das exclamações. Soberbo! (JORGE, 1988, p. 43-44).

Sistemáticamente, Eva Lopo cuestiona el cuento y se aleja de la historia narrada. Para ello, la lectora se desdobla y se nombra "Evita". El uso de la tercera persona la coloca en

6. Nos referimos a la posición adoptada por los medios de comunicación, que negaban el envenenamiento de nativos como hecho provocado por colonos o militares y responsabilizaban a la propias víctimas de haber robado etanol y confundirlo con vino.

7. Leite cita a Sartre, quien se refiere al punto de vista divino de un narrador que va más allá del tiempo y espacio (2002, p. 26-27). 
un lugar diferente al de la joven que ella considera haber sido. La separa de la novia del alférez, que viajó a Mozambique para casarse en los años 70. Sin embargo, no se leerá solamente como "Evita" o "ela", en otras oportunidades lo hará en primera persona. La lectora se desplaza entre la primera y tercera persona para nombrarse en sus recuerdos.

Esa diferencia tendrá relación, por un lado, con la memoria de sí, que se representa con el pronombre personal "Eu" ("O significado que en lhe dava condensava-se num curto pensamento" (JORGE, 1988, p. 63)). "Eu” se refiere al recuerdo que Eva Lopo tiene y acepta de sí. Lo hace en primera persona que, según afirma Lídia Jorge, es ese punto de vista "del oído que escucha el mundo, el rumor de los otros" (MORÁN BREÑA, 2017), atravesado por el "yo".

También se recuerda como ella misma en la relación prohibida con el periodista Álvaro Sabino del periódico Hinterland: "o jornalista levantava-se quando me via, tomava o à-vontade de quem se familiarizou até ao ponto de poder olhar sem distância para todas as partes do meu corpo" (JORGE, 1988, p. 229). Ellos se mostraban juntos, lo que no era conveniente para el honor familiar ni para el del ejército. $\mathrm{Su}$ relación debía mantenerse en secreto. Ella era la mujer de un alférez portugués y la consigna para las esposas de los militares consistía en permanecer dentro del hotel Stella Maris hasta que ellos regresasen del frente. Pero Evita, mientras su marido estuvo ausente, se mostró por la ciudad, día y noche, con el periodista y sus amigos.

En ese sentido, se trataba de una amistad cómplice y vedada. Pero además, él era un opositor al sistema político, respaldado por el medio de comunicación en el que trabajaba. En primer lugar, el periodista se enfrentó al poder dominante por la investigación que realizara acerca del envenenamiento 
de nativos con metanol y, posteriormente, por la idea sostenida de que los portugueses serían expulsados de Mozambique en un futuro cercano.

Si en el uso de la primera persona Eva Lopo hace referencia a la imagen de sí, con la tercera denotará la forma en que era vista por los demás y, por sobre todo, caracterizada por el narrador. "Evita" era básicamente una joven, cuya historia se relataba en el cuento. También es "Evita" la que fue una noche a la boite Moulin Ronge y se detuvo a observar el ambiente de prostitución reinante tan lejano y desconocido para ella. Sus recuerdos de ese vulgar espacio de diversión no son nítidos, están entrelazados con comentarios del periodista acerca de su propio padre, sus hijos diseminados en varios hogares de distintos puntos de Beira, su trabajo en el diario y la vida que se llevaba en África. Mientras escuchaba el lamento de Álvaro Sabino por haber ocultado hechos delictivos como una forma de prostituirse en el diario o venderse al poder, Eva se pierde en su memoria entre lo que creía ver y el habla ininterrumpida del periodista.

Estos recuerdos son los que impulsan a Eva a rebelarse y son el motivo que la coloca en oposición a la armonía anteriormente reconocida al narrador, presentada en el epígrafe de este trabajo: "Prefere a harmonia? Eu também, é por isso que tanto estimo a paz que se respira na noite d'Os Gafanhotos" (JORGE, 1988, p.69). La falta de mención del periodista del Hinterland en el cuento es leída por Eva Lopo como una provocación. Para ella, ese personaje del bajo mundo fue sin embargo el responsable del desenlace de los hechos vividos en Beira.

Por un lado, el narrador lo consideró simplemente un fotógrafo al que hizo participar en la fiesta de casamiento y con esa función le permitió subir a la terraza y mezclarse con 
los invitados. Por el otro, está el relato de Eva que reconoció haberse involucrado con él y con la investigación de un crimen de lesa humanidad.

Finalmente, ella descalifica el cuento, pidiéndole al narrador que lo deje en suspenso, que no lo prolongue, y que no diga nada más. Ya que lo que queda de ese pasado son murmullos que se van apagando. Aun otorgándole el beneplácito de que en sus palabras se respiraba una paz, que era de su agrado, con la devolución del cuento, lo anula (JORGE, 1988, p. 259).

Eva Lopo lee el cuento “Os Gafanhotos” y esto la lleva a pensar en la joven Evita que ella fue veinte años antes. Una muchacha que viajó a Mozambique a casarse, ilusionada por el reencuentro con su novio pero se encontró con un ser desconocido. La lectura la hace rechazar la forma simple o pacífica de la escritura, porque el cuento no denuncia los hechos más graves de la guerra y se pierde en detalles que agradan.

\section{CONCLUSIONES}

Eva Lopo dista mucho de compararse con los personajes de lectoras decimonónicas. Tampoco representa a alguien que sigue los mandatos patriarcales de obediencia femenina acatados por las mujeres de su época y entorno.

Ella es en parte la lectora independiente que describe Espósito, ya que al leer el cuento "Os Gafanhotos" hace uso de toda su capacidad de análisis de textos y de mundo. Además, es una lectora crítica que conoce el arte de narrar. Partiendo del presupuesto de que la verdad única no existe, ella opta por la ficción por correspondencias. Esta mujer lectora sabe argumentar y defender su posición de testigo de 
los hechos a la vez que discute conceptos de crítica literaria sobre qué es ficción.

En lo que hace a su realidad vivida en Mozambique, ella cree saber mejor que nadie qué es lo que sucedió en el tiempo y espacios mencionados por el narrador del cuento y rescatados por su memoria. Sin embargo, la lectora resalta qué es lo que puede ser narrado "por correspondencias" y qué tiene que permanecer oculto, como la identificación de personajes reales y su relación con el periodista del Hinterland, entre otros. Así como también le da mayor destaque a la ficción, que puede contar la historia con verdades disfrazadas.

Eva es una lectora que discute y pone en evidencia la función social del texto leído. Aunque su postura no sea totalmente contraria a la del narrador, ella centra su mirada en las consecuencias que la colonización y el enfrentamiento bélico tuvieron para la vida de todos los que habitaban tanto en Mozambique como en Portugal.

Ambos son críticos de la forma en que el gobierno central condujo la guerra colonialista en África. Sin embargo, Eva se opone al narrador porque su experiencia le dice que criticar no sirvió para cambiar el rumbo de los acontecimientos. Ella prefiere la exposición de las vulnerabilidades humanas ante los conflictos.

La lectora rechaza la función que el narrador quiso darle a su texto. A pesar de concordar con la crítica a las autoridades representadas por militares y colonos portugueses, que entiende ridiculizados en su lectura, ella cree que eso no es suficiente. Eva necesita darle voz a los que más padecieron y fueron acallados. Los nativos africanos, las mujeres, algunos periódicos y periodistas pueden finalmente verse representados en los discursos directos que recortó la narradora. 
Ella cree que la tercera persona del narrador del cuento no es la más indicada para expresar el quebranto de quien estuvo donde estuvo y vio lo que pasó. Tampoco, para crear un relato vívido de los efectos secundarios sufridos por africanos y portugueses.

A pesar de que la crítica literaria sugirió desconfiar de la primera persona que narra, ella al leer y posteriormente discutir la lectura de los hechos deja esparcida una estela de rumores, con los que se irán armando los verdaderos padecimientos de la guerra.

\section{REFERENCIAS}

BARTHES, Roland. 2003. El grado cero de la escritura. Buenos Aires: Siglo XXI Argentina, 2003.

BENVENISTE, E. Problemas da linguística geral I. Trad. Eduardo Guimarães et ali. Campinas: Pontes, 2005.

BOLLMANN, Stefan. Las mujeres que leen son peligrosas. Madrid: Maeva, 2006.

ESPÓSITO, Fabio. La mujer lectora en la novela argentina de fines del siglo XIX. Espéculo. Revista de estudios literarios. Madrid: Universidad Complutense de Madrid, 2006. Fecha de acceso: 23/02/2021. Disponible en:

[http://www.ucm.es/info/especulo/numero34/mujlecto.html]

HAN, Byung-Chul. La sociedad de la aceleración. La sociedad de la transparencia. Buenos Aires: Herder, 2018, p. 59-65.

HOBSBAWM, E. O novo século. Entrevista a Antonio Polito. São Paulo: Companhia das Letras, 2000.

JORGE, L. A costa dos murmúrios. Lisboa: Publicações Dom Quixote, 1988.

LEITE, L.CH.M. O foco narrativo. São Paulo: Editora Ática, 2002.

MAINGUENEAU, D. Análise de textos de comunicaşão. Trad. Cecilia P. de Souza y Décio Rocha. São Paulo: Cortez, 2001.

MORÁN BREÑA, Carmen. La utopía de la imperfección. Entrevista a Lídia 
Jorge en el diario E1 País. 25/11/2017. Fecha de acceso: 22/02/2021. Disponible en:

[ht tps://elpais.com/cultura/2017/11/24/ actualidad/1511537531_784927.html]

SARLO, Beatriz. Tiempo pasado. Cultura de la memoria y giro subjetivo. Buenos Aires: Siglo XXI Editores Argentina, 2007.

TODOROV, T. Introducción a la literatura fantástica. $4^{a}$. Reimpr. Trad. Silvia Delpy. México D.F.: Ediciones Coyoacán, 2003.

TUSQUETS, Esther. ¿Son peligrosas las mujeres que leen? In: BOLLMANN, Stefan. Las mujeres que leen son peligrosas. Madrid: Maeva, 2006, p. 13-19. 


\section{SOBRE OS AUTORES}

\section{Adriana Esther Suarez}

Possui Graduação em Letras Espanhol/Português (2006) e Licenciatura em Espanhol (2007) pela Universidade de São Paulo (USP). É Mestre em Literatura Hispanoamericana (2011) pela USP. Cursa o Doutorado em Letras com pesquisa em Literatura Portuguesa na Universidad Nacional de Cuyo (UNCuyo) - Mendoza - Argentina, onde atua como professora de Língua e Literatura Portuguesas.

\section{Andréa Correa Paraiso Müller}

Licenciada em Letras pela Universidade Estadual Paulista "Júlio de Mesquita Filho" (UNESP), mestre em Letras pela mesma instituição e doutora em Teoria e História Literária pela Universidade Estadual de Campinas (UNICAMP). Desde 1999, é professora efetiva de Língua e Literatura Francesa na Universidade Estadual de Ponta Grossa (UEPG), onde desenvolve pesquisas sobre o gênero romance.

\section{Cibeli Grochoski}

Graduada em História pela Universidade Estadual do Centro-Oeste (2017), mestre em História pelo Programa de Pós-Graduação em História da Universidade Estadual do Centro-Oeste (2020). Atualmente é doutoranda em História pela Universidade Federal do Paraná. 


\section{Daiane da Silva Lourenço}

Graduada em Letras (Português/Inglês) pela FECILCAM. Mestre em Letras, com ênfase em estudos literários, pela Universidade Estadual de Maringá. Doutora em Letras pela Universidade Estadual de Maringá na área de estudos literários com foco em literaturas em língua inglesa. Realizou estágio doutoral como bolsista PDSE/CAPES na University of Saskatchewan, sob supervisão da professora Dra. Kathleen James-Cavan. Atualmente é professora adjunta da Universidade Tecnológica Federal do Paraná, câmpus Francisco Beltrão, no Departamento de Humanidades.

\section{Katia Aparecida da Silva Olliveira}

É professora de Literaturas da Espanha na Universidade Federal de Alfenas (UNIFAL-MG). É doutora em Letras pela Universidade Estadual Paulista Júlio de Mesquita Filho (UNESP), com período sanduíche na Universitat de Barcelona, e mestre em Letras -Literatura Espanhola pela Universidade de São Paulo (USP), onde cursou também a graduação.

\section{Larissa de Cássia Antunes Ribeiro}

Graduada em Letras - Português/Francês pela Universidade Estadual de Ponta Grossa - UEPG; Mestre e Doutora em Estudos Literários pela UEPG e Universidade Estadual do Paraná - UFPR, respectivamente. Atua no Ensino de Língua Francesa no Centro de Línguas da Universidade Estadual do Centro Oeste - UNICENTRO - Irati/PR e ministra aulas de Estágio em Língua Estrangeira na UEPG. 


\section{Midori Nancy Arasaki Chang}

Cursou Licenciatura em Letras, Português e Espanhol, na Universidade Estadual de Ponta Grossa (UEPG). É Mestre em Estudos da Linguagem (2021) pela mesma Universidade (UEPG).

\section{René Aldo Vijarra}

Licenciado em Letras Modernas pela Universidad Nacional de Córdoba (UNC). É Doutor em Estudos de Gênero pela UNC. Atualmente é Professor Regular Titular da Cátedra de Literatura Espanhola I da Facultad de Filosofía y Humanidades de la UNC. Pesquisa questões de gênero, identidade, corpo e afetos no discurso feminino do Século de Ouro espanhol.

\section{Rosangela Schardong}

Graduada em Letras, Português e Espanhol pela Universidade Federal de Santa Catarina (UFSC), com mestrado e doutorado em Letras, pela Universidade de São Paulo (USP). É Professora Associada da Universidade Estadual de Ponta Grossa (UEPG), atuando na graduação em Letras Espanhol e no Programa de Pós Graduação em Estudos da Linguagem. Coordena o projeto de pesquisa continuada Poética dos gêneros e da tradução nas letras e artes em língua espanhola. 
Texta e Contexto

EDITORA E LIVRARIA

(42) 988834226

textoecontexto.editora@gmail.com www.textoecontextoeditora.com.br 